\author{
UNIVERSIDADE DE SÃO PAULO \\ ESCOLA DE ENGENHARIA DE SÃO CARLOS \\ DEPARTAMENTO DE ENGENHARIA DE TRANSPORTES
}

\title{
ANÁLISE DA INFLUÊNCIA E CARACTERÍSTICAS DAS VIAS NO NÚMERO E NA SEVERIDADE DOS ACIDENTES: ESTUDO DE CASO NA AUTOESTRADA GRAJAÚ-JACAREPAGUÁ
}





\section{ANÁLISE DA INFLUÊNCIA E CARACTERÍSTICAS DAS VIAS NO NÚMERO E NA SEVERIDADE DOS ACIDENTES: ESTUDO DE CASO NA AUTOESTRADA GRAJAÚ-JACAREPAGUÁ}

Bruno Alexandre Brandimarte Leal

Dissertação apresentada à Escola de Engenharia de São Carlos da Universidade de São Paulo, como parte dos requisitos para obtenção do título de mestre em ciências - Programa de Pós-graduação em Engenharia de Transportes.

Área de concentração: Infraestrutura de Transportes.

Orientador: Professor Titular José Leomar Fernandes Júnior.

São Carlos 
AUTORIZO A REPRODUÇÃO TOTAL OU PARCIAL DESTE TRABALHO, POR QUALQUER MEIO CONVENCIONAL OU ELETRÔNICO, PARA FINS DE ESTUDO E PESQUISA, DESDE QUE CITADA A FONTE.

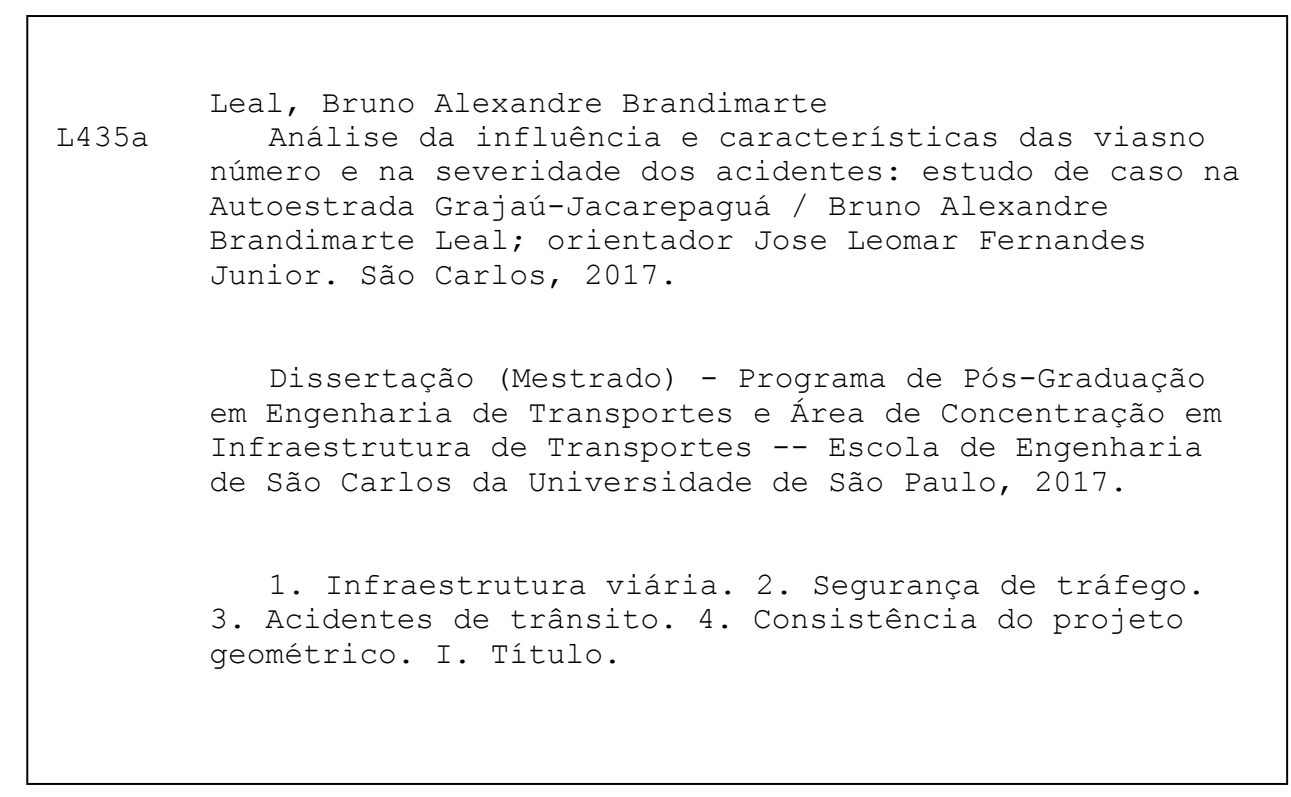




\section{AGRADECIMENTOS}

Primeiramente, agradeço à minha família, pelo apoio incondicional. Ao meu pai, Walter, e à minha mãe, Raquel, por todo o carinho e suporte. Ao meu irmão, André, pelas discussões que tivemos a fim de fomentar as ideias. À minha avó, Rosa, por me chamar para ficar em sua casa todas as vezes em que precisei de um lugar quieto para estudo. Aos meus parentes Ruth, Ercole, Gina, Thiago, Giovanni e Giovanna pelo apoio e motivação.

Ao professor José Leomar Fernandes Júnior, orientador desta dissertação, pessoa por quem cultivo grande respeito e admiração, pela confiança, pela amizade e principalmente pela paciência.

À professora Sandra Oda, por toda atenção e carinho e pelo importante estímulo em diversas etapas do desenvolvimento deste trabalho, sempre se mostrando disponível para a retirada de várias dúvidas.

Aos professores, funcionários e alunos do Departamento de Engenharia de Transportes da Escola de Engenharia de São Carlos da Universidade de São Paulo, agradeço os conhecimentos transmitidos, em especial à dra. Ana Paula Camargo Larocca e ao dr. Paulo Cesar Lima Segantine, pelas valiosas observações em minha etapa de qualificação. À Elaine Ribeiro, que além de me atualizar sobre todas as datas de inscrições, se mostrou uma grande amiga que levarei para sempre.

Ao CNPq, pelo suporte financeiro. À CET-Rio, pelo fornecimento de dados de acidentes, e à Prefeitura do Rio de Janeiro por disponibilizar os levantamentos topográficos, sem os quais não haveria viabilidade de fazer a análise do trabalho. À UFRJ e à Uerj por me oferecerem todo o meu embasamento técnico-profissional e senso crítico que utilizarei por toda a minha vida. À UFRGS, em especial ao professor Daniel Garcia, e a toda equipe que disponibilizaram o software Saepro, que sem o qual não haveria viabilidade na pesquisa. o Ao Rio Ônibus, empresa que tive o primeiro contato com a Engenharia de Transportes, em especial aos meus chefes Paula e Marcelo, que me permitiram muitas e muitas folgas para que eu conseguisse concluir este trabalho, e aos funcionários e agregados Taiana, Aline, Natalia, Miguel, Diego, Artur, Felipe, Rodrigo, Giovani e Luciana. 


\section{RESUMO}

LEAL, B. A. B. Análise da influência e características das vias no número e na severidade dos acidentes: um estudo de caso na Autoestrada Grajaú-Jacarepaguá. Dissertação (Mestrado) - Escola de Engenharia de São Carlos da Universidade de São Paulo. São Paulo: 2017.

O objetivo deste trabalho é analisar a relação de características das vias com os acidentes de trânsito. A principal motivação para o desenvolvimento deste estudo está na ampla variedade de características que podem ter influência nos acidentes e na complexidade da relação entre elas, que pode tornar a análise distinta em cada caso. As vantagens decorrentes da adoção de ações baseadas no gerenciamento de riscos e no tratamento preventivo da segurança viária priorizam atuações sobre veículos e, em especial, sobre o esquema viário como alternativa viável para reduzir o peso do fator humano nos acidentes. Para isso foi elaborado um longo referencial teórico, enumerando potenciais características e as relacionando com acidentes, ressaltando a importância de avaliar e tratar aspectos concatenados ao veículo e à via, com o intuito de conseguir uma análise mais eficaz nas condições de segurança e contribuindo nas áreas acadêmica e profissional fornecendo dados e informações para ajudar na identificação e escolhas de características que mais influenciem a segurança. Também foi desenvolvido um estudo de caso, considerando a Autoestrada Grajaú-Jacarepaguá (Avenida Menezes Cortes), localizada na cidade do Rio de Janeiro. A partir de dois bancos de dados de acidentes, fornecidos pela Companhia de Engenharia de Tráfego do Rio de Janeiro (CETRio) e uma investigação de campo realizada na autoestrada, foram identificadas relações dos acidentes com as características viárias. Concluiu-se que as características das vias têm grande relevância sobre os acidentes ocorridos. Os resultados indicam que a consistência geométrica está relacionada aos acidentes de trânsito, porém ainda não existe um modelo de previsão que ajude a entender tal comportamento. De forma geral, as atividades de reconstrução e manutenção da via também dão apoio nas questões de segurança de tráfego. Apesar das limitações, espera-se que o estudo apresentado nesse projeto sirva como referência para futuras intervenções e melhorias das vias.

Palavras-chave: Infraestrutura viária; Segurança de tráfego; Acidentes de trânsito; Consistência do projeto geométrico. 


\begin{abstract}
LEAL, B. A. B. Analysis of the influence of roads characteristics on the number and severity of accidents: case study on the Grajaú-Jacarepaguá Highway. Dissertation (Masters) - São Carlos Engineering School of São Paulo University. São Paulo: 2017

This study aims at analyzing a relationship of influence between the accidents and the road characteristics. The main study motivation is on the wide variety of characteristics that may influence the accidents, which can make the analysis distinct in each case. The advantages from the adoption of actions based on road safety risk management and the preventive treatment prioritize interventions on vehicles and, in particular, on the road system as a viable alternative to reduce the role of the human factor in accidents. For this, a long theoretical framework was developed, enumerating potential characteristics and relating them to accidents, emphasizing the importance of evaluating e treating related to the vehicle and to the highway to achieve a more effective analysis in safety conditions and contributing in the academic and professional areas providing data and information to help in the identification and selection of characteristics that influence the safety. Also, a case study was prepared, considering the Grajaú-Jacarepaguá Highway (Menezes Cortes Avenue), located in Rio de Janeiro. Based on two accidents databases provided by Agency of Engineering of Traffic of Rio de Janeiro (CET-Rio) and a highway field investigation, some relationships of accidents with roads characteristics were identified. It can be concluded that roads characteristics have great relevance on the occurred accidents. The results indicate that geometric consistency have a relationship with traffic accidents, however there isn't still a predictive model to support the understanding of this behavior. In general, the reconstruction and maintenance activities also support traffic safety issues. Despite the limitations, it is expected that the presented study in this project will serve as a reference for the future interventions and improvements of roads.
\end{abstract}




\section{LISTA DE FIGURAS}

Figura 1.1: Evolução do Número de óbitos em acidentes por região do Brasil entre 2002 e

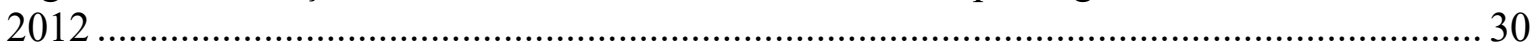

Figura 1.2: Participação das regiões no número de óbitos em acidentes em 2012 .............. 30

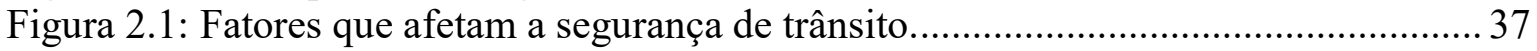

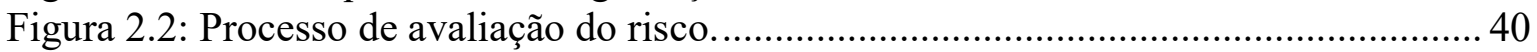

Figura 2.3: Número de mortos em acidentes de trânsito para cada milhão de habitantes na

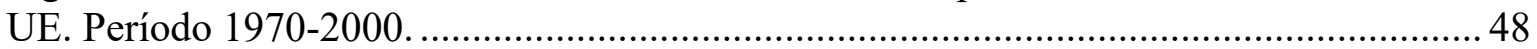

Figura 3.1: Estrutura conceitual de vinculação entre meio ambiente construído para

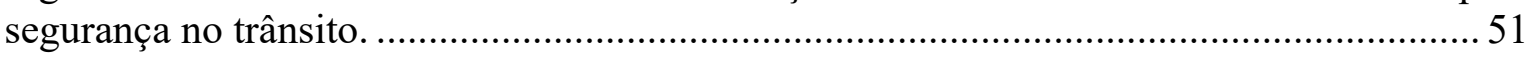

Figura 3.2: Locais problemáticos de interação traçado/entorno complexa. ....................... 53

Figura 3.3: Locais problemáticos em função da seção transversal...................................... 56

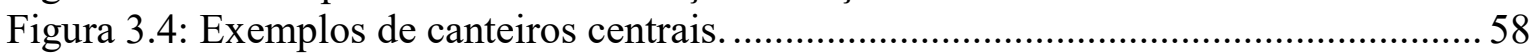

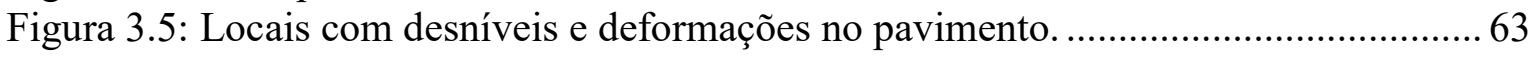

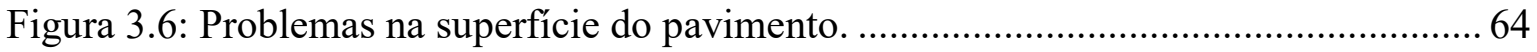

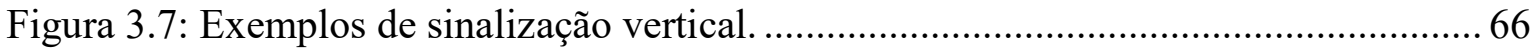

Figura 3.8: Exemplos de marcações transversais. Fonte: Adaptado de DNIT (2010b) ...... 68

Figura 3.9: Exemplos de marcas longitudinais. Fonte: Adaptado de DNIT (2010b) ..........69 69

Figura 3.10: Exemplos de marcas de canalização. ........................................................... 70

Figura 3.11: Exemplo de marca de delimitação de proibição de estacionamento................ 70

Figura 3.12: Exemplos marcas de inscrições no pavimento.......................................... 70

Figura 3.13: Tachões de LED alimentados com energia solar........................................ 72

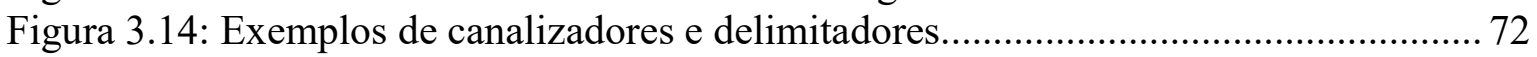

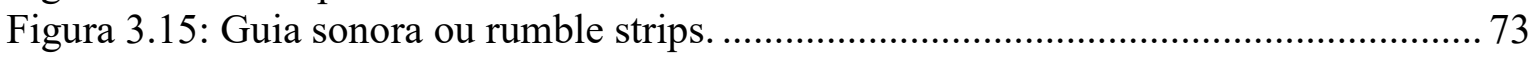

Figura 3.16: Efeito dos alinhamentos das aproximações nos índices de acidentes............. 74

Figura 3.17: Pontos de conflito e possível medida corretiva......................................... 75

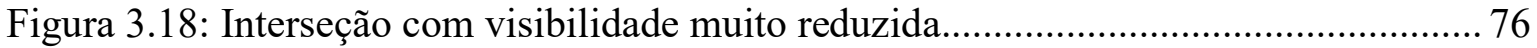

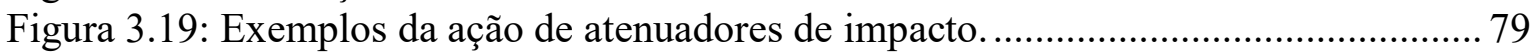

Figura 3.20: Efeito do spray em diferentes pavimentos. ................................................. 81

Figura 3.21: Acidentalidade horária em vias de Valência, Espanha. Ano de 2000............. 81

Figura 3.22: Exemplos de travessias de pedestres superiores e inferiores, respectivamente.

Figura 3.23: Local com excesso de elementos publicitários antes e depois da Lei Cidade

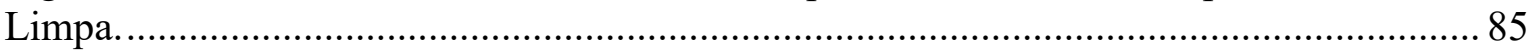

Figura 3.24: Exemplo de estacionamento inapropriado de veículo.................................. 87

Figura 3.25: Exemplos de acidentes causados por congestionamentos em estradas do estado

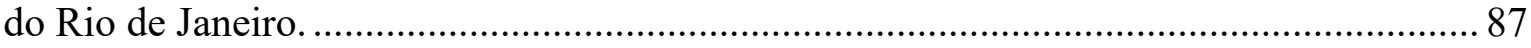

Figura 3.26: Relação entre a variação da velocidade e a variação dos acidentes................. 90

Figura 3.27: Problemas originados pela falta de controle da vegetação. ............................ 92

Figura 4.1: Critérios desejáveis para orientar a escolha dos raios de curvas sucessivas... 100

Figura 4.2: Condições de aceleração e desaceleração entre curvas sucessivas.................. 101

Figura 5.1: Pontos críticos dos acidentes da Avenida Menezes Cortes. ............................ 115

Figura 6.1: (a) Seção transversal da Estrada Grajaú-Jacarepaguá (esquerda) e (b) vista de parte de seu traçado (direita) na época de sua construção................................................. 117

Figura 6.2: (a) Vista da Estrada Grajaú-Jacarepaguá (esquerda) e (b) vista de parte de seu

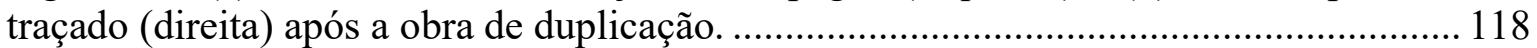

Figura 6.3: Traçado da Avenida Menezes Cortes............................................................. 119 Figura 6.4: Mapa do Parque Nacional da Tijuca e localização da Avenida Menezes Cortes. 
Figura 6.5: Mapa do acesso e da saída da Avenida Menezes Cortes no bairro do Grajaú. 121 Figura 6.6: Fotos do acesso e da saída da Avenida Menezes Cortes no bairro do Grajaú. 121 Figura 6.7: Acesso e saída da Avenida Menezes Cortes no Bairro de Jacarepaguá........... 121 Figura 6.8: Acesso e saída da Avenida Menezes Cortes no bairro de Jacarepaguá. .......... 122 Figura 6.9: Localização dos pontos de embarque e desembarque da Avenida Menezes

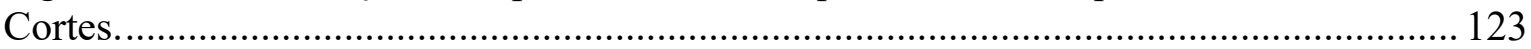

Figura 6.10: Localização das passarelas da Avenida Menezes Cortes............................. 124

Figura 6.11: Fotos das passarelas da Avenida Menezes Cortes. ..................................... 124

Figura 6.12: Seção transversal com dois tipos de barreiras de contenção.......................... 125

Figura 6.13: Seção transversal com canteiro central gramado....................................... 125

Figura 6.14: Seção transversal com guard rail metálico e barreira de contenção de concreto.

Figura 6.15: Seção transversal com barreira de contenção de concreto................................ 126

Figura 6.16: Mapa esquemático com as curvas da Avenida Menezes Cortes.................... 128

Figura 6.17: Trecho sem SMA (Stone Matrix Asphalt)................................................. 129

Figura 6.18: Trecho com SMA (Stone Matrix Asphalt)................................................... 130

Figura 6.19: Lava a jato no entorno da Avenida Menezes Cortes..................................... 130

Figura 6.20: Placa de alerta no início da via no bairro do Grajaú. ................................... 131

Figura 6.21: Primeira página do relatório de classificação pelo $\mathrm{CS}_{\mathrm{I}}, \mathrm{CS}_{\mathrm{II}}, \mathrm{ICG}_{\mathrm{km}}, \mathrm{ICG}_{\text {trecho }}$. 133

Figura 6.22: Segunda página do relatório de classificação pelo $\mathrm{CS}_{\mathrm{I}}, \mathrm{CS}_{\mathrm{II}}, \mathrm{ICG}_{\mathrm{km}}, \mathrm{ICG}_{\text {trecho }}$. 134

Figura 6.23: Porcentagens de acidentes por trecho. ................................................... 139

Figura 6.24: Localização dos acidentes de trânsito por ano nos trechos KM 1 e KM 2... 139 Figura 6.25: Localização dos acidentes de trânsito por ano nos trechos KM3, KM4, KM 5 e

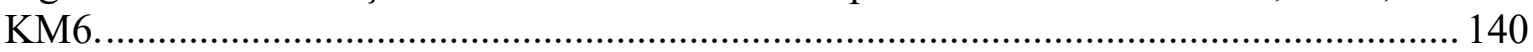

Figura 6.26: Localização dos acidentes de trânsito por ano nos trechos KM 7 e KM 8... 141

Figura 6.27: Porcentagem dos acidentes em função do tipo. .......................................... 142

Figura 6.28: Localização dos acidentes de trânsito por tipo nos trechos KM 1, KM 2, KM3

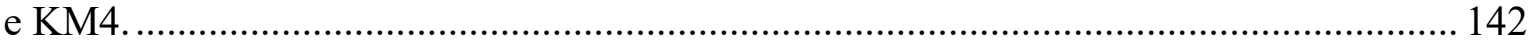

Figura 6.29: Localização dos acidentes de trânsito por tipo nos trechos KM5, KM6, KM 7 e

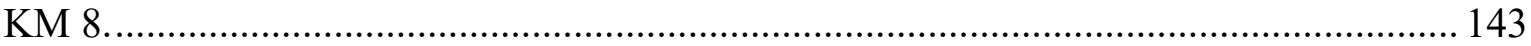

Figura 6.30: Porcentagem dos acidentes em função das horas do dia.............................. 144

Figura 6.31: Porcentagem dos acidentes em função dos dias da semana........................... 144

Figura 6.32: Porcentagem dos acidentes em função dos meses. ........................................ 145

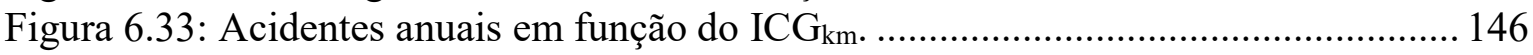

Figura 6.34: Marcas nas barreiras de concreto e danos nas barreiras longitudinais de

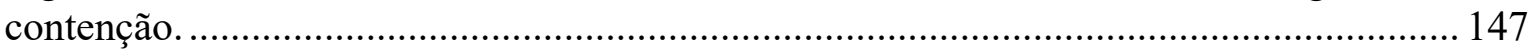

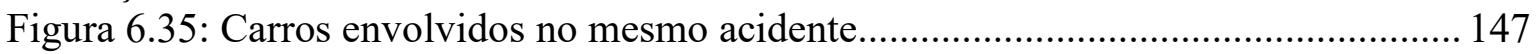

Figura 6.36: Problemas com as barreiras de contenção...................................................... 148

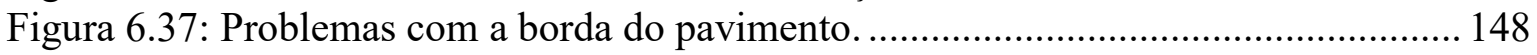

Figura 6.38: Placa de atenção localizada no bairro do Grajaú. .......................................... 149

Figura 6.39: Placa de atenção localizada no bairro de Jacarepaguá.................................. 149

Figura 6.40: Pista da Avenida Menezes Cortes sem pintura de divisão de faixas. ............ 150

Figura 6.41: Acidentes próximos aos retornos físicos................................................... 150

Figura 6.42: Automóveis que utilizam o retorno como estacionamento........................... 151

Figura 6.43: Localização e problemas de visibilidade no retorno próximo ao Hospital... 151

Figura 6.44: Acidentes no acesso da Avenida Menezes Cortes. ...................................... 152

Figura 6.45: Entroncamento da Avenida Menezes Cortes com a rua José do Patrocínio. 152

Figura 6.46: Relação da precipitação mensal com o número de acidentes. ....................... 155 
Figura 6.47: Relação do número de dias com precipitação maior que $1 \mathrm{~mm}$ com o número

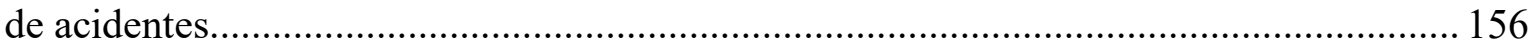

Figura 6.48: Problemas de projeto com dispositivos de drenagem............................... 157

Figura 6.49: Lixo espalhado que não foi coletado próximo ao dispositivo de drenagem. 157

Figura 6.50: Casos de atropelamento (pontos verdes) próximos à passarela (traço vermelho)

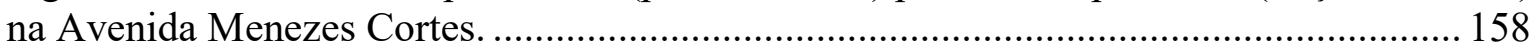

Figura 6.51: Outdoors na Avenida Menezes Cortes....................................................... 158

Figura 6.52: Letreiros de comércios próximos à Avenida Menezes Cortes...................... 159

Figura 6.53: Estacionamento irregular ao longo da Avenida Menezes Cortes. ................ 159

Figura 6.54: Número de acidentes ao longo das horas do dia e marcação das horas-pico.160

Figura 6.55: Visibilidade da via comprometida pela vegetação........................................ 161

Figura 6.56: Placa escondida pela vegetação na Avenida Menezes Cortes. ...................... 161

Figura 6.57: Calçada tomada por vegetação................................................................... 161

Figura 6.58: Visibilidade e drenagem da via comprometidas pela vegetação.................... 162 


\section{LISTA DE TABELAS}

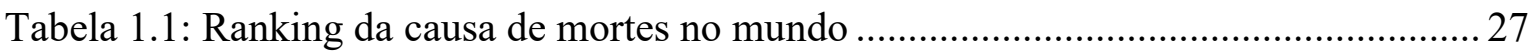

Tabela 1.2: Ranking dos países com maior número de óbitos em 2009 e em 2013 ............ 28

Tabela 1.3: Número de óbitos em acidentes no Brasil entre 2002 e 2012 ......................... 29

Tabela 1.4: Número de óbitos em acidentes de trânsito nas capitais brasileiras entre $2002 \mathrm{e}$

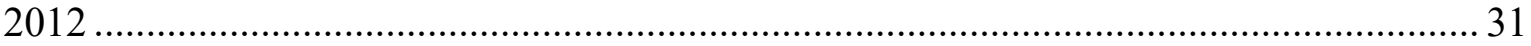

Tabela 2.1: Medidas de exposição ao risco no trânsito ......................................................... 42

Tabela 2.2: Elementos do processo de percepção do risco segundo os prejulgamentos

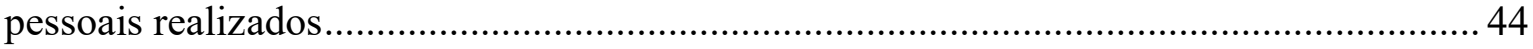

Tabela 2.3 Tendências intuitivas na percepção do risco ................................................... 45

Tabela 2.4: Características da percepção do risco segundo o tipo de avaliador................... 46

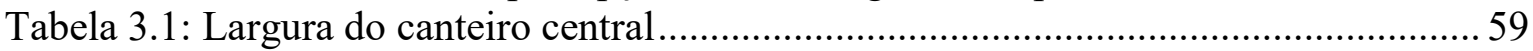

Tabela 3.2: Impacto nos acidentes das faixas para os giros em interseções....................... 75

Tabela 3.3: Taxas de acidentes em vias urbanas em função do nível de controle de acessos

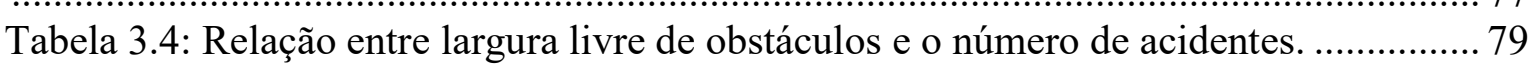

Tabela 3.5: Relação entre a velocidade do motorista e o ângulo de visão. ........................... 88

Tabela 4.1: Modelos para estimativa do coeficiente de atrito adotado e efetivo na Alemanha

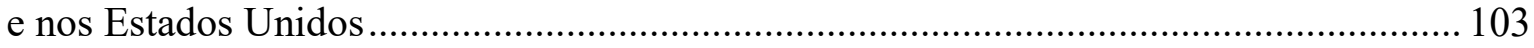

Tabela 4.2: Classificação do Módulo de Segurança para Projetos Geométricos. .............. 104

Tabela 4.3: Pesos dos níveis de classificação dos critérios de segurança I e II.................. 106

Tabela 4.4: Intervalos de classificação das características avaliadas. .............................. 108

Tabela 4.5: Intervalos de classificação do ICG. ............................................................... 108

Tabela 5.1: Ranking dos logradouros com maior número absoluto de acidentes com vítimas no ano de 2012 até junho no município do Rio de Janeiro.............................................. 114

Tabela 6.1: Distâncias entre Jacarepaguá e Centro do Rio de Janeiro em 1950 ............... 118

Tabela 6.2: Contagens de veículos por categoria .............................................................. 122

Tabela 6.3: Relação de linhas que percorrem a Avenida Menezes Cortes........................ 123

Tabela 6.4:Tabela de curvas da Avenida Menezes Cortes ............................................. 127

Tabela 6.5: Classificação da Avenida Menezes Cortes pelo critério de segurança I ......... 135

Tabela 6.6: Classificação da Avenida Menezes Cortes pelo critério de segurança II ........ 135

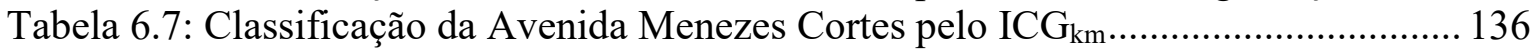

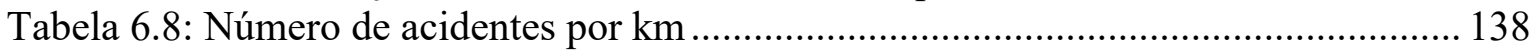

Tabela 6.9: Número de acidentes por tipo distribuídos por trecho.................................. 141

Tabela 6.10: Classificação por quilômetro ................................................................. 145

Tabela 6.11: Registros pluviométricos da estação Estrada Grajaú-Jacarepaguá para o período

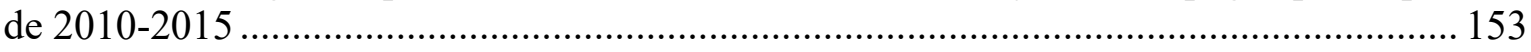

Tabela 6.12: Dias com precipitação maior que $1 \mathrm{~mm}$ em cada estação ............................. 153

Tabela 6.13: Número de acidentes da Avenida Menezes Cortes por mês.......................... 154 


\section{LISTA DE SIGLAS, ABREVIATURAS E SÍMBOLOS}

AADT

AASHO

AASHTO

$\mathrm{AC}$

APK

ASF

BIM

BRAT

BRICS

CEPIS

CETRA

CET-Rio

CFIA

CNT

$\mathrm{CS}_{\mathrm{i}}$

$\mathrm{CS}_{\mathrm{iLE}}$

$\mathrm{CS}_{\mathrm{iLD}}$

$\mathrm{CS}_{\mathrm{C}}$

$\mathrm{CS}_{\text {I }}$

$\mathrm{CS}_{\text {II }}$

CONTRAN

$\mathrm{D}$

DC

DCT

DNER

DNIT

$\mathrm{E}(\mathrm{PC})$

$\mathrm{E}(\mathrm{PT})$

FHWA

FTP
Volume Média Diário Annual (Annual Average Daily Traffic)

American Association of state Highway Officials

American Association of State Highway and Transportation Officials

Ângulo Central da Curva

Acidentes por Quilômetro

Automotive Safety Foundation

Building Information Modeling

Boletim de Registro de Acidente de Trânsito

Brasil, Rússia, Índia, China e África do Sul

Centro Panamericano de Ingeniería Sanitária y Ciencias del Ambiente

Centro de Investigación y Desarrollo del Transporte

Companhia de Engenharia de Tráfego do Rio de janeiro

Canadian Food Inspection Agency

Confederação Nacional dos Transportes

Critério de segurança i do intervalo de $100 \mathrm{~m}$

Critério de segurança i do intervalo de $100 \mathrm{~m}$ do lado esquerdo da via

Critério de segurança i do intervalo de $100 \mathrm{~m}$ do lado direito da via

Critério de segurança composto do intervalo de $100 \mathrm{~m}$

Critério de segurança I do intervalo de $100 \mathrm{~m}$

Critério de segurança II do intervalo de $100 \mathrm{~m}$

Conselho Nacional de Trânsito

Desenvolvimento da Curva

Taxa Angular de Curvatura

Dispositivos de Controle de Tráfego

Departamento Nacional de Estradas de Rodagem

Departamento Nacional de Infraestrutura de Transportes

Estaca do Ponto de Curva

Estaca do Ponto de Tangente

Federal Highway Administration

Faixa de Travessia de Pedestres 
GAO

GBM

GPS

GRSP

GSV

GUI

I

$\mathrm{ICG}_{\mathrm{km}}$

$\mathrm{ICG}_{\text {trecho }}$

IHSDM

IMT

ISP

$\mathrm{KPH}$

LBO

LFO-1

LFO-2

LFO-3

LFO-4

LMS-1

LMS-2

LRE

LW

MAC

MCC

MCI

MFR

NCHRP

OCDE

PARE

PDTU

PMV

PRPM

R

SAEPRO
General Accounting Office

Grupamento de Bombeiro Militar

Global Positioning System

Global Road Safety Partnership

Gerenciamento da Segurança Viária

Graphical User Interface

Declividade

Índice de Consistência Geométrica por Quilômetro

Índice de Consistência Geométrica por Trecho

Interactive Highway Safety Design Model

Instituto Mexicano del Transporte

Instituto de Segurança Pública

Quilômetros Percorridos Habilitados

Linha de Bordo

Linha Simples Contínua

Linha Simples Seccionada

Linha Dupla Contínua

Linha Dupla Contínua/Seccionada

Linha Simples Contínua

Linha Simples Seccionada

Linha de Retenção

Largura da Pista

Marcação de Área de Conflito

Marcação de Cruzamento Rodociloviário

Marcação de Ciclofaixa ao longo da via

Linha Dupla Seccionada

National Cooperative Highway Research Program

Organização de Cooperação e de Desenvolvimento Econômico

Programa de Redução dos Acidentes de Trânsito

Plano Diretor de Transporte Urbano

Painéis de Mensagens Variáveis

Permanent Raised Pavement Marker

Raio da Curva

Sistema Avançado para Estudo de Projetos Viários 
SMA

SMTR

SW

$\mathrm{T}$

TRB

TXDOT

UF

$\mathrm{V}_{85}$

$\mathrm{V}_{85 \mathrm{e}}$

$\mathrm{V}_{85 \mathrm{p}}$

$\mathrm{V}_{\mathrm{d}}$

WHO
Stone Matrix Asphalt

Secretaria Municipal de Transportes do Rio de Janeiro

Largura do Acostamento

Tangente Externa da Curva

Transportation Research Board

Texas Department of Transportation

Unidade da Federação

Velocidade Operacional

Velocidade Operacional Efetiva

Velocidade Operacional Potencial

Velocidade de Projeto

Organização Mundial da Saúde (World Health Organization) 


\section{SUMÁRIO}

1. INTRODUÇÃO .......................................................................................................... 27

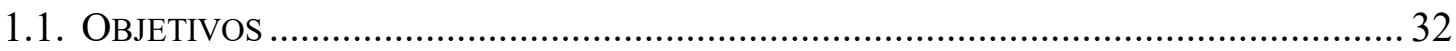

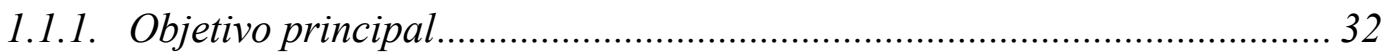

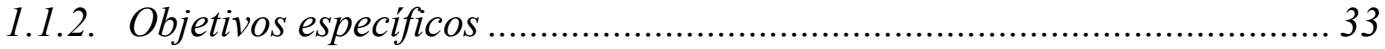

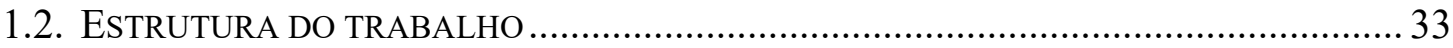

2. SEGURANÇA VIÁRIA E ACIDENTES DE TRÂNSITO.........................................36

2.1. FATORES CONTRIBUINTES NOS ACIDENTES DE TRÂNSITO ……………………........36

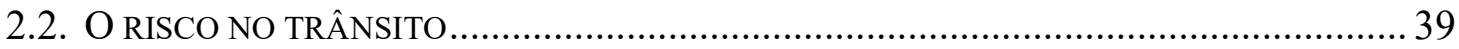

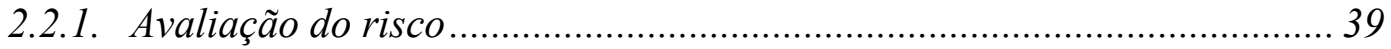

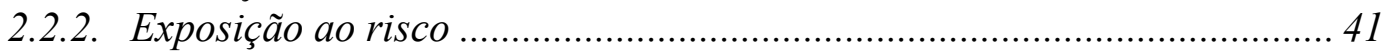

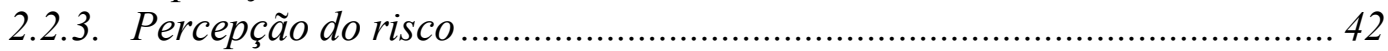

2.3. ABORDAGEM SOBRE OS ACIDENTES DE TRÂNSITO ………...................................... 47

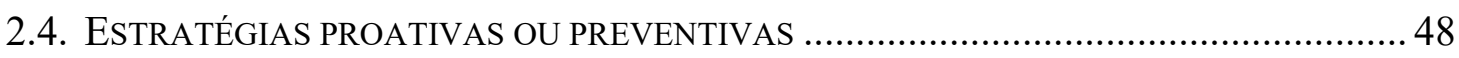

3. RELAÇÃO DAS CARACTERÍSTICAS DA VIA E A SEGURANÇA DO

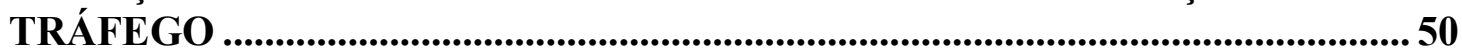

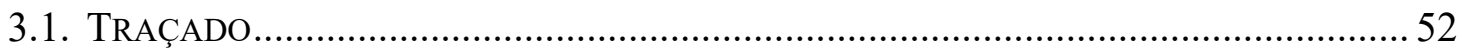

3.1.1. Alinhamento Horizontal ................................................................... 53

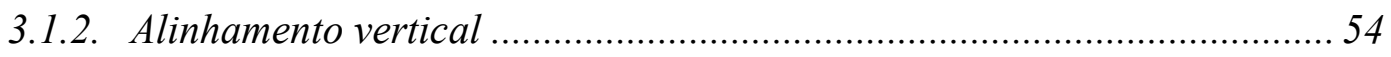

3.1.3. Integração entre alinhamentos verticais e horizontais ............................. 55

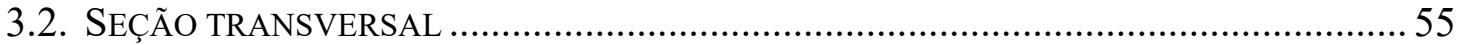

3.2.1. Faixas 56

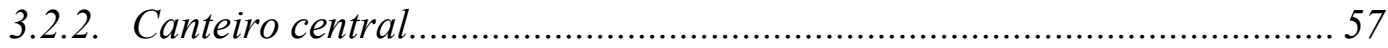

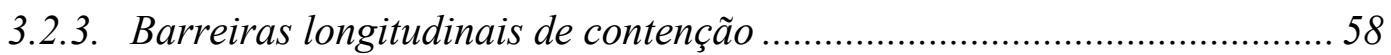

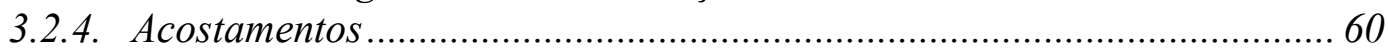

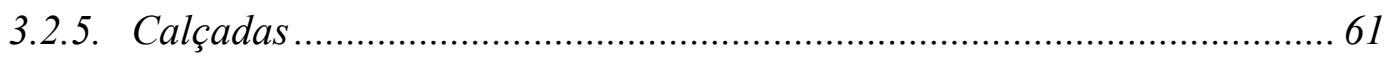

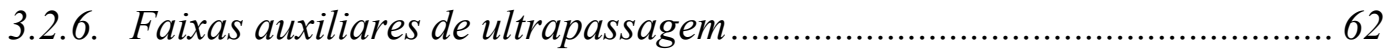

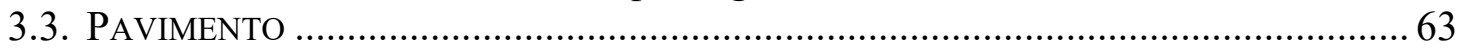

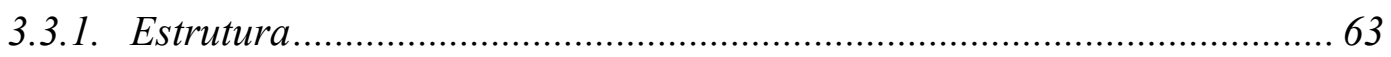

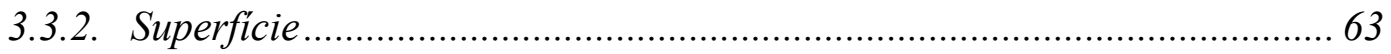

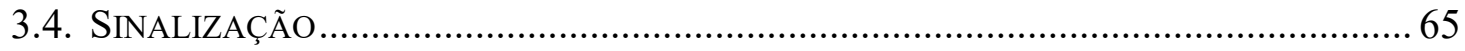

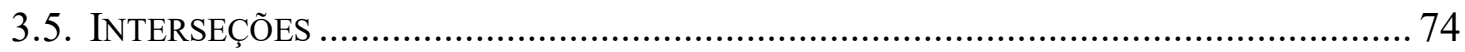

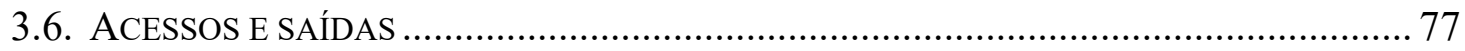

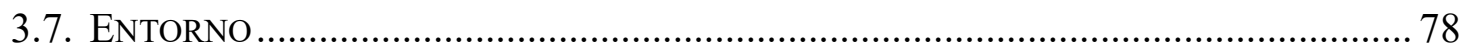

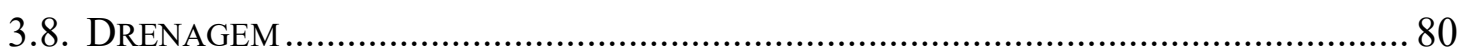

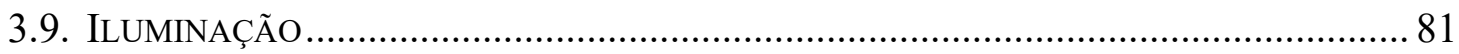

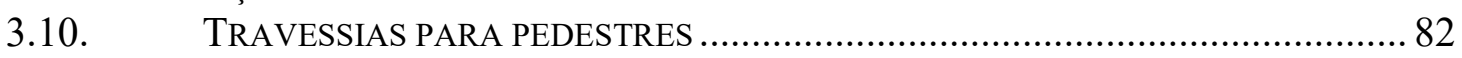

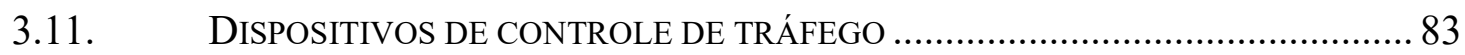

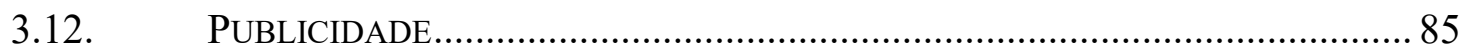

3.13. ESTACIONAMENTO ………………………………………………. 86

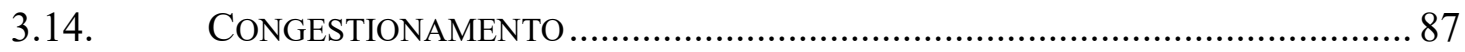

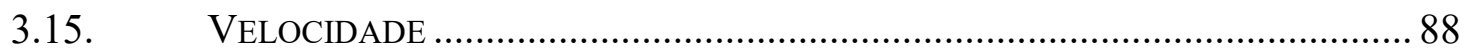

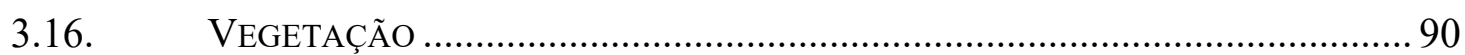

4. CONSISTÊNCIA GEOMÉTRICA ….................................................................93

4.1. Modelos De ESTIMATIVA DA VELOCIDADE OPERACIONAL.....................................93

4.1.1. Modelo de Lamm et al. (1990)............................................................ 94 


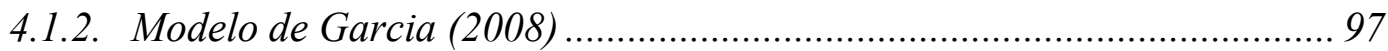

4.2. ClassificAÇÃO dOS SEGMENTOS DE ACORDO COM SUA CONSISTÊNCIA ................. 98

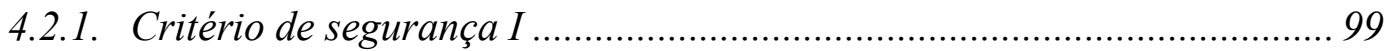

4.2.2. Critério de segurança II ....................................................................... 100

4.2.3. Critério de segurança III..................................................................... 103

4.2.4. Classificação dos projetos segundo os critérios I, II e III ...................... 104

4.3. ClaSSIFICAÇÃO DOS PROJETOS ATRAVÉS DO ICG .............................................. 105

4.3.1. Pesos dos critérios de segurança I e II para a classificação ................... 105

4.3.2. Cálculo do critério de segurança composto $\left(C S_{c}\right)$.................................. 106

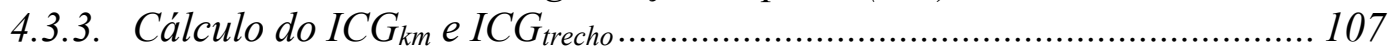

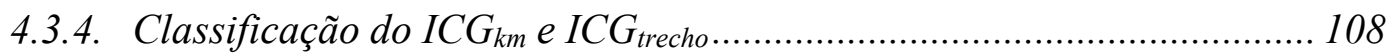

4.4. FERRAMENTAS DE ANÁLISE DO PROJETO GEOMÉTRICO ...................................... 109

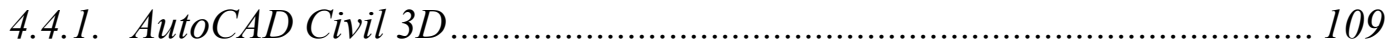

4.4.2. Interactive Highway Safety Design Model - IHSDM............................ 109

4.4.3. Sistema Avançado para Estudos e Projetos Viários - Saepro ................ 110

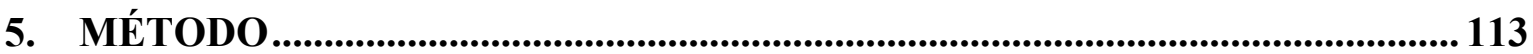

5.1. CARACTERÍSTICAS DAS VIAS E A RELAÇÃO COM OS ACIDENTES ............................ 114

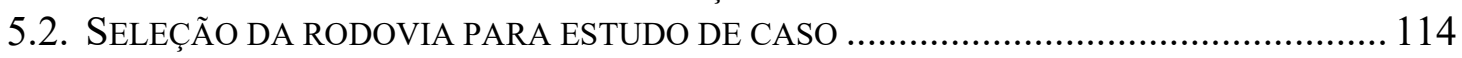

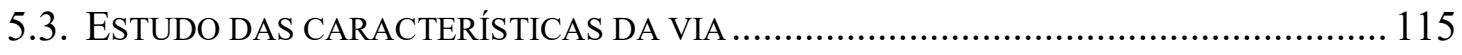

5.4. COLETA E TRATAMENTO DOS DADOS DE ACIDENTES DE TRÂNSITO ....................... 115

5.5. RELAÇÃO DOS ACIDENTES NA RODOVIA COM O ESTUDO DAS CARACTERÍSTICAS .. 116

6. ESTUDO DE CASO: AVENIDA MENEZES CORTES .................................... 117

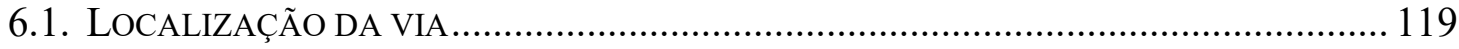

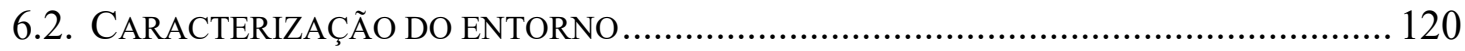

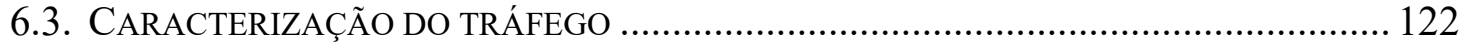

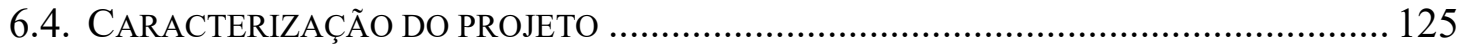

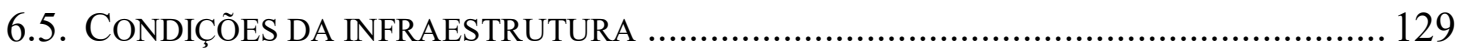

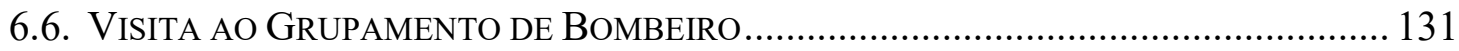

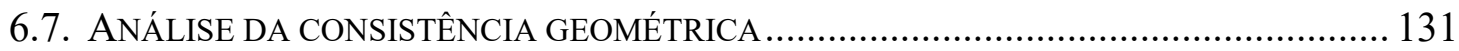

6.7.1. Determinação da Velocidade Operacional Potencial - V ${ }_{85 p} \ldots \ldots \ldots \ldots \ldots \ldots . . . . . . .131$

6.7.2. Determinação da Velocidade Operacional Efetiva $-V_{85 e} \ldots \ldots \ldots \ldots \ldots \ldots . . . . . . . .132$

6.7.3. Critérios de classificação I, II e ICG ................................................. 132

6.8. ANÁLISE DOS BANCOS DE DADOS DE ACIDENTES ................................................. 136

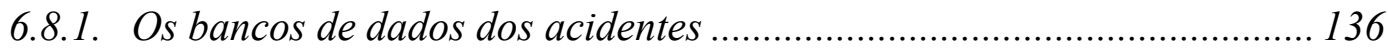

6.8.2. Distribuição das frequências dos acidentes ......................................... 138

6.9. RELAÇÃO DOS ACIDENTES COM AS CARACTERÍSTICAS DA VIA........................... 145

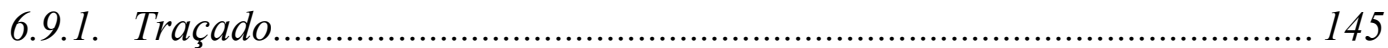

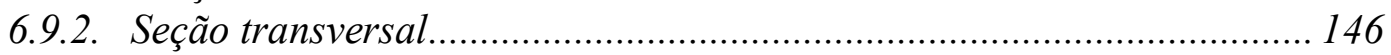

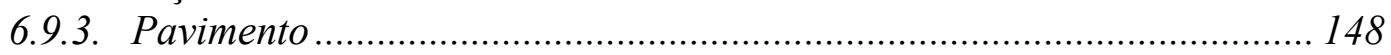

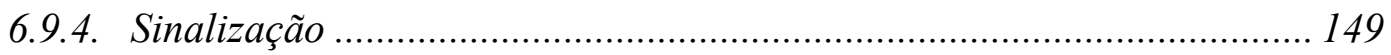

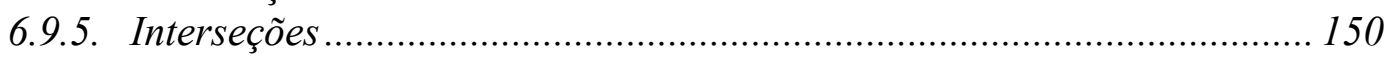

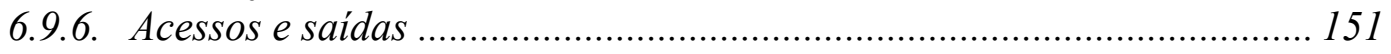

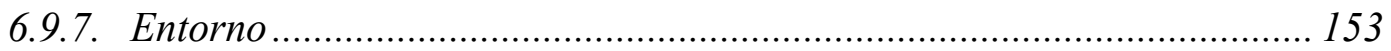

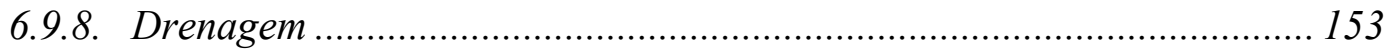

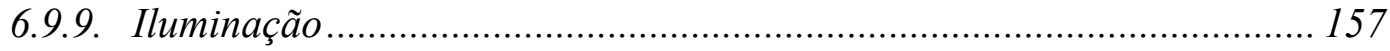

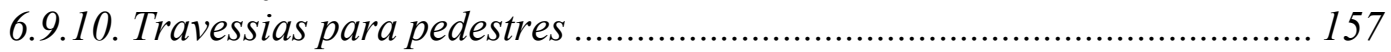

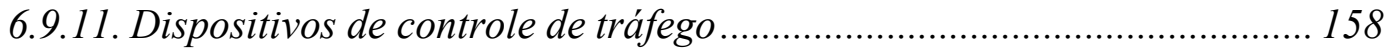

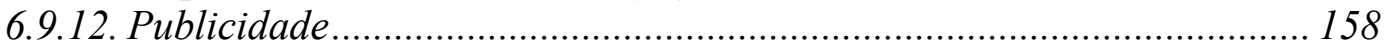

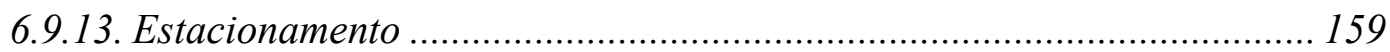




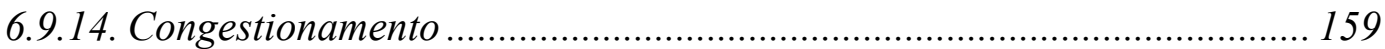

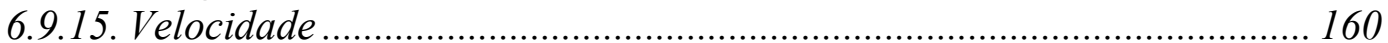

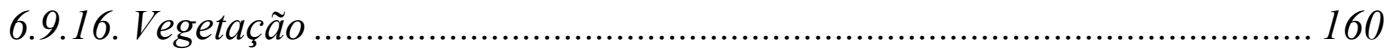

7. CONCLUSÕES E SUGESTÕES PARA TRABALHOS FUTUROS.................. 163

8. REFERÊNCIAS BIBLIOGRÁFICAS ............................................................. 169 


\section{INTRODUÇÃO}

Apesar dos grandes esforços realizados no Brasil e no mundo no que se refere à segurança rodoviária, os acidentes de trânsito ainda se apresentam como um sério problema de saúde pública. Segundo dados da Organização Mundial da Saúde (WHO), divulgados em 2009, referentes ao ano de 2004, o número de mortes em acidentes de trânsito ocupava o nono lugar no ranking de causas de mortes, correspondendo a $2,1 \%$ de todas as mortes, como mostrado na Tabela 1.1. A previsão para 2030 é de que passe a ocupar a quarta colocação, atingindo $3,6 \%$ das mortes no mundo.

Tabela 1.1: Ranking da causa de mortes no mundo

\begin{tabular}{l|ccc}
\hline & Causas das mortes & $\begin{array}{c}\text { \% das mortes } \\
(\mathbf{2 0 0 4 )}\end{array}$ & $\begin{array}{c}\text { \% das mortes } \\
(\mathbf{2 0 3 0 )}\end{array}$ \\
\hline $\mathbf{1}^{\mathbf{0}}$ & Doenças cardíacas & $12,2 \%$ & $14,2 \%$ \\
$\mathbf{2}^{\mathbf{0}}$ & Doenças cerebrovasculares & $9,7 \%$ & $12,1 \%$ \\
$\mathbf{3}^{\mathbf{0}}$ & Doenças respiratórias & $7,0 \%$ & $3,8 \%$ \\
$\mathbf{4}^{\mathbf{0}}$ & Doenças pulmonares crônicas & $5,1 \%$ & $8,6 \%$ \\
$\mathbf{5}^{\mathbf{0}}$ & Diarreia & $3,6 \%$ & - \\
$\mathbf{6}^{\mathbf{0}}$ & HIV/AIDS & $3,5 \%$ & $1,8 \%$ \\
$\mathbf{7}^{\mathbf{0}}$ & Câncer de pulmão, traqueia e brônquios & $2,3 \%$ & $3,4 \%$ \\
$\mathbf{8}^{\mathbf{0}}$ & Tuberculose & $2,5 \%$ & $1,0 \%$ \\
$\mathbf{9}^{\mathbf{0}}$ & Acidentes de trânsito & $\mathbf{2 , 2 \%}$ & $\mathbf{3 , 6 \%}$ \\
$\mathbf{1 0}^{\mathbf{0}}$ & Mortalidade infantil & $2,0 \%$ & - \\
\hline
\end{tabular}

Fonte: Adaptado de Global Status Report on Road Safety, WHO, 2009.

O Brasil se destaca nessas estatísticas, ocupando o quinto lugar com 35.155 óbitos em 2004, atrás da Índia (105.725 óbitos), China (96.611 óbitos), Estados Unidos (42.642 óbitos) e Federação Russa (35.942 óbitos) (WHO: 2009). Ao se atualizar os dados para o ano de 2013, a situação fica ainda mais crítica ao se notar que o Brasil sobe duas posições e passa a ocupar a terceira posição com dados estimados de 36.499 mortos (WHO: 2013). Os dados dos dois relatórios da WHO (World Health Organization) estão apresentados na Tabela 1.2. 
Tabela 1.2: Ranking dos países com maior número de óbitos em 2009 e em 2013

\begin{tabular}{|c|c|c|c|c|c|c|}
\hline \multicolumn{3}{|c|}{2009} & \multicolumn{3}{|c|}{2013} & \multirow[b]{2}{*}{$\begin{array}{c}\text { Variação } \\
\text { no } \\
\text { período }\end{array}$} \\
\hline & Países & $\begin{array}{l}\mathrm{N}^{0} \text { de } \\
\text { mortes }\end{array}$ & & Países & $\begin{array}{l}\mathrm{N}^{0} \text { de } \\
\text { mortes }\end{array}$ & \\
\hline $\mathbf{1}^{\mathbf{o}}$ & Índia & 105.725 & $1^{\mathrm{o}}$ & Índia & 130.037 & $23,00 \%$ \\
\hline $2^{\circ}$ & China & 96.611 & $2^{o}$ & China & 70.134 & $-27,41 \%$ \\
\hline $3^{\mathbf{o}}$ & Estados Unidos & 42.642 & $3^{\mathbf{o}}$ & Brasil & 36.499 & $3,82 \%$ \\
\hline $4^{\circ}$ & Federação Russa & 35.972 & $4^{\mathrm{o}}$ & Estados Unidos & 32.885 & $-22,88 \%$ \\
\hline $5^{\circ}$ & Brasil & 35.155 & $5^{\circ}$ & Indonésia & 31.234 & $88,75 \%$ \\
\hline $6^{\mathbf{0}}$ & Irã & 22.918 & $6^{\mathrm{o}}$ & Federação Russa & 26.567 & $-26,15 \%$ \\
\hline $7^{\circ}$ & México & 22.103 & $7^{\circ}$ & Irã & 23.249 & $1,44 \%$ \\
\hline $8^{\circ}$ & Indonésia & 16.548 & $8^{\circ}$ & México & 17.301 & $-21,73 \%$ \\
\hline $9^{\circ}$ & África do Sul & 16.113 & $9^{\circ}$ & África do Sul & 14.804 & $-8,12 \%$ \\
\hline $10^{\circ}$ & Egito & 15.948 & $10^{\circ}$ & Tailândia & 13.365 & $6,99 \%$ \\
\hline
\end{tabular}

Fonte: adaptado de WHO (2009) e WHO (2013).

No entanto, segundo Waiselfisz (2014), o número de mortes em acidentes ultrapassou os 40 mil óbitos, chegando a 46.051. Dados esses que são preocupantes, uma vez que países desenvolvidos e os emergentes, chamados BRICS, apresentaram tendência de queda dos resultados, excetuando-se a Índia.

Focando-se no Brasil e na distribuição dos acidentes pelos seus estados, vê-se uma concentração na região Sudeste, principalmente nos estados de São Paulo e Minas Gerais (WAISELFISZ: 2014). Os dados apresentados na Tabela 1.3, Figura 1.1 e Figura 1.2 permitem visualizar a situação dos estados e regiões brasileiras com relação à mortalidade no trânsito. As condições das capitais brasileiras, apresentadas na Tabela 1.4, mostram uma grande concentração de óbitos nas cidades do Rio de Janeiro, São Paulo e Fortaleza.

Embora seja notável que um grande número de acidentes tenha a causa classificada como fator humano, ressalta-se que a intervenção viária muitas vezes é utilizada para reduzir sensivelmente o número de acidentes. Com base nisso, Nodari e Lindau (2004) apud Sampedro (2010) afirmam que:

Ambientes viários complexos podem imputar exigências excessivas sobre a habilidade de motoristas médios. Mais simples e menos oneroso que treinar motoristas para níveis de habilidade superiores, seria investir em 
medidas de engenharia para simplificar o ambiente viário de forma a facilitar o ato de dirigir. É importante destacar que as medidas de engenharia são apontadas como capazes de influenciar mudanças mais rápidas no comportamento do motorista do que medidas de educação ou fiscalização. É o caso do fator via, no qual atuações sobre ele para adequar os ambientes rodoviários e aumentar as condições de segurança permitem uma diminuição mais rápida e maior do número e da gravidade dos acidentes de trânsito (NODARI, LINDAU, 2004 apud SAMPEDRO, 2010, p. 2).

Tabela 1.3: Número de óbitos em acidentes no Brasil entre 2002 e 2012

SUL

\begin{tabular}{|c|c|c|c|c|c|c|c|c|c|c|c|c|c|}
\hline \multirow{2}{*}{ UF/REGIÃO } & \multirow{2}{*}{2002} & \multirow{2}{*}{2003} & \multirow{2}{*}{2004} & \multirow{2}{*}{2005} & \multirow{2}{*}{2006} & \multirow{2}{*}{2007} & \multirow{2}{*}{2008} & \multirow{2}{*}{2009} & \multirow{2}{*}{2010} & \multirow{2}{*}{2011} & \multirow{2}{*}{2012} & \multicolumn{2}{|c|}{$\Delta \%$} \\
\hline & & & & & & & & & & & & $02 / 12$ & $11 / 12$ \\
\hline Acre & 134 & 101 & 87 & 99 & 85 & 102 & 119 & 126 & 141 & 168 & 164 & $22,4 \%$ & $-2,4 \%$ \\
\hline Amapá & 127 & 116 & 119 & 110 & 123 & 100 & 95 & 113 & 136 & 155 & 127 & $0,0 \%$ & $-18,1 \%$ \\
\hline Amazonas & 315 & 340 & 404 & 414 & 437 & 382 & 469 & 421 & 502 & 554 & 511 & $62,2 \%$ & $-7,8 \%$ \\
\hline Pará & 909 & 918 & 911 & 1011 & 1054 & 1112 & 1174 & 1065 & 1449 & 1458 & 1685 & $85,4 \%$ & $15,6 \%$ \\
\hline Rondônia & 367 & 399 & 386 & 427 & 456 & 381 & 487 & 513 & 613 & 603 & 674 & $83,7 \%$ & $11,8 \%$ \\
\hline Roraima & 141 & 84 & 85 & 105 & 111 & 145 & 122 & 129 & 147 & 137 & 151 & $7,1 \%$ & $10,2 \%$ \\
\hline Tocantins & 368 & 370 & 471 & 400 & 364 & 453 & 482 & 468 & 541 & 556 & 580 & $57,6 \%$ & $4,3 \%$ \\
\hline NORTE & 2361 & 2328 & 2463 & 2566 & 2630 & 2675 & 2948 & 2835 & 3529 & 3631 & 3892 & $64,8 \%$ & $7,2 \%$ \\
\hline Alagoas & 590 & 525 & 571 & 595 & 579 & 669 & 602 & 673 & 798 & 860 & 846 & $43,4 \%$ & $-1,6 \%$ \\
\hline Bahia & 1344 & 1310 & 1326 & 1790 & 1753 & 1968 & 1785 & 1889 & 2662 & 2745 & 2991 & $122,5 \%$ & $9,0 \%$ \\
\hline Ceará & 1525 & 1586 & 1686 & 1766 & 1704 & 1736 & 1756 & 1599 & 2210 & 2247 & 2492 & $63,4 \%$ & $10,9 \%$ \\
\hline Maranhão & 682 & 682 & 766 & 909 & 850 & 1041 & 1164 & 1154 & 1337 & 1517 & 1705 & $150,0 \%$ & $12,4 \%$ \\
\hline Paraíba & & 541 & 656 & 665 & 713 & 722 & 818 & 8 & 838 & 811 & 996 & $47,6 \%$ & $22,8 \%$ \\
\hline Pernambuco & 1503 & 1405 & 1423 & 1427 & 1453 & 1450 & 1561 & 1800 & 1990 & 2011 & 2077 & $38,2 \%$ & $3,3 \%$ \\
\hline Piauí & 536 & 541 & 585 & 643 & 781 & 785 & 839 & 915 & 1056 & 1092 & 1215 & $126,7 \%$ & $11,3 \%$ \\
\hline Rio Grande do Norte & 429 & 399 & 437 & 461 & 487 & 479 & 471 & 507 & 658 & 607 & 613 & $42,9 \%$ & $1,0 \%$ \\
\hline Sergipe & 434 & 404 & 454 & 393 & 376 & 445 & 476 & 537 & 631 & 590 & 652 & $50,2 \%$ & $10,5 \%$ \\
\hline NORDESTE & 7718 & 7393 & 7904 & 8649 & 8696 & 9295 & 9472 & 9878 & 12180 & 12480 & 13587 & $76,0 \%$ & $8,9 \%$ \\
\hline Espírito & 954 & 859 & 874 & 878 & 949 & 1054 & 1071 & 964 & 1151 & 1159 & 1187 & $24,4 \%$ & $2,4 \%$ \\
\hline Minas Gerais & 2947 & 3129 & 3518 & 3615 & 3862 & 4007 & 4121 & 4087 & 4578 & 4830 & 4692 & $59,2 \%$ & $-2,9 \%$ \\
\hline Rio de Janeiro & 2832 & 2856 & 2921 & 2936 & 3137 & 2726 & 2639 & 2373 & 2918 & 2796 & 3068 & $8,3 \%$ & $9,7 \%$ \\
\hline São Paulo & 6404 & 7025 & 7045 & 7184 & 7305 & 7802 & 7748 & 7164 & 7460 & 7681 & 7306 & $14,1 \%$ & $-4,9 \%$ \\
\hline SUDESTE & 13137 & 13869 & 14358 & 14613 & 15253 & 15589 & 15579 & 14588 & 16107 & 16466 & 16253 & $23,7 \%$ & $-1,3 \%$ \\
\hline Paraná & 2647 & 2809 & 3136 & 3028 & 2978 & 3211 & 3233 & 3144 & 3460 & 3387 & 3646 & $37,7 \%$ & $7,6 \%$ \\
\hline Rio Grande do Sul & 2094 & 2029 & 2113 & 2045 & 1985 & 1954 & 2061 & 2029 & 2249 & 2086 & 2115 & $1,0 \%$ & $1,4 \%$ \\
\hline Santa Catarina & 1670 & 1683 & 1836 & 1899 & 1962 & 1934 & 1857 & 1844 & 1865 & 2029 & 1927 & $15,4 \%$ & $-5,0 \%$ \\
\hline SUL & 6411 & 6521 & 7085 & 6972 & 6925 & 7099 & 7151 & 7017 & 7574 & 7502 & 7688 & $19,9 \%$ & $2,5 \%$ \\
\hline Distrito Federal & 604 & 684 & 585 & 610 & 581 & 630 & 616 & 582 & 640 & 644 & 555 & $-8,1 \%$ & $-13,8 \%$ \\
\hline Goiás & 1540 & 1454 & 1629 & 1563 & 1437 & 1505 & 1656 & 1726 & 1949 & 1865 & 2062 & $33,9 \%$ & $10,6 \%$ \\
\hline Mato Grosso & 889 & 769 & 943 & 888 & 1038 & 928 & 1071 & 1129 & 1133 & 1102 & 1184 & $33,2 \%$ & $7,4 \%$ \\
\hline Mato Grosso do Sul & 628 & 601 & 707 & 749 & 689 & 698 & 718 & 714 & 796 & 863 & 830 & $32,2 \%$ & $-3,8 \%$ \\
\hline CENTRO-OESTE & 3661 & 3508 & 3864 & 3810 & 3745 & 3761 & 4061 & 4151 & 4518 & 4474 & 4631 & $26,5 \%$ & $3,5 \%$ \\
\hline BRASIL & 33288 & 33619 & 35674 & 36610 & 37249 & 38419 & 39211 & 38469 & 43908 & 44553 & 46051 & $38,3 \%$ & $3,4 \%$ \\
\hline
\end{tabular}

Fonte: Waiselfisz (2014). 


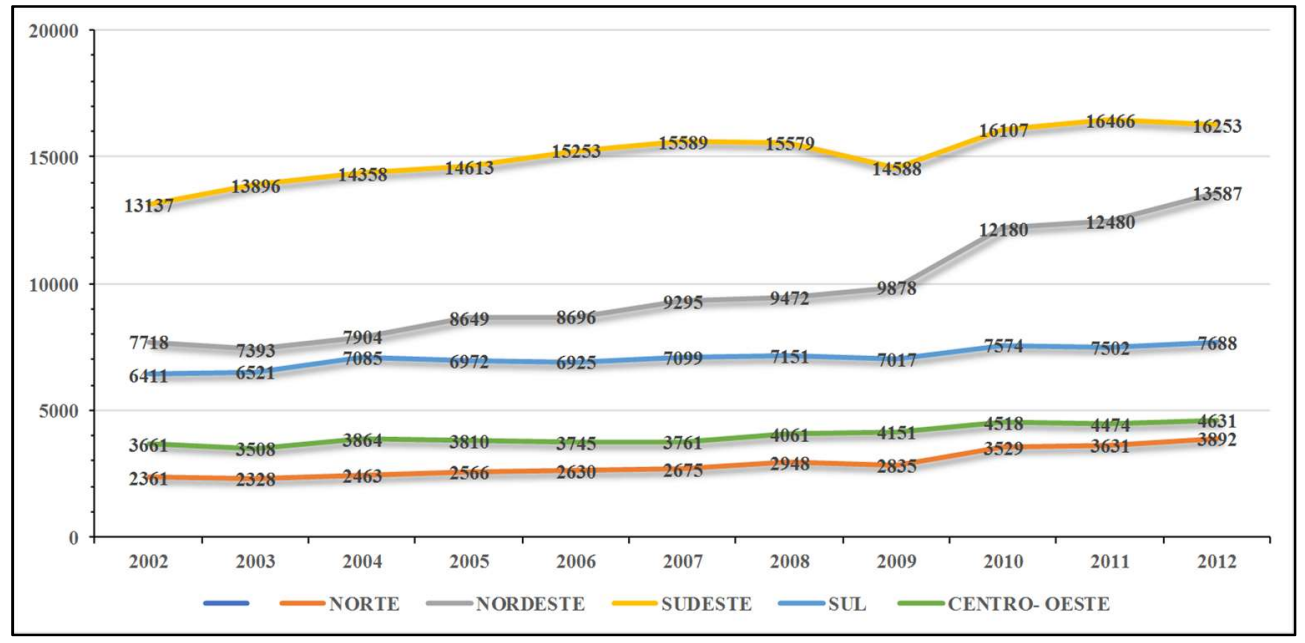

Figura 1.1: Evolução do Número de óbitos em acidentes por região do Brasil entre 2002 e 2012 Fonte: Adaptado de Waiselfisz (2014).

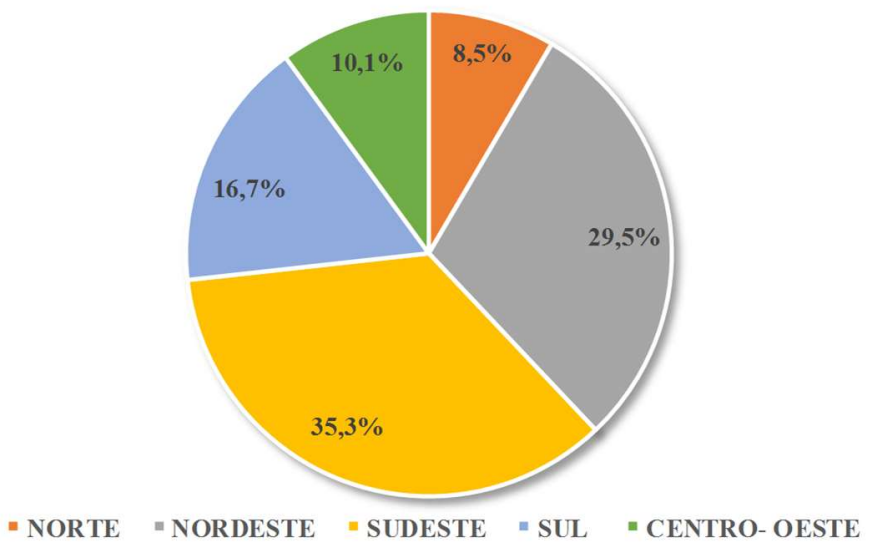

Figura 1.2: Participação das regiões no número de óbitos em acidentes em 2012 Fonte: Adaptado de Waiselfisz (2014).

O governo brasileiro, no intuito de reduzir o número e as consequências dos acidentes, elaborou diversas ações e estratégias. Com a criação do Programa de Redução dos Acidentes de Trânsito (Pare), em 1993, priorizou o desenvolvimento de estudos buscando a melhoria do ambiente viário, principalmente no que tange às condições das vias, à sinalização, à operação e ao desenvolvimento de métodos para identificar, com maior precisão, os fatores contribuintes dos acidentes e planejar ações corretivas (MT: 2013). Também, com a participação do Departamento Nacional de Trânsito (Denatran), têm sido fomentados projetos e campanhas educativas destinadas à diminuição dos acidentes de trânsito (Denatran: 2013). 
Tabela 1.4: Número de óbitos em acidentes de trânsito nas capitais brasileiras entre 2002 e 2012

\begin{tabular}{|c|c|c|c|c|c|c|c|c|c|c|c|c|c|}
\hline \multirow{2}{*}{ UF/REGIÃO } & \multirow{2}{*}{2002} & \multirow{2}{*}{2003} & \multirow{2}{*}{2004} & \multirow{2}{*}{2005} & \multirow{2}{*}{2006} & \multirow{2}{*}{2007} & \multirow{2}{*}{2008} & \multirow{2}{*}{2009} & \multirow{2}{*}{2010} & \multirow{2}{*}{2011} & \multirow{2}{*}{2012} & \multicolumn{2}{|c|}{$\Delta \%$} \\
\hline & & & & & & & & & & & & $02 / 12$ & $11 / 12$ \\
\hline Belém & 287 & 305 & 251 & 326 & 183 & 143 & 140 & 128 & 151 & 153 & 134 & $-53,3 \%$ & $-12,4 \%$ \\
\hline Boa Vista & 104 & 52 & 49 & 73 & 78 & 104 & 85 & 89 & 96 & 97 & 94 & $-9,6 \%$ & $-3,1 \%$ \\
\hline Macapá & 111 & 97 & 100 & 90 & 104 & 83 & 76 & 91 & 110 & 117 & 104 & $-6,3 \%$ & $-11,1 \%$ \\
\hline Manaus & 231 & 262 & 309 & 297 & 349 & 282 & 276 & 245 & 351 & 373 & 323 & $39,8 \%$ & $-13,4 \%$ \\
\hline Palmas & 70 & 79 & 70 & 82 & 77 & 112 & 92 & 99 & 103 & 114 & 108 & $54,3 \%$ & $-5,3 \%$ \\
\hline Porto Velho & 131 & 125 & 124 & 161 & 226 & 181 & 185 & 199 & 260 & 245 & 269 & $105,3 \%$ & $9,8 \%$ \\
\hline Rio Branco & 97 & 67 & 59 & 71 & 52 & 81 & 82 & 99 & 99 & 103 & 93 & $-4,1 \%$ & $-9,7 \%$ \\
\hline NORTE & $1031^{\prime}$ & $987^{\prime}$ & 962 & 1100 & $1069^{\prime}$ & 986 & 936 & $950^{\prime}$ & 1170 & 1202 & 1125 & $9,1 \%$ & $-6,4 \%$ \\
\hline Aracaju & 181 & 189 & 204 & 177 & 200 & 189 & 227 & 278 & 279 & 290 & 251 & $38,7 \%$ & $-13,4 \%$ \\
\hline Fortaleza & 635 & 567 & 613 & 632 & 612 & 627 & 438 & 368 & 610 & 648 & 679 & $6,9 \%$ & $4,8 \%$ \\
\hline João Pessoa & 202 & 178 & 178 & 199 & 174 & 181 & 200 & 205 & 226 & 193 & 213 & $5,4 \%$ & $10,4 \%$ \\
\hline Maceió & 280 & 225 & 227 & 240 & 225 & 203 & 214 & 202 & 244 & 266 & 247 & $-11,8 \%$ & $-7,1 \%$ \\
\hline Natal & 111 & 107 & 99 & 113 & 81 & 86 & 111 & 103 & 163 & 126 & 120 & $8,1 \%$ & $-4,8 \%$ \\
\hline Recife & 522 & 506 & 543 & 520 & 494 & 524 & 540 & 604 & 680 & 607 & 538 & $3,1 \%$ & $-11,4 \%$ \\
\hline Salvador & & & 145 & & & & & 167 & & & 455 & $155,6 \%$ & \\
\hline São Luís & 190 & 185 & 191 & 221 & 210 & 243 & 295 & 281 & 297 & 303 & 336 & $76,8 \%$ & $10,9 \%$ \\
\hline Teresina & 277 & 289 & 284 & 276 & 354 & 384 & 370 & 375 & 471 & 438 & 476 & $71,8 \%$ & $8,7 \%$ \\
\hline NORDESTE & 2576 & 2423 & 2484 & 2874 & 2837 & 2834 & 2562 & 2583 & 3440 & 3278 & 3315 & $28,7 \%$ & $1,1 \%$ \\
\hline Belo Horizonte & 581 & 576 & 608 & 596 & 708 & 670 & 652 & 596 & 625 & 609 & 542 & $-6,7 \%$ & $-11,0 \%$ \\
\hline Rio de Janeiro & 1147 & 1025 & 1107 & 978 & 1083 & 726 & 903 & 865 & 1002 & 832 & 1072 & $-6,5 \%$ & $28,8 \%$ \\
\hline São Paulo & 827 & 1528 & 1445 & 1579 & 1593 & 1844 & 1558 & 1483 & 1461 & 1472 & 1350 & $63,2 \%$ & $-8,3 \%$ \\
\hline Vitória & 162 & 160 & 160 & 174 & 153 & 161 & 171 & 146 & 159 & 121 & 118 & $-27,2 \%$ & $-2,5 \%$ \\
\hline SUDESTE & 2717 & 3289 & 3320 & 3327 & 3537 & 3401 & 3284 & 3090 & 3247 & 3034 & 3082 & $13,4 \%$ & $1,6 \%$ \\
\hline Curitiba & 464 & 487 & 537 & 530 & 483 & 514 & 500 & 448 & 401 & 416 & 356 & $-23,3 \%$ & $-14,4 \%$ \\
\hline Florianópolis & 99 & 93 & 102 & 120 & 147 & 115 & 129 & 91 & 96 & 84 & 98 & $-1,0 \%$ & $16,7 \%$ \\
\hline Porto Alegre & 379 & 346 & 329 & 312 & 265 & 259 & 274 & 271 & 248 & 213 & 168 & $-55,7 \%$ & $-21,1 \%$ \\
\hline SUL & 942 & 926 & 968 & 962 & 895 & 888 & 903 & 810 & 745 & 713 & 622 & $-34,0 \%$ & $-12,8 \%$ \\
\hline Brasília & 604 & 684 & 585 & 610 & 581 & 630 & 616 & 582 & 640 & 644 & 555 & $-8,1 \%$ & $-13,8 \%$ \\
\hline Campo Grande & 201 & 203 & 220 & 243 & 209 & 198 & 227 & 193 & 227 & 224 & 205 & $2,0 \%$ & $-8,5 \%$ \\
\hline Cuiabá & 226 & 160 & 156 & 154 & 158 & 166 & 192 & 195 & 209 & 223 & 198 & $-12,4 \%$ & $-11,2 \%$ \\
\hline Goiânia & 536 & 564 & 568 & 581 & 524 & 586 & 598 & 606 & 677 & 559 & 598 & $11,6 \%$ & $7,0 \%$ \\
\hline CENTRO-OESTE & 1567 & 1611 & 1529 & 1588 & 1472 & 1580 & 1633 & 1576 & 1753 & 1650 & 1556 & $-0,7 \%$ & $-5,7 \%$ \\
\hline BRASIL & 8833 & 9236 & 9263 & 9851 & 9810 & 9689 & 9318 & 9009 & 10355 & 9877 & 9700 & $9,8 \%$ & $-1,8 \%$ \\
\hline
\end{tabular}

Fonte: Waiselfisz (2014).

Apesar da tendência em subestimar os efeitos das características e das condições da via sobre a ocorrência de acidentes de trânsito, o sistema viário, no seu conjunto, cria situações que podem induzir os motoristas a cometer erros de percepção ou de reação e, consequentemente, propícias para a ocorrência de acidentes (MAIA: 1995; SAMPEDRO: 2006). Ambientes viários complexos podem afetar, principalmente, motoristas e pedestres pouco experientes, mas em determinadas ocasiões também levam condutores habilidosos a enfrentar exigências e riscos inesperados (NODARI: 2003). 
Por outro lado, Picado (2005) reconhece que os estudos sobre o efeito das características da via sobre a segurança do tráfego são recentes e limitados. As limitações desse conhecimento estão relacionadas, especialmente, aonde as características da via influenciam a segurança de tráfego, à magnitude da influência, à ausência de qualquer entendimento sobre o efeito de algumas características sobre a segurança e à precariedade da disponibilidade de dados de acidentes no âmbito brasileiro.

Diante do que foi exposto, há necessidade de aprofundamento dos estudos de segurança no tráfego em rodovias e vias urbanas, com uma análise que relacione as características físicas e operacionais à segurança das vias. Desse modo, esse trabalho irá apresentar um estudo de caso com o intuito de exemplificar que essas vinculações se fazem presentes.

Algumas questões são importantes para avançar no entendimento do efeito das características das rodovias e vias urbanas sobre a segurança do tráfego. Esta pesquisa pretende dar resposta às seguintes questões:

1. Como as características físicas e operacionais das rodovias e vias urbanas se relacionam com a segurança de tráfego?

2. Quais são as características físicas e operacionais ideais das rodovias e vias urbanas brasileiras?

\subsection{OBJETIVOS}

\subsubsection{Objetivo principal}

Este trabalho tem como objetivo principal analisar a influência das características da via sobre a ocorrência de acidentes, empregando um software para auxiliar na avaliação da consistência geométrica e na identificação de pontos críticos (locais de acidentes). Para tal, foi realizado um estudo de caso na Autoestrada Grajaú-Jacarepaguá e a análise foi feita utilizando os dados de acidentes registrados entre os anos de 2011 e 2015. 


\subsubsection{Objetivos específicos}

a. Estabelecer as características geométricas atuais da Autoestrada Grajaú-Jacarepaguá, principalmente alinhamento horizontal e alinhamento vertical, para futuro estudo da consistência do projeto geométrico.

b. Analisar a consistência do projeto geométrico por meio do software Saepro a fim de identificar locais onde poderiam ser caracterizados como pontos críticos.

c. Coletar e tratar os dados de acidentes de trânsito registrados na Autoestrada GrajaúJacarepaguá, entre os anos de 2011 e 2015, obtidos junto a órgão competente, de modo a compor um banco de dados.

d. A partir do banco de dados, elaborar estatísticas dos acidentes de trânsito em forma de tabelas e gráficos.

e. Relacionar os acidentes na Autoestrada Grajaú-Jacarepaguá com as características da Autoestrada.

\subsection{ESTRUTURA DO TRABALHO}

No capítulo 2 são apresentados, com base na revisão bibliográfica, os fatores contribuintes e sua influência na ocorrência de acidentes de trânsito. Abordam-se as principais questões relacionadas com os riscos no tráfego, assim como os processos de avaliação e percepção de riscos como ferramentas importantes para reduzir os impactos dos acidentes de trânsito. Com isso, pretende-se entender os aspectos e as complexidades próprias desses processos.

No capítulo 3 será abordado o estudo do conjunto viário e a sua influência na segurança dos

pedestres e motoristas. É apresentado um resumo dos principais componentes físicos e operacionais da infraestrutura da via sobre a segurança. São relacionados os efeitos das principais características observadas nas maiorias das vias, como, por exemplo, o projeto geométrico e seus elementos, os dispositivos de sinalização, os aspectos relacionados à seção transversal, a qualidade do pavimento utilizado, como são realizadas as interseções, e os dispositivos de controle. Na parte final é enfatizado o estudo das rodovias e vias urbanas, em especial ao estudo de caso posteriormente enunciado, tratando os seus aspectos operacionais, e gerenciais.

O capítulo 4 aborda a consistência geométrica, mostrando os principais modelos de previsão operacionais desenvolvidos ao longo do tempo, uma proposta de classificação através do 
índice de consistência geométrica (ICG) e as principais ferramentas utilizadas para a análise do projeto geométrico.

No capítulo 5 é detalhado o método utilizado neste trabalho, enumerando-se a série de atividades realizadas.

No capítulo 6 apresenta-se um estudo de caso para exemplificar os aspectos analisados, considerando-se os dados de acidentes e relacionando-se às prováveis causas com as características da via e de seu entorno.

O capítulo 7 traz as considerações finais do estudo, assim como as principais conclusões e sugestões para trabalhos futuros. 


\section{SEGURANÇA VIÁRIA E ACIDENTES DE TRÂNSITO}

Não se pode restringir a análise dos problemas de segurança viária apenas à simples consideração da soma total e da severidade dos acidentes de trânsito acontecidos em determinada via ou região (TRB: 2004). Geralmente é a abrangência de um conjunto de condições e fatores interligados na segurança viária que propiciam a circulação e interação dos diferentes elementos do sistema de tráfego na rede viária sob níveis aceitáveis de risco e de forma suficientemente segura.

Para abordar os problemas de segurança viária é importante conhecer os diferentes fatores que contribuem para a ocorrência dos acidentes de trânsito e os riscos associados a estes. É necessário aprofundar o entendimento da natureza e dos tipos de riscos presentes no tráfego, da maneira como os usuários do trânsito percebem e reagem diante das diferentes situações e quais são os mecanismos existentes para a avaliação e o gerenciamento dos elementos de risco.

\subsection{FATORES CONTRIBUINTES NOS ACIDENTES DE TRÂNSITO}

Quando se fala na questão de segurança de tráfego, Gold (1998) propõe isolar, primeiramente, os principais elementos constituintes do sistema de trânsito, como os veículos, as pessoas, o ambiente institucional, o meio ambiente e as vias.

Todos esses elementos interagem a partir da entrada do homem em cada um desses componentes, como mostrado na Figura 2.1. O homem pode desempenhar vários papéis: pedestre, motorista, ciclista, motociclista, e, até mesmo, agente de trânsito. Como motorista, suas ações serão respostas aos estímulos fornecidos pelo meio ambiente, cenários da circulação (GOLD: 1998).

\section{a) Fatores veiculares}

São os fatores relacionados diretamente ao automóvel, desde o projeto de segurança e fabricação, até as questões de manutenção e conservação do veículo. Um acidente em que o fator veicular é a maior causa, a análise deverá ser feita em cima dos mecanismos de controle e direção do veículo. Falha do sistema de freios, má conservação dos pneus, problemas com a suspensão e o não acionamento dos airbags são exemplos das causas veiculares nos acidentes. 


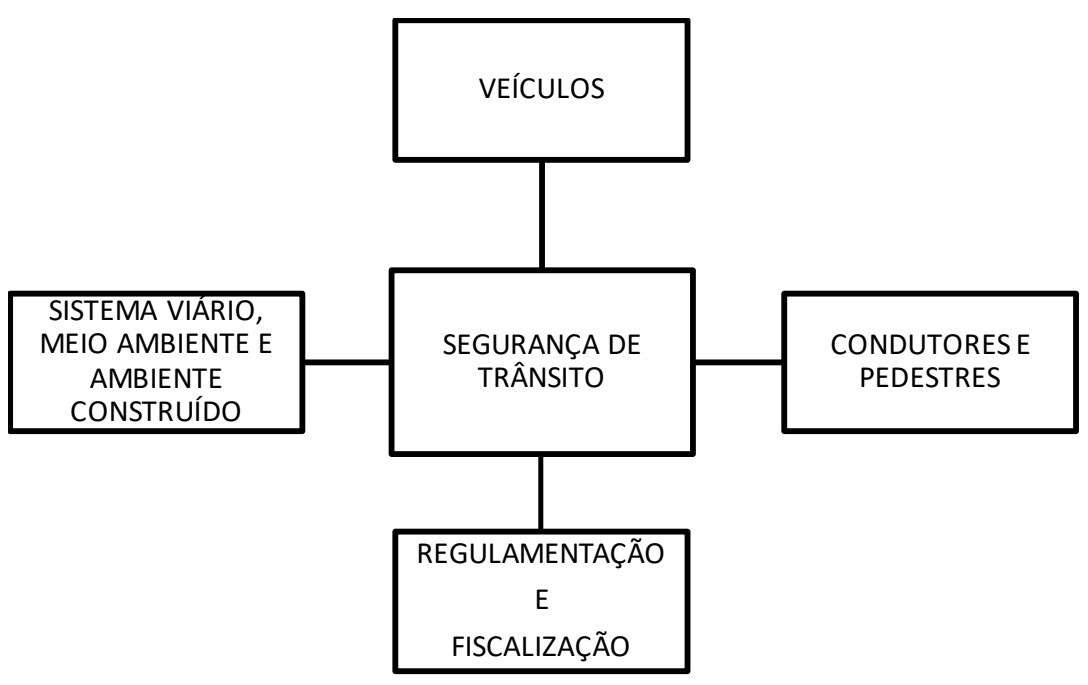

Figura 2.1: Fatores que afetam a segurança de trânsito.

Fonte: Gold (1998).

b) Fator humano

O fator humano refere-se a inúmeras atribuições que afetam o comportamento humano no que consiste o ambiente de tráfego, indo desde aspectos mais amplos, como a condição social, sexo, idade, físico e psicológico, até aspectos mais singulares como inexperiência no trânsito, personalidade ou deficiências. Pode-se classificá-lo em três áreas distintas: comportamental, cognitiva e fisiológica.

\section{b.1) Aspectos comportamentais}

Resumem-se às características psicológicas do homem, seja em qual papel desempenha no trânsito. A exemplo disso pode-se assumir tais aspectos como a personalidade do motorista no trânsito, a educação da sociedade ao entorno das vias, a prudência dos ciclistas, as noções de responsabilidades dos pedestres etc.

\section{b.2) Aspectos cognitivos}

Relacionam-se às características de aprendizado ou inexperiência do homem. A exemplo disso têm-se as questões do poder de julgamento do agente de trânsito, o grau e tempo de instrução do motorista e o grau de conhecimento das regras de trânsito na sociedade em geral. 


\section{b.3) Aspectos fisiológicos}

Concerne ao grau de alteração das funções corporais do homem. Esse é o aspecto, provavelmente, que mais aparece nos boletins de ocorrência policiais. A exemplo disso têmse questões de embriaguez, estresse, sonolência, efeito de medicamentos, cansaço e deficiências físico-motoras.

\section{c) Fator institucional}

Dificilmente é relacionado nas análises de acidentes de pontos críticos, porém é um fator de destaque. Nesse fator estão incluídas, principalmente, a regulamentação e a fiscalização. Pode-se citar como exemplos a inadequação do treinamento dos condutores brasileiros, as lacunas de informação, que ainda seguindo as diretrizes do Código de Trânsito Brasileiro podem estar deixando a desejar, e as questões de falta de fiscalização ou presença policial nos lugares e a impunidade das situações pós-acidentes. Vale lembrar que a falta ou escassez do fator institucional não retira os deveres e direitos dos usuários.

\section{d) Fator ambiental}

Os fatores ambientais são pouco mencionados, mas também são fatores contribuintes dos acidentes. Os fenômenos da natureza que podem ser atribuídos como principais elementos são: chuva e neve, que reduzem a aderência entre o veículo e a pista, ventos, dependendo de sua intensidade, neblina e o período de transição entre dia e noite, uma vez que o condutor do automóvel fica suscetível à redução da luminosidade e visibilidade.

\section{e) Fator viário}

O ambiente viário, se mal projetado, pode criar situações propícias a acidentes. Ao se discutir sobre o ambiente viário, discutem-se todos os elementos que compõem o fator viário: projeto geométrico, sinalização, condições da pavimentação, funcionalidade dos dispositivos de drenagem e as características urbanas da via.

Vale lembrar que um acidente não possui apenas um fator para a sua ocorrência, mas todos os fatores interagem e estão relacionados, e são ocasionadores de acidentes. Para Sampedro (2010), é notável a tendência de se considerar os aspectos ligados apenas ao fator humano como responsáveis pela ocorrência de acidentes de trânsito, sem levar em conta os elementos relacionados à via e ao veículo e seu poder de potencializar as falhas humanas. 


\subsection{O RISCO NO TRÂNSITO}

A palavra risco comumente é utilizada para denotar situações muito perigosas. No entanto, ao se discutir risco, prende-se a situações em que o usuário se sinta vulnerável, seja à possibilidade de prejuízo ou de algum dano. Perigo e risco são palavras que são distinguíveis, uma vez que a primeira se associa à toda situação com probabilidade de causar algum acidente, e a segunda define-se como a probabilidade de ocorrência de determinada situação potencialmente perigosa. Em outras palavras, o perigo é a fonte geradora do risco e o risco é resultante da exposição ao perigo.

Pode-se associar o risco no trânsito a quatro elementos principais, que são influenciados pelos fatores anteriormente descritos:

a) Exposição ao risco (fatores econômicos e demográficos, uso e ocupação do solo, planejamento e organização do trânsito);

b) Probabilidade do acidente (velocidade inadequada, uso de álcool e drogas, desenho e traçado da via, condições de manutenção da via e do veículo);

c) Severidade do acidente (não utilização dos elementos de segurança passiva dos veículos, velocidade, obstáculos laterais, coeficiente de atrito-pneu inexistente);

d) Consequências do acidente (tempo de reação das autoridades, presença de fogo ou substancias tóxicas, falhas na atenção médica).

\subsubsection{Avaliação do risco}

Avaliação de risco pode ser definida pelo processo no qual os componentes associados a determinado risco são determinados (RENN: 1998). Pode ser quantitativa, semiquantitativa ou qualitativa, dependendo de aspectos como a natureza do perigo, a utilização da avaliação, os recursos e as informações disponíveis. Parkin e Balbus (2000) relatam a complexidade do processo, que pode envolver questões e matérias variadas, solicitando diferentes níveis de detalhamento técnico.

O objetivo da avaliação de risco é estimar a probabilidade e a severidade de um determinado evento acontecer. Pode ser usada para obter informações que subsidiem a tomada de decisão nos processos de gerenciamento dos riscos ou de regulação e regulamentação da segurança (COWELL et al.: 2002). 
Envolvem-se, geralmente, quatro fases nas avaliações de risco: identificação do risco, estimativa do risco, análise do risco e gerenciamento do risco. Em cada uma dessas fases é necessário levar em conta questões como a probabilidade da ocorrência e a severidade dos eventos, as circunstancias que influenciam determinados acontecimentos e as dificuldades para solucionar ou diminuir as consequências dos problemas encontrados. A Figura 2.2 representa o processo comum de avaliação do risco.

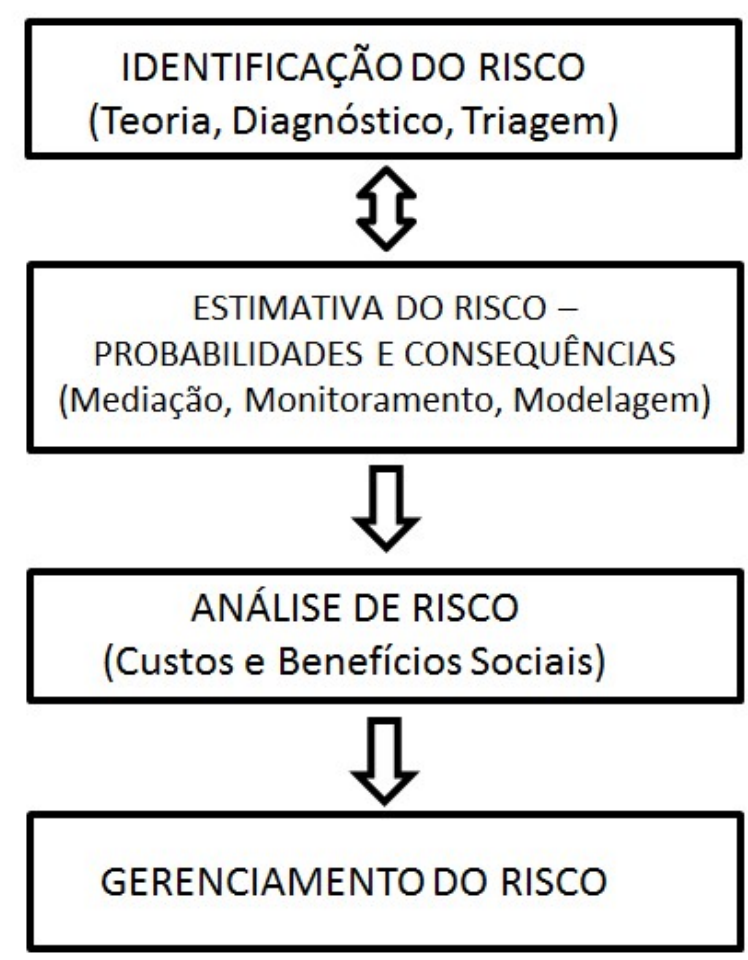

Figura 2.2: Processo de avaliação do risco. Fonte: adaptado de Sampedro (2010).

Como fase de identificação do risco pode-se entender um processo de dedução no qual se procuram ameaças, combinações de situações e os danos potenciais para um objeto de interesse (ALE: 2002). No ambiente viário, podem ser utilizadas diferentes técnicas para a identificação desses perigos potenciais, entre as quais: análise de estatísticas de acidentes, análise de falhas e efeitos, estudo de pontos críticos, estudos do tipo antes e depois, técnicas de conflitos de tráfego e auditorias de segurança viária (DIÓGENES: 2008).

A fase de estimativa dos riscos está bem relacionada com os fatores identificados na etapa anterior. Nesta etapa, os cenários da análise são estabelecidos e as maneiras de se quantificar as consequências potenciais e as probabilidades de ocorrência do evento são avaliadas (ALE: 2002). Os fatores humanos devem ser considerados especialmente, já que influenciam em cada cenário, inclusive na qualificação dos avaliadores. 
$\mathrm{Na}$ terceira fase, as informações obtidas nas etapas anteriores são combinadas com as probabilidades do entorno para completar a descrição do risco. Em geral, são feitas análises quantitativas que dão resultados menos ambíguos e são mais consistentes e controláveis. Apesar de que é possível chegar a resultados concretos a partir da comparação dos valores obtidos, é comum que a redução do nível de risco deva ser decidida com base em uma avaliação de benefício-custo.

A última etapa aparece com o principal objetivo de selecionar e implementar as medidas para diminuir e gerenciar os riscos. Deve-se considerar aspectos sociais, ambientais, operacionais e econômicos para as escolhas das medidas, que devem ser avaliadas e implantadas com base em análises econômicas e técnicas (ALE: 2002). Incluem-se, nessa etapa, medidas de:

- Prevenção de acidentes (redução da probabilidade);

- Resgate (redução de danos pessoais);

- Mitigação das consequências dos acidentes (redução de danos pessoais e materiais).

\subsubsection{Exposição ao risco}

Ao analisar os problemas de segurança é conveniente relacionar a ocorrência de acidentes de trânsito com a movimentação dos indivíduos no sistema de tráfego, procurando parâmetros que expressem ou mensurem quanto os motoristas, pedestres e passageiros se expõem ao risco ao circular pelas vias. O conceito de exposição ao risco sugere uma ideia clara: a frequência esperada de acidentes aumenta na medida em que aumenta o número de viagens, tanto no nível individual quanto social (SAMPEDRO: 2010).

Define-se exposição ao risco como a frequência de eventos no trânsito que criam riscos de acidentes (BRAGA et al.: 2005). Leva-se em conta a interação das demandas do sistema de tráfego e o desempenho dos motoristas, pois permite tanto a diferenciação da experiência ao volante entre condutores que apresentam semelhanças, quanto à quilometragem dirigida durante um período de tempo, mas que estiveram submetidos a situações de tráfego diferentes (complexidade, presença de conflitos etc.). 
Frequentemente, a exposição ao risco é expressa em termos da quilometragem trafegada ou em função do tempo trafegado (CHU: 2004). Apesar disso, pode ser utilizada uma variedade grande de medidas de exposição, dependendo dos elementos que estejam sendo pesquisados (RODRIGUE et al.: 2006). Contudo, a literatura não é conclusiva quanto ao melhor indicador para descrever a exposição ao tráfego. Na Tabela 2.1 são apresentados exemplos de medidas de exposição.

Tabela 2.1: Medidas de exposição ao risco no trânsito

\begin{tabular}{|c|c|}
\hline \multicolumn{2}{|r|}{ Exposição ao risco } \\
\hline Dimensão & Medida \\
\hline \multirow[t]{2}{*}{ Espaço } & Veículos x km dirigidos \\
\hline & Passageiros x km \\
\hline \multirow[t]{3}{*}{ Tempo } & Veículos $\mathrm{x}$ horas dirigidas \\
\hline & Passageiros x horas \\
\hline & Volume médio diário de tráfego \\
\hline \multirow[t]{5}{*}{ População } & Número de motoristas habilitados \\
\hline & Número de veículos registrados \\
\hline & Número de viagens realizadas \\
\hline & Número de passageiros \\
\hline & População \\
\hline
\end{tabular}

Fonte: Adaptado de Rodrigue et al. (2006).

No âmbito brasileiro, Braga et al. (2005) propõem, num estudo da exposição ao tráfego na cidade do Rio de Janeiro, a variável KPH (quilômetros percorridos habilitados), bem como a variável APK (acidentes por quilômetro), como indicadores da exposição ao tráfego e do risco de envolvimento em acidentes de trânsito, respectivamente.

\subsubsection{Percepção do risco}

Há o consenso de que para entender o julgamento e a resposta dos indivíduos ao risco é preciso estudar e compreender o contexto onde eles estão inseridos. Assim, a percepção do risco envolve crenças pessoais, atitudes, julgamentos e sentimentos, bem como valores sociais, culturais e disposições adotadas pelas pessoas diante dos perigos e suas consequências (SAMPEDRO: 2010).

Muitas pessoas tendem a acreditar que correm menos riscos diante de determinados perigos do que a média da população devido às informações que dispõem ou ao processo de raciocínio individual, fatores que as levam a subestimar a magnitude do perigo. A maneira 
com que o risco é percebido pode ser influenciada pelas seguintes condições (CEPIS, 2006 apud SAMPEDRO, 2010):

- Temor: quanto maior o temor às consequências do perigo, maiores serão os cuidados tomados para prevenir os riscos;

- Controle: quando as pessoas sentem que têm algum controle sobre o processo que leva ao risco, a sensação do risco é menor;

- Natureza da origem: os riscos de origem natural são menos percebidos pelos indivíduos que os riscos originados por uma fonte artificial;

- Escolha: o risco tomado por escolha pessoal será menos percebido que outro imposto por outra pessoa;

- Idade: os riscos enfrentados por crianças aparentam ser mais sérios que quando encarados por indivíduos adultos;

- Novos riscos: riscos associados a novas doenças, situações ou tecnologias tendem a ser levados mais em conta do que aqueles causados por situações já experimentadas;

- Conhecimento: quanto maior ciência se tem de um risco, melhor será percebido e será tomado maior cuidado diante dele;

- Possibilidade de impacto pessoal: a percepção de um risco será maior se um indivíduo ou pessoas a ele relacionadas são atingidos por suas consequências;

- Custo-benefício: se é percebido algum benefício de determinado comportamento ou ação, seu risco associado será menor do que no caso onde o benefício não é percebido;

- Confiança: quanto menor a confiança nas autoridades encarregadas de gerenciar os riscos, maior será o cuidado e o conhecimento das pessoas sobre os riscos;

- Lembranças: a experiência pessoal pode determinar a importância que os indivíduos dão aos riscos e a atitude dos indivíduos diante de certos riscos;

- Extensão em espaço e tempo: eventos potencialmente catastróficos são percebidos como mais arriscados que outros mais comuns, como acidentes de trânsito;

- Efeito sobre a segurança e a propriedade pessoal: a percepção do risco será maior se ele afetar diretamente interesses básicos e valores pessoais;

- Imparcialidade: os indivíduos obrigados a encarar riscos maiores devem ter acesso a benefícios justos por isto; 
- Comunicação: quanto melhor o processo de comunicação entre a comunidade e as autoridades encarregadas do gerenciamento dos riscos, melhor será a percepção dos riscos pelas pessoas.

Como as atitudes dos indivíduos diante dos perigos são influenciadas por diferentes prejulgamentos (que podem ser mais ou menos otimistas), são comuns as imprecisões no processo de percepção dos riscos, o que pode levar à subestimação ou à superestimação da natureza e da magnitude destes (CEPIS, 2006 apud SAMPEDRO, 2010). Na Tabela 2.2 são apresentados elementos próprios do processo de percepção de riscos que podem influenciar a subestimação ou a superestimação do perigo.

Tabela 2.2: Elementos do processo de percepção do risco segundo os prejulgamentos pessoais realizados

\begin{tabular}{c|ll}
\hline Prejulgamento & Condições pessoais & Características do risco \\
\hline Subestimação & Julgamento otimista & Voluntário \\
& Apatia & Natural \\
& Fatalismo & Não temido \\
& & Conhecido \\
& & Controlável pelo indivíduo \\
& & Controlável por alguém confiável \\
& & Gerenciado de forma responsável \\
& Emoção & Coercitivo \\
& Temor & Industrial \\
& Percepção & Temido \\
& & Desconhecido \\
& & Controlável por outros \\
& & Controlável por alguém não confiável \\
& & Gerenciado de forma irresponsável \\
\hline
\end{tabular}

Fonte: CEPIS, 2006 apud SAMPEDRO, 2010.

O julgamento do risco depende de uma percepção individual dos resultados ou dos valores esperados e do contexto sociocultural. Outro resultado do estudo realizado por Renn (1998) também mostra que as pessoas rejeitam o risco quando a média das possíveis perdas é alta, enquanto são propensos ao risco se percebem que a média dos ganhos pode ser alta. Foram identificadas, também, algumas tendências pessoais a partir de informação sobre probabilidades, mostradas na Tabela 2.3: 
Tabela 2.3 Tendências intuitivas na percepção do risco

\begin{tabular}{c|l}
\hline Tendência & \multicolumn{1}{c}{ Descrição } \\
\hline Avaliabilidade & $\begin{array}{l}\text { Eventos que são avaliáveis na mente das pessoas são imediatamente } \\
\text { considerados mais prováveis que aqueles que são mentalmente } \\
\text { menos avaliáveis. } \\
\text { Efeito assegurador }\end{array}$ \\
$\begin{array}{l}\text { Probabilidades se ajustam às rotinas cognitivas ou à confiabilidade } \\
\text { percebida na informação. } \\
\text { Eventos raros experimentados pessoalmente ou associados com } \\
\text { propriedades de outro evento são priorizados à informação sobre } \\
\text { probabilidades ou frequência relativa ao se fazer predições ou } \\
\text { inferências sobre probabilidades. }\end{array}$ \\
\hline
\end{tabular}

Fonte: RENN, 1998 apud SAMPEDRO, 2010.

Os estudos de percepção de riscos têm como principal objetivo explicar as diferentes reações dos indivíduos diante de determinados riscos e as discrepâncias entre essas reações. As pesquisas mostram que as limitações no entendimento dos processos probabilísticos, a parcialidade da mídia, experiências pessoais confusas e ansiedade e o estresse pessoal podem levar a negar a incerteza, as estimativas erradas dos riscos e a fazer julgamentos sobre fatos sem se ter a certeza necessária.

Assim sendo, CEPIS (2006) apud Sampedro (2010) alerta que, apesar da frequente discordância entre avaliação de risco pelo público e por especialistas, estes ainda são propensos aos mesmos prejulgamentos que pessoas normais, sobretudo quando estes estão em situações que pedem intuição, sem o subsídio representado pelos dados. Na Tabela 2.4 são mostradas as diferenças entre os processos de percepção de riscos em especialistas e no público em geral.

A emoção tem um papel importante na percepção do risco, em seus efeitos e no comportamento do indivíduo, e influencia de maneira diferente segundo as características das pessoas (idade, gênero etc.). A população jovem, por sua vez, é caracterizada por perceber menos os riscos, em especial no trânsito, já que eles costumam superestimar suas habilidades para dirigir, enquanto subestimam os riscos associados às características da via ou às condições do meio ambiente. 
Tabela 2.4: Características da percepção do risco segundo o tipo de avaliador.

\begin{tabular}{l|l}
\hline Tipo de Indivíduo & Características \\
\hline Especialistas & Embasada na avaliação do risco \\
& Objetiva \\
& Analítica \\
& Racional \\
Público em geral & Embasada no risco real \\
& Embasada na percepção do risco \\
& Subjetiva \\
& Hipotética \\
& Emocional \\
& Irracional \\
\hline
\end{tabular}

Fonte: CFIA, 2005 apud SAMPEDRO, 2010.

A percepção do risco pelos motoristas pode ser definida como a habilidade destes para se anteciparem a situações perigosas que se apresentam na estrada, sendo um dos aspectos relacionados com a condução dos veículos, o que pode influenciar no risco de ocorrência de acidentes. Wetton et al. (2010) expõe que a percepção do risco é uma habilidade complexa que envolve um número variado de componentes, um processo cujos passos, dependentes uns dos outros pode ser resumido de tal forma:

- Os motoristas devem registrar a existência dos eventos que constituam riscos potenciais;

- Os motoristas devem, então, julgar se a trajetória ou a natureza de qualquer dos eventos e a de seu próprio carro têm o potencial de causar um conflito;

- Os motoristas devem, então, verificar se o evento requer uma resposta adequada. Este último passo implica na decisão dos condutores se o conflito é suficientemente provável para ser considerado como um perigo.

Para finalizar, os principais fatores envolvidos especificamente na percepção do risco no trânsito estão associados à personalidade do motorista, à sua atitude, ao seu comportamento e ao nível de exposição ao tráfego. 


\subsection{ABORDAGEM SOBRE OS ACIDENTES DE TRÂNSITO}

De acordo com a evolução das pesquisas e do conhecimento sobre os acidentes de trânsito, diferentes tendências de análise foram surgindo. Os acidentes surgiram como um problema social a partir dos anos 1950. Na década seguinte- espalhou-se uma abordagem de que as medidas na segurança viária deveriam priorizar a redução do número e da gravidade dos acidentes, surgindo então uma formulação de critérios de efetividade equivalentes para avaliar ações de mitigação (FARIA e BRAGA: 2004).

No final da década de 1960 surgiu o paradigma de que o descumprimento da lei ou a sua negligência eram elementos que explicavam a ocorrência dos acidentes e, consequentemente, a solução em longo prazo seria apenas com a modificação dos comportamentos (FARIA e BRAGA: 2004), ou seja, criou-se a cultura de que o homem é o responsável e que precisa se adaptar à tecnologia do automóvel para não se envolver em acidentes de trânsito.

Segundo Faria e Braga (2004), por muito tempo houve a tendência de concentrar os esforços e as pesquisas com foco no fator humano como principal responsável pela ocorrência de acidentes, investindo-se recursos em medidas focadas na melhoria do comportamento dos usuários na via. No entanto, o aumento dos impactos econômicos e sociais dos acidentes nesse período refletiu que a segurança nas vias é uma questão muito mais complexa do que simplesmente apelar para a responsabilidade dos usuários.

Desde então, novas abordagens para o tratamento da segurança viária, baseadas no gerenciamento de riscos e implantação de estratégias preventivas vêm sendo estudadas, enfatizando ações destinadas à redução de riscos associados aos componentes viário e veicular, visando ambientes viários que propiciem a mitigação das falhas humanas e, por conseguinte, que os acidentes dependam menos do fator humano (IMT: 2002; SAMPEDRO e FOGLIATTI: 2005).

O gerenciamento de riscos é a estrutura de administração por meio da qual qualquer entidade consegue tratar e controlar de maneira mais objetiva os riscos, bem como as responsabilidades e os danos associados aos acidentes. Schlechter (1995) define gerenciamento dos riscos como o processo de gerência que tem por finalidade a proteção de pessoas, de ativos e de lucros ao evitar ou minimizar as perdas potenciais decorrentes dos 
riscos, bem como a criação e administração de fundos para cobrir eventuais perdas, no caso de acontecer acidentes.

Existem cinco elementos comuns num programa de gerenciamento de riscos: identificação do risco, avaliação do risco, tratamento ou manejo do risco, implantação do método de intervenção escolhido e monitoramento e revisão contínua do programa (WALTHER: 1992 apud ORWEN e WILSON: 2001).

Devido aos importantes investimentos para melhorar as condições de segurança das vias e dos veículos e, como, geralmente, os recursos são escassos, a adoção deste enfoque encontra certa resistência. Entretanto, os países que conseguiram reduzir de forma contínua e notável seus índices de acidentes são aqueles que investiram quantidades importantes de recursos na redução dos riscos relacionados com os componentes viário e veicular, como o caso dos países da União Europeia (Figura 2.3):

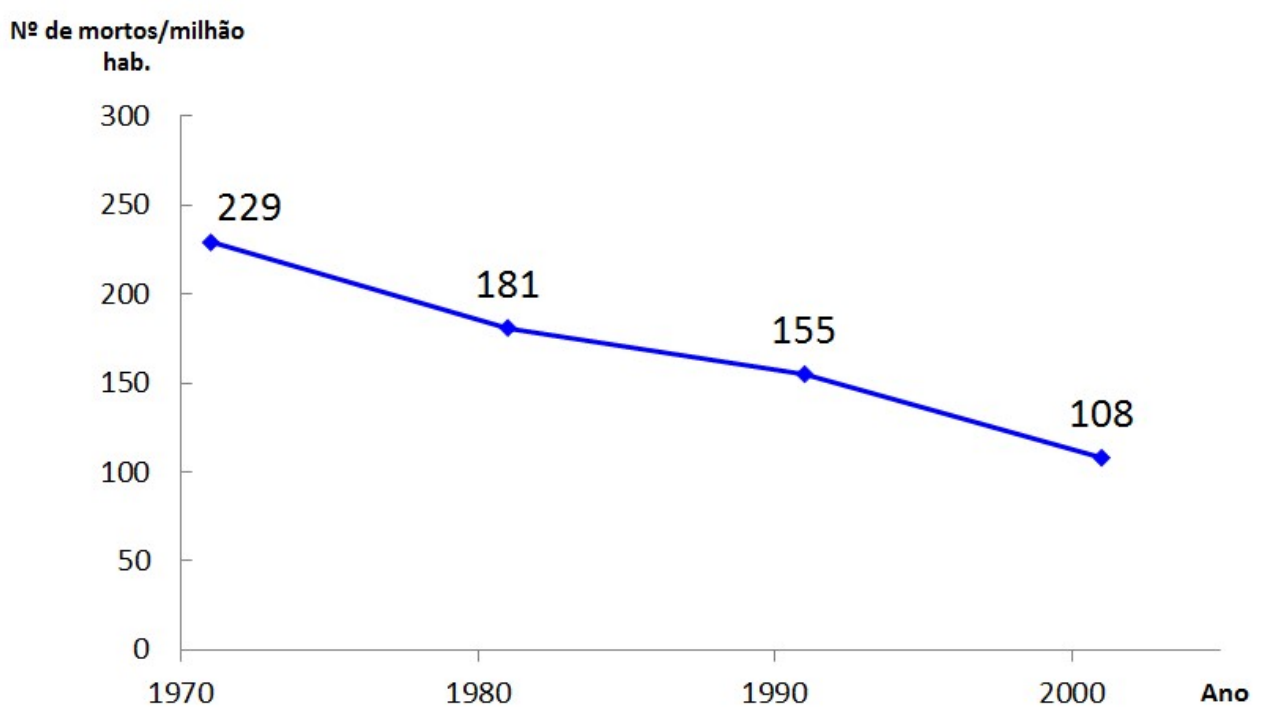

Figura 2.3: Número de mortos em acidentes de trânsito para cada milhão de habitantes na UE. Período 1970-2000. Fonte: adaptado de Comissão Europeia (2003).

\subsection{ESTRATÉGIAS PROATIVAS OU PREVENTIVAS}

O gerenciamento da segurança viária (GSV) surgiu como alternativa aos programas de segurança viária baseados em ações pontuais e isoladas. O GSV é um processo sistemático que visa à redução do número e da severidade dos acidentes, no qual a segurança deve ser tratada de forma explícita em todas as fases de um empreendimento viário (FHWA: 2001). Seu objetivo principal é assegurar a identificação, avaliação e implantação adequadas de 
todas as oportunidades viáveis de melhorar as condições de segurança em todas as etapas do empreendimento (planejamento, projeto, construção, manutenção e operação).

Dois focos claramente definidos formam a base das iniciativas para o GSV: as estratégias reativas ou corretivas e as estratégias proativas ou preventivas. Ambas implicam ações sobre os diferentes componentes que influenciam na acidentalidade.

O tratamento de segurança do trânsito, geralmente, enfatiza a diminuição de acidentes pela adoção de intervenções corretivas em locais com grande concentração de acidentes, chamados de pontos críticos. No entanto, é reconhecido que, ultimamente, vem crescendo a importância de tratar a segurança viária de maneira preventiva (NODARI e LINDAU: 2001).

Enquanto as ações corretivas procuram resolver problemas revelados pela ocorrência visível de acidentes em determinados pontos da rede viária, as medidas proativas visam atenuar situações potenciais de risco presentes na via, evitando possíveis acidentes. O propósito explícito das ações de segurança preventivas é a estimativa dos riscos e dos componentes desse risco.

A adoção de estratégias preventivas leva a muitos resultados, indo desde a diminuição das despesas pelos acidentes evitados, até a eliminação dos gastos decorrentes das obras de correção que não precisam ser realizadas devido à diminuição do número de pontos críticos. Apesar das medidas corretivas se fazerem necessárias e urgentes frente ao panorama atual dos acidentes de trânsito em muitos países, Nodari (2003) considera que as ações preventivas trarão avanços notáveis que serão alcançados na melhoria da segurança viária. 


\section{RELAÇÃO DAS CARACTERÍSTICAS DA VIA E A SEGURANÇA DO TRÁFEGO}

Embora o fator humano tenha um maior peso na origem da ocorrência de acidentes, nem sempre a solução com melhor relação custo-benefício é na atuação dessa contribuição. Nodari (2003) relata que a solução mais eficiente pode não estar relacionada com a principal "causa" do acidente, podendo até mesmo recair sobre um componente diferente daquele que o motivou. Ao analisar a falha do motorista em lidar com o ambiente viário, normalmente costuma-se a atribuir o acidente à falta de habilidade do motorista.

É imensamente importante a relação entre as características das vias urbanas e rodovias e a ocorrência de acidentes. O conjunto viário pode vir a criar situações onde induza os motoristas a errar. As proporções de acidentes com motoristas e pedestres pouco experientes no trânsito é muito grande, porém, em certos momentos, o ambiente também propicia condutores habilidosos e cautelosos a cometer erros ao apresentar situações inesperadas.

Desde 1960 são realizados estudos associados aos fatores viários relacionados ao projeto de engenharia e aos fatores ambientais que afetam a quantidade e a qualidade dos acidentes de trânsito. Em 1963, a Automotive Safety Foundation (ASF) analisou e resumiu muitas questões relacionadas aos diferentes efeitos das características viárias sobre a segurança dos usuários, como, por exemplo, volume de tráfego, seção transversal, alinhamento, interseções, travessias de ferrovias, velocidade, pedestres, estacionamento e iluminação (SAMPEDRO: 2010).

No entanto, os conhecimentos atuais sobre as relações entre os elementos da infraestrutura das vias e a segurança rodoviária ainda são limitados (PICADO: 2005). Por conseguinte, pode-se perceber que há três grupos de fatores ao classificar a relação de influência: um primeiro grupo de características onde já se pode quantificar os acidentes; um segundo, no qual se reconhece apenas a direção da influência sobre a ocorrência dos acidentes, desconhecendo-se, assim, regras para a previsão de quantificação de acidentes; um terceiro, cujas influências ainda não foram estudadas. Uma avaliação quantitativa do número de acidentes se faz necessária para a identificação da relação entre os vários elementos da via e o número de acidentes (PARK et al.: 2010). 
Realmente existe uma ligação entre a infraestrutura viária e a segurança de tráfego e esta pode ser apresentada num esquema, como mostrado na Figura 3.1. Dessa maneira, percebese que a infraestrutura está intimamente ligada com a segurança através de seus elementos mediadores de tráfego. As normas influenciam a segurança à medida que os volumes de tráfego são gerados e as velocidades estabelecidas. O projeto rodoviário impacta através das velocidades que ele permite e dos volumes de tráfego que é gerado. Vale a pena ressaltar que as velocidades de tráfego são decisivas na severidade dos acidentes.

Segundo o TRB (1987) apud Nodari (2003) “as características geométricas da via afetam as condições de segurança de diferentes maneiras", influenciando:

- A habilidade do motorista em manter o controle do veículo e identificar situações e características perigosas;

- A existência de oportunidades de conflitos, tanto em relação à quantidade quanto ao tipo;

- As consequências de uma saída de pista de um veículo desgovernado;

- O comportamento e a atenção dos motoristas.

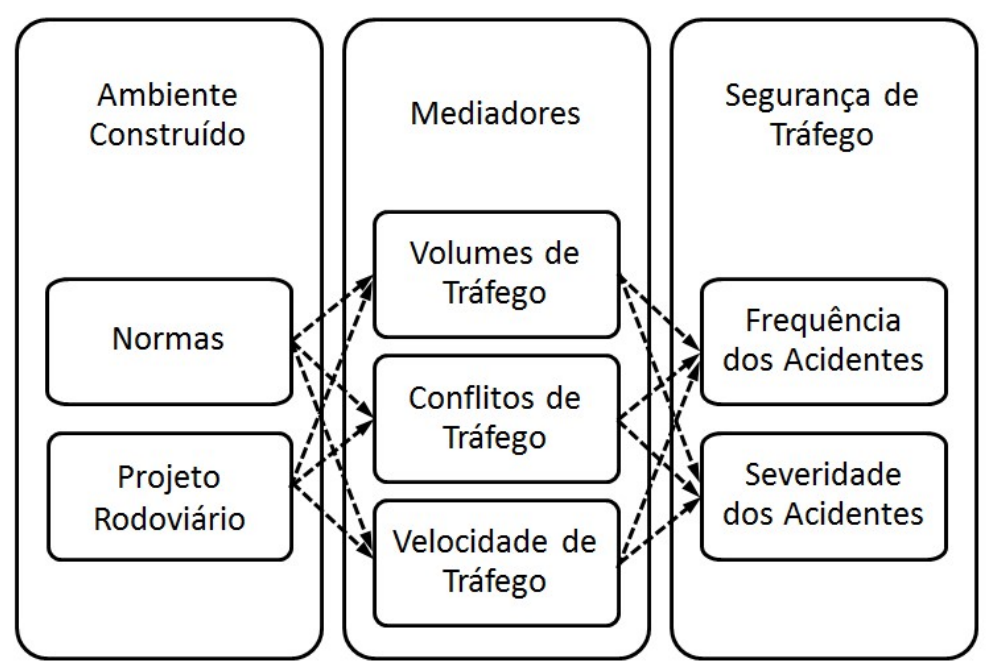

Figura 3.1: Estrutura conceitual de vinculação entre meio ambiente construído para segurança no trânsito.

Fonte: Adaptado de Ewing e Dumbaugh (2009). 
Acredita-se que a combinação dos diferentes fatores viários deve permitir aos usuários a utilização e interação de forma segura, confortável, simples e clara, permitindo assim a redução das consequências e correções dos eventuais erros ocasionados por estes (TRB: 1987; NCHRP: 1997; IMT: 2002). O bom desempenho do motorista depende de características como geometria da via, projetos de sinalização e uma clara percepção de quem tem a prioridade no trânsito. Para Nodari (2003), o projeto viário deve oferecer condições para o motorista, após cometer um erro, retomar o controle do veículo na iminência do acidente e consiga evitá-lo e, caso este acontecimento seja inevitável, a rodovia deva proporcionar ao condutor condições para que as consequências não sejam graves.

Projetos viários de alto nível resultam em um aumento da velocidade da via e facilitam a tarefa do motorista, fazendo com que este reduza o seu nível de atenção. A combinação desses dois aspectos revela resultados incoerentes, quando se constata que a melhora nas características das vias aumenta o número dos acidentes (NOLAND: 2003).

\subsection{TraÇAdo}

As características do alinhamento horizontal e vertical são de extrema importância para que a via ofereça conforto, comodidade e segurança à circulação dos usuários. O motorista se submete a um estresse permanente quando a via demanda esforço e habilidade excessiva, com um traçado sinuoso demais, com um exagerado número de curvas horizontais, e/ou com pequenos raios de curvatura. Esse efeito no condutor também acontece quando ocorrem situações de perfil irregulares, quando um trecho de via é assentado sobre um terreno ondulado.

Por outro lado, um traçado com a presença de trechos retos muito longos pode causar monotonia na direção, tendo um efeito contrário ao que se deseja, provocando cansaço, tédio e distração (CETRA: 2003). Um bom projeto de alinhamento prioriza o uso de curvas com raios de curvaturas grandes e com transições amplas e suaves.

É imprescindível, portanto, a coordenação entre os alinhamentos vertical e horizontal, conferindo à via características superiores de segurança, de conforto, de comodidade e de aparência. A falta dessa interação pode acentuar os defeitos do traçado ou do perfil e, além disso, pode anular aspectos favoráveis de um ou outro, considerados isoladamente. 
É interessante, também, que meio ambiente e traçado viário não sejam hostis um ao outro e sejam, de certo modo, adequados um ao outro. Uma complementação entre a geometria e o entorno deve proporcionar uma condução clara e consistente, evitando que, em determinados pontos, haja a surpresa do condutor e a tomada de decisão errada. Essa situação pode ser observada na Figura 3.2, em que na imagem à esquerda exibe-se a falta de alinhamento das defensas, e da via e a da direita mostra a falta de visibilidade do motorista com uma curva vertical. Caso esta situação não seja possível de ser evitada, o motorista deve ser alertado com antecipação e orientado para agir corretamente.
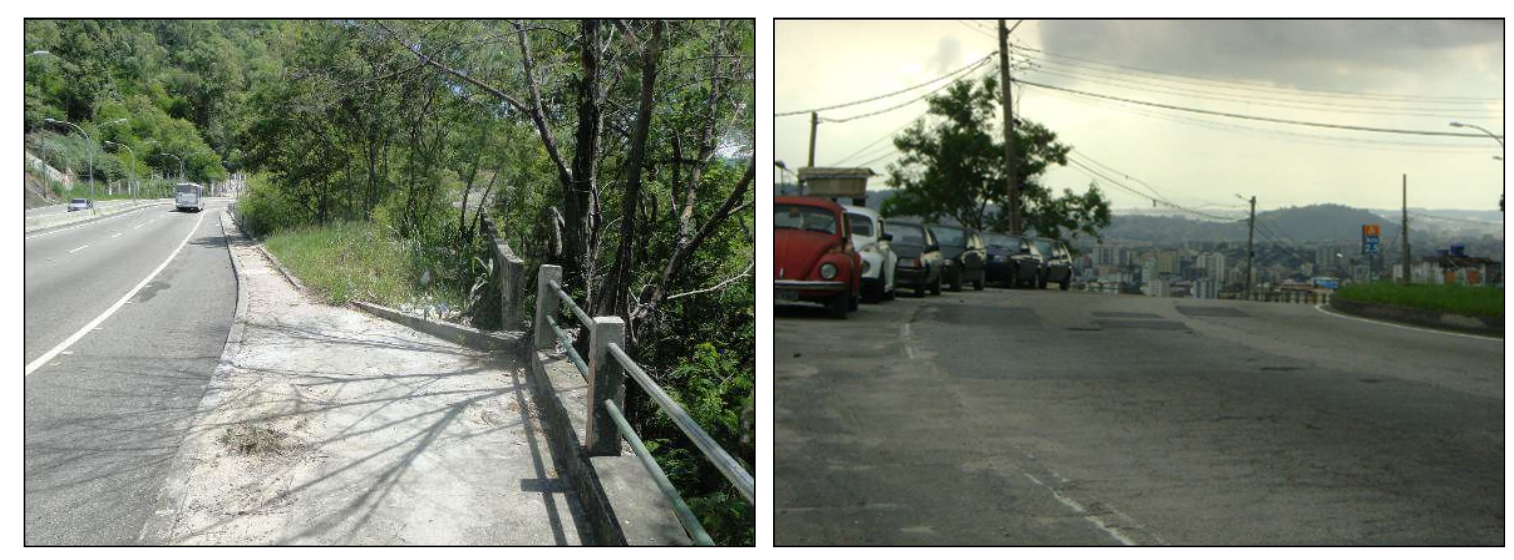

Figura 3.2: Locais problemáticos de interação traçado/entorno complexa.

\subsubsection{Alinhamento Horizontal}

Ao realizar a comparação, o número de acidentes entre trechos curvos e tangentes, percebese que o número de acidentes em trechos curvos é 1,5 a 4 vezes maior do que os que correm em trechos em tangentes. A severidade dos acidentes em curvas também é maior (AASHTO: 1997; NODARI: 2003).

Entre os acidentes mais frequentes em curvas horizontais estão os capotamentos, as colisões frontais e laterais, os incidentes no período noturno, os choques contra obstáculos situados nas laterais da via e os acidentes envolvendo motoristas alcoolizados (NODARI: 2003; SAMPEDRO: 2010). 
Diversos estudos que investigaram a relação existente entre o alinhamento horizontal e os acidentes identificaram o volume de tráfego e as características de projeto da curva como influências pertinentes à ocorrência de acidentes e $\mathrm{m}$ curvas horizontais. Dentre as características do projeto de curva, estima-se que o grau de curvatura é o que exerce maior influência no potencial de ocorrência de acidentes (OGDEN: 1996).

Além disso, Sampedro (2010) afirma que curvas fechadas precedidas por tangentes longas apresentam elevados índices de acidentes, devido, entre outras coisas, à surpresa dos motoristas ao enfrentar situações inesperadas.

Outros dois fatores que têm efeito na segurança em curvas horizontais são a superlargura e a superelevação, ou seja, o alargamento e elevação dos bordos da pista, fazendo com que a segurança e a comodidade dependentes das características da seção transversal permaneçam inalteráveis quando se compara aos trechos retos (TRB: 1987).

A superlargura reduz o estresse dos motoristas de forma considerável ao passar por outros automóveis no interior da curva e, também, o risco de colisões transversais. A superelevação adequada contribui para aumentar o conforto dos motoristas e passageiros durante o percurso pelas curvas horizontais.

\subsubsection{Alinhamento vertical}

Em uma relação de menor magnitude que as curvas horizontais, o alinhamento vertical também provoca situações de comprometimento da segurança viária (GAO: 2003). Os principais problemas do motorista ao transcorrer regiões com defeitos no alinhamento vertical são: a diminuição da distância de visibilidade da via, a inclinação das rampas, a natureza dos obstáculos situados na zona de visibilidade restringida e os problemas de drenagem em curvas inclinadas longas e pouco profundas (TRB: 1987). É extremamente perigosa a realização de ultrapassagens nesses locais e não é recomendada a construção de curvas verticais sucessivas.

A distância de visibilidade adequada é essencial para garantir a percepção clara e antecipada o suficiente para que o motorista consiga reagir corretamente e com segurança aos obstáculos ou situações que surgirem à sua frente na via. 
Quando se fala em acidentes devido a rampas percebe-se que a frequência em trechos em declives é $63 \%$ maior do que em aclives, o que é coerente com um aumento de velocidade dos veículos ao descerem a rampa. Além disso, o aumento de velocidade provoca uma redução de tempo para a tomada de decisões, o que resulta num acréscimo no número de acidentes (SAMPEDRO: 2010).

Por outro lado, nas rampas ascendentes, o trânsito de veículos de grande porte, especialmente os caminhões, ao diminuírem de velocidade devido à inclinação da rampa, tende a aumentar o número de ultrapassagens de veículos de menor porte, provocando mais acidentes (NODARI: 2003). Ou seja, em rampas acentuadas há aumento do número de acidentes, sendo maior nos declives.

\subsubsection{Integração entre alinhamentos verticais e horizontais}

Para uma situação de segurança desejável deve haver uma combinação dos alinhamentos horizontal e vertical sem que haja influência na alteração em aspectos como a distância de visibilidade e velocidade operacional. Como um todo, a combinação dos alinhamentos da via urbana ou da rodovia deve permitir ao condutor o tráfego com uma velocidade praticamente constante ao longo da rodovia sem que o ambiente permita situações de surpresas aos motoristas.

\subsection{SEÇÃo TRANSVERSAL}

A seção transversal da via exerce um efeito importantíssimo sobre a segurança de tráfego, seja em suas características geométricas, seja em seus tipos e condições. Na Figura 3.3 podese visualizar vias que apresentam problemas quanto a seção transversal, a Figura 3.3(a) mostra problemas com a delimitação das faixas de rolamento na sinalização horizontal, na Figura 3.3 (b) o problema de canteiro central é apresentado mostrando que não existe segregação nos sentidos da pista, a Figura 3.3(c) apresenta um problema com desnível da pista com o terreno natural junto com a falta de um acostamento e na Figura 3.3 (d) são apresentados postes instalados na sarjeta da pista. 
(a)

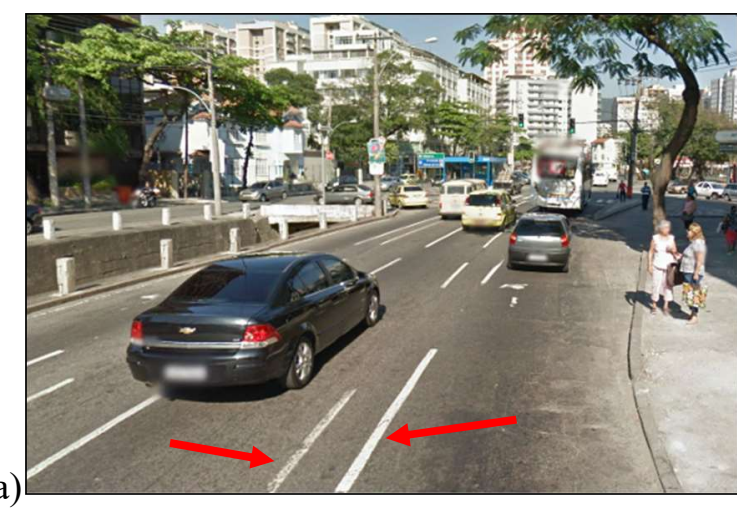

(c)

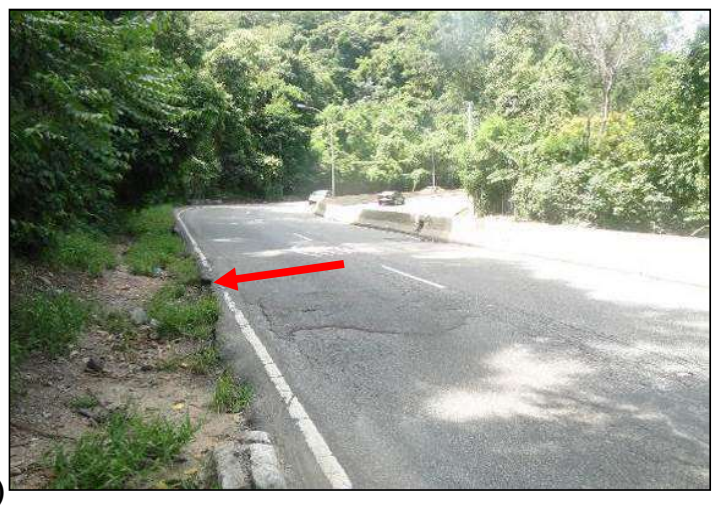

(b)

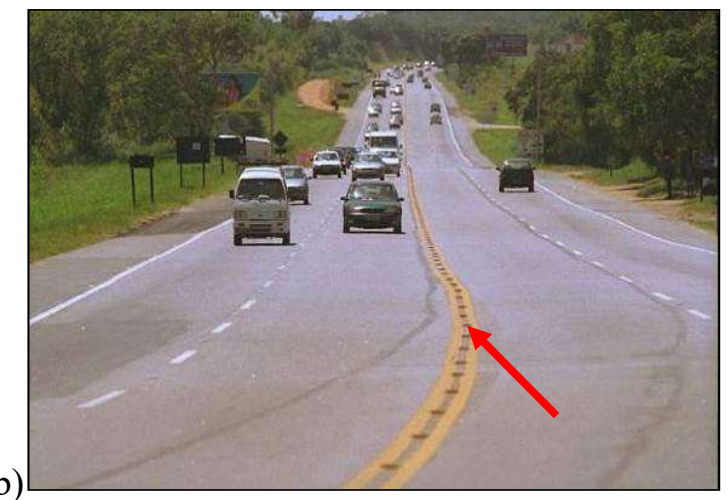

(d)

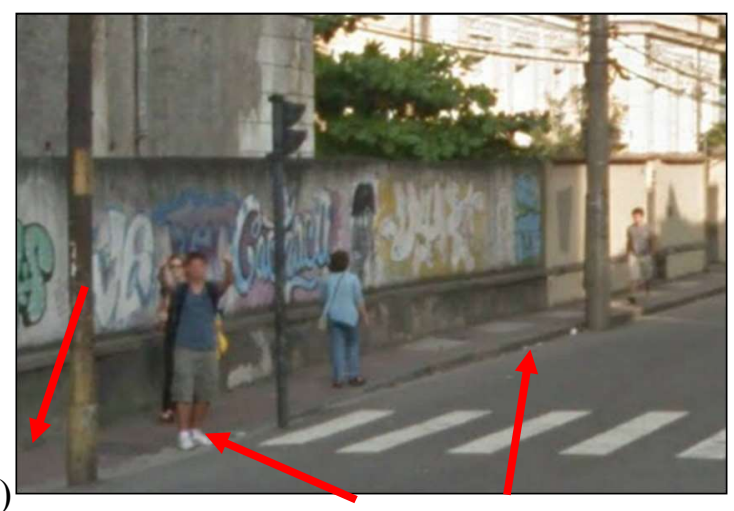

Figura 3.3: Locais problemáticos em função da seção transversal. Fonte: Google Maps (2015).

\subsubsection{Faixas}

A adoção de faixas mais largas tem efeito duplo na relação com a segurança de tráfego. Primeiramente, ao aumentar as faixas, o espaçamento lateral entre os veículos também acontece, fornecendo um maior espaço para a acomodação em pequenos desvios. O segundo efeito é que ao estabelecer faixas mais largas, há um maior espaço para o condutor para corrigir manobras (NCHRP: 2007).

Além disso, devem-se considerar o volume de tráfego e a velocidade da via como fatores de influência sobre a segurança, combinados com a largura da faixa. Ao analisar o efeito da largura das faixas, FHWA (2000a) conclui que a ocorrência de acidentes aumenta quanto maior for o volume de veículos, alcançando o maior valor quando circulam por volta de 2000 veículos/dia.

Acredita-se que, nas vias urbanas, o volume de veículos tem maior relação com a segurança sob o efeito da largura da faixa. Isso se deve ao fato de que, na cidade, existe uma maior quantidade de veículos e uma baixa velocidade de circulação. Pode-se dizer que o aumento 
da largura das faixas no ambiente urbano irá influenciar nas questões de fluidez e operação do trânsito

Todavia, ao alargar a pista de rolamento e, por conseguinte, elevar-se-á a velocidade de circulação dos veículos, pode-se chegar a outros problemas de segurança (GAO: 2003). Como exemplo, um dos mais graves, são as questões sérias de atropelamentos de pedestres.

\subsubsection{Canteiro central}

O canteiro central é o espaço utilizado para manter uma separação física, operacional, psicológica e esteticamente entre pistas de sentidos de tráfego opostos, permitindo ao condutor a retomada da direção do veículo. Também serve para separar fisicamente o tráfego em sentidos opostos, minimizando as interações e a probabilidade de acidentes mais graves (GAO: 2003). Além disso, canteiros centrais com barreiras de contenção desestimulam a travessia desordenada da via por pedestres. Os canteiros centrais mais utilizados são: (a) os largos sem barreiras físicas, (b) os estreitos com barreiras físicas ou (c) de concreto e (d)os estreitos sem barreiras físicas. Os exemplos desses canteiros são mostrados na Figura 3.4.

A utilização do canteiro central para a separação dos fluxos veiculares de sentidos opostos oferece inúmeros benefícios à segurança. Além disso, existe um efeito positivo para a segurança dos pedestres ao oferecer-lhes uma área de refúgio durante as travessias de rua e para o conforto dos motoristas ao reduzir o ofuscamento pelos faróis dos veículos que circulam em sentidos opostos no período noturno. 
(a)
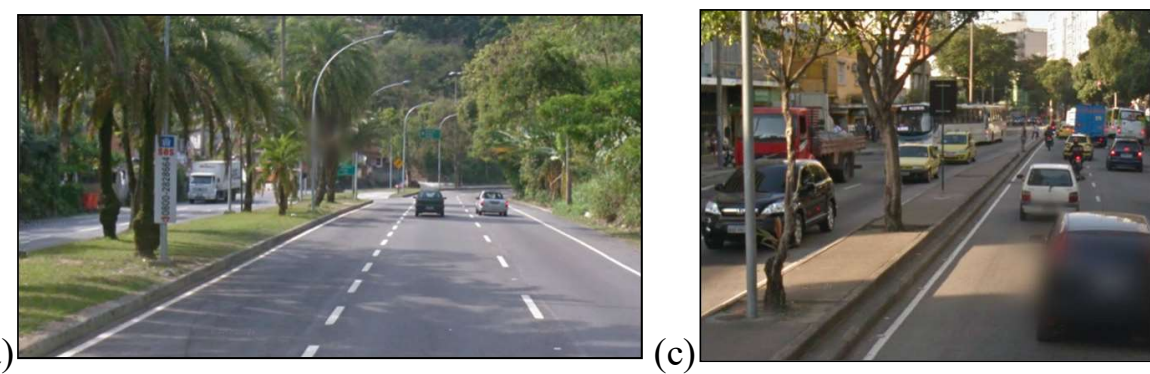

(b)
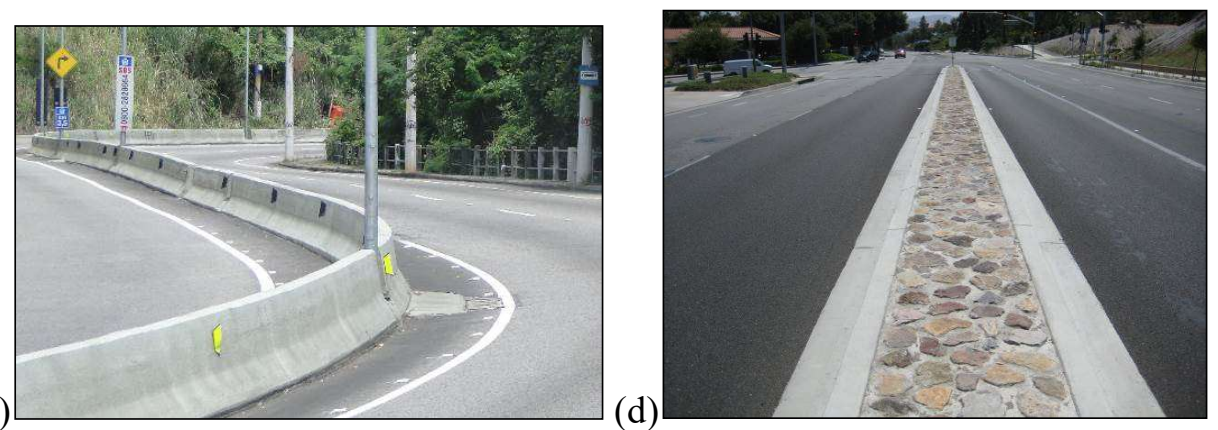

Figura 3.4: Exemplos de canteiros centrais.

Fonte: Google Maps (2015).

Canteiros mais largos favorecem um espaço suficiente para que os motoristas possam retomar o controle dos veículos desgovernados. Além disso, servem como um refúgio de proteção para os automóveis que precisam realizar retorno ou cruzar a via. A Tabela 3.1 resume os valores recomendados para a largura do canteiro central em projetos de rodovias, vias expressas e arteriais primárias.

A implantação de barreiras de contenção de concreto ou metálicas no canteiro central provoca um aumento no número total de acidentes, porém reduz de forma considerável a sua severidade, uma vez que reduz a ocorrência de colisões frontais. IMT (2002) reportou um trabalho indicando que a implantação de barreiras de contenção metálicas provocou um aumento de $14 \%$ nos acidentes sem vítimas, mas reduziu em $15 \%$ o número de acidentes fatais.

\subsubsection{Barreiras longitudinais de contenção}

As barreiras longitudinais de contenção são elementos, geralmente metálicos ou de concreto, colocados nas bordas da pista, tanto no canteiro central quanto nos limites dos acostamentos, nos locais da via com taludes altos e inclinados ou com a presença de pilares de pontes, postes, árvores ou outros obstáculos fixos perigosos, com o intuito de proteger os veículos 
desgovernados de eventuais choques. São desenhadas para amortizar os impactos laterais dos veículos e atenuar ao máximo as consequências dos acidentes.

Tabela 3.1: Largura do canteiro central

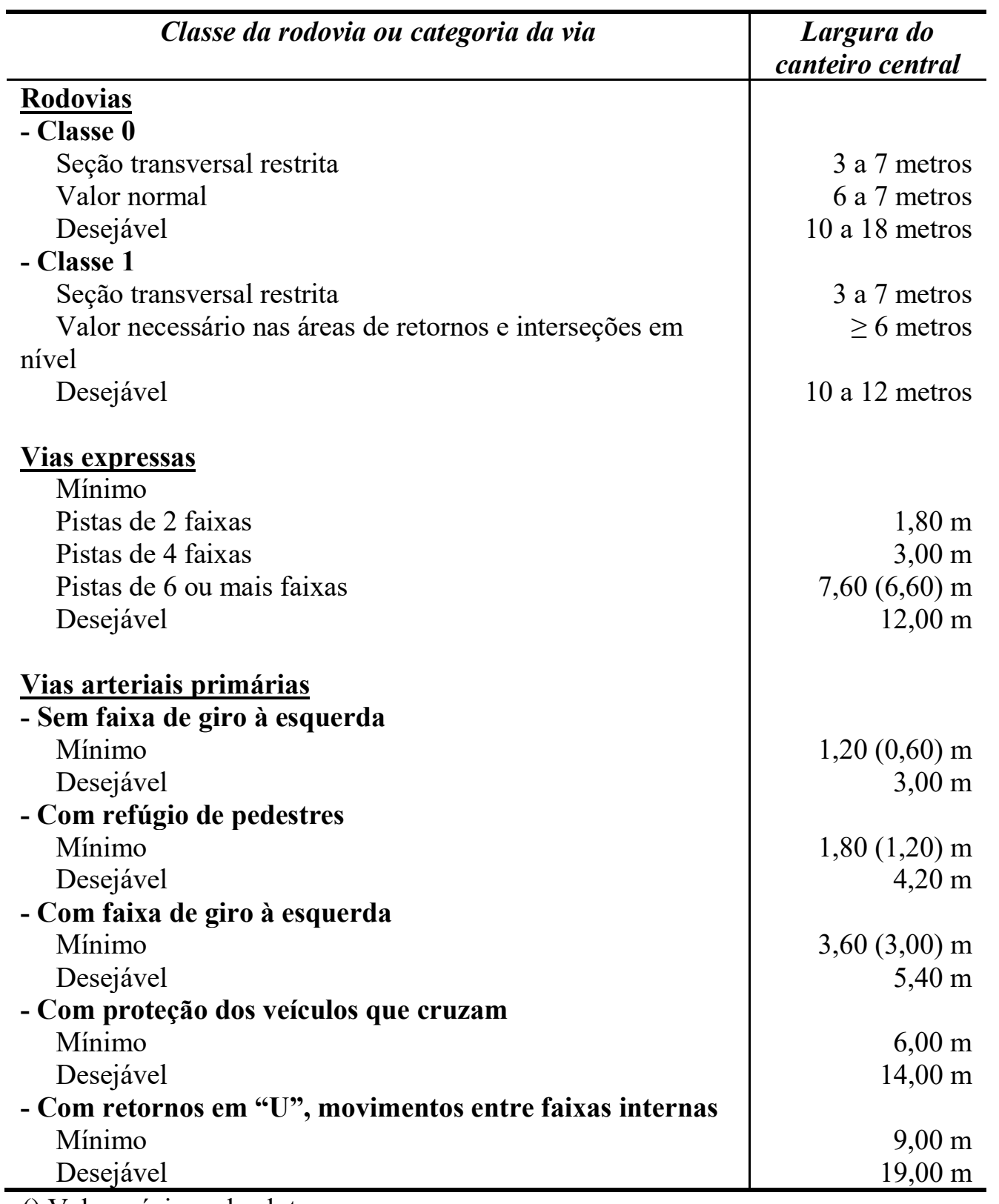

() Valor mínimo absoluto.

Fonte: DNIT (2010a) e DNER (1999).

Segundo NCHRP (1999) resultados de estudos mostram que a efetividade das barreiras longitudinais na redução de acidentes depende das condições de instalação, do material usado para sua fabricação, das características do terreno e da manutenção realizada. Os estudos consultados reportam uma diminuição do número total e da severidade dos acidentes quando são usadas as barreiras laterais, embora também constatem um aumento das colisões 
contra estes dispositivos devido ao reduzido espaço entre eles e os veículos que circulam (GAO: 2003).

\subsubsection{Acostamentos}

De acordo com NCHRP (2007) e DNIT (2010a), os acostamentos são destinados a:

- Parar ou estacionar, provisoriamente, em caso de defeito técnico do veículo ou alguma emergência;

- Servir de faixa extra de rolamento para emergências;

- Contribuir para proteção da estrutura do pavimento e dos efeitos da erosão;

- Permitir a circulação de pedestres, bicicletas e animais, quando não houver local apropriado para esse fim;

- Prover uma maior distância entre os veículos e os obstáculos laterais existentes nas proximidades da pista;

- Oferecer um espaço suficiente para que, em caso de perda de controle do veículo, o motorista consiga efetuar manobras requeridas até retornar à pista sem a ocorrência de qualquer acidente.

Dentre os fatores contribuintes na influência dos acostamentos na segurança viária estão relacionados: a largura destes, o desnível existente entre eles e a pista, o material com que foram construídos e o volume de tráfego de veículos (TRB: 1987; CETRA: 2003).

De modo geral, acredita-se que a existência da influência da largura de acostamentos está diretamente associada ao volume de tráfego. FHWA (2000a) analisa a influência da largura dos acostamentos na acidentalidade para vias com diferentes volumes de tráfego, concluindo-se que o efeito é maior na medida em que aumenta o volume de veículos.

Por outro lado, verificou-se que os acidentes que envolvem mais de um veículo aumentam na medida em que a largura do acostamento aumenta (FHWA: 1992). Segundo Ogden (1997), os acostamentos mais largos concedem ao motorista imprudente ou àqueles dirigindo em velocidade alta uma margem de segurança, permitindo ao condutor a retomada do controle do veículo a tempo. Ao mesmo tempo, há a redução da velocidade operacional da via quando se tem acostamentos mais estreitos, reduzindo a probabilidade de ocorrência de acidentes múltiplos (SHANKAR et al.: 1995). 
Ao analisar os materiais com que foram construídos, os acostamentos pavimentados têm os menores índices de ocorrência de acidentes (FHWA: 2000a; GAO: 2003). Os acostamentos de brita e gramados afetam o controle do veículo devido às desigualdades das bordas e à diferença de fricção entre a pista de rolamento e o acostamento. Estes ainda possuem uma taxa de deterioração acentuada, devido a serem afetados mais rapidamente por processos erosivos, até níveis alarmantes de comprometimento da segurança.

O último fator considerado como fonte de risco no que diz respeito aos acostamentos é o desnível com a pista. Geralmente, o efeito ocorre devido à má qualidade dos materiais, a falta de manutenção do acostamento ou os recapeamentos sucessivos da pista. O principal efeito do desnível entre a faixa de rolamento e o acostamento está associado à situação de perda do controle em que uma das rodas do veículo chega ao acostamento e há a dificuldade do condutor em retornar com segurança à pista (CETRA: 2003; NODARI: 2003).

No entanto, efeitos negativos relacionados à presença dos acostamentos surgem quando se relaciona o aumento do número de paradas dos veículos, o aumento da velocidade de circulação, o acréscimo da severidade dos acidentes e a utilização destes como faixas de circulação para realizar ultrapassagens (NHCRP: 2007).

\subsubsection{Calçadas}

Segundo o DNIT (2010a), a calçada é parte da via, normalmente segregada e em nível diferente, não destinada à circulação de veículos, reservada ao trânsito de pedestres e, quando possível, à implantação de mobiliário urbano, sinalização, vegetação e outros fins. A largura da calçada subdimensionada ao volume de pedestres que por ela passam provoca desconforto e restringe a velocidade de movimentação dos passantes.

Também se incluem no estudo da análise das calçadas as suas condições físicas, como, por exemplo, a presença de buracos e desníveis que podem causar acidentes e quedas com danos aos pedestres, levando-os a abandonarem a calçada e invadir a rua em casos extremos. Sobretudo, essa preocupação se torna crescente quando se analisa o processo de envelhecimento da cidade ou do bairro em questão. 
Ademais, devem-se incluir também outros fatores que podem ser levados em conta como o estado e altura do meio-fio e a presença dos dispositivos de acessibilidade para pessoas com mobilidade reduzida.

\subsubsection{Faixas auxiliares de ultrapassagem}

Benefícios operacionais e de segurança são introduzidos com a implantação de faixas auxiliares, uma vez que $10 \%$ dos acidentes rodoviários com vítimas são associados às manobras de ultrapassagem realizadas (IMT: 2002) em vias com alto volume de tráfego ou com uma grande presença de veículos lentos.

AASHTO (2001) descreve que as oportunidades de ultrapassagem podem ser facilitadas por meio de uso de diferentes faixas adicionais: as faixas para ultrapassagens em aclives (climbing lanes), as utilizadas em terrenos planos (passing lanes), trechos com quatro faixas (short four lane section), as faixas adicionais curtas utilizadas para o veículo de velocidade baixa se retirarem apenas em tempo do veículo com velocidade superior ultrapassá-lo (turnouts) e os trechos onde os acostamentos podem ser utilizados como faixas de ultrapassagem (shoulder use section). Estas faixas são projetadas e implantadas em função das possibilidades de ultrapassagens e dependem da distância de visibilidade e das brechas existentes entre os veículos que circulam em direção oposta.

Estudos reportados no IMT (2002) informam a diminuição de $35 \%$ do total de acidentes e de $25 \%$ dos acidentes com vítimas depois da instalação de faixas auxiliares em rodovias da Austrália, bem como a redução de $10 \%$ a $20 \%$ dos acidentes quando implantadas terceiras faixas em aclives de $3 \%$ a $4 \%$ e de $20 \%$ a $40 \%$ em rampas mais pronunciadas.

A implantação de faixas para ultrapassagens deve ser evitada na proximidade das zonas urbanas, em trechos que apresentam interseções com alto volume de tráfego e em segmentos com alta densidade de acessos. 


\subsection{Pavimento}

A estrutura do pavimento e as condições de sua superfície são essenciais para garantir o conforto e a segurança dos usuários do sistema de trânsito. O pavimento deve ser projetado de forma a suportar os veículos que circulam na via e garantir a segurança contra derrapagem dos automóveis. Ao mesmo tempo, o período de projeto concebido para sua utilização deve ser tal que os custos de manutenção sejam viáveis.

\subsubsection{Estrutura}

A deficiência da capacidade estrutural dos pavimentos consiste na maior fonte de riscos, sobretudo, em países em desenvolvimento. A presença de buracos, ondulações, desníveis, trincas e fissuras em pavimentos com problemas estruturais é frequente, como mostrado na Figura 3.5. As causas destas condições estão relacionadas, principalmente, na ação conjunta do tráfego de veículos pesados com cargas superiores às permitidas e da água da chuva. Unido a esses fatores, também se têm as deficiências em manutenção.
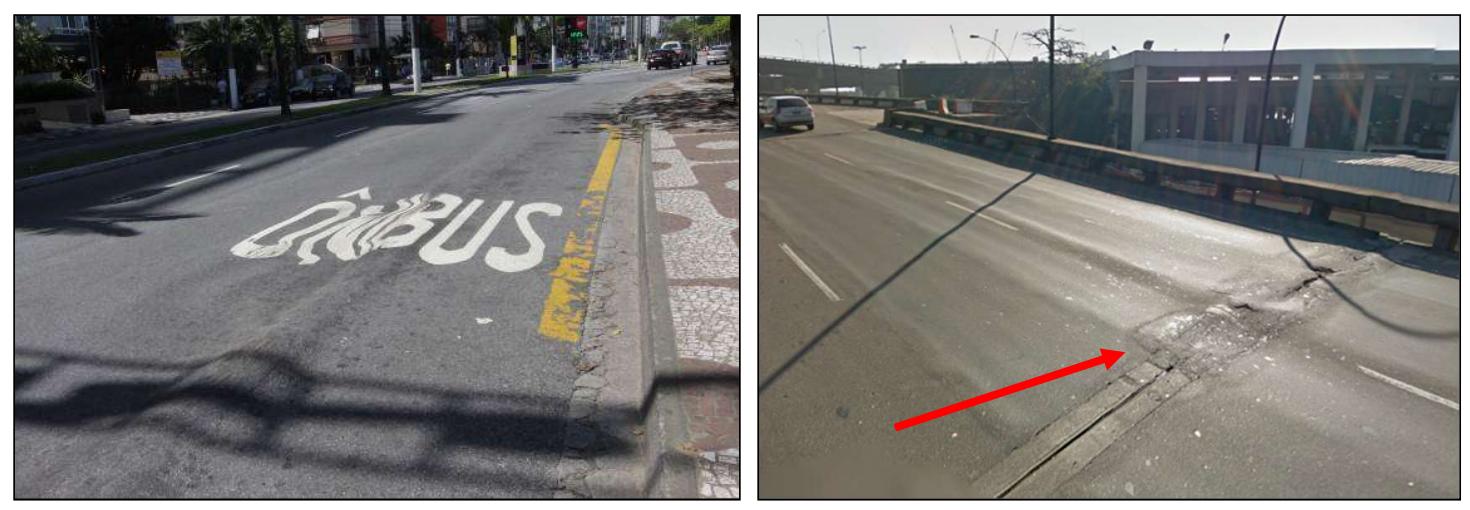

Figura 3.5: Locais com desníveis e deformações no pavimento. Fonte: A Tribuna (2014) Google Maps (2015).

Esses defeitos na pista fazem com que o motorista seja obrigado a realizar manobras de direção ofensivas e/ou reduções bruscas de velocidade. Algumas situações nas quais buracos maiores ou ondulações frequentes passem despercebidos pelo motorista podem fazer com que o condutor perca o controle do carro ou algum componente do veículo possa quebrar (CETRA: 2003).

\subsubsection{Superfície}

A superfície do pavimento deve garantir atrito necessário para a segurança de tráfego. $\mathrm{O}$ controle e a capacidade de frenagem do veículo são bastante comprometidos quando o 
automóvel é posto em um ambiente em que os níveis de atrito entre a superfície da via e os pneus são insuficientes, aumentando os índices de derrapagem dos veículos.

É importante ressaltar que, nos casos em que o pavimento se encontra molhado, a influência da textura da superfície é um dos principais fatores na causa de acidentes. Segundo Maia (1995), a medida responsável pela resistência ao deslizamento da pista é o coeficiente de atrito, o qual é dependente de vários fatores, entre os quais se destacam as características da camada de rolamento, dos pneus, a velocidade de operação, e a quantidade de água e de sujeira superficiais. São relatadas como acidentes mais comuns as colisões traseiras e transversais nas interseções e nas curvas horizontais.

Outro fator causador de acidentes está relacionado com a execução do revestimento asfáltico que, quando a mistura é superaquecida, pode comprometer toda a vida útil de projeto da via. Ao ultrapassar os limites máximos de temperatura de mistura na produção da massa asfáltica, alguns componentes do ligante asfáltico oxidam, envelhecendo a mistura. Outra consequência proveniente da má execução e manutenção é a exsudação do ligante na superfície do pavimento ou o vazamento de óleo na pista, obrigando a empreiteira a realizar a correção através de aplicação de areia sobre a camada asfáltica. Muitas vezes os operários não varrem a areia, o que ocasiona a diminuição do atrito dos pneus com a superfície do pavimento. Problemas derrapagem tanto com acúmulo de areia como a de água na superfície do pavimento podem ser vistas na Figura 3.6:
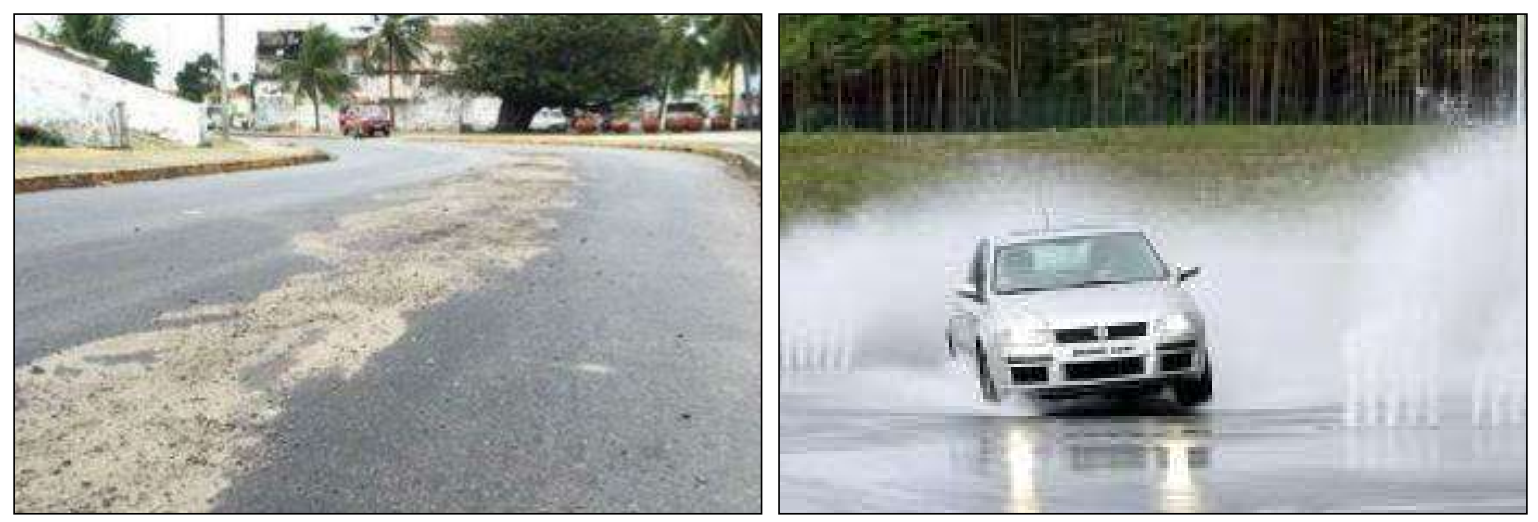

Figura 3.6: Problemas na superfície do pavimento. Fonte: JC online (2015) e Hoje em Dia (2015).

Vale ressaltar que se deve realizar uma avaliação das condições do pavimento antes de selecionar a atividade de manutenção e/ou reabilitação mais adequada. O TRB (1987) relata 
os diferentes efeitos da reabilitação do pavimento. Alguns estudos revelam um aumento de 10\% no número de acidentes em condições de pavimento seco, aparentemente devido ao ganho de percepção da segurança do motorista e, por conseguinte o aumento da velocidade de circulação. No entanto, com o pavimento molhado, é perceptível a redução no número de acidentes, provavelmente devido ao mesmo ganho de segurança do motorista e rápida retomada do controle.

\subsection{SinalizaÇão}

De acordo com DNIT (2010b), a sinalização permanente, composta em especial por sinais em placas e painéis, marcas viárias e dispositivos auxiliares, constitui-se num sistema de dispositivos fixos de controle de tráfego que, ao serem implantados nas rodovias, ordenam, advertem e orientam os seus usuários. A sinalização deve ser projetada e localizada a fim de conquistar a atenção do usuário, permitindo-lhe um tempo de reação adequado.

A sinalização rodoviária tem evoluído com certa regularidade, na medida em que os materiais empregados vão sendo aperfeiçoados e os métodos de implantação modernizados. Os usuários, também passam a compreender melhor não só as mensagens transmitidas pela sinalização como também sua importância para a segurança das viagens (SENÇO: 1997).

\subsubsection{Sinalização vertical}

A sinalização vertical é composta pela comunicação visual, por meio de placas, painéis ou dispositivos auxiliares, situados em posição vertical, suspensas sobre a via ou implantadas à margem, que têm como finalidade a regulamentação do uso da via, a advertência para situações potencialmente perigosas e o fornecimento de mensagens e orientações aos usuários (Figura 3.7). 


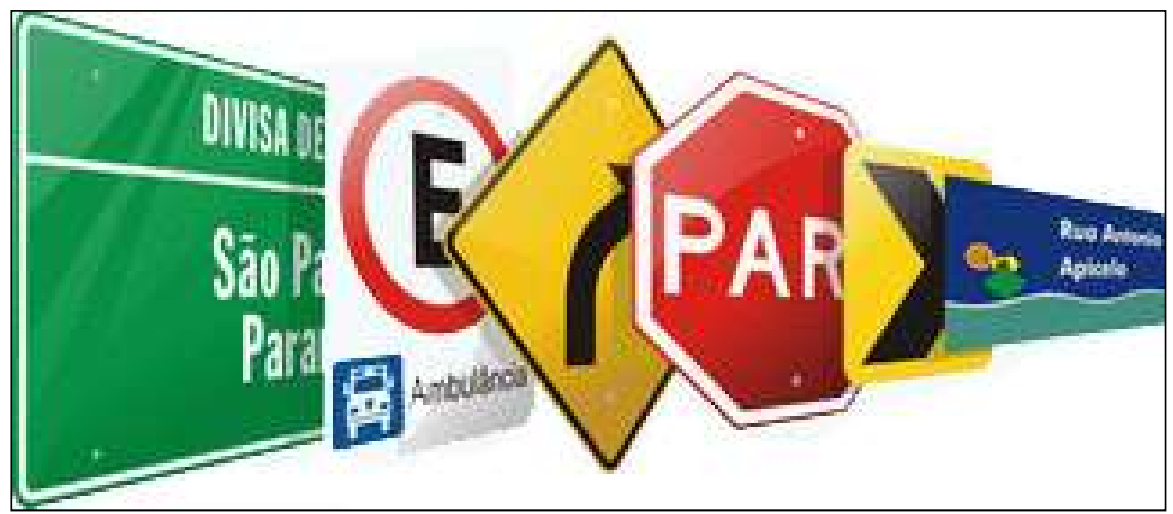

Figura 3.7: Exemplos de sinalização vertical Fonte: RBS (2016)

Características como a forma, o tamanho, a cor, a visibilidade diurna e noturna, a durabilidade ou a resistência à intempérie e o posicionamento na via são os principais requisitos técnicos da sinalização (DNIT: 2010 e CETRA: 2003). É fundamental para que os motoristas e pedestres tenham as informações necessárias para que entendam as diferentes situações que se apresentam na via e possam reagir. O cumprimento dos requisitos técnicos adequados deve garantir uma leitura clara e concisa da mensagem e com tempo de antecipação suficiente, de acordo com as características físicas e operacionais da via (SAMPEDRO: 2010).

O uso incorreto ou a falta de sinalização pode levar os motoristas e pedestres a cometerem erros ou manter comportamentos incompatíveis com o que o ambiente viário pede, ocasionando acidentes de grande severidade. A sinalização vertical pode ser classificada em três grupos, segundo sua função: regulamentação, advertência e indicação (DNIT: 2010). As placas de regulamentação têm por objetivo informar aos usuários da via as limitações, proibições ou restrições que existem em determinado trecho ou via. As placas de advertência visam advertir aos usuários do sistema de tráfego sobre a existência de um perigo e sua natureza. Já as placas de indicação têm a finalidade de identificar as vias e orientar seus usuários, fornecendo-lhes informação útil.

Nodari (2003) menciona os quatro princípios básicos para o uso das placas de sinalização:

- Localizar as placas com antecedência suficiente do ponto de tomada de decisão;

- Prover tempo de resposta;

- Prover informação redundante;

- Evitar áreas em que a atenção do motorista seja muito solicitada. 


\subsubsection{Sinalização horizontal}

A sinalização horizontal é constituída basicamente por marcações na pista, que têm objetivo em complementar as regras de trânsito ou advertir sobre a presença de outros dispositivos de controle de tráfego, como semáforos, e para transmitir as regras e advertências aos usuários da via. O DNIT (2010b) menciona que suas principais características são a cor, visibilidade diurna e noturna, uniformidade, durabilidade e resistência à derrapagem.

A sinalização horizontal pode ser classificada em: marcas transversais (Figura 3.8), longitudinais (Figura 3.9), transversais de canalização (Figura 3.10), de delimitação de estacionamento (Figura 3.11), e as inscrições no pavimento (Figura 3.12).

As marcas longitudinais consistem em linhas contínuas ou tracejadas que ordenam e separam os fluxos de tráfego e regulamentam a ultrapassagem. As marcas transversais ordenam os deslocamentos frontais de veículos e de pedestres induzem a redução de velocidade e indicam posições de parada em interseções e travessia de pedestres. As marcas de canalização são utilizadas para direcionar os fluxos veiculares em situações que provoquem alterações na trajetória natural, como em situações de acesso, interseções ou mudanças de alinhamento da via. As marcas de delimitação são utilizadas com a sinalização vertical para indicar e controlar áreas de estacionamento ou parada de veículos. E, por último, as inscrições no pavimento são usadas em complementação de outros dispositivos de sinalização para orientar e/ou advertir o condutor quanto às operações e condições da via (DNIT: 2010). 


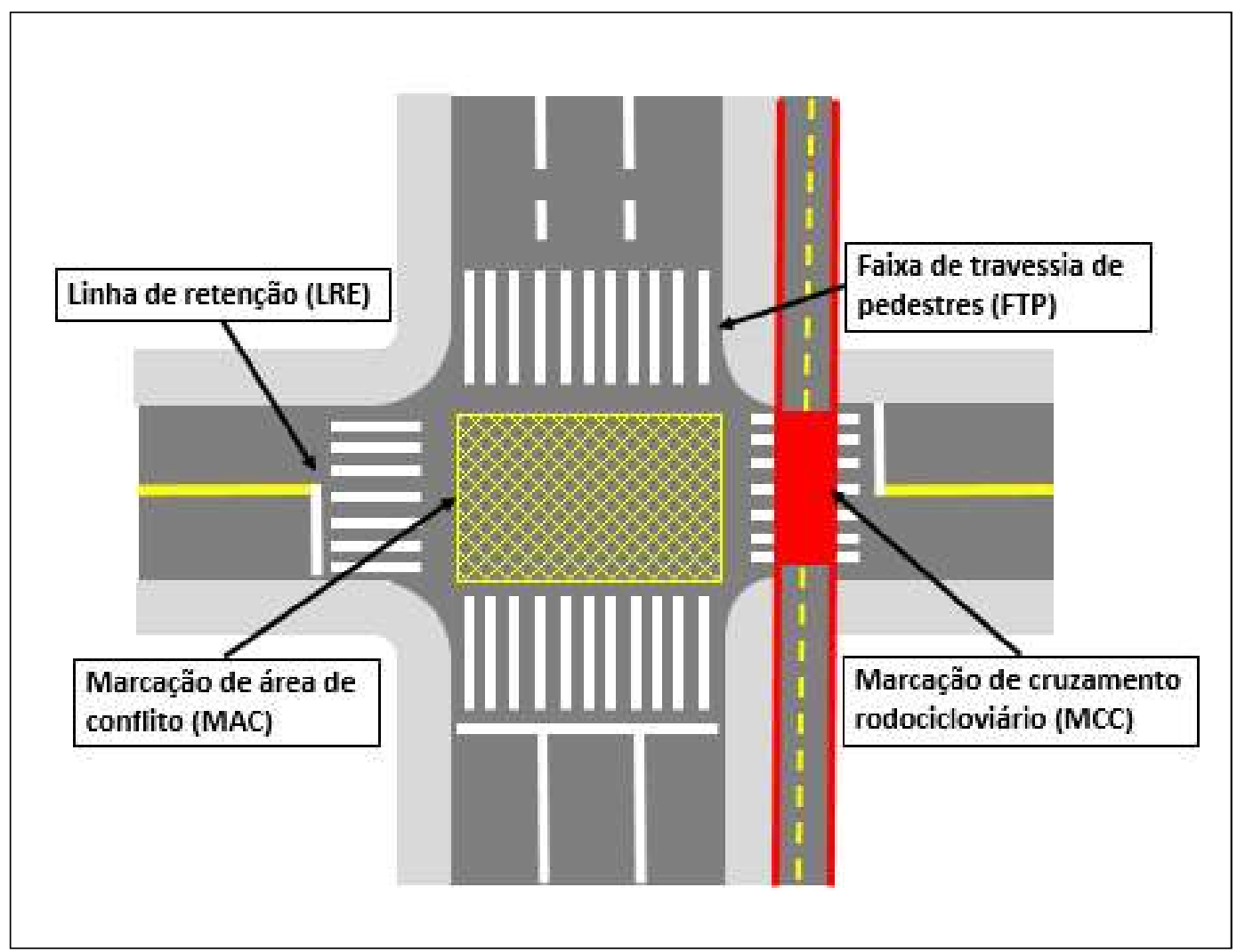

Figura 3.8: Exemplos de marcações transversais.

Fonte: Adaptado de Contran (2007). 


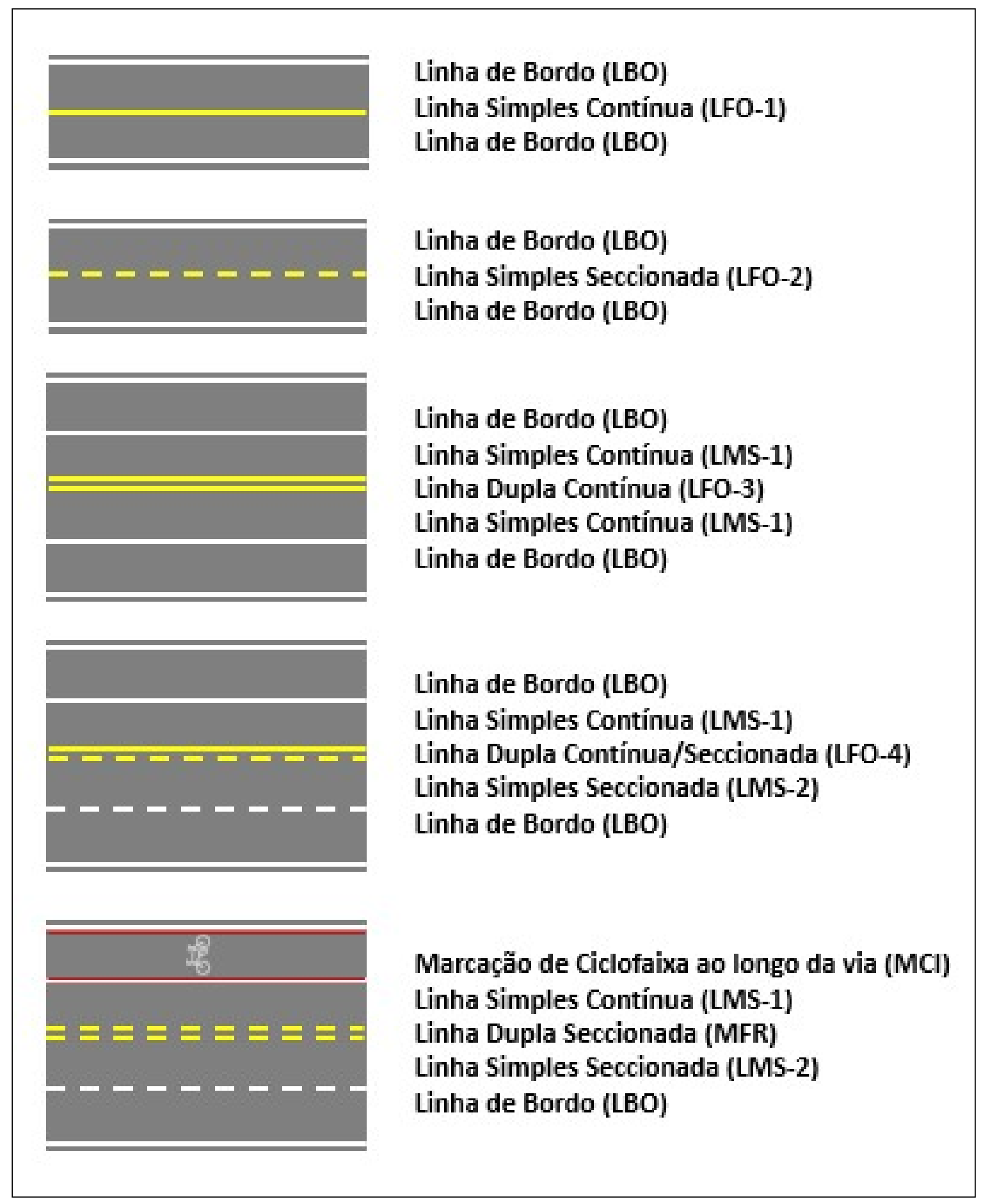

Figura 3.9: Exemplos de marcas longitudinais.

Fonte: Adaptado de Contran (2007). 


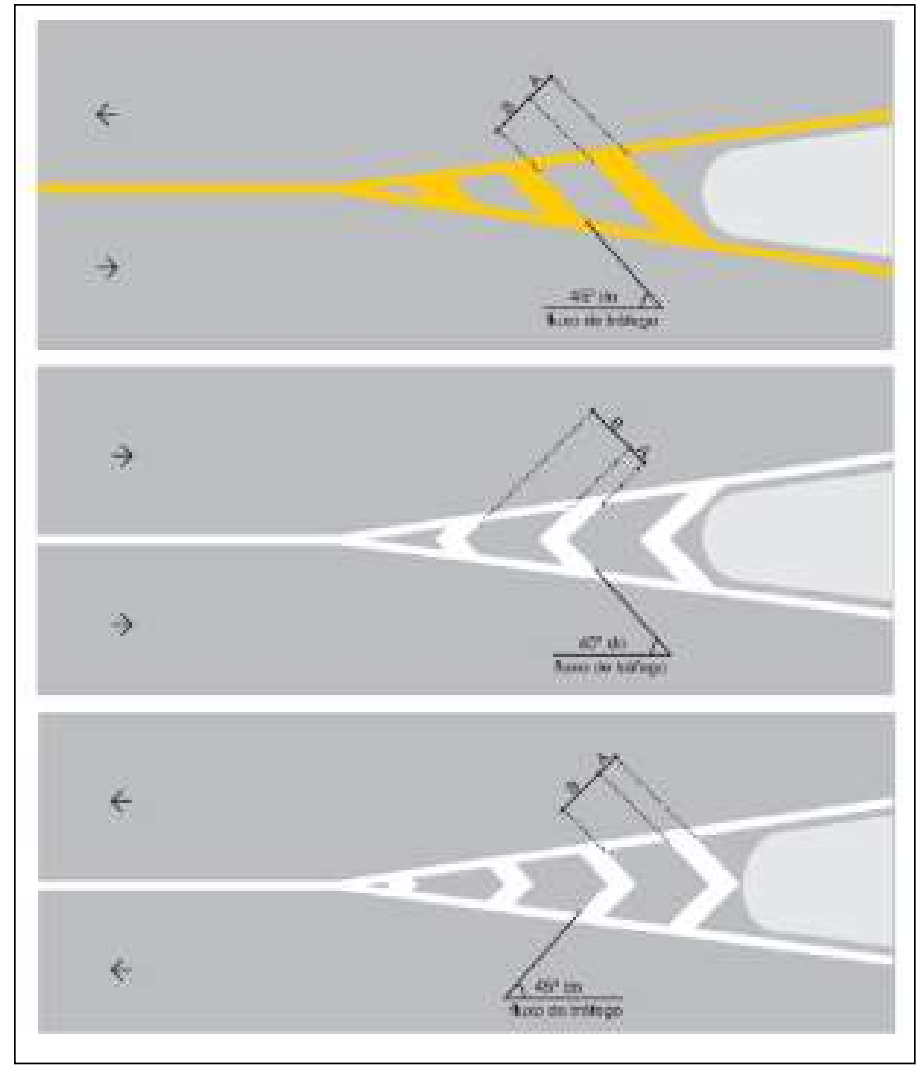

Figura 3.10: Exemplos de marcas de canalização. Fonte: Contran (2007).

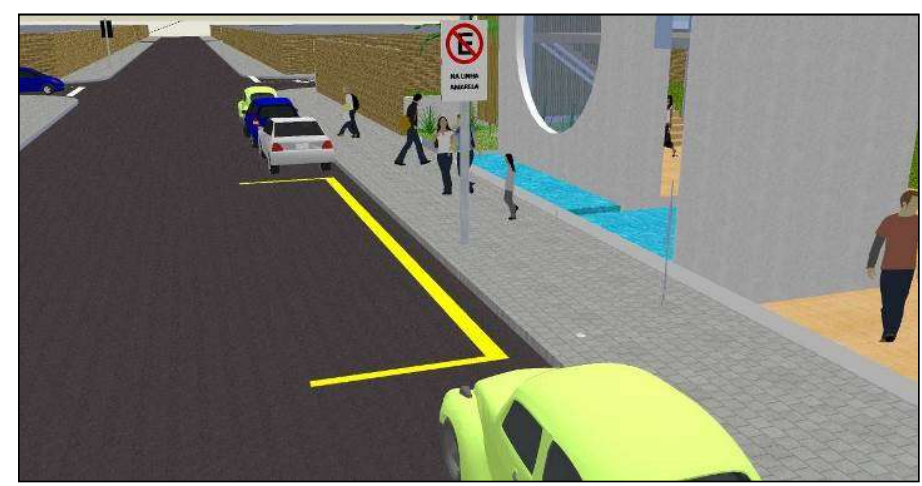

Figura 3.11: Exemplo de marca de delimitação de proibição de estacionamento. Fonte: Trânsito em Foco (2009).

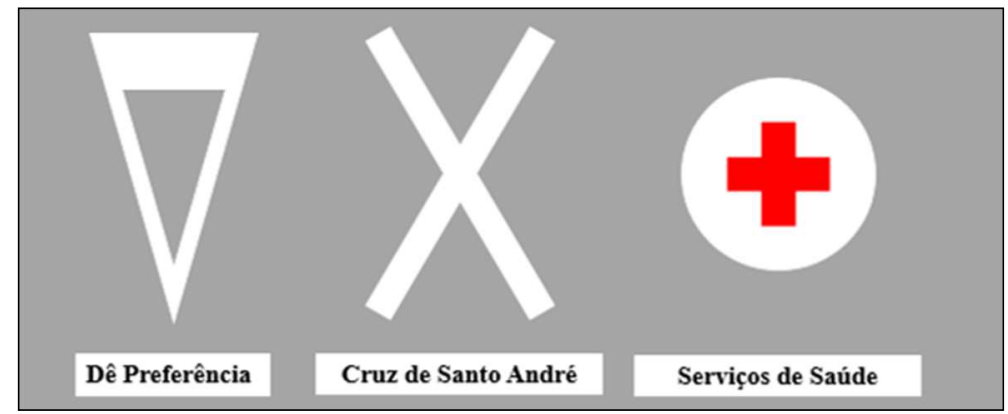

Figura 3.12: Exemplos marcas de inscrições no pavimento. Fonte: Adaptado de Contran (2007). 


\subsubsection{Dispositivos auxiliares}

Os dispositivos auxiliares são elementos aplicados ao pavimento da via, junto a ela ou nos obstáculos próximos, de forma a tornar mais eficiente e segura a operação da via. Com diversas cores, formas, materiais, presença ou não de elementos refletivos, podem ser utilizados para:

- Incrementar a percepção da sinalização, do alinhamento da via ou de obstáculos à circulação;

- Reduzir a velocidade praticada;

- Oferecer proteção aos usuários;

- Alertar os condutores quanto a situações de perigo potencial ou que requeiram maior atenção.

Um dos dispositivos mais conhecidos é o tachão ou Permanent Raised Pavement Marker (PRPM) que consistem em elementos reflexivos fixados na superfície do pavimento e têm como função básica de canalização de tráfego. Visam delimitar as faixas ou pistas e, também são utilizadas para a redução de velocidade, complementando a função das sinalizações horizontais, sobretudo no período da noite. Esses dispositivos produzem o efeito semelhante das luminárias, que consiste em alertar de forma cômoda e efetiva os motoristas, porém com custos de implantação e manutenção bem inferiores, uma vez que não necessita de energia elétrica, como mostrado na Figura 3.13 (CETRA: 2003). Os PRPM também auxiliam o motorista nos períodos noturnos, aumentando a confiança e diminuindo a severidade dos acidentes.

Entre outros dispositivos estão os canalizadores e os delimitadores, quase sempre reflexivos que tem função de marcadores do alinhamento e de balizadores, respectivamente, implantados nas bordas das curvas horizontais ou em locais que apresentam modificações potencialmente perigosas da geometria da seção da transversal, Figura 3.14. Servem para alertar os motoristas e reforçar a percepção adequada do alinhamento da via, principalmente nos períodos noturnos, onde há deficiência em iluminação. 


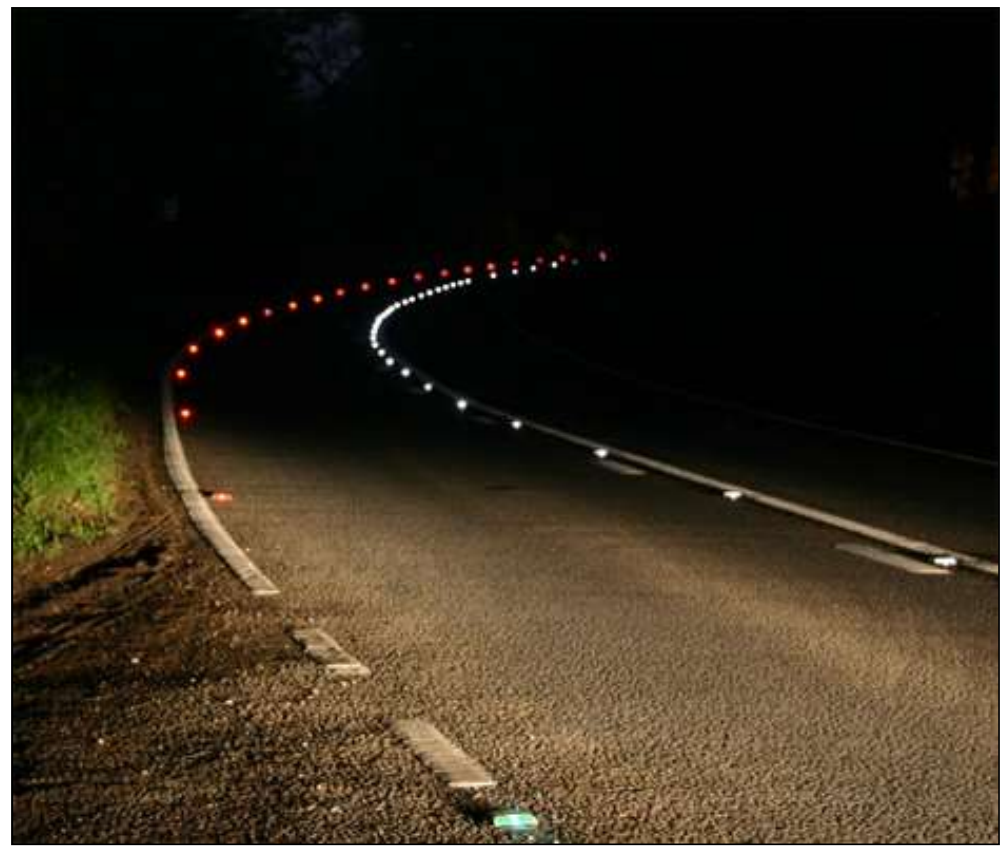

Figura 3.13: Tachões de LED alimentados com energia solar. Fonte: Treehugher (2007).
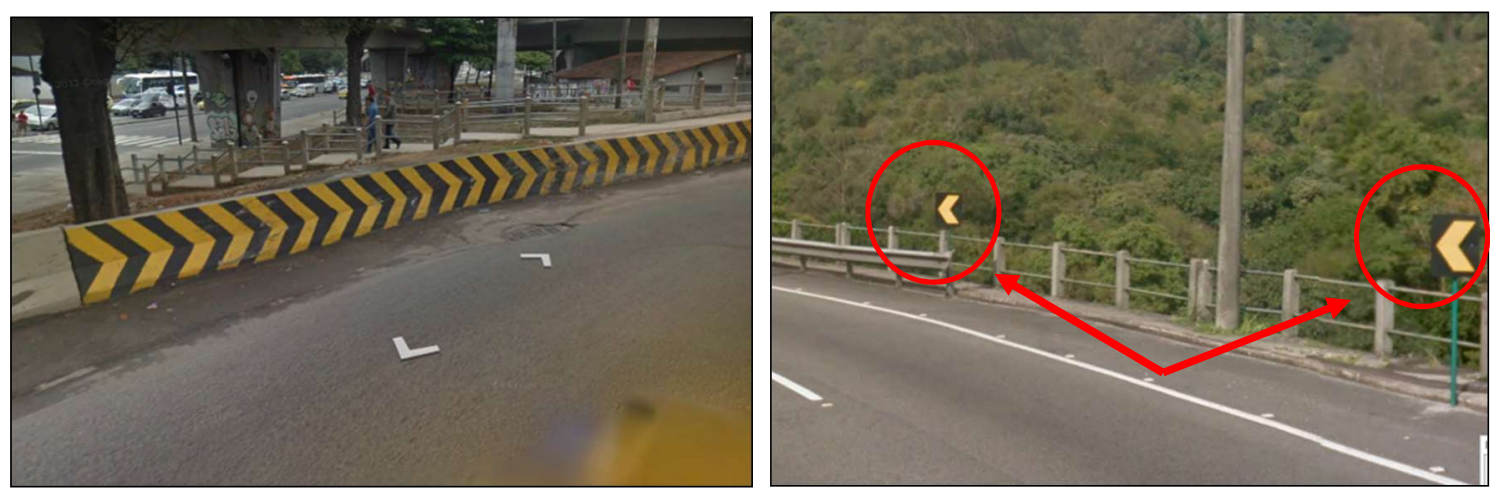

Figura 3.14: Exemplos de canalizadores e delimitadores. Fonte: Google Maps (2015).

Outro exemplo de dispositivo auxiliar é a guia sonora ou rumble strip, Figura 3.15, que consiste em faixas salientes ou entalhes localizados na superfície do pavimento que fornecem uma advertência sonora e sensível ao motorista para que ele reposicione o veículo ou diminua a velocidade. Pode ser utilizada em acostamentos, no eixo da via ou transversalmente a pista. 


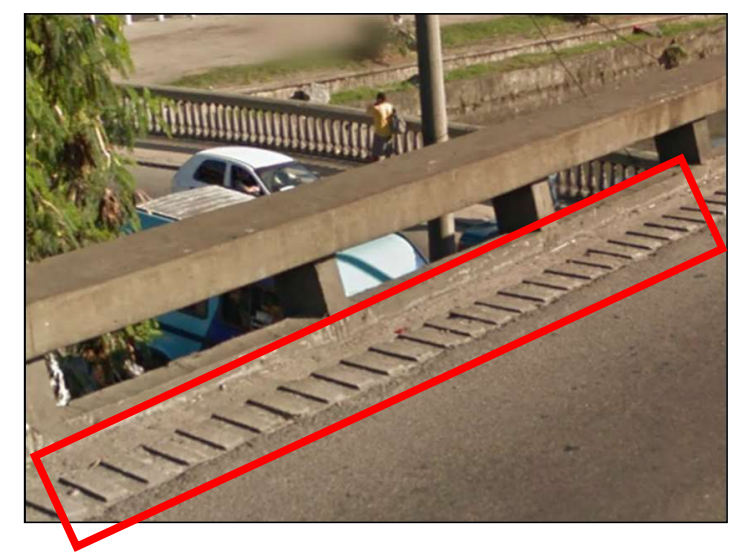

Figura 3.15: Guia sonora ou rumble strips. Fonte: Google Maps (2015).

As guias sonoras de acostamento são utilizadas nos trechos que causem tédio e monotonia aos motoristas, sendo efetivas para os motoristas não saírem das pistas. As guias de pista são utilizadas para moderar as velocidades dos veículos ao se aproximarem de situações de perigo, como por exemplo, curvas fechadas ou interseções e as guias de eixo são implantadas em vias que não apresentam elementos físicos de separação, como barreiras de concreto, e advertem os motoristas que estão invadindo a faixa destinada ao tráfego de carros no sentido oposto. As rumple strips favorecem uma redução notável tanto no número de acidentes quanto na severidade dos acidentes, provocados por condutores distraídos (TEDESCO: 2004).

\subsubsection{Painéis de mensagens variáveis}

Os painéis de mensagens variáveis (PMV) são os dispositivos eletrônicos implantados nas vias para a exibição de mensagens aos motoristas contendo informações sobre as condições de tráfego em tempo real, indicações sobre rotas alternativas, alterações na operação das vias devido a incidentes ou eventos programados, condições climáticas complexas e mensagens educativas (PEREIRA: 2005).

Os benefícios dos PMV dependem do uso de cores previamente codificadas, da clareza e da simplicidade das mensagens buscando o uso de frases curtas e fáceis de ler e do uso de símbolos e palavras padronizadas. Além disso, como no caso dos semáforos, é importante garantir a visibilidade do sinal a qualquer hora e sob quaisquer condições do clima e a fácil percepção dos PMV no meio de outras fontes visuais (ARBAIZA e LUCAS: 2004). 
É reconhecido que a utilização dos PMV incide na redução do número de acidentes. Como exemplo, Kolisetty et al. (2004) reportam uma redução da velocidade média das rodovias de $10 \mathrm{~km} / \mathrm{h}$, o qual resultou numa redução de acidentes fatais e graves em condições adversas, como neblina e chuva.

\subsection{INTERSEÇÕES}

Devido ao grande número de conflitos e de acidentes que ocorrem nas interseções, principalmente nas áreas urbanas, elas são consideradas como pontos de maior periculosidade na rede viária. Os acidentes mais comuns nesses pontos são os abalroamentos transversais e os atropelamentos, tanto de pedestres, como de ciclistas.

Existem múltiplos fatores que influenciam na ocorrência dos acidentes no que tange as interseções: o projeto geométrico, o número de aproximações, o ângulo da interseção, o tipo de controle de tráfego, manobras permitidas, distância de visibilidade etc. (FHWA: 2000a; NCHRP: 2007).

O projeto dos elementos geométricos que constituem uma interseção baseia-se, em geral, nos mesmos princípios que governam o projeto geométrico dos demais componentes da rodovia (DNIT: 2005). Um projeto geométrico fraco ou complexo demais pode provocar confusão nos condutores (Figura 3.16).

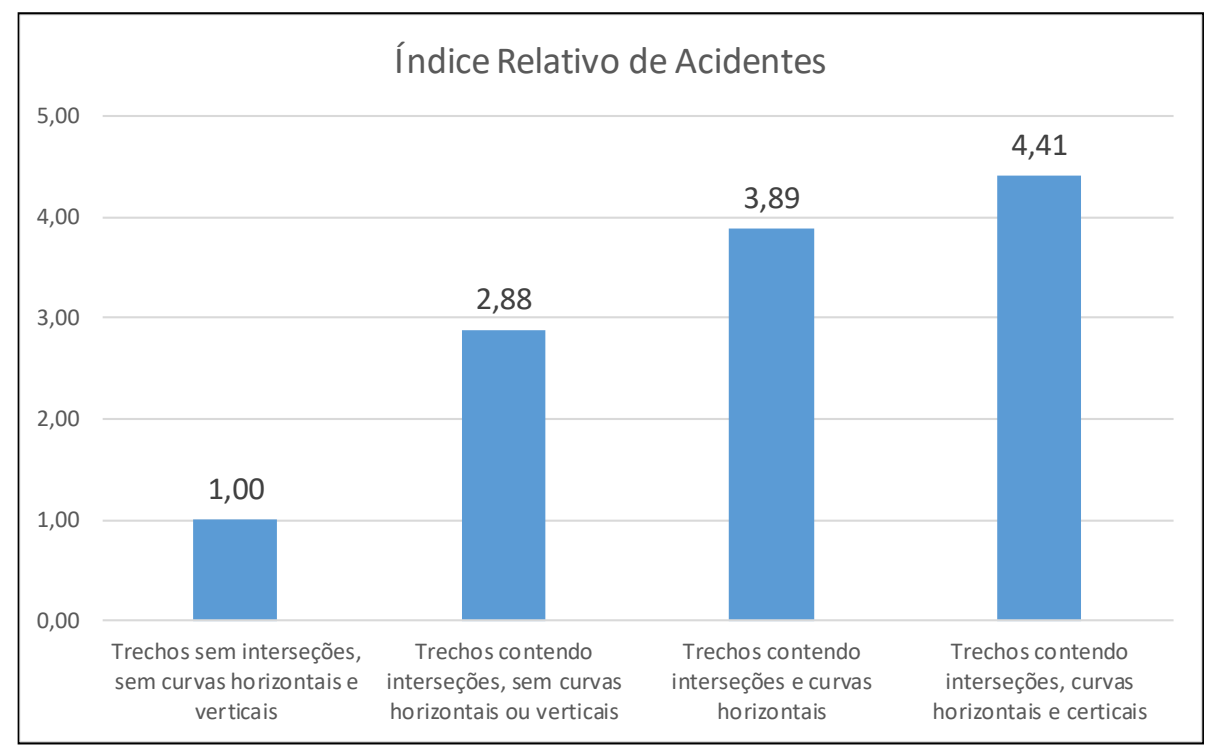

Figura 3.16: Efeito dos alinhamentos das aproximações nos índices de acidentes. Fonte: DNIT (2005). 
Outro aspecto a ser considerado é o número de aproximações. Uma aproximação simples, com três ramos, tem um melhor impacto sobre a segurança de tráfego. A presença de canalizações e faixas auxiliares reduz o número de pontos de conflitos e, por conseguinte, a severidade das manobras conflitantes, fornecendo as informações adequadas aos condutores sobre os movimentos permitidos nas interseções (Figura 3.17). Além disso, as ilhas de canalização fornecem áreas de refúgio para os pedestres.

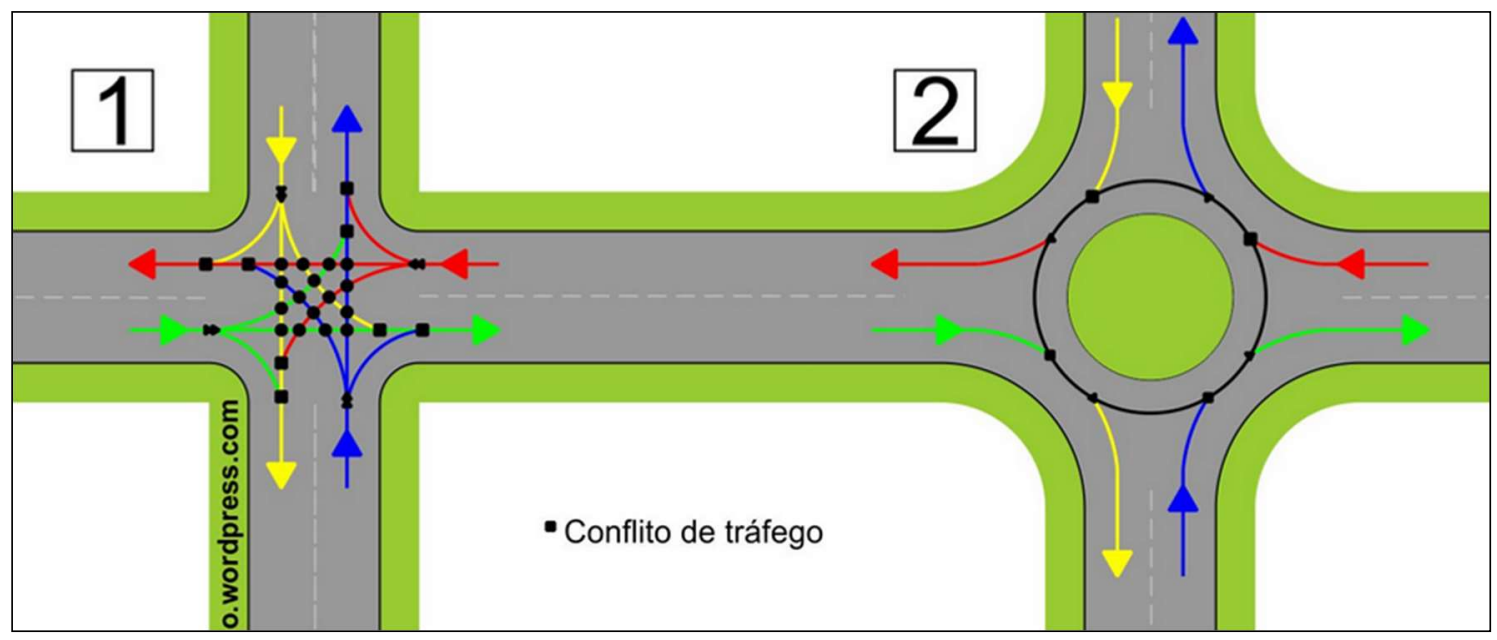

Figura 3.17: Pontos de conflito e possível medida corretiva. Fonte: Trânsito em Foco (2011).

Faixas auxiliares de mudança de velocidade permitem que os veículos que seguem em frente passem os veículos mais lentos que se preparam para efetuar manobras de giro. Vários estudos citados em NCHRP (2007) mostram benefícios de uma implantação correta de faixas auxiliares, com reduções das frequências de acidentes entre 7\% e 70\% em interseções urbanas e, também reduções gradativas com a implantação de ilhas de canalização.

Resultados indicados por FHWA (2000a) mostram benefícios decorrentes da implantação de faixas para a realização das manobras de giro em interseções. A Tabela 3.2 mostra o impacto na implantação de faixas auxiliares na redução de acidentes em interseções de quatro ramos com giros à esquerda e à direita.

Tabela 3.2: Impacto nos acidentes das faixas para os giros em interseções

\begin{tabular}{c|cccc}
\hline \multirow{2}{*}{ Controle de tráfego } & \multicolumn{3}{|c}{ Redução de acidentes por implantação de faixas para (\%) } \\
\cline { 2 - 5 } & \multicolumn{3}{|c}{ Giros à esquerda } & \multicolumn{2}{c}{ Giros à direita } \\
& Um acesso & Ambos os acessos & Um acesso & Ambos os acessos \\
Não semaforizadas & 24 & 42 & 5 & 10 \\
Semaforizadas & 18 & 33 & 2,5 & 5 \\
\hline
\end{tabular}
Fonte: Adaptado de FHWA (2000a). 
Raios e ângulos de entradas e saídas de interseções devem garantir que os movimentos de giro sejam realizados com facilidade por todos os tipos de veículos passando pela interseção. Seja qual for o tipo de cruzamento, é desejável que as vias concorrentes se encontrem num ângulo igual ou próximo a $90^{\circ}$. Ao realizar manobras em interseções com ângulos obtusos, automóveis de comprimento grande têm pontos cegos na hora de realizar as manobras. Em um ângulo agudo, os automóveis demandam tempo excessivo para a realização da manobra e, com isso, ficam à mercê da corrente do tráfego que cruza, aumentando os riscos dos acidentes (DNIT: 2005).

Outra questão a ser avaliada no que se refere às interseções é a visibilidade livre que o motorista deve ter para que possa identificar os possíveis perigos de conflitos e ter tempo para proceder às manobras necessárias. Essa visibilidade depende da velocidade dos veículos envolvidos e do tempo de percepção, reação e frenagem do motorista (DNIT: 2005). A visibilidade pode ser afetada por inúmeros fatores como: ângulo de interseção, alinhamentos vertical e horizontal, velocidade nas vias, vegetação e topografia do local e presença de obstáculos e de edificações (Figura 3.18).

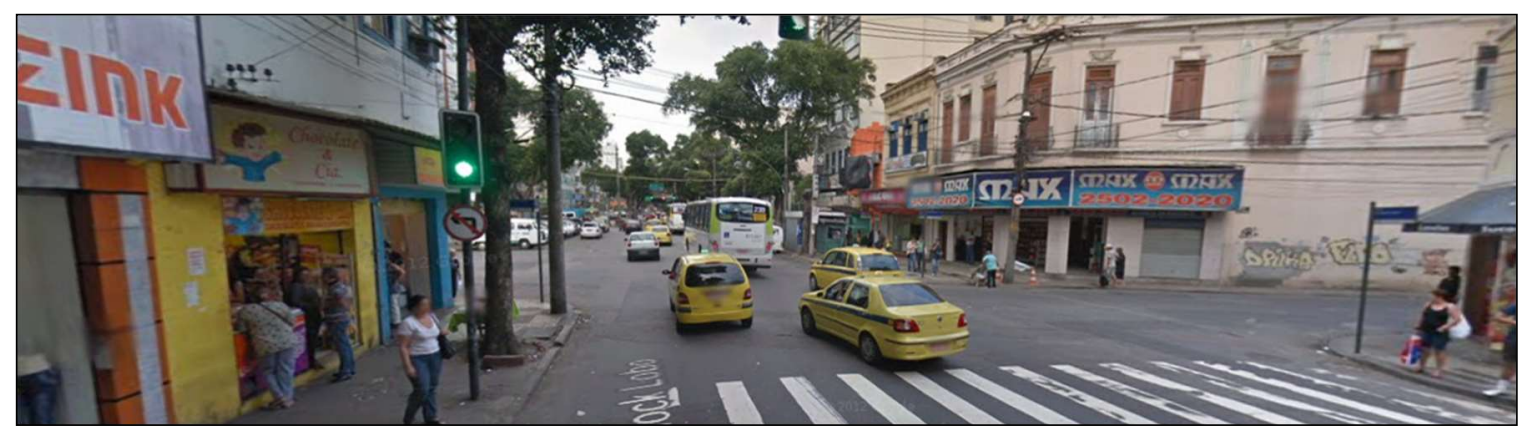

Figura 3.18: Interseção com visibilidade muito reduzida. Fonte: Google Maps (2015).

Pode-se controlar o tráfego nas interseções com o uso de placas de prioridade ou utilização de semáforos, dependendo do fluxo de tráfego e das condições operacionais, oferecendo, assim, um maior nível de segurança. 


\subsection{ACESSOS E SAÍDAS}

São considerados acessos todos os pontos da via por onde os veículos entram, podendo-se mencionar as interseções, aberturas no canteiro central, entradas e saídas públicas e residenciais e as rampas de entrada e saída nas expressas.

O NCHRP (2007) mostra que existe uma estreita relação entre as taxas de acidentes e os diferentes níveis de controle de acesso. Como exemplo de tal fato tem-se que vias com acessos controlados apresentam entre $50 \%$ e $65 \%$ menos acidentes do que aqueles sem controle de acesso.

A eliminação da variedade e do espaçamento dos acessos constitui uma das medidas de influência na diminuição efetiva do número de acidentes de trânsito (TXDOT: 2004). A combinação com o uso adequado do canteiro central é particularmente efetivo no aumento da segurança do tráfego. A causa está no fato de se conseguir uma diminuição significativa de eventos inesperados e separação de pontos de decisão. A Tabela 3.3 apresenta o efeito do nível do controle de acessos na segurança de vias urbanas, considerando o tipo de canteiro central utilizado.

Tabela 3.3: Taxas de acidentes em vias urbanas em função do nível de controle de acessos (acidentes por milhão de veículos.km)

\begin{tabular}{c|ccc}
\hline \multirow{2}{*}{ Acessos por $\mathbf{k m}$} & \multicolumn{3}{|c}{ Tipo de canteiro central } \\
\cline { 2 - 4 } & Sem canteiro & $\begin{array}{c}\text { Com faixas para } \\
\text { giros à esquerda }\end{array}$ & $\begin{array}{c}\text { Com proibição de } \\
\text { atravessar }\end{array}$ \\
$\mathbf{3 3 2}$ & 6,1 & 5,4 & 4,6 \\
$\mathbf{3 2 - 6 4}$ & 11,7 & 9,4 & 8,2 \\
$\mathbf{6 4 - 9 6}$ & 15,0 & 12,6 & 10,9 \\
$>\mathbf{9 6}$ & 17,0 & 14,7 & 13,1 \\
Média & 14,4 & 11,0 & 9,0 \\
\hline
\end{tabular}

Fonte: Adaptado de Txdot (2004).

Outros estudos que abordam a relação entre a densidade de acessos na via e a segurança de tráfego constatam um acréscimo no número de acidentes à medida que aumenta a densidade de acessos (GAO: 2003; TXDOT: 2004; EWING e DUMBAUGH: 2009).

A proximidade dos acessos às interseções das vias é um fator que também pode influenciar, pesquisas sugerem que quanto mais longe as interseções estiverem localizadas, o número de conflitos diminui, proporcionando mais tempo e espaço para os veículos entrarem na via 
(NCHRP: 2007). Também acrescentam risco ao acesso a frequente entrada e saída de veículos pesados e lentos.

\subsection{ENTORNO}

Esse item se refere a todas as condições que se constituem como fonte de risco notável, em particular em caso de perda de controle e saída do veículo da pista, como a presença de postes, placas, árvores, pilares de pontes, obras de drenagem e outros obstáculos nas laterais da via (CETRA: 2003). Além disso, as condições das áreas adjacentes à via, sua largura e a distância da pista de rolamento influenciam tanto na quantidade quanto à gravidade dos acidentes (TRB: 1987). São referenciados estudos que calculam que entre $25 \%$ e $30 \%$ do total de acidentes de trânsito ocorram devido a choques contra obstáculos colocados nas proximidades da pista.

Acredita-se que sejam inevitáveis a saída de alguns veículos da pista de rolamento e a seguinte invasão das áreas adjacentes à via (NODARI: 2003). Assim sendo, o TRB (1987) destaca a importância de se oferecer uma maior segurança aos possíveis veículos desgovernados por meio de ações que visam um acondicionamento das áreas adjacentes e ao gerenciamento dos obstáculos perigosos.

É estudada a implantação de uma zona livre de obstáculos fixos com uma inclinação suave, no intuito de facilitar a retomada do controle do veículo e o regresso à pista em segurança. A utilização da largura adequada nesta zona depende das particularidades de cada local e a sua determinação é condicionada a fatores como inclinação do talude, velocidade da via e outros fatores (TRB: 2001). Na Tabela 3.4 são apresentadas as reduções do número de acidentes em consequência ao aumento da largura da zona livre de obstáculos.

Existem casos onde não é possível remover elementos perigosos para áreas mais afastadas. Nesses casos é utilizada a implantação de dispositivos auxiliares ou medidas que eliminem ou reduzam a severidade dos acidentes em caso de choques, como, por exemplo, barreiras e atenuadores de impacto, como vegetação, melhorias no meio-fio e bases deformáveis ou deslizantes em placas e postes (Figura 3.19). 
Tabela 3.4: Relação entre largura livre de obstáculos e o número de acidentes.

\begin{tabular}{c|cc}
\hline Aumento da largura da & \multicolumn{2}{|c}{ Redução do número de acidentes (\%) } \\
\cline { 2 - 3 } zona livre de obstáculos & Em retas & Em curvas \\
$\mathbf{( m )}$ & 13 & 9 \\
$\mathbf{1 , 5}$ & 21 & 14 \\
$\mathbf{2 , 4}$ & 25 & 17 \\
$\mathbf{3 , 0}$ & 29 & 19 \\
$\mathbf{3 , 6}$ & 35 & 23 \\
$\mathbf{5 , 0}$ & 44 & 29 \\
$\mathbf{5 , 6}$ &
\end{tabular}

Fonte: Adaptado de Ogden (1996).

Para Sampedro (2006), o gerenciamento adequado dos obstáculos fixos é quase a única opção nos ambientes urbanos, onde a limitação de espaço impede qualquer tratamento das áreas adjacentes à via.
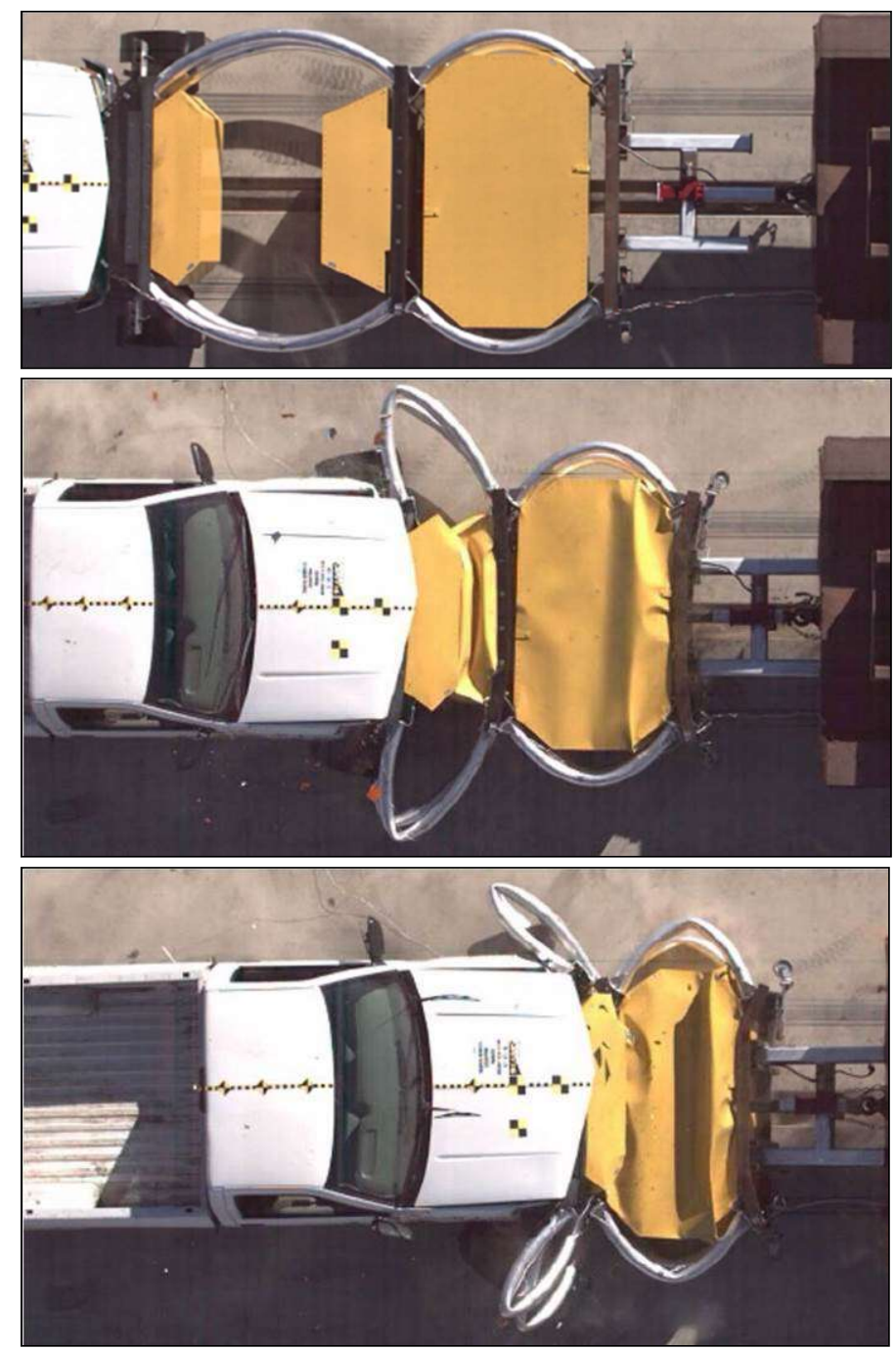

Figura 3.19: Exemplos da ação de atenuadores de impacto. Fonte: TrafFix Devices (2016). 
Quando as áreas adjacentes não estão adequadamente protegidas ou delimitadas, devido à ausência ou às más condições das cercas nas laterais da via, ou de outros elementos de proteção, é frequente a invasão de animais de grande porte, sobretudo em rodovias (CETRA: 2003). A presença desses animais é um elemento de potencial perigo porque constituem eventos quase sempre inesperados para os motoristas. No período noturno, a impossibilidade de adverti-los com suficiente antecipação faz com que o risco seja ainda maior. Os choques contra os animais e a perda do controle do veículo são os principais tipos de acidentes provocados.

\subsection{DRENAGEM}

Os dispositivos de drenagem adequados são essenciais para o funcionamento da via, tanto do ponto de vista estrutural como do operacional. $\mathrm{O}$ acúmulo excessivo de água nas vias pode gerar transtornos, podendo interromper por completo a circulação de veículos.

Com respeito ao ponto de vista estrutural, o aspecto da drenagem está relacionado ao que se refere à capacidade de infiltração da água na camada de rolamento. Em situações em que esta camada apresenta índices altos de permeabilidade, a água infiltra para as camadas inferiores, carregando partículas e enfraquecendo a estrutura do pavimento. Esta situação pode resultar tanto no colapso da estrutura do pavimento, como na formação de trincas e buracos, ocasionando os acidentes citados no item 3.3. Ao relacionar com as questões de superfície do pavimento, o excesso de água, gera a formação de poças ou espelhos d'água, provocando o efeito de aquaplanagem, fenômeno que ocorre quando os pneus perdem o contato com o pavimento, perdendo a aderência necessária a segurança. Ao reduzir o atrito, o condutor pode perder o controle da direção e prejudicar a frenagem do veículo também (BERNUCCI et al.: 2007).

Outros fatores também devem ser postos em discussão, como a diminuição da visibilidade, como mostrada em Figura 3.20, e a execução e manobras bruscas para evitar as poças, podendo haver a invasão da faixa de tráfego em sentido contrário. Ainda pode-se mencionar o acúmulo de terra e lama sobre a pista, o que causa uma redução de resistência à derrapagem. 

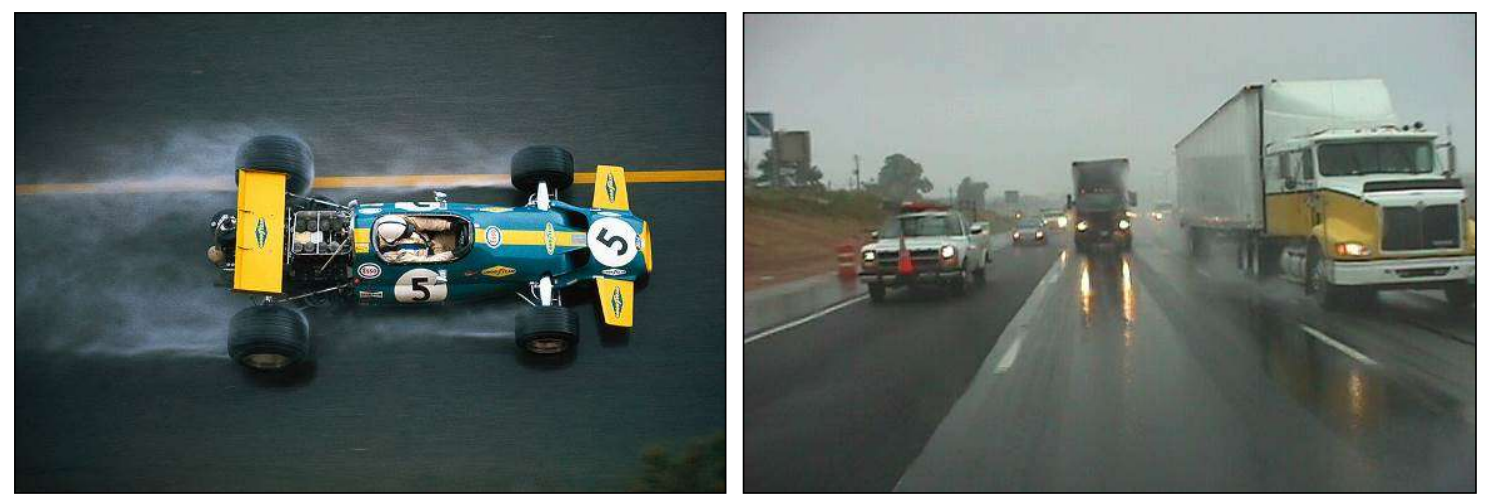

Figura 3.20: Efeito do spray em diferentes pavimentos.

Fonte: Schelb (2012) e Carlson e Stout (2003).

\subsection{ILUMiNAÇÃo}

O período noturno é caracterizado pelo aumento considerável da severidade dos acidentes, sobretudo em locais e vias onde a iluminação é escassa. Segundo Peña (2004), 9\% do total de acidentes que ocorreram na Espanha, em 2002, aconteceram à noite. No entanto, ao analisar só os acidentes com vítimas, a porcentagem aumenta para $35 \%$ e os acidentes com mortes se eleva para 46\%. O aumento do grau de severidade dos acidentes de acordo com o período do dia é mostrado na Figura 3.21.

Na Figura 3.21, a linha verde representa o volume de tráfego e a azul, o número de acidentes com vítimas durante as 24 horas do dia. A linha vermelha representa o Índice de severidade, mostrando que os maiores valores ocorrem entre meia noite e $06 \mathrm{~h} 00$, o que pode estar associado a fatores fisiológicos do ser humano, como cansaço, sono.

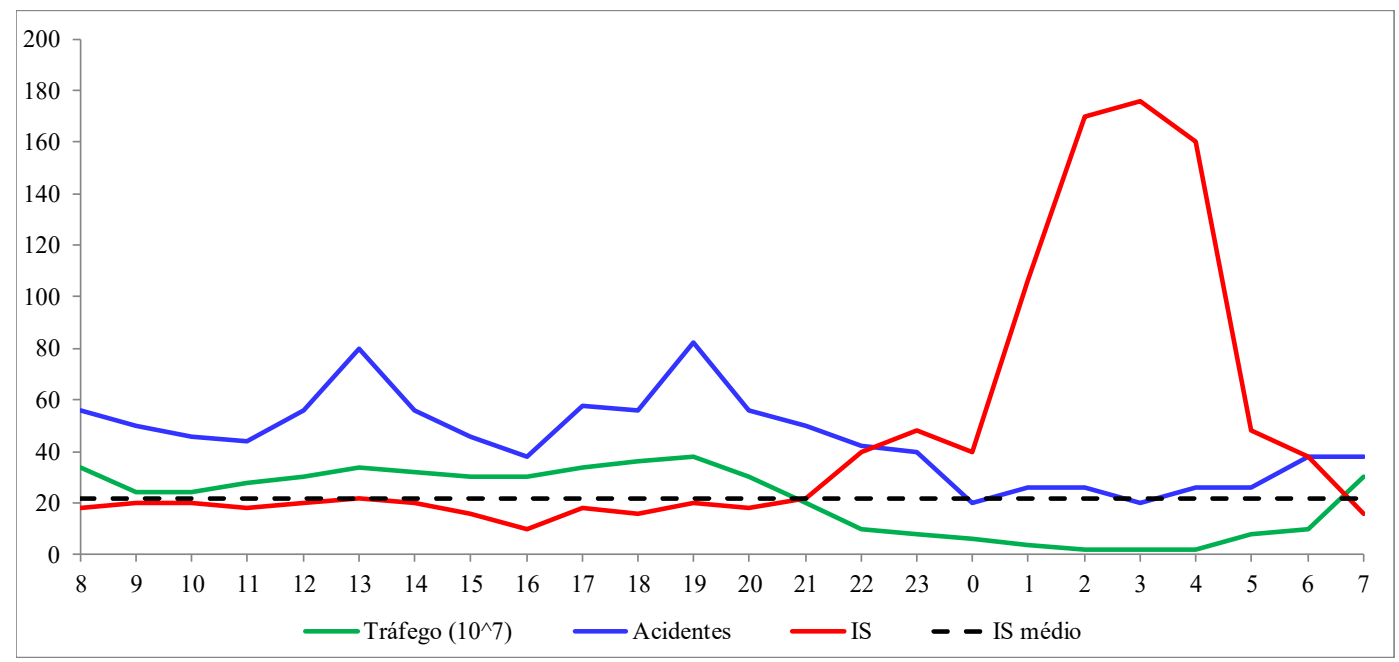

Figura 3.21: Acidentalidade horária em vias de Valência, Espanha. Ano de 2000. Fonte: Peña (2004). 
A falta de iluminação ou suas condições inapropriadas são mais notáveis em ambientes urbanos. Em vias ou locais onde carecem de postes de iluminação, a visibilidade e a capacidade dos motoristas de identificação com precisão dos objetos deixam os pedestres particularmente vulneráveis.

A iluminação incide numa redução dos acidentes e de sua severidade no período noturno. Nas vias com condições adequadas de iluminação, as estatísticas registram uma redução de $30 \%$ a $40 \%$ no número de acidentes, enquanto nas vias sem iluminação a gravidade dos mesmos é seis vezes maior que em vias perfeitamente iluminadas, segundo assinala Norma (2004). Especificamente, a iluminação de vias arteriais urbanas provoca reduções entre $10 \%$ e 44\% dos acidentes nas mesmas (BAKER: 1975). Para o caso das interseções, Nodari

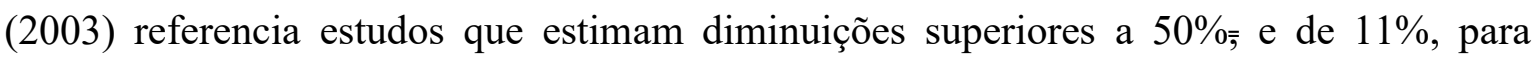
interseções de três e de quatro acessos, respectivamente.

\subsection{TRAVESSIAS PARA PEDESTRES}

Existe uma grande preocupação por parte dos técnicos e projetistas com os pedestres, não apenas por serem os elementos mais frágeis que se deslocam nas vias rurais ou urbanas, mas também por apresentarem deslocamentos irregulares de trajeto e mudanças bruscas de direção e velocidade (DNIT: 2010).

O pedestre urbano, por estar em maior quantidade nas cidades, tem uma maior influência no projeto de vias do que o pedestre na zona rural. Em razão do grande movimento dos veículos nas áreas urbanas, é extremamente custoso tomar medidas adequadas para o atendimento dos pedestres. Contudo, são medidas indispensáveis para o convívio dos pedestres e veículos, principalmente nas áreas centrais de comércio da cidade.

As travessias de pedestres representam os locais onde ocorrem os principais obstáculos de pedestres e veículos e maiores riscos de acidentes decorrentes da interação de forma mais direta entre eles. Podem existir travessias em nível não semaforizadas, em nível com semáforos e em desnível, sendo estas superiores ou inferiores à via, como na Figura 3.22. As travessias em desnível apresentam-se, sob o ponto de vista da segurança, mais efetivas dentre as outras, uma vez que segregam completamente o fluxo de veículos e de pedestres. 
No entanto, os custos de implantação são relativamente altos e nem sempre são utilizadas ou, quando utilizadas, muitas vezes são feitos de forma incorreta.
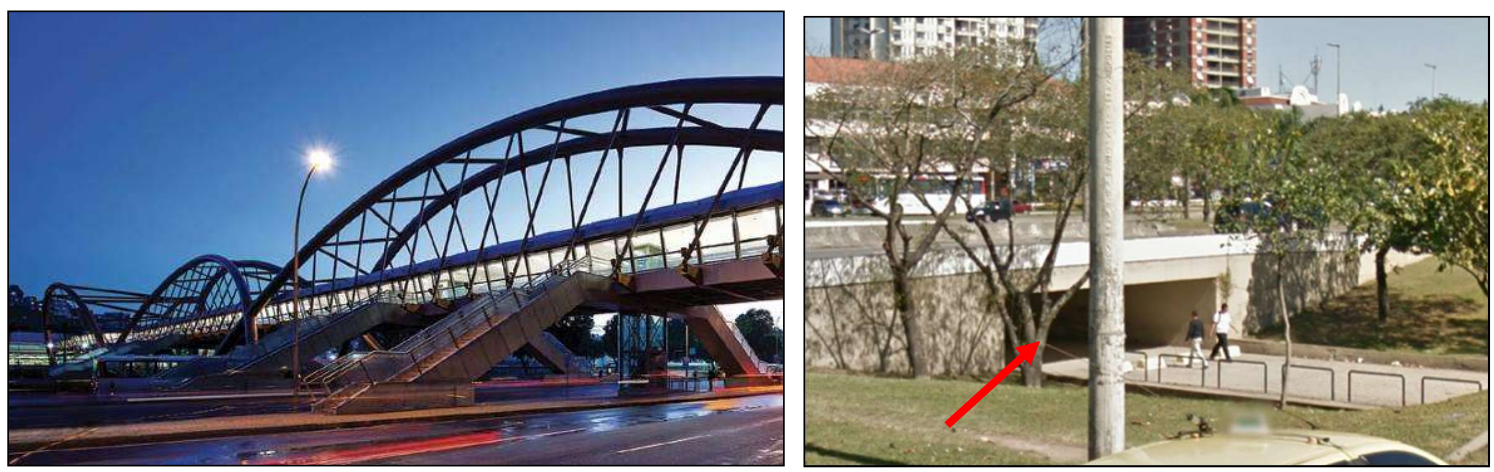

Figura 3.22: Exemplos de travessias de pedestres superiores e inferiores, respectivamente. Fonte: Arcoweb (2011) e Google Maps (2015).

Em vias com travessias semaforizadas, ou seja, aquelas que apresentam fluxos de pedestres e veículos alternados por um semáforo, os principais problemas apresentados são aqueles em que o consumo de tempo imposto ao pedestre é insuficiente para completar a travessia do usuário. Do ponto de vista da percepção dos usuários, um estudo realizado no âmbito brasileiro identificou elementos como presença e distância da travessia ao ponto de ônibus, permissão de estacionamento, largura da via, número de sentidos do trânsito e volume de pedestres (DIÓGENES: 2008).

\subsection{DisPositivos de CONTROLE DE TRÁFEGo}

Faz-se necessária a utilização de Dispositivos de Controle de Tráfego (DCT) para ordenar e assegurar a circulação de veículos e pedestres. Para isso Pereira (2005) classifica diferentes tipos de DCT para:

- Coleta de dados ou detectores de tráfego;

- Armazenamento e processamento dos dados;

- Informações aos usuários;

- Controle e fiscalização do tráfego propriamente dito.

Os dois últimos grupos são os mais destacados e lembrados no ponto de vista da segurança viária. Entre os dispositivos de controle e fiscalização do tráfego se destacam os semáforos 
e os radares de fiscalização eletrônica, enquanto os painéis de mensagens variáveis (PMV), já comentados no item 3.4.1.4, se sobressaem entre os de informações aos usuários.

\subsubsection{Semáforos}

Semáforos são equipamentos eletrônicos usados, principalmente, em interseções para alternar o direito de passagem de veículos e pedestres. Podem ser classificados, de acordo com a sua função, em: semáforos para veículos, para pedestres, semáforos especiais e de aproximação de passagens de nível e de cancelas; e são muito importantes para garantir a organização, fluidez, economia e segurança à circulação (DNER: 1971; KHISTY e LALL: 1998). Sua principal vantagem é conseguir separar os movimentos conflitantes nas interseções, reduzindo, assim, o risco de ocorrência de certos tipos de acidentes, desde que sua instalação seja tecnicamente justificada.

Segundo o DNER (1971) e GAO (2003), os fatores que têm maior influência na segurança viária, no que diz respeito aos semáforos, são a visibilidade dos semáforos, o tempo dos ciclos e a sincronização operacional no caso de semáforos em série. A visibilidade do semáforo tem de ser adequada aos usuários da via para que percebam com antecipação suficiente e reajam em correspondência com a indicação emitida e está relacionado ao número e à localização dos equipamentos, seu tamanho, sua cor, e à proteção contra a luz do sol.

Ao se programar o tempo de ciclo e a sincronização de forma incorreta nos semáforos, além de afetar a fluidez no trânsito, faz com que os motoristas adotem comportamento de risco ou até mesmo ignorem a indicação estabelecida, buscando conforto e economia do tempo em razão da sua segurança e a dos outros usuários.

\subsubsection{Fiscalização eletrônica de velocidade}

Os dispositivos de fiscalização eletrônica de velocidade aliam tecnologias de detecção de veículos e meios de comunicação para identificar os motoristas que infringem limites de velocidade (PEREIRA: 2005). São usados para o controle automático de velocidade, principalmente, as lombadas ou as barreiras eletrônicas, os radares fixos e móveis e, em áreas urbanas, o dispositivo que controla de maneira simultânea a velocidade com que o veículo ingressa na interseção e o avanço do sinal vermelho. 
O uso de radares e de lombadas eletrônicas tem demonstrado efeito positivo no aumento da segurança de motoristas e pedestres por meio do controle e da redução da velocidade na circulação dos veículos. Através de observações realizadas por Framarim et al. (2003), verificou-se uma redução de $23 \%$ nos acidentes em vias da cidade de Porto Alegre, enquanto relata diminuições entre $20 \%$ e $30 \%$ em vias da Inglaterra e do Canadá depois da implantação destes controladores de velocidade.

\subsection{Publicidade}

A publicidade nas vias e rodovias é exibida por painéis nos veículos e por painéis de divulgação de produtos e serviços, tanto no interior das lojas, quanto fora dos pontos de venda. Os elementos mais utilizados nos ambientes urbanos são de propaganda e informação são os outdoors, os busdoors (elementos de marketing localizados nos vidros traseiros dos ônibus), os painéis, os eletrônicos de mensagens variáveis e os luminosos. Alguns exemplos são mostrados na Figura 3.23.
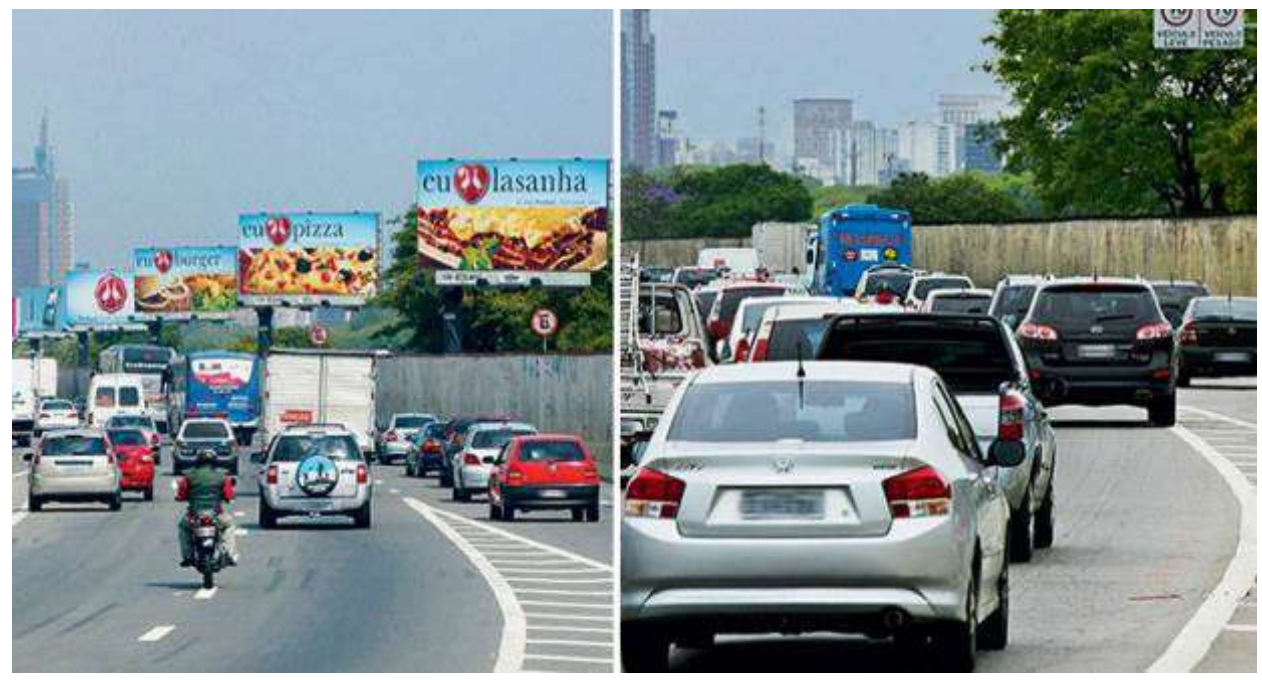

Figura 3.23: Local com excesso de elementos publicitários antes e depois da Lei Cidade Limpa. Fonte: Veja-SP (2013).

O aspecto da publicidade relacionado com a segurança é questão da qualidade do ambiente visual e a proteção do investimento viário. A ocorrência dos elementos de publicidade parece estar associada à distração dos motoristas e dos pedestres. 
Num ambiente onde há o excesso de elementos publicitários, há o conflito entre a atenção do motorista na via e a distração com a publicidade. Acredita-se que a publicidade até estimule o condutor sob condições que não solicitam um grande desempenho do motorista, como por exemplo, uniformidade do pavimento e da geometria, baixo volume de veículos e pouco número de interseções. No entanto, em condições mais complexas, o condutor perde o foco na direção e se distrai. Sobretudo em zonas de centros comerciais, onde a utilização de letreiros luminosos é frequente, pode ocorrer, em período noturno, o comprometimento ou a restrição da capacidade de leitura do motorista de alguns dispositivos de controle de tráfego, como semáforos e os painéis de mensagens variáveis.

\subsection{ESTACIONAMENTO}

As questões relacionadas entre o estacionamento e a segurança viária são bem complexas para serem resolvidas pelas entidades gerenciadoras de transporte nos centros urbanos (BAKER: 1975). As características do estacionamento ou a falta de capacidade para estacionar afetam não somente as questões operacionais do trânsito como também as de segurança.

De acordo com Sampedro (2006), o estacionamento na via pública afeta a segurança da circulação principalmente sob três pontos de vista: nas manobras de entrada e saída dos veículos estacionados, na visibilidade e na circulação dos pedestres.

As manobras de entrada e saída das áreas de estacionamento acrescentam constantemente riscos de colisões com os veículos que se movimentam pela via, o que é mais importante nas vias com maiores volumes de tráfego. A redução da visibilidade é considerável nos casos em que os veículos estacionam nas proximidades das interseções, violando a distância livre requerida para assegurar, tanto a visibilidade, quanto as manobras de conversão dos veículos. Ainda, com muita frequência, a falta de espaço faz com que os veículos estacionem sobre a calçada, atrapalhando ou até interrompendo a circulação fluida e segura dos pedestres (Figura 3.24). Nestes casos, os pedestres são obrigados a se movimentar sobre a pista, aumentando o risco de ocorrência de atropelamentos. 

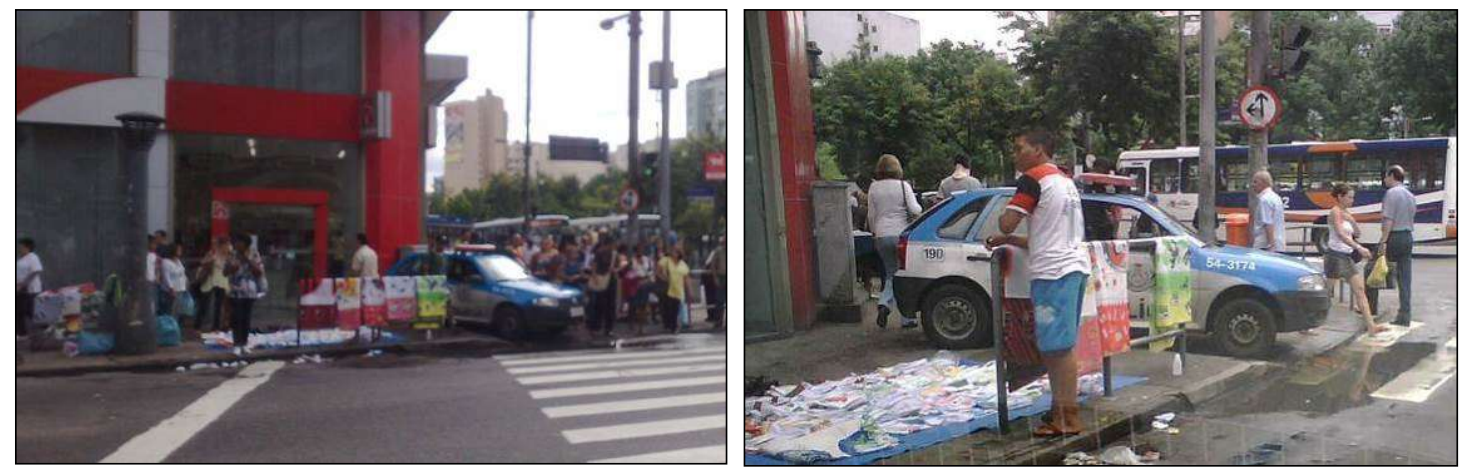

Figura 3.24: Exemplo de estacionamento inapropriado de veículo.

Fonte: $O$ Globo (2009).

\subsection{Congestionamento}

Acredita-se que a redução dos congestionamentos influencie positivamente a segurança, diminuindo o número de acidentes de trânsito (FHWA: 2003). Isso se deve ao fato de que o congestionamento implica numa maior densidade de veículos, e, por conseguinte, uma maior probabilidade de conflito de veículos. No entanto, a velocidade de circulação de um automóvel nessa condição é muito baixa, reduzindo a severidade dos acidentes.

A ocorrência de acidentes em congestionamentos está ligada a acidentes secundários, ou seja, aqueles em que são causados por um anterior, como por exemplo, engavetamentos, manobras bruscas e presença de veículos de emergência, além desses incidentes agravarem mais ainda as situações de tráfego intenso, como mostrado na Figura 3.25.
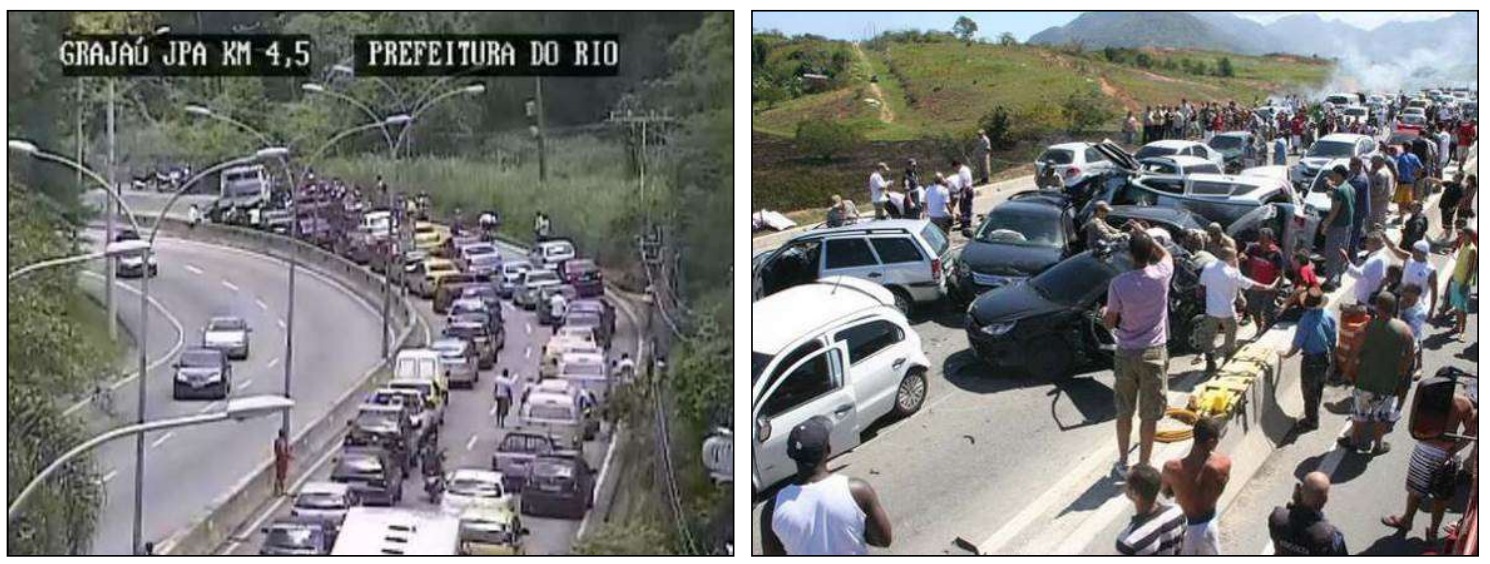

Figura 3.25: Exemplos de acidentes causados por congestionamentos em estradas do estado do Rio de Janeiro.

Fonte: G1, 2012. 
Muitos detalhes ainda não são compreendidos na ligação entre os congestionamentos e a segurança. Entretanto, o FHWA (2003) relata que:

- O potencial de ocorrência de acidentes provavelmente aumenta quando há o aumento de congestionamento;

- Existe uma baixa proporção de acidentes envolvendo um único veículo e um alto índice de ocorrências quando se envolvem mais de um veículo em situações de congestionamento;

- A severidade dos acidentes é menor durante as situações de congestionamento, em decorrência da baixa velocidade de tráfego dos veículos.

Em virtude do que foi exposto e diante da adoção de programas voltados para a redução de congestionamentos deve ser aliada às estratégias voltadas a redução da severidade de acidentes e dos acidentes envolvendo apenas um veículo.

\subsection{VELOCIDADE}

Para Sanchez (2001), quando se analisa o efeito da velocidade na segurança de tráfego, devese relacionar, principalmente, o tempo de percepção, o campo visual, as condições da pista e as consequências dos impactos.

A relação entre velocidade e segurança deve ser abordada em três aspectos (TRB: 1998 e GRSP: 2008). Uma primeira abordagem considerando que a capacidade do indivíduo na percepção e processamento de informações sobre situações perigosas diminua ao se aumentar a velocidade de circulação, como exemplificado na Tabela 3.5, que mostra a relação entre as velocidades do motorista e os ângulos de visão. Quando o ângulo de visão se reduz a $30^{\circ}$ ocorre o fenômeno chamado de "efeito de túnel", impedindo o motorista de perceber estímulos de áreas próximas à pista.

Tabela 3.5: Relação entre a velocidade do motorista e o ângulo de visão.

\begin{tabular}{c|c}
\hline Velocidade do motorista $(\mathbf{k m} / \mathbf{h})$ & $\hat{\text { Angulo de visão }\left(^{(}\right)}$ \\
\hline $\mathbf{0}$ & 180 \\
$\mathbf{3 5}$ & 104 \\
$\mathbf{1 0 0}$ & 42 \\
$\mathbf{1 3 0}$ & 30 \\
\hline
\end{tabular}

Fonte: Adaptado de Sampedro, 2010. 
A segunda abordagem assume que a probabilidade de um motorista se envolver em um acidente é função da diferença entre sua velocidade individual e a velocidade dos outros motoristas e a terceira abordagem está a associada à percepção do risco do motorista $\mathrm{e}$ considera que ao elevarem as velocidades os motoristas não necessariamente aumentam o risco de se envolver em acidentes.

Estudos realizados por TRB (1998) mostram a relação existente entre a dispersão da velocidade dos veículos e a frequência dos acidentes. O número de acidentes e a severidade estão proporcionalmente relacionados com o diferencial entre as velocidades de circulação desenvolvidas pelos veículos, ou seja, a presença de veículos lentos e rápidos no fluxo de tráfego.

Ao fazer a ligação entre a velocidade e a severidade dos acidentes, o NCHRP (1993) relata que há um aumento na severidade quando ocorre o aumento da velocidade de circulação da via. Isso se deve ao fato da energia cinética ser liberada pelo veículo, dependente da velocidade a qual este trafega. Ao relatar a probabilidade de morte, GRSP (2008) demonstra que, ao transitar a $80 \mathrm{~km} / \mathrm{h}$, os ocupantes de um veículo têm 20 vezes mais chance de morte do que ao se chocar a $30 \mathrm{~km} / \mathrm{h}$. No caso de atropelamentos, $85 \%$ destes ocorridos a velocidades superiores a $50 \mathrm{~km} / \mathrm{h}$ resultam em morte e, acima de $65 \mathrm{~km} / \mathrm{h}$, a porcentagem sobe para $100 \%$. A probabilidade de conflitos é maior a velocidades baixas, porém os acidentes tendem a ser menos severos.

ETSC (2008) indica que a melhor medida para reduzir a severidade e a quantidade de acidentes na Alemanha é a redução da velocidade, uma vez que a qualidade dos veículos e as condições da infraestrutura da região são relativamente boas no país. Outro debate posto em questão é a obrigação de um limite de velocidade através da rede Autobahn, conhecida por ser ilimitada, uma vez que há uma evidência empírica indicando que todas as autoestradas alemãs que foram limitadas apresentaram grandes reduções de vítimas fatais.

Entretanto, o FHWA (2008b) demonstra que o aumento do limite de velocidade em vias interestaduais do estado de Indiana, Estados Unidos, causou um acréscimo de acidentes tanto na quantidade, quanto na severidade. Isso se deve ao fato de que o aumento dos limites de velocidade causa um aumento do diferencial entre a velocidade dos veículos. 
Uma pesquisa da Organização de Cooperação e de Desenvolvimento Econômico (OCDE), referenciada por Sanchez (2001), afirma que para cada $\mathrm{km} / \mathrm{h}$ de acréscimo da velocidade, a acidentalidade aumenta 2\%. Assim, estima-se que uma redução de $5 \mathrm{~km} / \mathrm{h}$ nos limites de velocidade nas vias da União Europeia evitaria 11.000 mortes e 180.000 vítimas por ano. A relação entre a velocidade e a severidade dos acidentes pode ser observada na Figura 3.26.

Vale ressaltar que, deve-se adotar uma velocidade de projeto que cumpra as expectativas dos usuários das vias no que diz respeito à segurança, conforto e economia. Deste modo, velocidades de projeto muito baixas tendem a fazer com que os motoristas excedam com uma frequência maior os limites de velocidade estabelecidos, elevando assim os índices de acidentalidade (IMT: 2002).

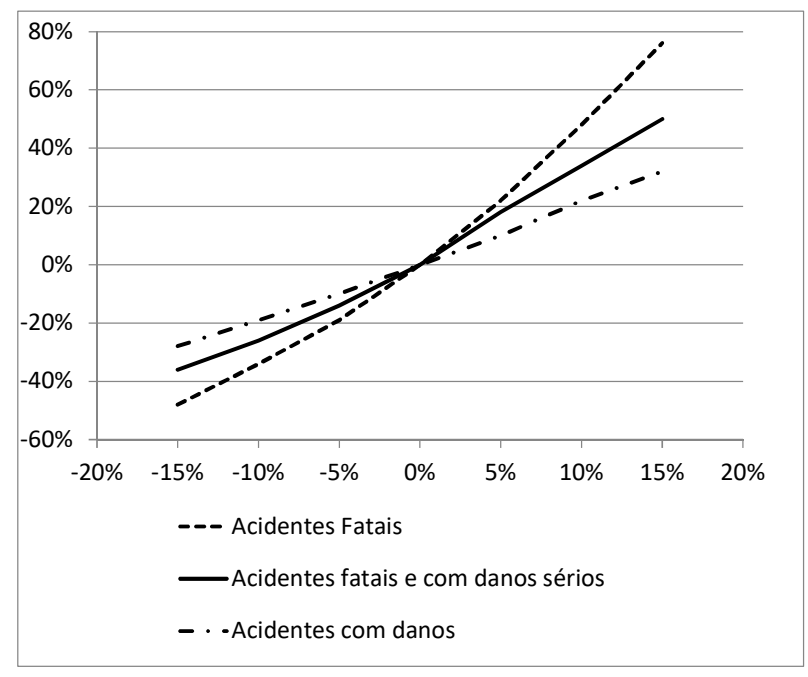

Figura 3.26: Relação entre a variação da velocidade e a variação dos acidentes.

Fonte: Adaptado de GRSP (2008).

\subsection{VEGETAÇÃO}

Outro potencial para a ocorrência de acidentes é a vegetação. Árvores funcionam como objetos fixos próximos às estradas, o crescimento rápido de grama, ervas, arbustos e galhos de árvores podem limitar ou dificultar a visão do motorista dos dispositivos de sinalização e controle de tráfego. 
O FHWA (2008a) lista uma série de alternativas que o controle da vegetação deve levar em conta:

- Manutenção da visibilidade da sinalização viária;

- Manutenção da visibilidade dos usuários (veículos, bicicletas e pedestres) e animais frente aos motoristas e vice-versa;

- Manutenção das calçadas em condições boas para os pedestres;

- Retirada de árvores que funcionam como objetos fixos perto das estradas que poderiam resultar em acidentes;

- Auxílio dos projetos de drenagem e preservação do pavimento.

Alguns problemas causados pela falta de manutenção são mostrados na Figura 3.27.

Deve-se também incluir a utilização de vegetação em contenção de taludes de aterro e corte, uma vez que a ausência do revestimento vegetal aliada ao processo erosivo natural do talude pode resultar em deslizamentos constantes do solo, causando danos irreparáveis ao corpo estradal, seja ocasionando sérios acidentes até contribuir para o assoreamento dos corpos d'água e obras de arte recorrentes (DNIT: 2009). 

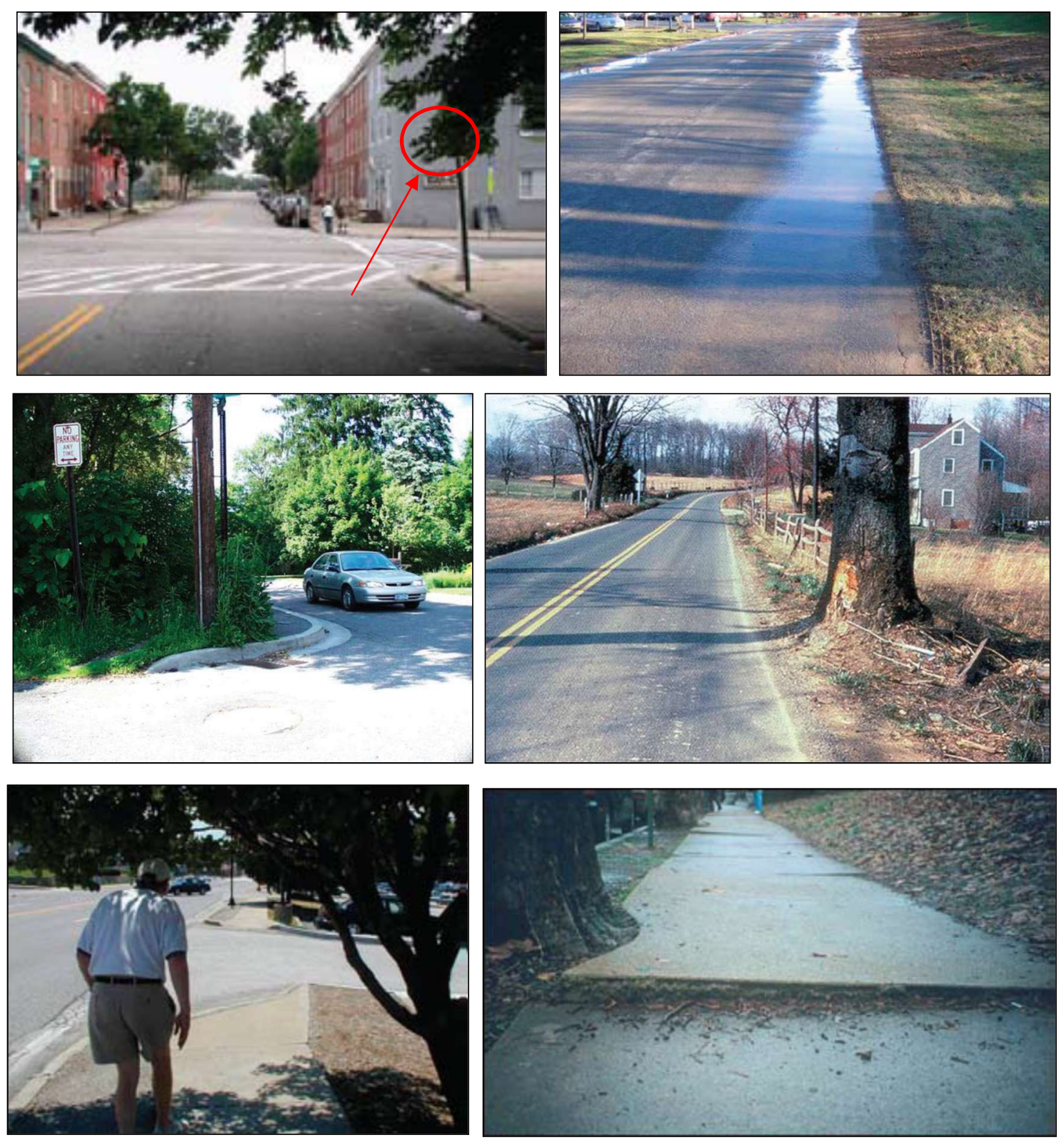

Figura 3.27: Problemas originados pela falta de controle da vegetação. Fonte: FHWA (2008a). 


\section{CONSISTÊNCIA GEOMÉTRICA}

O método de análise da consistência do projeto geométrico de rodovias se baseia em dois núcleos básicos:

- Modelos de estimativa de velocidade operacional;

- Critérios de classificação dos segmentos.

Os modelos de estimativa de velocidade, dadas as características geométricas das vias, fornecem um perfil (diagrama) de velocidades. Os critérios classificatórios usam este perfil para uma comparação entre as situações que seriam mais ou menos favoráveis.

Os modelos de estimativa de velocidade operacional variam de acordo com as características do país, com a forma funcional dos modelos e com as variáveis empregadas. Sendo assim, existe uma quantidade bastante expressiva do número de modelos de estimativa de velocidade operacional. No entanto, tal observação não ocorre com os critérios de classificação, pois possuem baixa variação entre diversos estudos. Neste capitulo, serão abordados os principais modelos de estimativa de velocidade operacional, os critérios classificatórios mais conhecidos e o método da consistência geométrica segundo o Interactive Highway Safety Design Model - IHSDM.

\subsection{MODELOS DE ESTIMATIVA DA VELOCIDADE OPERACIONAL}

Entende-se que a análise da consistência do projeto geométrico das rodovias é o estudo de como a via está sendo utilizada efetivamente. A melhor medida do comportamento associado ao condutor, rodovia e veículo e as suas inter-relações é a velocidade empregada em condição de fluxo livre. Assim sendo, o diagrama de velocidades operacionais de um trecho viário fornece alguns indicativos de como a geometria da via está associada ao padrão cultural do condutor e às características técnicas do veículo, identificando se há um equilíbrio dos elementos geométricos. Uma parte da análise da consistência geométrica consiste na comparação deste diagrama de velocidades com a velocidade de projeto. 
Os elementos geométricos das rodovias estão relacionados à velocidade de projeto, uma vez que as condicionantes geométricas decorrem da definição por norma de valores limites máximos e mínimos a partir da classe da rodovia, do relevo da região e das características do veículo padrão que levam a definição da velocidade de projeto.

A maioria dos projetistas tende a utilizar condicionantes geométricas com valores superiores aos definidos como limite pela norma, especialmente no que se refere às curvas horizontais. Apesar de tal procedimento oferecer um "sentimento de se ir a favor da segurança", o padrão de utilização pelo condutor da via é alterado.

A velocidade operacional $\left(\mathrm{V}_{85}\right)$ é a informação mais representativa de como os condutores utilizam a via em cima de determinadas condições geométricas. Os modelos de estimativa da $\mathrm{V}_{85}$ buscam uma relação de causa e efeito entre as características das rodovias e a velocidade operacional observada.

\subsubsection{Modelo de Lamm et al. (1990)}

Lamm et al. (1990) propõem um modelo resultado de estudos realizados entre 1984 e 1987 em rodovias de pista simples do estado de Nova Iorque, nos Estados Unidos. O trabalho foi desenvolvido considerando uma base de dados com 322 segmentos de curvas com diferentes raios. No entanto, o trabalho se limitava a alguns critérios pré-definidos, como por exemplo, inexistência de interseções, greides iguais ou inferiores a 5\%, e um volume diário médio anual entre 400 e 5000 veículos por dia. A condição de fluxo livre foi medida considerando os veículos com um gap superior a 6 segundos.

Foram consideradas as seguintes características (variáveis independentes) para a determinação de um modelo para a velocidade operacional:

- Taxa angular de curvatura;

- Largura da pista;

- Largura do acostamento;

- Declividade longitudinal;

- Distância de visibilidade;

- Comprimento da curva;

- Volume diário médio anual. 
A partir dessas variáveis independentes foi proposto o modelo preliminar obtido pelo método de regressão linear múltipla, apresentado pela Equação 1:

$$
\mathrm{V}_{85}=35,700-1,005 \times \mathrm{DC}+2,081 \times \mathrm{LW}+0,174 \mathrm{SW}+0,004 \times \mathrm{AADT}
$$

sendo:

$$
\begin{aligned}
\mathrm{V}_{85} & =\text { velocidade desenvolvida por } 85 \% \text { dos usuários da via no segmento estudado } \\
& \quad[\text { milhas } / \mathrm{h}]
\end{aligned}
$$

AADT = volume diário médio anual [veículos/dia].

A equação proposta pelo método apresenta um elevado coeficiente de determinação $\left(\mathrm{R}^{2}=0,842\right)$, o que permite estimar a velocidade operacional (variável dependente) através das variáveis independentes. As variáveis declividade longitudinal, distância de visibilidade e comprimento de curva não aparecem no modelo, uma vez que, em um nível de confiança de $95 \%$, tais variáveis não são significativas.

Lamm et al. (1990) resolveram simplificar o modelo apresentado na Equação 1, considerando apenas a taxa angular de curvatura como variável independente. Tal procedimento foi adotado uma vez que as demais variáveis obtiveram uma pequena contribuição (5,5\%) para o modelo. A Equação 2 relaciona a velocidade operacional e a taxa angular da curvatura de curvas horizontais:

$$
\mathrm{V}_{85}=58,656-1,135 \times \mathrm{DC}
$$

sendo:

$$
\begin{aligned}
& \mathrm{V}_{85}=\text { velocidade desenvolvida por } 85 \% \text { dos usuários da via no segmento estudado } \\
& \quad[\text { milhas } / \mathrm{h}] \\
& \mathrm{DC}=\text { taxa angular de curvatura }[\% / 100 \text { pés }] .
\end{aligned}
$$


Este modelo simplificado apresentou um coeficiente de determinação menor que o da Equação 1, porém ainda assim com valor elevado $\left(\mathrm{R}^{2}=0,787\right)$. Lamm et al. (1990) consideraram este modelo em seu estudo como o mais representativo, uma vez que o modelo é simples e consegue relacionar a velocidade operacional com a taxa angular de curvatura.

Lamm et al. (1990) ainda realizaram a conversão da taxa angular de curvatura para o raio da curva pela relação da Equação 3:

$$
\mathrm{DC}=\frac{360}{2 \times \pi \times \mathrm{R}}
$$

sendo:

$$
\begin{aligned}
& \mathrm{DC}=\text { taxa angular de curvatura [\%/100 pés]; } \\
& \mathrm{R}=\text { raio da curva [pés]. }
\end{aligned}
$$

Sendo 1 milha inglesa equivalente a 1,609 quilômetros e 1 pé, 0,3048 metros, a Equação 2 pode ser representada pela Equação 4:

$$
V_{85}=94,398-\frac{3188,656}{R}
$$

sendo:

$\mathrm{V}_{85}=$ velocidade desenvolvida por $85 \%$ dos usuários da via no segmento estudado $[\mathrm{km} / \mathrm{h}]$

$\mathrm{R}=$ raio da curva $[\mathrm{m}]$

É importante observar que a Equação 4, para raios que tendem ao infinito, ou seja, em tangentes, adotam uma velocidade operacional igual a 94,398 quilômetros por hora como velocidade máxima adotada pela maioria dos motoristas, sem quaisquer restrições legais a dadas condições de pista.

Lamm et al. (1990) analisaram, também, a velocidade operacional em pavimentos molhados e constataram que, para o motorista comum, não existe uma diferença estatística em relação a pavimentos secos. Entretanto, é de conhecimento geral que o atrito entre o pneu e o pavimento é reduzido quando há água na pista, acarretando problemas sérios de segurança. 
Sendo assim, o modelo sugerido no estudo apresenta o raio da curva (ou a taxa angular de curvatura) como única variável independente.

\subsubsection{Modelo de Garcia (2008)}

Tendo conhecimento que a maioria dos modelos de previsão da velocidade operacional utiliza como variável o inverso do raio planimétrico, Garcia (2008) realizou uma análise utilizando apenas veículos de passeio e apresentou um modelo econométrico de regressão linear simples e forma funcional inversa, conforme Equação 5:

$$
V_{85}=91,508-\frac{1883,440}{R}
$$

sendo:

$\mathrm{V}_{85}=$ velocidade operacional $[\mathrm{km} / \mathrm{h}]$;

$\mathrm{R}=$ raio da curva $[\mathrm{m}]$.

Para ampliar a abrangência do modelo da Equação 5, as variáveis independentes adicionais dummy lado, valor absoluto da declividade e dummy aclive foram inseridas e chegou-se ao modelo da Equação 6 por meio de uma análise multivariada:

$$
V_{85}=93,1545-\frac{1666,1716}{R}-1,1872 \times L-0,4654 \times|I|-1,3426 \times A
$$

sendo:

$\mathrm{V}_{85}=$ velocidade operacional $[\mathrm{km} / \mathrm{h}]$;

$\mathrm{R}=$ raio da curva $[\mathrm{m}]$;

$\mathrm{L}=$ dummy lado [1 - esquerda, 0 - direita ou sem curva $]$;

$\mathrm{I}=$ declividade $[\%]$

$\mathrm{A}=$ dummy aclive $[1$ - aclive, 0 - declive ou em nível $]$.

Ao se comparar os coeficientes de determinação das Equações 5 e 6, é observado um pequeno acréscimo na última, fazendo com que a Equação 6 explique melhor a variabilidade da velocidade operacional. 
O modelo expresso pela Equação 6 tem significância estatística, utiliza variáveis independentes reconhecidas, possui coeficiente de determinação satisfatório e não apresenta resíduos de variação em função das variáveis independentes, ou seja, o modelo é válido.

\subsection{CLASSIFICAÇÃO DOS SEGMENTOS DE ACORDO COM SUA CONSISTÊNCIA}

A concepção de um projeto geométrico, por anos, foi desenvolvida em cima de duas condicionantes:

a) Atendimento a normas existentes;

b) Restrições orçamentárias.

$\mathrm{O}$ atendimento às normas existentes limitava critérios mínimos de segurança dentro do projeto, ao passo que as restrições orçamentárias ditavam seus limites máximos. Com o advento dos dispositivos computacionais, várias horas que eram utilizadas para o cálculo foram reduzidas a frações de segundos. Com isso, sobrava tempo para os projetistas utilizarem melhores ferramentas para enquadrar o projeto dentro das restrições.

A análise de um projeto geométrico sob a perspectiva de sua efetiva utilização consiste em verificar se este está desempenhando a função esperada na etapa de definição do mesmo com foco nas duas condicionantes básicas anteriores. Um exemplo típico deste fato decorre da tentativa de projetistas oferecerem, isoladamente, melhores condições viárias.

Segundo o DNER (1999), um projeto viário de Classe III em região montanhosa implica a adoção de uma velocidade de projeto de $40 \mathrm{~km} / \mathrm{h}$. Sendo assim, têm-se que todos os parâmetros geométricos sejam dimensionados a partir desta velocidade. À medida que o projetista responsável consiga oferecer ao projeto elementos planimétricos bem acima dos limites mínimos estabelecidos na norma, é de senso comum afirmar que o projeto apresentaria uma melhor condição de segurança.

No entanto, raios mais amplos, por exemplo, podem alterar o padrão de comportamento do condutor, de forma a elevar sua velocidade. O projetista não percebe que todos os demais elementos geométricos permanecem dimensionados para a velocidade de $40 \mathrm{~km} / \mathrm{h}$, quando esta não é mais a referência para este projeto. Logo, tem-se, neste caso hipotético, sérios problemas de dimensionamento (superelevação, superlargura e distâncias de visibilidade) 
que implicam em problemas de segurança.

São recomendados três grupos de classificação de projetos viários:

Critério de segurança I: critério da diferença entre a velocidade operacional e a velocidade de projeto - Consistência do projeto.

Critério de segurança II: critério da diferença entre as velocidades operacionais em curvas sucessivas - Consistência da velocidade operacional.

Critério de segurança III: coeficiente de atrito no dimensionamento da superelevação.

\subsubsection{Critério de segurança I}

Lamm et al. (1990) consideraram a possibilidade da classificação de um projeto em três níveis diferentes, de acordo com a diferença apresentada entre a velocidade de projeto e a velocidade operacional. O mesmo critério é adotado e recomendado na Alemanha e Estados Unidos (LAMM et al.: 1995; FHWA: 2000b; LAMM et al.: 1999). O projeto geométrico ao ser analisado por este critério pode apresentar três condições distintas:

1) Projeto bom: É a condição ideal entre o projeto e a utilização da via. Neste caso, o módulo da diferença entre a velocidade operacional e a velocidade de projeto não é superior a $10 \mathrm{~km} / \mathrm{h}\left(\left|\mathrm{V}_{85}-\mathrm{V}_{\mathrm{d}}\right| \leq 10 \mathrm{~km} / \mathrm{h}\right)$. Segmentos de rodovias que se enquadram neste caso não necessitam de adaptações ou correções em seu traçado.

2) Projeto regular: Esta condição ocorre para diferenças de velocidade entre 10 a $20 \mathrm{~km} / \mathrm{h}$ $\left(10 \mathrm{~km} / \mathrm{h} \leq\left|\mathrm{V}_{85}-\mathrm{V}_{\mathrm{d}}\right| \leq 20 \mathrm{~km} / \mathrm{h}\right)$. As curvas classificadas neste intervalo deverão sofrer adaptações, a fim de reestabelecer as condições de segurança idealizadas em projeto. Para tanto, deve-se utilizar como referência a velocidade operacional, e não mais a velocidade de projeto. Geralmente há uma necessidade de correção da superelevação para reequilibrar a curva. Sérios problemas de dimensionamento são observados nesta condição.

3) Projeto fraco: Condição observada nas situações onde a diferença entre a velocidade operacional e a velocidade diretriz é superior a $20 \mathrm{~km} / \mathrm{h}\left(\left|\mathrm{V}_{85}-\mathrm{V}_{\mathrm{d}}\right|>20 \mathrm{~km} / \mathrm{h}\right)$. Quando tal efeito é observado deve-se reprojetar para estabelecer as condições mínimas de segurança para o padrão de utilização. 


\subsubsection{Critério de segurança II}

O DNER (1999) utiliza a recomendação de raios sucessivos apresentada na Figura 4.1. O mesmo ábaco, com pequenas alterações, pode ser encontrado nas normas de projeto geométrico da Alemanha e Grécia. Pela Figura 4.1, pode-se observar que, para uma curva de raio de 400 metros, o intervalo de raios para uma sucessão desejável é de 330 a 510 metros, aproximadamente. Já uma sucessão considerada boa permitiria um intervalo maior, entre 270 e 640 metros, e uma sucessão aceitável apresentaria, como limites mínimo e máximo, 250 e 800 metros, respectivamente. Valores fora desta última faixa devem ser evitados.

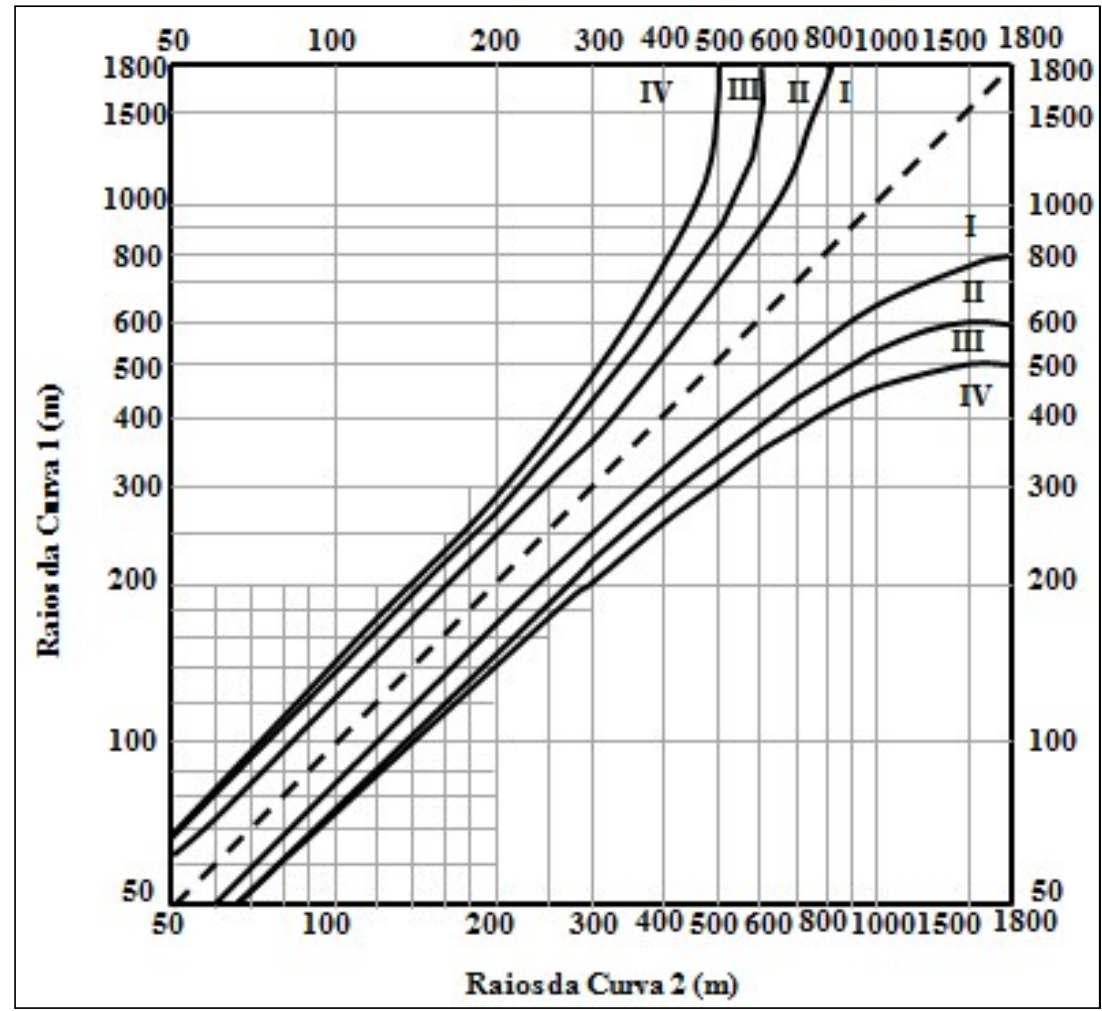

Zona I - Sucessão desejável

Zona II - Sucessão boa

Zona III - Sucessão aceitável

Zona IV - Sucessão a evitar quando possível

Figura 4.1: Critérios desejáveis para orientar a escolha dos raios de curvas sucessivas. Fonte: adaptado de DNER (1999).

Da forma equivalente se dá o objetivo da análise de curvas sucessivas a partir da variação da velocidade operacional. A Figura 4.2 apresenta seis condições básicas da variação da velocidade ao longo de duas curvas consecutivas. Para tanto, admite-se que ao longo da curva circular a variação da velocidade é desprezível, fazendo com que as acelerações e desacelerações ocorram apenas nos trechos em reta. 

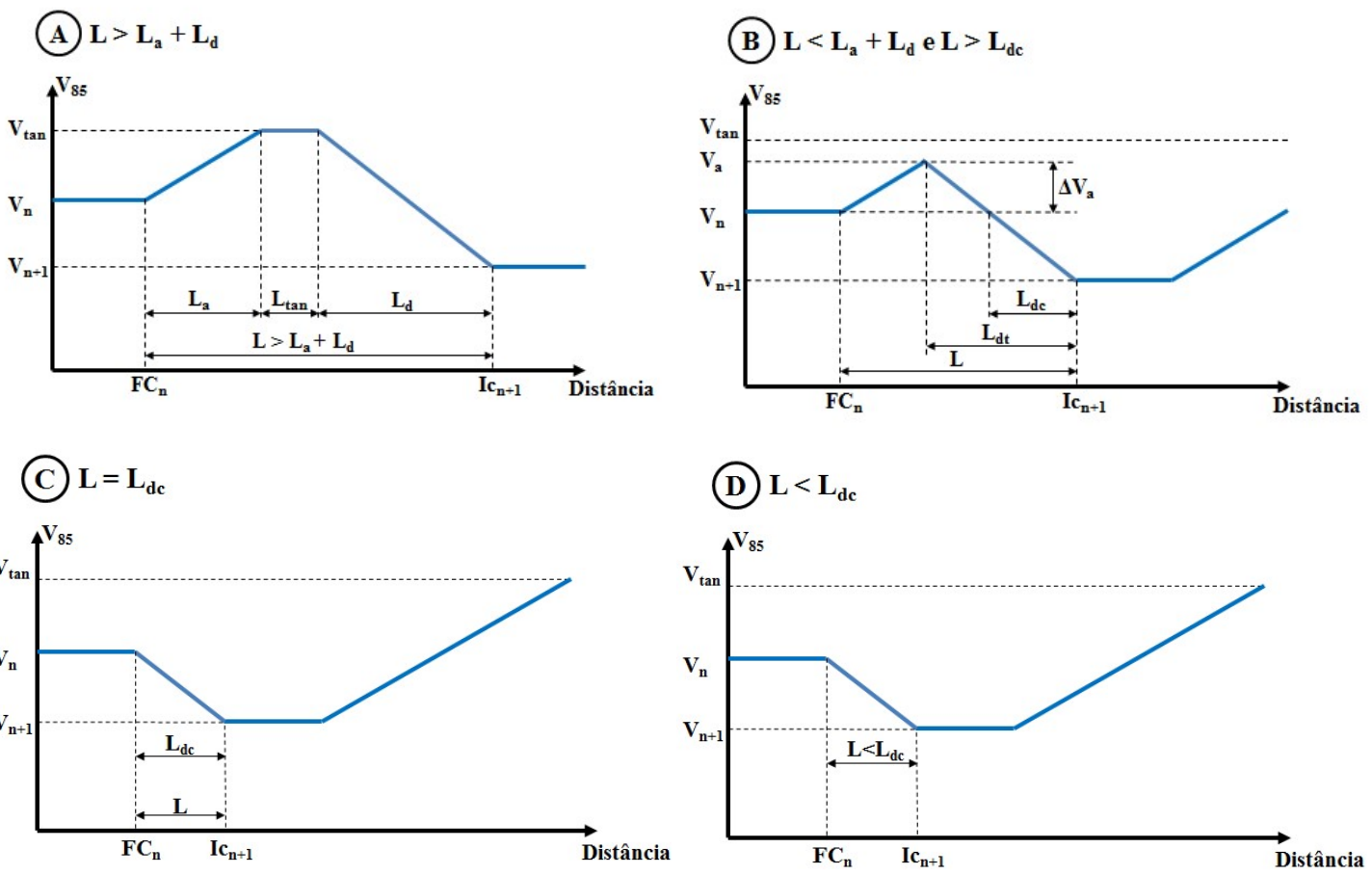

(E) $\mathbf{L} \geq \mathbf{L}_{\mathbf{a c}}$

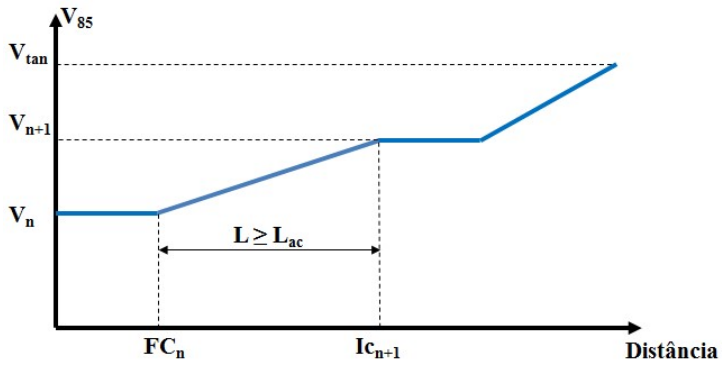

(F) $\mathbf{L}<\mathbf{L}_{\mathbf{a c}}$

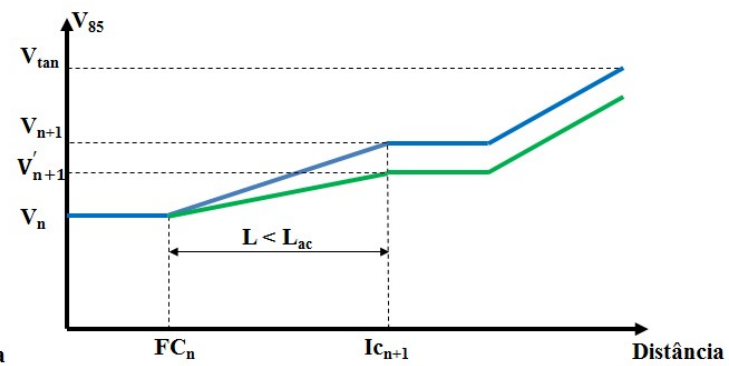

\begin{tabular}{|c|c|}
\hline $\begin{array}{l}\mathbf{V}_{\tan } \\
\mathbf{V}_{\mathrm{n}} \\
\mathbf{V}_{\mathrm{n}+1} \\
\mathbf{V}_{\mathrm{a}} \\
\mathbf{\Delta} \mathbf{V}_{\mathrm{a}} \\
\mathbf{L} \\
\mathbf{L}_{\mathrm{a}} \\
\mathbf{L}_{\mathbf{d}} \\
\mathbf{L}_{\mathrm{tan}} \\
\mathbf{L}_{\mathrm{dt}} \\
\mathbf{L}_{\mathrm{dc}} \\
\mathbf{L}_{\mathrm{ac}} \\
\mathbf{F C} \\
\mathbf{I} \mathbf{c}_{\mathrm{n}+1}\end{array}$ & $\begin{array}{l}: V_{85} \text { para longas tangentes } \\
: V_{85} \text { da curva ' } n \text { ' } \\
: V_{85} \text { da curva ' } n+1 \text { ' } \\
: V_{85} \text { máxima atingida na condição } B \\
: \text { diferença entre o a } V_{85} \text { da curva ' } n \text { ' e a } V_{85} \text { máxima entre curvas na condição } B \\
\text { :comprimento entre duas curvas sucessivas } \\
\text { :comprimento necessário para atingir } V_{t a n} \text {, partindo de } V_{n} \text {, em aceleração } \\
\text { :comprimento necessário para atingir } V_{t a n} \text {, partindo de } V_{n} \text {, em desaceleração } \\
\text { :comprimento entre curvas percorrido por } V_{\text {tan }} \\
\text { :comprimento necessário para atingir } V_{n+1} \text {, partindo de } V_{a} \text {, em desaceleração } \\
\text { :comprimento em desaceleração entre curvas } \\
\text { :comprimento em aceleração entre curvas } \\
\text { :final da curva ' } n \text { ' } \\
\text { :início da curva ' } n+1 \text { ' }\end{array}$ \\
\hline
\end{tabular}

Figura 4.2: Condições de aceleração e desaceleração entre curvas sucessivas. Fonte: adaptado de FHWA (2000b).

Conforme a condição do comprimento da tangente, da velocidade operacional na primeira curva, da velocidade operacional na curva subsequente, das taxas de aceleração e desaceleração, seis situações distintas podem ser observadas: 
- Condição A: Indica que, após desenvolver a primeira curva, o condutor pode atingir a velocidade operacional em segmento de reta, e, em seguida, passa a reduzir conforme a percepção das condições oferecidas pela curva seguinte. Nesta condição, não existe influência da velocidade operacional da primeira curva em cima da velocidade operacional da segunda curva.

- Condições B, C e D: Nestas condições são representados processos de desaceleração entre duas curvas subsequentes, cada uma delas com transições diferentes. Na condição B, o condutor desenvolve aceleração de um veículo por um trecho e em seguida desacelera. Na condição $\mathrm{C}$ são consideradas taxas de desaceleração favoráveis (entre $1,00 \mathrm{~m} / \mathrm{s}^{2}$ e $1,48 \mathrm{~m} / \mathrm{s}^{2}$ ). Na condição $\mathrm{D}$, a curva tem comprimento insuficiente para garantir a desaceleração em um nível favorável em detrimento a segurança viária.

- Condições E e F: Nestas condições, existe a retomada do processo de aceleração em condições favoráveis $(\mathrm{E})$ e em não favoráveis $(\mathrm{F})$, considerados entre os valores de $0,54 \mathrm{~m} / \mathrm{s}^{2}$ e $0,89 \mathrm{~m} / \mathrm{s}^{2}$.

A utilização de modelo de estimativa da velocidade operacional permite a identificação da mesma para um conjunto de raios planimétricos. A análise da variação desta velocidade ao longo de uma rodovia possibilita classificar a mesma em três casos distintos:

- Projeto bom: É a condição ideal entre projeto e utilização da via. Neste caso, o módulo da diferença entre as velocidades operacionais de elementos planimétricos sucessivos (curva-curva, tangente-curva) é inferior ou igual a $10 \mathrm{~km} / \mathrm{h}\left(\left|\mathrm{V}_{85 \mathrm{i}}-\mathrm{V}_{85(\mathrm{i}+1)}\right| \leq 10 \mathrm{~km} / \mathrm{h}\right)$. Segmentos de rodovias que se enquadram neste caso não necessitam de adaptações ou correções em seu traçado.

- Projeto regular: Ocorre quando o módulo da diferença entre as velocidades operacionais está no intervalo entre 10 a $20 \mathrm{~km} / \mathrm{h}\left(10 \mathrm{~km} / \mathrm{h}<\left|\mathrm{V}_{85 \mathrm{i}}-\mathrm{V}_{85(\mathrm{i}+1)}\right| \leq 10 \mathrm{~km} / \mathrm{h}\right)$. As curvas e tangentes que se encontram neste intervalo apresentam problemas de inconsistência geométrica que poderão ser resolvidos mediante sinalização apropriada, não necessitando de reprojeto.

- Projeto fraco: esta condição ocorre quando a diferença de velocidades operacionais superior em $20 \mathrm{~km} / \mathrm{h},\left(\left|\mathrm{V}_{85 i}-\mathrm{V}_{85(\mathrm{i}+1)}\right|>20 \mathrm{~km} / \mathrm{h}\right)$. Determina uma condição de projeto com problemas sérios de fluidez. Curvas que apresentam diferenças desta ordem devem 
ser reprojetadas, de forma a restabelecer a consistência dos diferentes elementos geométricos sucessivos.

\subsubsection{Critério de segurança III}

Lamm et al. (1995) apresentam como um terceiro critério de análise, a classificação de um projeto geométrico segundo a diferença entre o coeficiente de atrito transversal adotado e o coeficiente de atrito efetivo. A Tabela 4.1 apresenta as Equações 7 a 10 que reproduzem as condições de coeficiente de atrito adotado e efetivo, obtidos dos estudos de Lamm et al. (1995) na Alemanha e nos Estados Unidos.

Tabela 4.1: Modelos para estimativa do coeficiente de atrito adotado e efetivo na Alemanha e nos Estados Unidos

\begin{tabular}{c|lcc}
\hline País & \multicolumn{1}{|c}{ Modelo } & $\boldsymbol{R}^{2}$ & Equação \\
\hline \multirow{2}{*}{ Alemanha } & $\mathrm{f}_{\mathrm{r}}=0,078+7,95 \times 10^{-3} \times \mathrm{DC}-2,9 \times 10^{-4} \times \mathrm{DC}^{2}$ & 0,408 & $(7)$ \\
& $\mathrm{f}_{\mathrm{rd}}=0,023+2,02 \times 10^{-2} \times \mathrm{DC}-4,7 \times 10^{-4} \times \mathrm{DC}^{2}$ & 0,679 & $(8)$ \\
& $\mathrm{f}_{\mathrm{r}}=0,092+8,10 \times 10^{-3} \times \mathrm{DC}-2,3 \times 10^{-4} \times \mathrm{DC}^{2}$ & 0,887 & $(9)$ \\
Estados Unidos & $\mathrm{f}_{\mathrm{rd}}=0,014+2,25 \times 10^{-2} \times \mathrm{DC}-5,7 \times 10^{-4} \times \mathrm{DC}^{2}$ & 0,864 & $(10)$ \\
\hline
\end{tabular}

Fonte: Lamm et al. (1988).

sendo:

$\mathrm{f}_{\mathrm{r}}=$ coeficiente de atrito adotado;

$\mathrm{f}_{\mathrm{rd}}=$ coeficiente de atrito efetivo;

$\mathrm{DC}=$ taxa angular de curvatura [\%/100 pés].

Pode-se classificar as curvas em três categorias distintas, a partir da utilização das equações 7 a 10:

- Projeto bom: É a condição ideal. Neste caso, a diferença entre o coeficiente de atrito adotado e o efetivo deve ser inferior a $+0,02$, ou seja, $f_{r}-f_{r d} \geq+0,02$. Segmentos de rodovias que se enquadram neste caso não necessitam de adaptações ou correções em seu traçado.

- Projeto regular: Ocorre quando a diferença entre o coeficiente de atrito adotado e o efetivo está entre $-0,02$ e $+0,02$, ou seja, $-0,02 \leq f_{r}-f_{r d}<+0,02$. As curvas e tangentes que se encontram neste intervalo apresentam problemas de inconsistência geométrica que 
poderão ser resolvidos mediante modificação da superelevação. Geralmente se faz o dimensionamento desta com $\mathrm{V}_{85}$.

- Projeto fraco: Esta condição ocorre quando a diferença de coeficiente de atrito adotado e efetivo inferior a $-0,02$, ou seja, $f_{r}-f_{r d}<+0,02$. Velocidades operacionais superior em $20 \mathrm{~km} / \mathrm{h}$, (| $\left.\mathrm{V}_{85 \mathrm{i}}-\mathrm{V}_{85(\mathrm{i}+1)} \mid>20 \mathrm{~km} / \mathrm{h}\right)$. Curvas que apresentam diferenças desta ordem devem ser reprojetadas.

\subsubsection{Classificação dos projetos segundo os critérios I, II e III}

A avaliação da consistência dos projetos geométricos a partir dos critérios I, II e III permite realizar a identificação dos problemas pontuais ou em toda a via. Lamm et al. (1995) propõem uma sistematização de análise dos projetos pressupondo uma separação classificada deles e, em cima disto, sugerem a classificação do Módulo de Segurança para Projetos Geométricos de Rodovias (Tabela 4.2).

Tabela 4.2: Classificação do Módulo de Segurança para Projetos Geométricos.

\begin{tabular}{cc}
\hline Classificação do Módulo de Segurança & Classificação segundo os Critérios I, II e III \\
\hline Projeto bom & 3 bons \\
& 2 bons e 1 regular \\
& 2 bons e 1 fraco \\
\hline Projeto regular & 3 regulares \\
& 2 regulares e 1 bom \\
& 2 regulares e 1 fraco \\
& 1 bom, 1 regular e 1 fraco \\
\hline Projeto fraco & 3 fracos \\
& 2 fracos e 1 bom \\
\end{tabular}

Fonte: Lamm et al (1995).

A partir da classificação das rodovias segundo o módulo de segurança proposto e as taxas de acidentes efetivas em segmentos viários de rodovias alemãs, Lamm et al. (1995) observaram uma relação entre taxas elevadas de acidentes e a classificação dos segmentos em projeto fraco. 


\subsection{ClassificaÇão dos PROJETOS ATRAVÉS do ICG}

O Índice de Consistência Geométrica (ICG) é um indicador de desempenho da consistência geométrica da via. Para isso, há a divisão dele em $\mathrm{ICG}_{\mathrm{km}}$ e $\mathrm{ICG}_{\text {trecho }}$ com os seguintes objetivos:

ICGkm: É o índice de consistência geométrica estimado por quilômetro. Serve para o ordenamento e classificação de diferentes segmentos de uma mesma via. Com o auxílio deste recurso, pode-se criar uma relação de prioridades nas intervenções de uma rodovia.

ICGtrecho: Apresenta uma dupla finalidade. Pode-se realizar uma comparação entre rodovias distintas, como também tem a função de valor de referência da rodovia que, ao confrontar com o $\mathrm{ICG}_{\mathrm{km}}$, identifica se o valor de um dado segmento é superior, inferior ou equivalente ao da rodovia.

\subsubsection{Pesos dos critérios de segurança I e II para a classificação}

Conforme visto no item 4.2 há três classificações (bom, regular e fraco) para os critérios de segurança I e II. Para criar um índice que utilize estes dois critérios, se fez necessária uma identificação de pesos para cada um dos níveis, procurando expressar de uma forma quantitativa uma variável qualitativa. Os critérios adotados para a obtenção dos pesos, neste estudo, foram:

- Indicar um peso alto para o nível de classificação "bom, intermediário para "regular" e baixo para "fraco", pois pretende-se relacionar a nota alta do ICG a uma situação desejável;

- Não trabalhar com escala linear na definição de pesos, penalizando a situação mais desfavorável e atribuindo a mesma uma nota significativamente mais baixa, de forma que a média entre a nota mais alta e a mais baixa seja inferior a nota intermediária, e;

- Utilizar pesos que produzam uma larga escala de amplitude, tendo-se um grande espectro de valores na classificação.

Assim sendo, utilizando os valores sugeridos por Garcia (2008), optou-se pelos pesos da Tabela 4.3. 
Tabela 4.3: Pesos dos níveis de classificação dos critérios de segurança I e II

\begin{tabular}{cc}
\hline Classificação & Peso \\
\hline Bom & 9 \\
Regular & 6 \\
Fraco & 1 \\
\hline
\end{tabular}

Fonte: Garcia (2008).

O valor zero não deve ser adotado no indicativo da pior situação devido à utilização da média geométrica, anulando completamente o efeito dos demais indicadores.

\subsubsection{Cálculo do critério de segurança composto $\left(\mathrm{CS}_{\mathrm{c}}\right)$}

Apesar do $\mathrm{ICG}_{\mathrm{km}}$ e do $\mathrm{ICG}_{\text {trecho }}$ serem valores únicos para determinados intervalos, os critérios de segurança I e II são obtidos para cada um dos sentidos da via (LD - lado direito ou sentido do estaqueamento, LE - lado esquerdo ou sentido contrário), em intervalos de $100 \mathrm{~m}$. Sendo assim, optou-se pela média geométrica, uma vez que, diferente da aritmética, penaliza a variabilidade dos dados e minimiza a compensação entre valores altos e baixos. Como exemplo tem-se que a média aritmética entre 1 e 9 é 5 e a média geométrica, 3.

A Equação 11 mostra como os critérios de segurança I e II por intervalos de $100 \mathrm{~m}$ são obtidos em função dos valores registrados para cada sentido da via:

$$
C S_{i}=\sqrt{C S_{i L E} \times C S_{i L D}}
$$

sendo:

$\mathrm{CS}_{\mathrm{i}}=$ critério de segurança i do intervalo de $100 \mathrm{~m}$ (I ou II);

$\mathrm{CS}_{\mathrm{iLE}}=$ critério de segurança i do intervalo de $100 \mathrm{~m}$ do lado esquerdo da via (I ou II);

$\mathrm{CS}_{\mathrm{iLD}}=$ critério de segurança i do intervalo de $100 \mathrm{~m}$ do lado direito da via (I ou II).

De maneira igual, o critério de segurança composto $\left(\mathrm{CS}_{\mathrm{C}}\right)$ é obtido a partir da média geométrica dos critérios de segurança I e II do intervalo de $100 \mathrm{~m}$ (Equação 12). O CS $\mathrm{S}_{\mathrm{C}}$ o elemento base para o cálculo do $\mathrm{ICG}_{\mathrm{km}}$ e $\mathrm{ICG}_{\text {trecho: }}$ : 


$$
C S_{i}=\sqrt{C S_{I} \times C S_{I I}}
$$

sendo:

$\mathrm{CS}_{\mathrm{C}}=$ critério de segurança composto do intervalo de $100 \mathrm{~m}$;

$\mathrm{CS}_{\mathrm{I}}=$ critério de segurança $\mathrm{I}$ do intervalo de $100 \mathrm{~m}$;

$\mathrm{CS}_{\mathrm{II}}=$ critério de segurança II do intervalo de $100 \mathrm{~m}$;

\subsubsection{Cálculo do ICGkm e ICGtrecho}

O cálculo do $\mathrm{ICG}_{\mathrm{km}}$ através do critério de segurança composto, calculado para intervalos de $100 \mathrm{~m}$, é obtido através da média geométrica destes últimos e de sua correção de amplitude, conforme Equação 13. É realizado o produtório dos dez valores de critérios de segurança compostos dos intervalos que compõem o quilômetro $(n=10)$. Como o valor superior é 9 e o inferior é 1, têm-se que a amplitude seja igual a 8. Sendo assim, subtrai-se uma unidade do produtório, corrigindo-se a amplitude, para se ter o valor mínimo da escala para zero. A divisão do resultado pela amplitude original e sua multiplicação por 100 resultam em uma escala de 0 a 100, desejada para o indicador ICG.

$$
I C G_{k m}=\frac{\sqrt[n]{\prod_{i=1}^{n} C S_{C i}}-1}{A} \times 100
$$

sendo:

$\mathrm{ICG}_{\mathrm{km}}=$ índice de consistência geométrica por quilômetro, com amplitude de 0 a 100;

$\mathrm{CS}_{\mathrm{Ci}}=$ critério de segurança composto;

$\mathrm{n}=$ intervalo considerado $(\mathrm{n}=10)$;

$\mathrm{A}=\operatorname{amplitude}(\mathrm{A}=$ peso máximo 9 menos o peso mínimo $1=8)$.

Os principais objetivos do $\mathrm{ICG}_{\text {trecho }}$ são a classificação e a ordenação de trechos viários de acordo com a sua consistência geométrica e, para isso, a definição do termo "trecho" se faz necessária. Geralmente, trechos viários de rodovias estão relacionados a intervalos quilométricos com características de relevo, de tráfego, de entorno e geométricas muito semelhantes entre si, comumente associados a acessos e interseções. Neste estudo, o termo "trecho" se refere a toda via em estudo. 
Como o $\mathrm{ICG}_{\text {trecho }}$ é decorrente da média geométrica dos $\mathrm{ICG}_{\mathrm{km}}$, alguns segmentos que não apresentem condições de avaliação pelo método podem ser desconsiderados e não serem incluídos na potência da raiz do produtório. Por outro lado, o $\mathrm{ICG}_{\text {trecho }}$ é um indicador do trecho viário como um todo e, ao se desconsiderar vários segmentos, pode-se comprometer o resultado final. Em casos mais críticos, recomenda-se utilizar apenas o indicador $\mathrm{ICG}_{\mathrm{km}} \mathrm{e}$

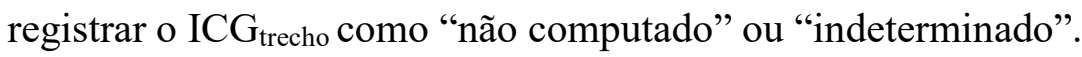

\subsubsection{Classificação do ICG $\mathrm{Im}$ e ICGtrecho}

Inicialmente foi apresentada uma classificação em cinco categorias distintas para as rodovias brasileiras (Tabela 4.4).

Tabela 4.4: Intervalos de classificação das características avaliadas.

\begin{tabular}{cc}
\hline Classificação & Intervalo \\
\hline Ótima & $91 \leq$ nota $\leq 100$ \\
Boa & $81 \leq$ nota $\leq 90$ \\
Regular & $56 \leq$ nota $\leq 80$ \\
Ruim & $41 \leq$ nota $\leq 55$ \\
Péssima & $0 \leq$ nota $\leq 40$ \\
\hline
\end{tabular}

Fonte: CNT,2006 apud GARCIA, 2008.

O FHWA (2000) sugere três categorias de classificação: Bom, regular e fraco. Sendo assim, de forma a compatibilizar a classificação do ICG, com intervalo de 0 a 100 , em três categorias e levando-se em conta os intervalos do CNT (2006), Garcia (2008) propôs a classificação de acordo com a Tabela 4.5

Tabela 4.5: Intervalos de classificação do ICG.

\begin{tabular}{cc}
\hline Classificação & Intervalo \\
\hline Bom & $81 \leq$ nota $\leq 100$ \\
Regular & $51 \leq$ nota $\leq 80$ \\
Fraco & $0 \leq$ nota $\leq 50$ \\
\hline
\end{tabular}

Fonte: Garcia (2008). 


\subsection{FERRAMENTAS DE ANÁLISE DO PROJETO GEOMÉTRICO}

Foi realizada uma pesquisa sobre as ferramentas que são utilizadas na área da Engenharia que projetam e analisam os Projetos Geométricos das rodovias. Serão apresentados neste item uma abordagem geral sobre os softwares InRoads, TransCAD, AutoCAD Civil 3D e IHSDM, de acordo com os documentos de natureza comercial de divulgação e apresentação, com o objetivo de mostrar as características e funcionalidades de cada software.

\subsubsection{AutoCAD Civil 3D}

O AutoCAD Civil 3D auxilia os engenheiros civis e profissionais da área a aperfeiçoar o desempenho dos projetos de construção. É composto de análise geoespacial para identificar as melhores opções de projeto, análise do aproveitamento de águas pluviais para projetos sustentáveis, cálculos dinâmicos de terraplanagem e inventário de quantidades. Aprimorando a utilização de materiais e visualizações 3D, possibilita uma melhor aferição dos impactos do projeto sobre o meio ambiente. O software oferece um suporte aos fluxos de trabalho de modelagem de informação da construção (BIM), melhorando a entrega do projeto e mantendo os dados todos reunidos em um único programa, podendo, assim, gerar uma maior rapidez às alterações dos projetos desenvolvidos. No entanto, o programa não apresenta as ferramentas de análise da consistência do projeto geométrico quando criado.

\subsubsection{Interactive Highway Safety Design Model - IHSDM.}

O software IHSDM é um produto da Federal Highway Administration's Safety Research and Development Program com ferramentas para análise da segurança e operação de rodovias de pista simples (IHSDM: 2006). O software simula um padrão de utilização da via a partir de dados de suas características geométricas e é possível analisar o projeto geométrico em uma fase anterior a sua implantação. Pode-se utilizar o $\operatorname{IHSDM}^{1}$ na análise de rodovias existentes, identificando pontos críticos e avaliando projetos alternativos. Para rodovias já implantadas o software permite a inclusão de dados adicionais, como seu volume diário médio e dados de acidentes, de forma a refinar suas estimativas.

\footnotetext{
${ }^{1}$ A versão 11.0.0 de setembro de 2015, utilizada para fins deste estudo está disponível em: $<$ http://www.ihsdm.org/wiki/Download_Login>. Para realizar o download gratuito é necessário um cadastro com os dados do interessado.
} 
O IHSDM possui dentre tantos alguns módulos de avaliação para análise da rodovia (Crash Prediction, Policy Review, Design Consistency, Driver/Vehicle).

- Crash Prediction Module - CPM: Estima a frequência dos acidentes esperados em uma rodovia conforme suas características de projetos e de tráfego. O CPM pode ser utilizado tanto em projetos em fase de planejamento, como nos já implementados, comparando seu desempenho na segurança em alternativas de projetos e assessorando as decisões para um projeto de melhor relação custo-benefício.

- Design Consistency Module - DCM: Parte da premissa básica de que os condutores cometem menos erros em zonas onde a geometria da via se adapta as suas expectativas, do que naquelas onde as características geométricas fogem, significativamente, do esperado. Desta forma, o bom projeto é aquele que, de forma equilibrada, repassa ao condutor uma percepção de segurança compatível com a que verdadeiramente oferece.

- Policy Review Module - PRM: Checa os elementos de projeto no segmento da rodovia para observar as normas estabelecidas. O módulo fornece arquivos eletrônicos replicando as normas especificadas pela AASHO nos anos de 1990, 1994, 20012004 e 2011 nas edições de A policy on geometric design of highways and streets, e correlaciona automaticamente os valores de projeto a esses valores normativos. O IHSDM também provê uma ferramenta para alterar os valores tabelados de forma a ajustar a análise para as normas de outros países.

- Driver/Vehicle Module: O objetivo deste módulo é permitir a avaliação de como um condutor opera um veículo dentro do contexto do projeto da rodovia e identificar se as condições existentes em um dado projeto podem resultar em uma perda de controle do veículo.

\subsubsection{Sistema Avançado para Estudos e Projetos Viários - Saepro}

O projeto "Diretrizes para o desenvolvimento de um sistema avançado para estudos e projetos viários" tem por objetivo principal identificar, caracterizar e hierarquizar os elementos e processos necessários à concepção, construção e manutenção de uma obra de infraestrutura viária (GARCÍA: 2014). 
O programa reúne e organiza os conhecimentos existentes tanto no estado da arte quanto no estado da prática para o desenvolvimento de uma plataforma de informática para estudos, projetos, construção, fiscalização, operação e análises de obras de infraestrutura viária.

A parceria estabelecida neste projeto integra diversos agentes do meio acadêmico (UFRGS) da iniciativa privada (CIENGE e STE) e de órgãos públicos. Esta pluralidade de pesquisadores, técnicos, fiscais entre outros, oferece uma visão de um mesmo problema sob diferentes perspectivas permitindo a análise e a sistematização dos procedimentos para a busca de soluções simples, ágeis e precisas. A diretriz do projeto é definida por:

- Missão: Criar, desenvolver e aprimorar soluções técnicas de engenharia relacionadas a obras de infraestrutura viária.

- Visão: Ser centro de excelência em pesquisa, projeto e capacitação em obras de infraestrutura viária e informática.

- Valores: Simplicidade, eficiência, precisão, integração e modularidade.

Os valores mencionados referem-se tanto ao projeto como à concepção da plataforma de informática em desenvolvimento e apresentam as seguintes características:

- Simplicidade: De operação é uma tendência mundial em informática, oferecendo GUIs (Graphical User Interface) mais simples e diretas. A capacitação acelera a curva de aprendizagem, diminuindo custos.

- Eficiência: Nos processos e resultados. Em obras de infraestrutura viária, principalmente em projetos, a eficiência está diretamente relacionada ao tempo demandado por um processo e aos resultados obtidos.

- Precisão: Matemática a serviço da engenharia. Possibilidade de definir a precisão requerida em um processo, bem como as tolerâncias adotadas.

- Integração: Entre as etapas e as atividades, através do conceito BIM, na definição de objetos, propriedades e eventos do sistema e com o meio externo, de forma a permitir a importação/exportação de dados de diferentes sistemas. 
- Modularidade: Permite a incorporação, alteração e subtração das partes de forma ágil, viabilizando a cooperação entre os diferentes desenvolvedores. O conceito de plataforma só é viável através do desenvolvimento modular do sistema.

O projeto "diretrizes para o desenvolvimento de um sistema avançado para estudos e projetos viários" (Saepro) oferece subsídios e delimita condicionantes para viabilizar o desenvolvimento de software específico para a área de obras de infraestrutura viária. 


\section{MÉTODO}

Em uma visão mais ampla, procurou-se realizar, neste capítulo, a identificação de aspectos que se apresentam como relevantes na análise da relação das características do projeto geométrico com o número de acidentes. O primeiro passo da avaliação é realizado a partir do conhecimento geral das características que podem ser elementos-chave para a potencialização dos acidentes e dos programas que podem ser utilizados para realizar tal estudo. Este foi o propósito da abordagem geral e das características e das potencialidades de cada elemento mostrados no capítulo 2 desta dissertação.

Para uma avaliação minuciosa de como os elementos se relacionam com a potencialização dos acidentes seria necessário um estudo mais complexo tentando relacionar cada característica com a causa dos acidentes. Para um propósito de simplificação, o objetivo deste estudo foi unicamente a consistência da rodovia. Foram retiradas para triagem duas ferramentas para análise: IHSDM e Saepro.

No entanto, Garcia (2008) não recomenda a utilização do software IHSDM para as rodovias brasileiras, uma vez que o modelo está calibrado para as condicionantes culturais do condutor, de veículo e das vias americanas, mas propõe um modelo para a análise da consistência geométrica de rodovias brasileiras em pistas simples através de modelos de estimativa da velocidade operacional e de critérios classificatórios de trechos utilizado na ferramenta Saepro.

Tendo em vista do que foi exposto, para a realização deste trabalho foi desenvolvida uma série de atividades com a finalidade de direcionar o estudo para alcançar o objetivo do trabalho. Estas atividades são descritas de forma resumida:

a) Análise, apresentação e descrição de todas as características que podem potencializar os acidentes e das ferramentas de análise mais utilizadas;

b) Levantamento e seleção das rodovias para estudo de caso, considerando, principalmente, as características técnicas de alinhamento e os números de acidentes;

c) Estudo e análise do efeito da consistência do projeto geométrico das rodovias selecionadas por meio do programa Saepro; 
d) Coleta e tratamento dos dados de acidentes de trânsito registrados na rodovia em estudo, obtidos junto a órgão competente, de modo a compor um banco de dados;

e) Correlação das estatísticas de acidentes na rodovia com o estudo da consistência da via.

\subsection{CARACTERÍSTICAS DAS VIAS E A RELAÇÃo COM OS ACIDENTES}

Inicialmente foi realizado um estudo para obter os fatores que poderiam ser considerados. Foi realizada uma extensa pesquisa bibliográfica mostrando que acidentes são eventos de natureza complexa para os quais podem contribuir de maneira simultânea diversos fatores associados aos componentes humano, viário-ambiental e veicular. Também foram apresentados resultados de pesquisas recentes que mostraram alguns efeitos específicos das características físico-operacionais da infraestrutura viária na segurança.

\subsection{SELEÇÃO DA RODOVIA PARA ESTUdO DE CASO}

A Avenida Menezes Cortes, conhecida também como Autoestrada Grajaú-Jacarepaguá, foi escolhida devido ao grande número de acidentes com vítimas que lá ocorrem. Segundo SMTR (2012), a via é a nona colocada num ranking dos logradouros de toda a cidade do Rio de Janeiro.

Tabela 5.1: Ranking dos logradouros com maior número absoluto de acidentes com vítimas no ano de 2012 até junho no município do Rio de Janeiro

\begin{tabular}{c|ccccc}
\hline Logradouros & Atropelamentos & $\begin{array}{c}\text { Capotamentos } \\
\text { com vítimas }\end{array}$ & $\begin{array}{c}\text { Colisóes } \\
\text { com } \\
\text { vítimas }\end{array}$ & $\begin{array}{c}\text { Tombamentos } \\
\text { com vítimas }\end{array}$ & $\begin{array}{c}\text { Total de } \\
\text { acidentes } \\
\text { com } \\
\text { vítimas }\end{array}$ \\
\hline $\begin{array}{c}\text { Avenida das Américas } \\
\text { Avenida Dom Hélder }\end{array}$ & 88 & 31 & 336 & 40 & 495 \\
$\begin{array}{c}\text { Câmara } \\
\text { Avenida Presidente } \\
\text { Vargas }\end{array}$ & 67 & 1 & 106 & 7 & 181 \\
$\begin{array}{c}\text { Estrada dos } \\
\text { Bandeirantes }\end{array}$ & 41 & 2 & 93 & 20 & 181 \\
$\begin{array}{c}\text { Avenida Ayrton Senna } \\
\text { Avenida Pastor Martin }\end{array}$ & 25 & 2 & 103 & 7 & 153 \\
$\begin{array}{c}\text { Luther King } \\
\text { Avenida de Santa Cruz } \\
\text { Avenida Cesário de } \\
\text { Melo }\end{array}$ & 29 & 15 & 87 & 20 & 147 \\
$\begin{array}{c}\text { Avenida Menezes } \\
\text { Cortes }\end{array}$ & 39 & 4 & 95 & 13 & 141 \\
Avenida Lucio Costa & 19 & 3 & 84 & 14 & 140 \\
\hline
\end{tabular}

Fonte: SMTR (2012). 
Outro fator que ajudou a escolha dessa via foi a disponibilização por parte da Companhia de Engenharia de Tráfego do Rio de Janeiro (CET-Rio) de um mapa com os dados de pontos críticos dos acidentes da Autoestrada Grajaú-Jacarepaguá (Figura 5.1).

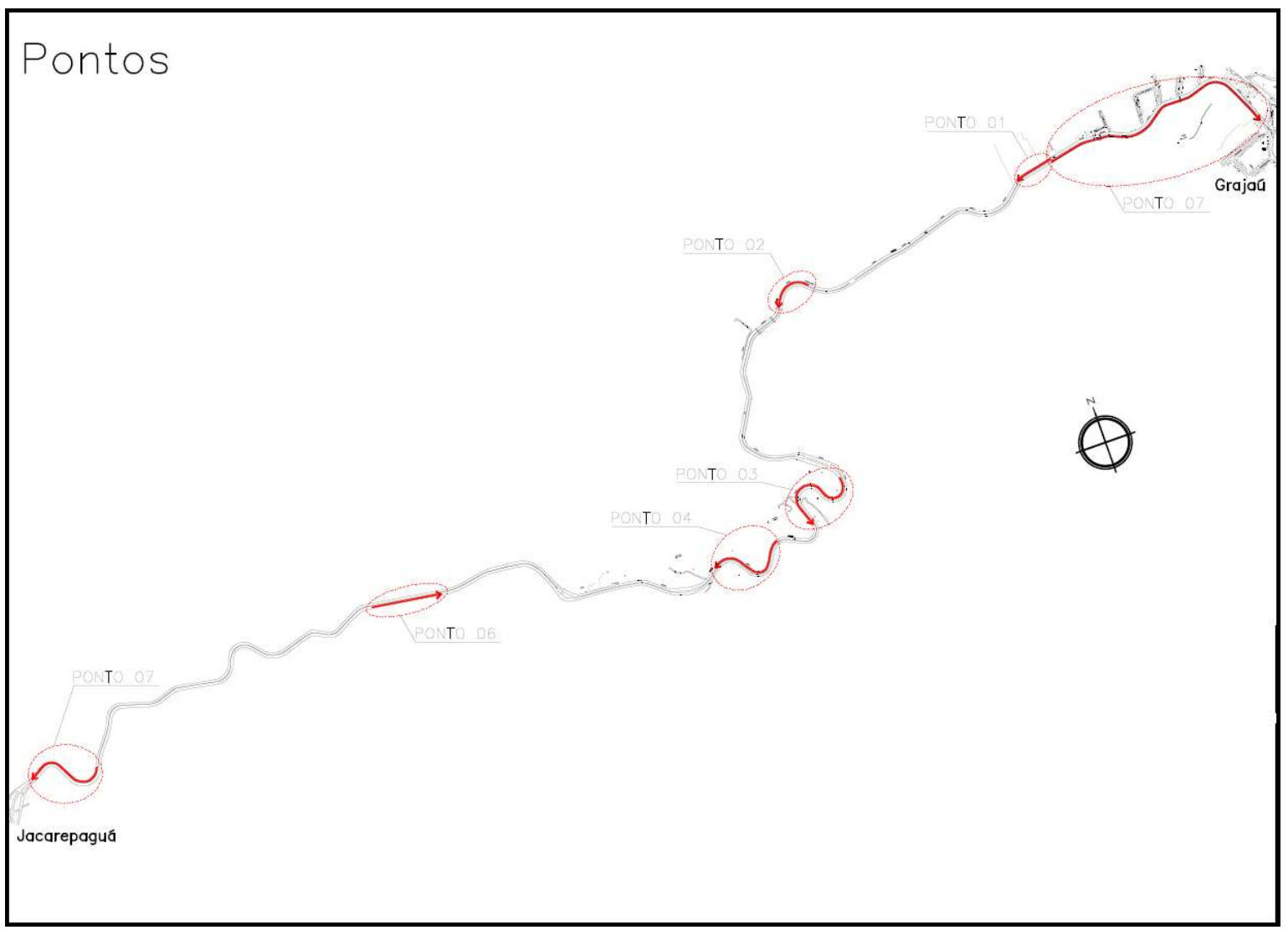

Figura 5.1: Pontos críticos dos acidentes da Avenida Menezes Cortes. Fonte: CET-Rio (2012).

\subsection{ESTUDO DAS CARACTERÍSTICAS DA VIA}

Foi realizada uma caracterização minuciosa da Avenida Menezes Cortes, para se ter uma compreensão da ocorrência dos acidentes. A caracterização da via abordou basicamente em três aspectos: a caracterização de seu entorno, do tráfego e do projeto e as condições de sua infraestrutura.

\subsection{COLETA E TRATAMENTO DOS DADOS DE ACIDENTES DE TRÂNSITO}

A coleta dos dados de acidentes de trânsito registrados na Avenida Menezes Cortes, na cidade do Rio de Janeiro, referente aos anos de 2011 a 2015, foi feita junto à Companhia de Engenharia de Tráfego do Rio de Janeiro (CET-Rio). Os dados de acidentes de trânsito foram tratados em uma planilha eletrônica que compreendeu a uniformização de dados e a identificação de possíveis inconsistências. 
5.5. RELAÇÃo dos ACIDENTES NA RODOVIA COM O ESTUdo DAS CARACTERÍSTICAS

A relação dos acidentes da via com o estudo das características foi feita por várias análises, alguns em cima das bases estatísticas fornecidas pela CET-Rio, outras com base nas visualizações de movimentos que os motoristas fazem na avenida ou até mesmo em cima de conversas com os bombeiros que realizam salvamentos na região, buscando sempre uma relação com as características das vias. 


\section{ESTUDO DE CASO: AVENIDA MENEZES CORTES}

Segundo Brigido (1950), a Autoestrada Grajaú-Jacarepaguá começou a ser construída em 1945 por iniciativa da Prefeitura e do Departamento Nacional de Estradas de Rodagem. É oficialmente denominada como Avenida Menezes Cortes. Devido a interrupções da obra de natureza econômico-administrativa, apenas em 1948, na administração do General Ângelo Mendes de Moraes, os serviços foram entregues por concorrência pública à Companhia Serviços de Engenharia. A obra teve sua conclusão em 1950. A Figura 6.1 (a) e a Figura 6.1 (b) mostram a Avenida na época de sua construção.
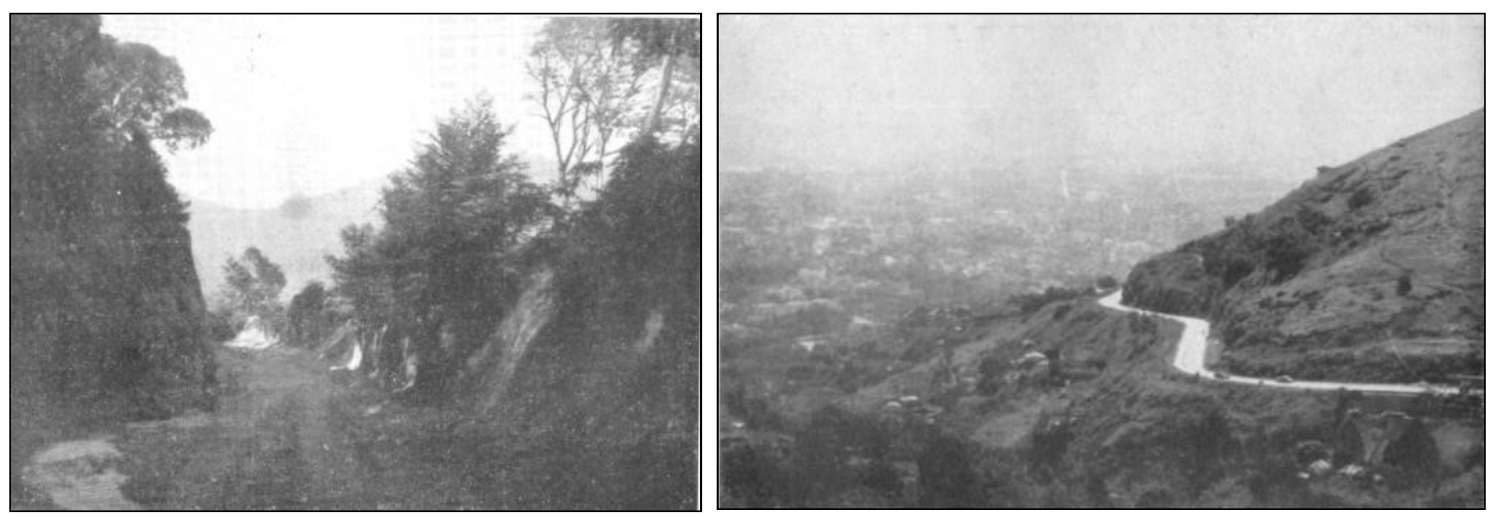

Figura 6.1: (a) Seção transversal da Estrada Grajaú-Jacarepaguá (esquerda) e (b) vista de parte de seu traçado (direita) na época de sua construção.

Fonte: Foi um Rio que passou (2005).

Era de grande necessidade a ligação direta entre o Centro da capital da República e a região de Jacarepaguá, uma vez que facilitaria o escoamento da produção agrícola cultivada na localidade que se estendia desde o Pau Ferro ao Grumari e aos Bandeirantes e da praia do Pontal ao Cafundá e ao Catonho.

Ao se considerar um ponto central da cidade e um ponto de concentração das atividades em Jacarepaguá, a construção da estrada Grajaú-Jacarepaguá proporcionou um sensível encurtamento de trajeto relativo a outros dois trechos de menor percurso mais utilizados na época, como pode ser visto na Tabela 6.1.

Entre as várias dificuldades que afetaram a execução de sua obra, duas podem ser classificadas de caráter singular: a que decorre no grande número de desapropriações e demolições, retardando a implantação do projeto no campo e a abertura da caixa da estrada, e a que provém da natureza da encosta por onde se desenvolve o traçado. 
Tabela 6.1: Distâncias entre Jacarepaguá e Centro do Rio de Janeiro em 1950

\begin{tabular}{|c|c|}
\hline Ligação Centro-Jacarepaguá & Distância \\
\hline Via Alto da Boa Vista & $35 \mathrm{~km}$ \\
\hline Via Largo do Campinho & $30 \mathrm{~km}$ \\
\hline Via Grajaú & $22 \mathrm{~km}$ \\
\hline
\end{tabular}

Fonte: Brigido (1950).

Como providências a tais problemas, na sua maioria, emergenciais, foram realizadas obras de segurança e de proteção da placa, assim como grandes muralhas de sustentação, obras especiais de drenagem, contenção das saias de aterro e dos taludes de corte.

No final dos anos 1970, a velha estrada já demonstrava sinais de saturação, provinda da falta de opções de escoamento da baixada de Jacarepaguá, tanto em população, como em produtos industriais e de serviços com a consolidação do polo industrial da Estrada dos Bandeirantes. Sendo assim, seria necessário colocar em prática um projeto dos anos 1960 de aumentar a capacidade da estrada.
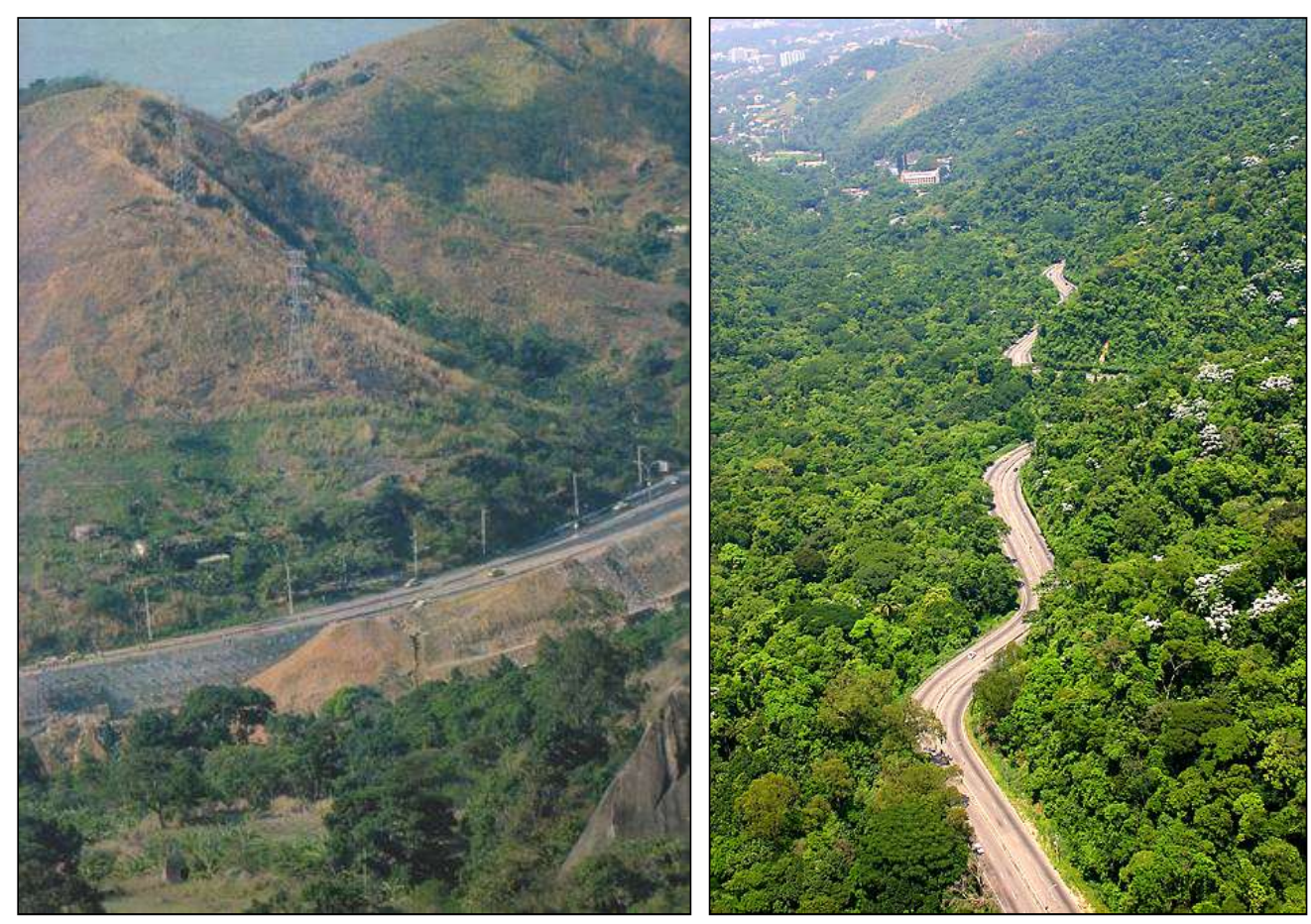

Figura 6.2: (a) Vista da Estrada Grajaú-Jacarepaguá (esquerda) e (b) vista de parte de seu traçado (direita) após a obra de duplicação.

Fonte: Foi um Rio que passou (2005) e Rio (2011). 
As obras de duplicação foram entregues em 1981, no trecho de Jacarepaguá, e o trecho do Grajaú entregue no final de 1982 devido à divisão da obra em três etapas, em função de sua complexidade. A Figura 6.2 (a) e Figura 6.2 (b) mostram a Avenida após a sua duplicação.

\subsection{LOCALIZAÇÃO DA VIA}

Pertencendo ao sistema viário de trânsito rápido da cidade do Rio de Janeiro, a Autoestrada Grajaú-Jacarepaguá possui cerca de 7,5 km de extensão nos dois sentidos. Com uma orientação leste-oeste, a via liga o bairro do Grajaú, na Zona Norte, ao bairro de Jacarepaguá, na Zona Oeste da cidade. Na Figura 6.3 pode-se visualizar o traçado da Avenida Menezes Cortes.
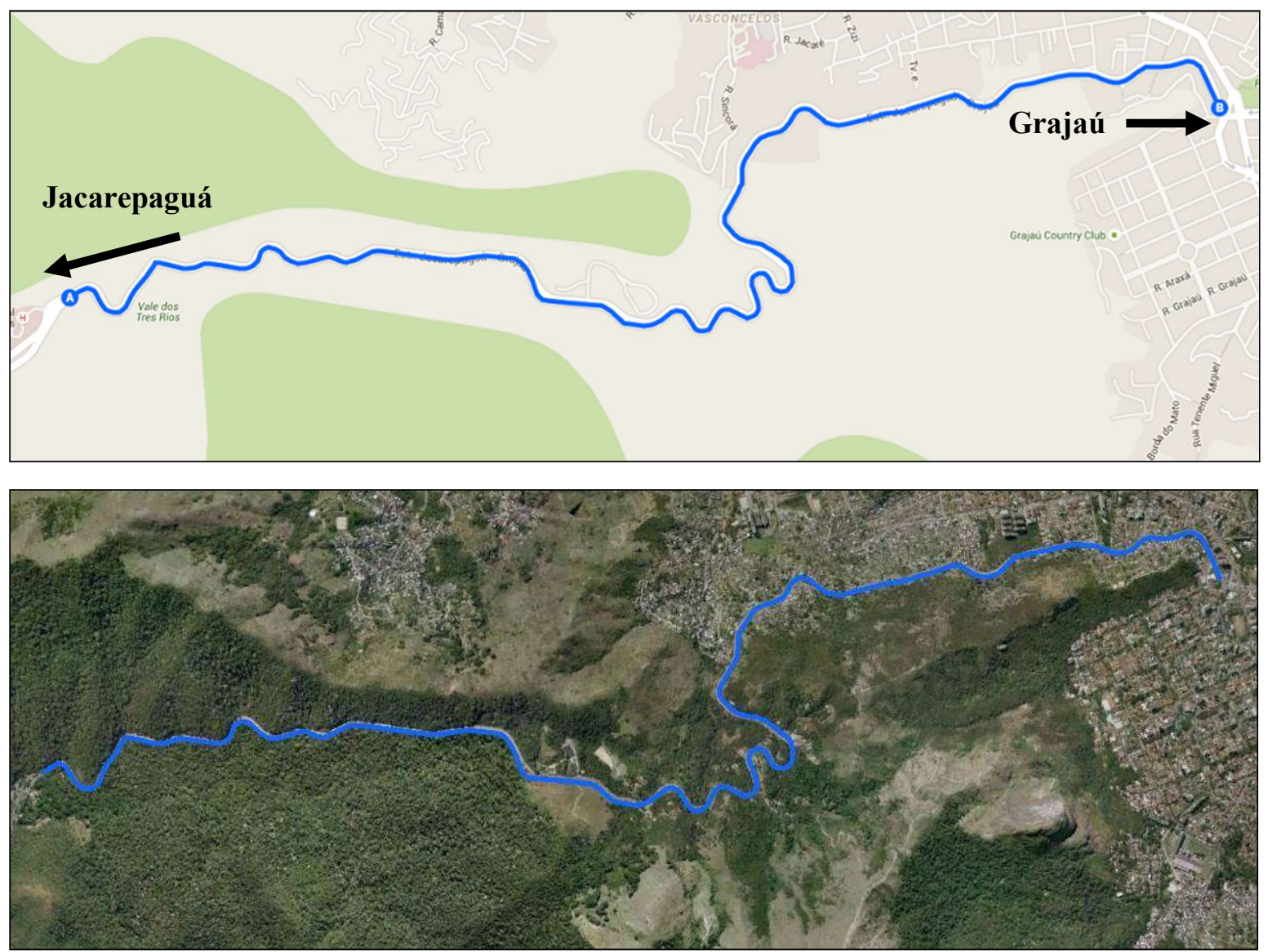

Figura 6.3: Traçado da Avenida Menezes Cortes.

Fonte: Adaptado do Google Maps (2015). 


\subsection{CARACTERIZAÇÃo do ENTORNO}

O entorno da Autoestrada Grajaú-Jacarepaguá é caracterizado por duas divisões bem distintas: uma com forte urbanização e grande densidade demográfica e a outra despovoada caracterizada pela formação da Mata Atlântica, no Parque Nacional da Tijuca (Figura 6.4). A via passa pelos seguintes bairros: Grajaú, Lins de Vasconcelos, Engenho de Dentro, Água Santa e Jacarepaguá.

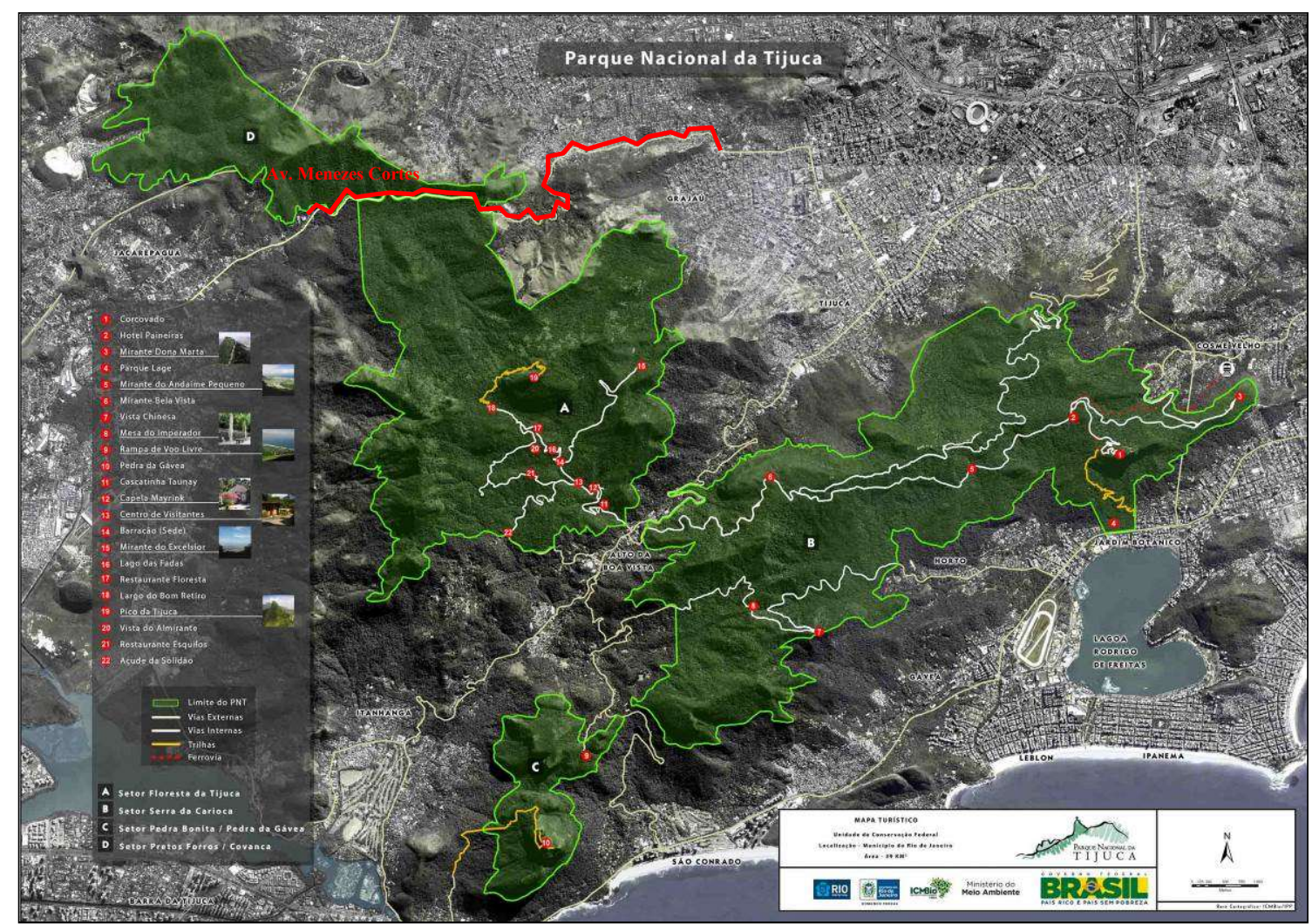

Figura 6.4: Mapa do Parque Nacional da Tijuca e localização da Avenida Menezes Cortes. Fonte: Adaptado de Parque Nacional da Tijuca (2011).

Analisando em ambos os sentidos, a via contém apenas duas saídas e dois acessos ao todo, localizados em suas extremidades. Dessa forma, a Avenida possui acessos e saídas, no Grajaú, com a rua José do Patrocínio e a rua Visconde de Santa Isabel (Figura 6.5 e Figura 6.6) e, em Jacarepaguá, com a Estrada dos Três Rios e a Estrada Santa Inês (Figura 6.7 e Figura 6.8). 


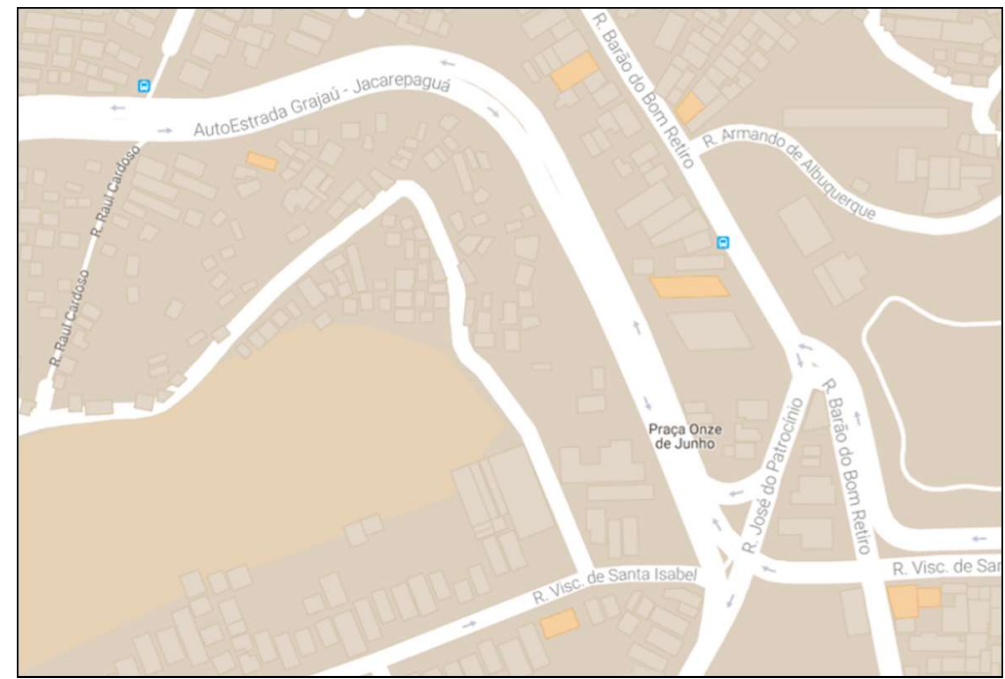

Figura 6.5: Mapa do acesso e da saída da Avenida Menezes Cortes no bairro do Grajaú. Fonte: Google Maps (2015).
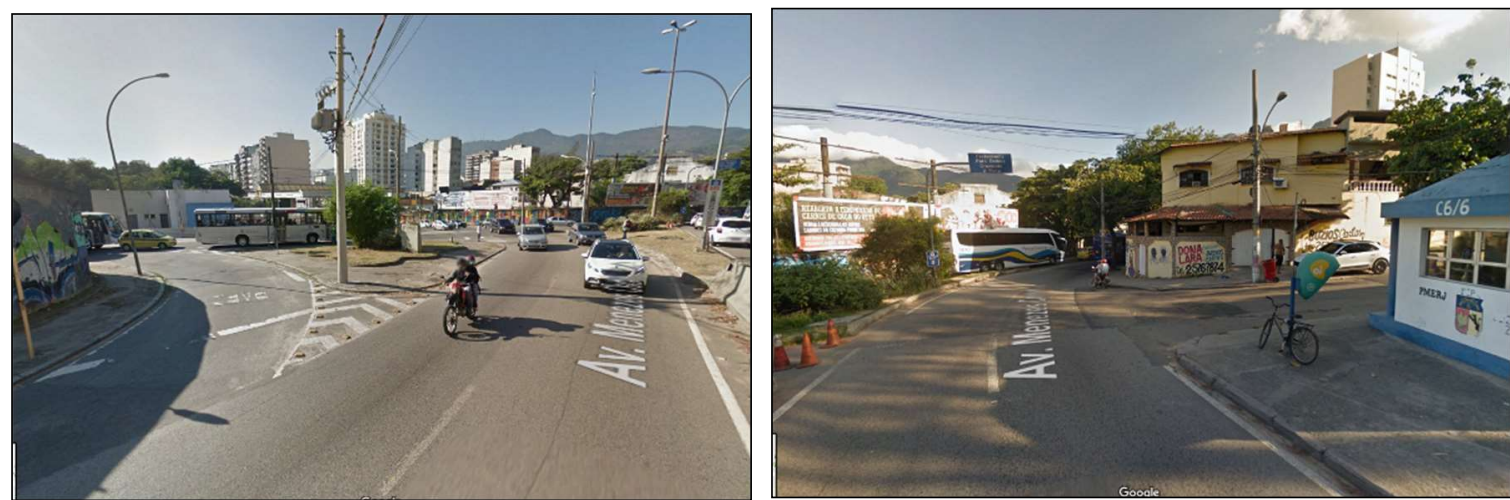

Figura 6.6: Fotos do acesso e da saída da Avenida Menezes Cortes no bairro do Grajaú. Fonte: Google Maps (2015).

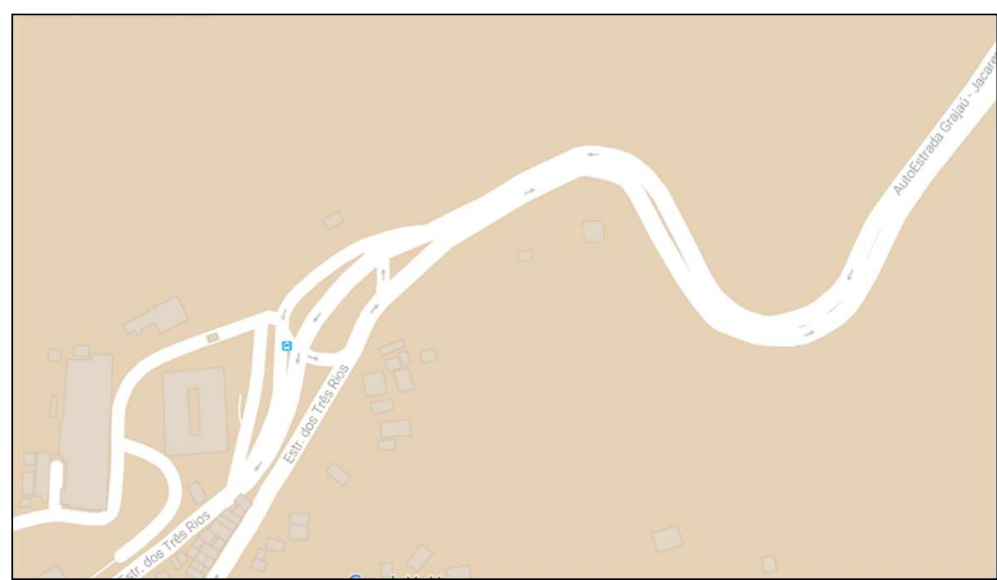

Figura 6.7: Acesso e saída da Avenida Menezes Cortes no Bairro de Jacarepaguá. Fonte: Google Maps (2015). 

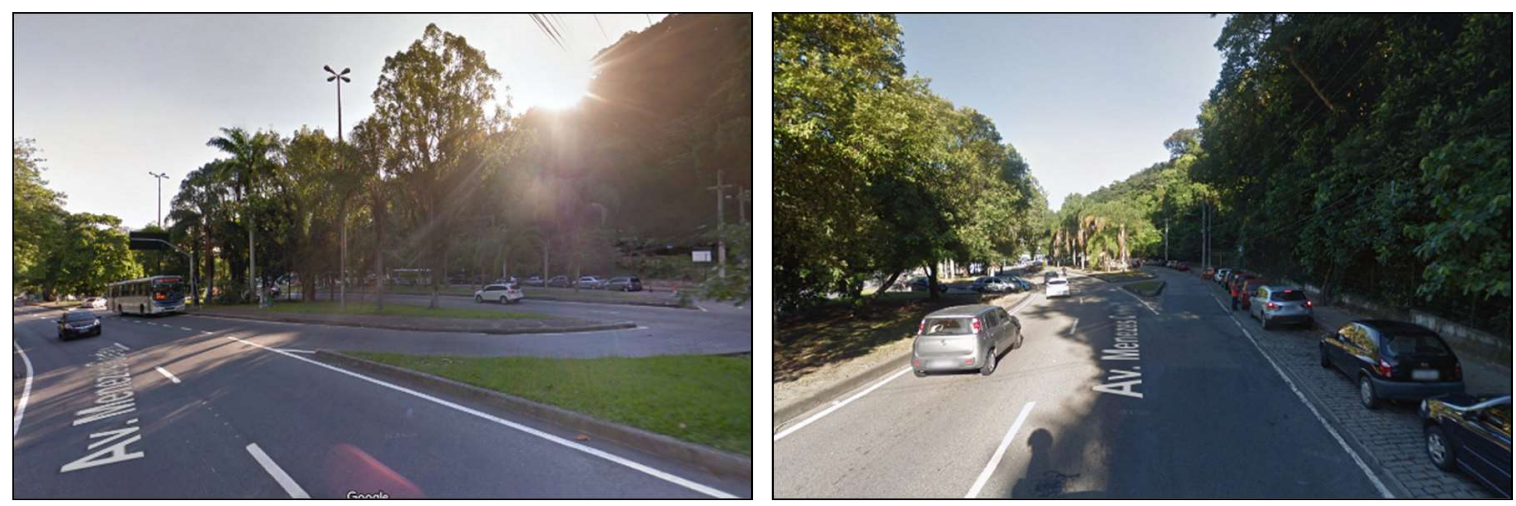

Figura 6.8: Acesso e saída da Avenida Menezes Cortes no bairro de Jacarepaguá. Fonte: Google Maps (2015).

\subsection{CARACTERIZAÇÃo do TRÁFEgo}

Pela Autoestrada Grajaú-Jacarepaguá circula um volume de tráfego bastante intenso. De acordo com os dados do Plano Diretor de Transporte Urbano 2011 (PDTU) do Rio de Janeiro divulgado em 2013, o Volume Médio Diário de Tráfego (AADT), na saída para a rua José do Patrocínio, foi de 37.502 veículos, sendo a grande maioria deles de carros e veículos leves, como pode ser visto na Tabela 6.2.

Tabela 6.2: Contagens de veículos por categoria

\begin{tabular}{c|c}
\hline Posto & $\begin{array}{c}\text { Avenida Menezes Cortes } \boldsymbol{x} \\
\text { José do Patrocínio }\end{array}$ \\
\hline Autos & 28.793 \\
Táxi & 2.715 \\
Escolar & 13 \\
Moto & 2.574 \\
Bicicleta & 17 \\
Ônibus & 1.426 \\
Van T Ater & 280 \\
Kombi T Alter & 0 \\
Caminhao 2 eixos & 553 \\
Caminhão 3 ou mais & 62 \\
eixos & 1.069 \\
Utilitário & 37.502 \\
Total
\end{tabular}

Fonte: PDTU (2013).

Apesar de ser uma via destinada a um trânsito rápido de veículos, ocorrem por muitas vezes condições operacionais difíceis, com tráfego lento, paradas e congestionamentos devido ao elevado volume de veículos. 
A Avenida Menezes Cortes também serve como um importante corredor de transporte público da cidade. Um considerável volume de ônibus circula pela via em 10 linhas que ligam Jacarepaguá (Tabela 6.3) e os outros bairros adjacentes com o Centro e com os bairros da Zona Norte. Devido a presença do sistema de transporte público por ônibus, a via apresenta 26 pontos de parada de ônibus (Figura 6.9).

Tabela 6.3: Relação de linhas que percorrem a Avenida Menezes Cortes

\begin{tabular}{c|c}
\hline Linha & Vista \\
\hline 306 & Praça Seca - Castelo (via Avenida Menezes Cortes) \\
341 & Taquara - Candelária \\
368 & Rio Centro - Candelária \\
390 & Curicica - Candelária (via Estrada do Guerenguê) \\
600 & Taquara - Saens Peña (via Cidade de Deus/Avenida Menezes \\
& Cortes) \\
601 & Taquara - Saens Peña (via Avenida Menezes Cortes) \\
2110 & Gardênia Azul - Castelo \\
2111 & Praça Seca - Castelo (via Avenida Menezes Cortes) \\
2114 & Freguesia - Castelo \\
LECD 22 & Cidade de Deus - Candelária (via Avenida Menezes Cortes) \\
\hline \multicolumn{2}{c}{ Fonte: Vá de Ônibus (2016). }
\end{tabular}

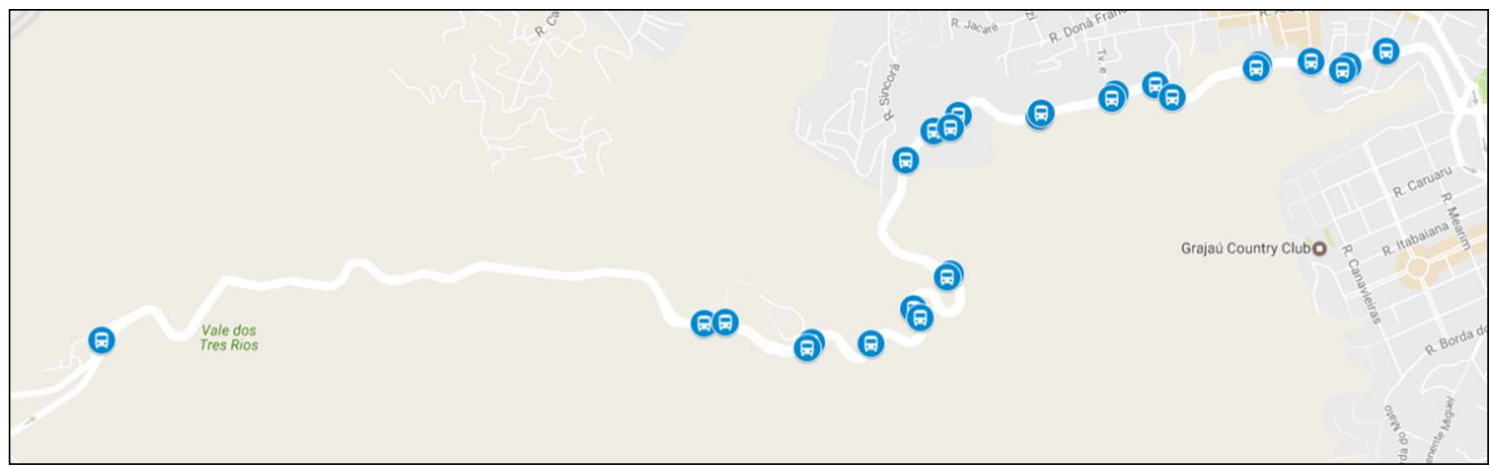

Figura 6.9: Localização dos pontos de embarque e desembarque da Avenida Menezes Cortes.

No que tange a circulação de pedestres, três passarelas garantem a travessia dos usuários em condições adequadas de segurança (Figura 6.10 e Figura 6.11). Entretanto, a presença de pessoas na pista é comum devido à presença de habitações e comércios irregulares nas duas margens da via. 


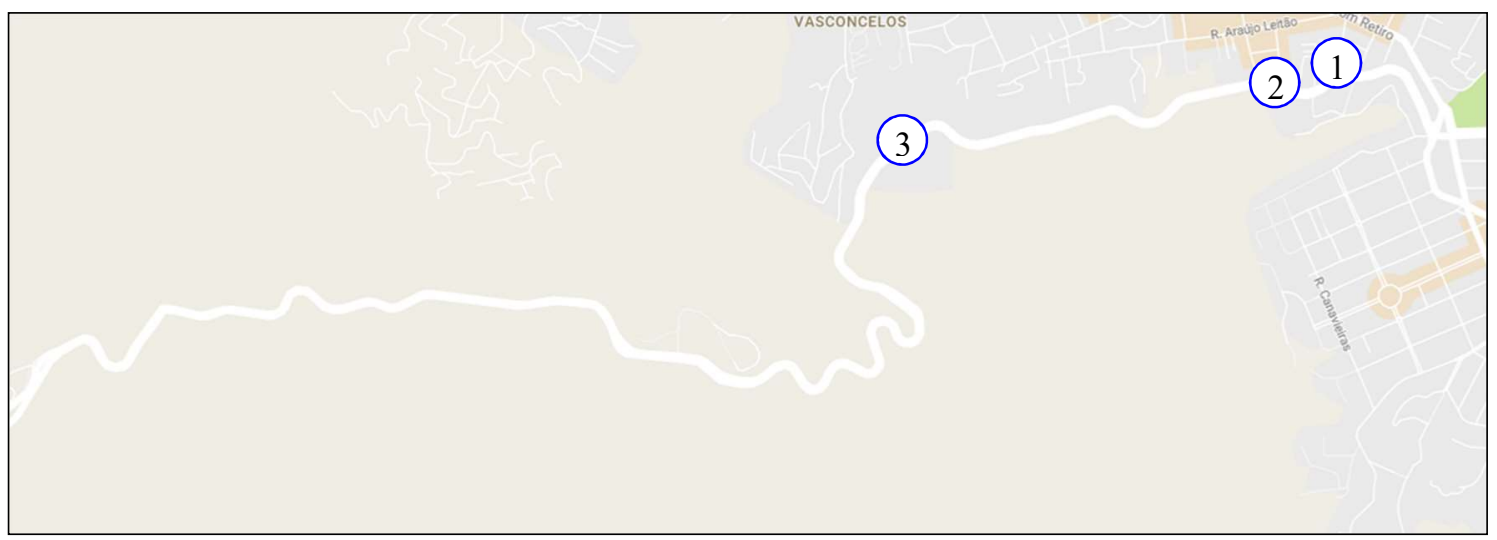

Figura 6.10: Localização das passarelas da Avenida Menezes Cortes.
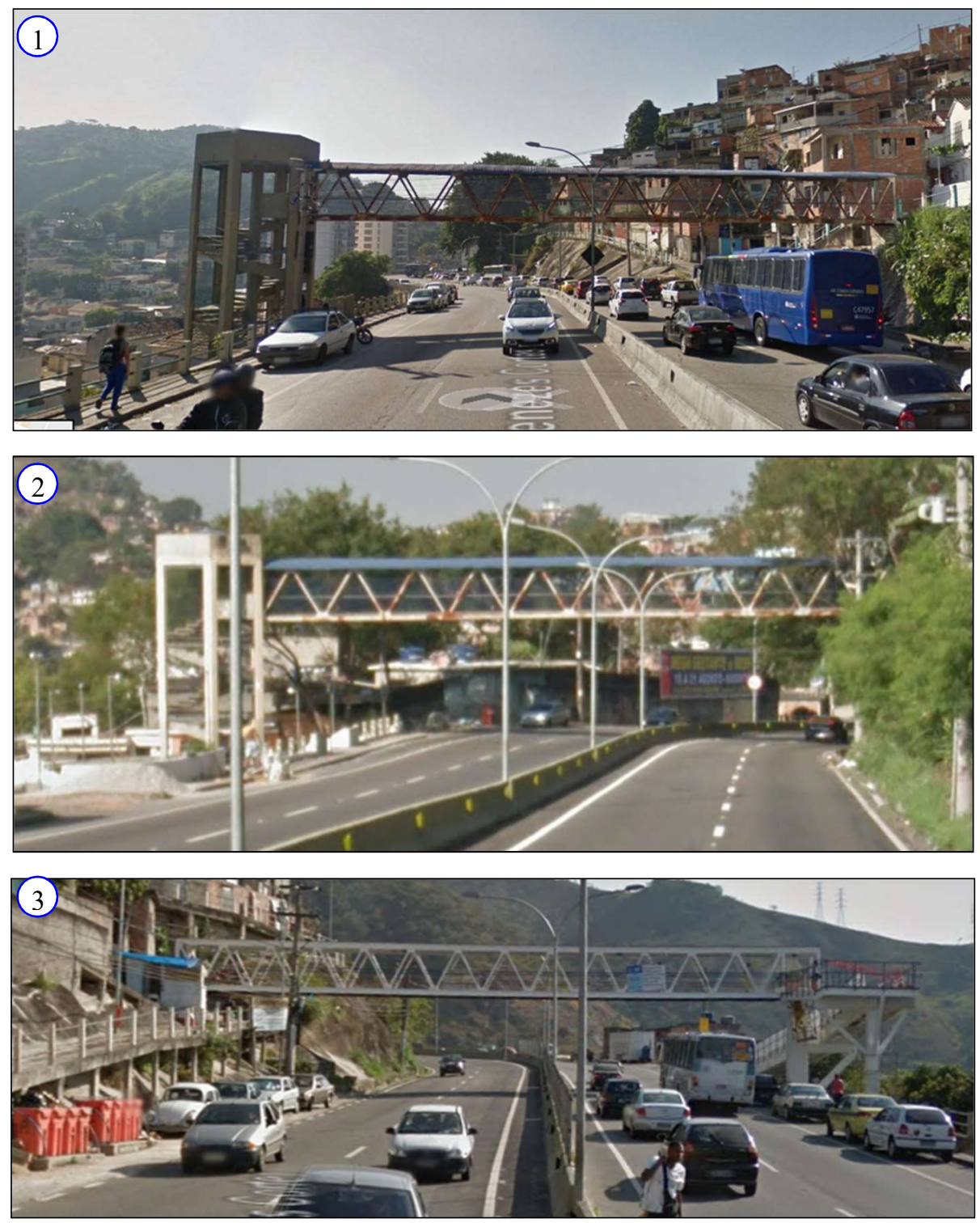

Figura 6.11: Fotos das passarelas da Avenida Menezes Cortes. Fonte: Google Maps (2015). 


\subsection{CARACTERIZAÇÃo do PROJETO}

Para a coleta dos dados de alinhamento horizontal e vertical do projeto geométrico foi realizada uma investigação da topografia da região e foi levantado o projeto geométrico de acordo com a visualização do traçado em planta no AutoCAD Civil 3D. As curvas horizontais foram todas tratadas como simples para uma simplificação. Além disso, foram utilizados os dados sobre os acidentes fornecidos pela CET-Rio e os resultados de uma préanálise de sete pontos críticos que foram julgados pela empresa problemáticos para a segurança da via.

Na maior parte de sua extensão, a Autoestrada Grajaú Jacarepaguá apresenta uma seção transversal típica formada por duas faixas de circulação por sentido com barreira central de concreto em quase toda a sua extensão e barreiras longitudinais de contenção de diferentes tipos (Figura 6.12, Figura 6.13, Figura 6.14 e Figura 6.15).

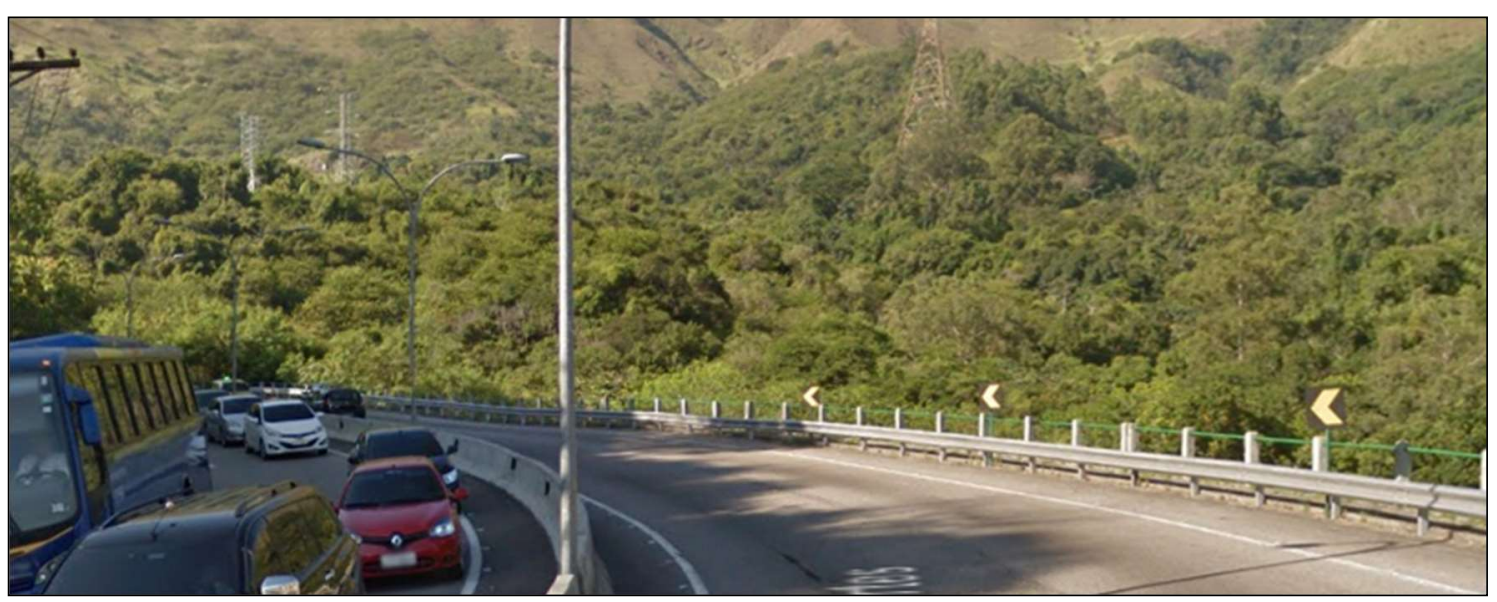

Figura 6.12: Seção transversal com dois tipos de barreiras de contenção.

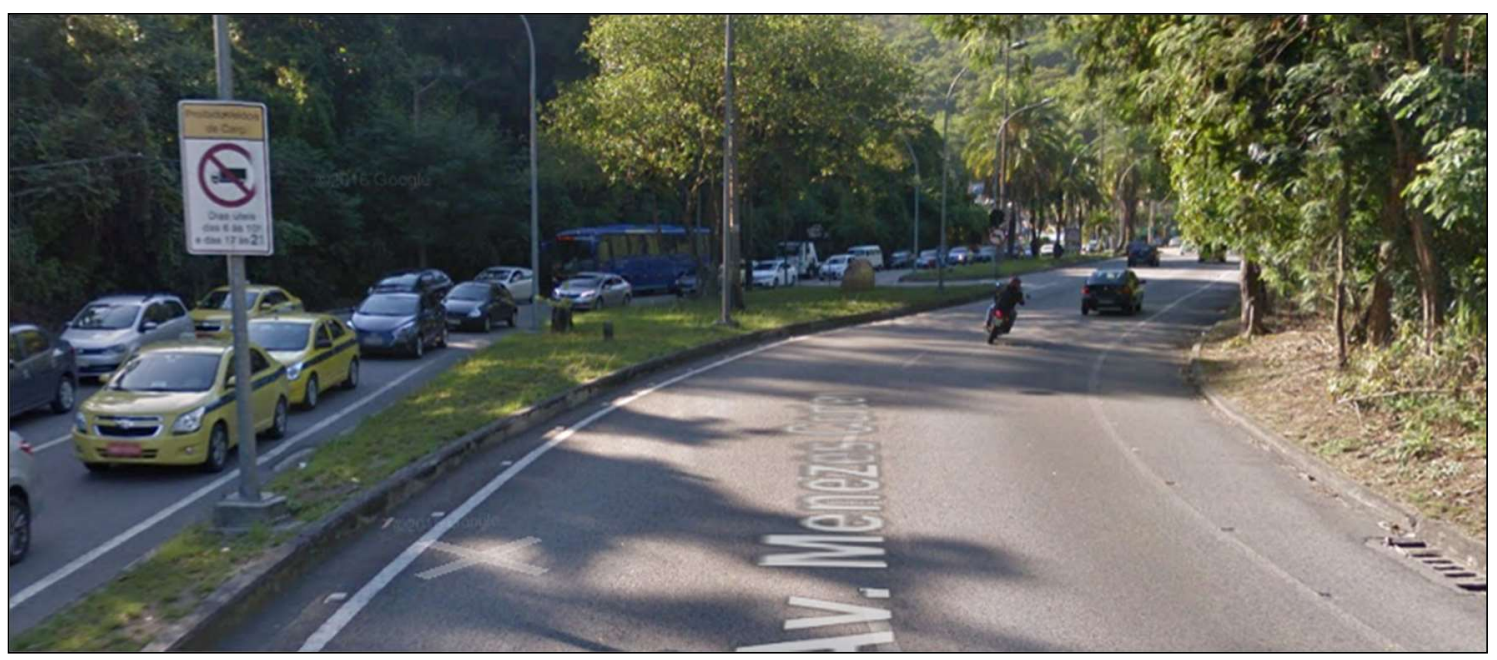

Figura 6.13: Seção transversal com canteiro central gramado. 


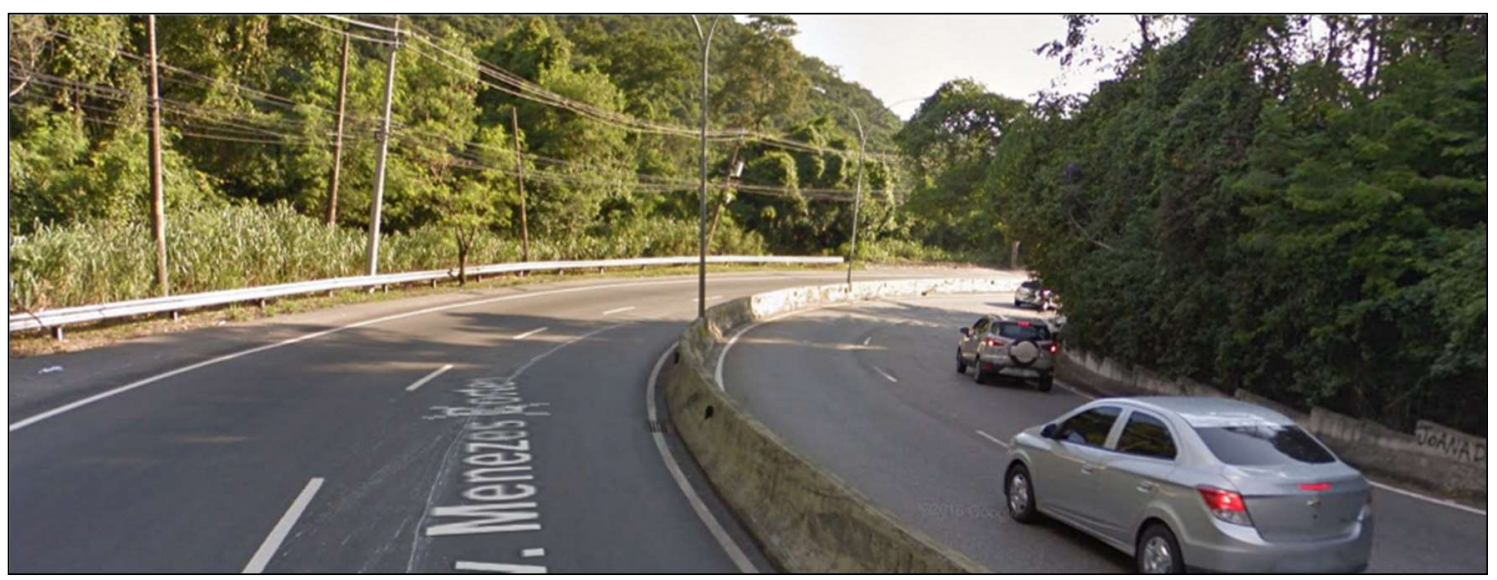

Figura 6.14: Seção transversal com guard rail metálico e barreira de contenção de concreto.

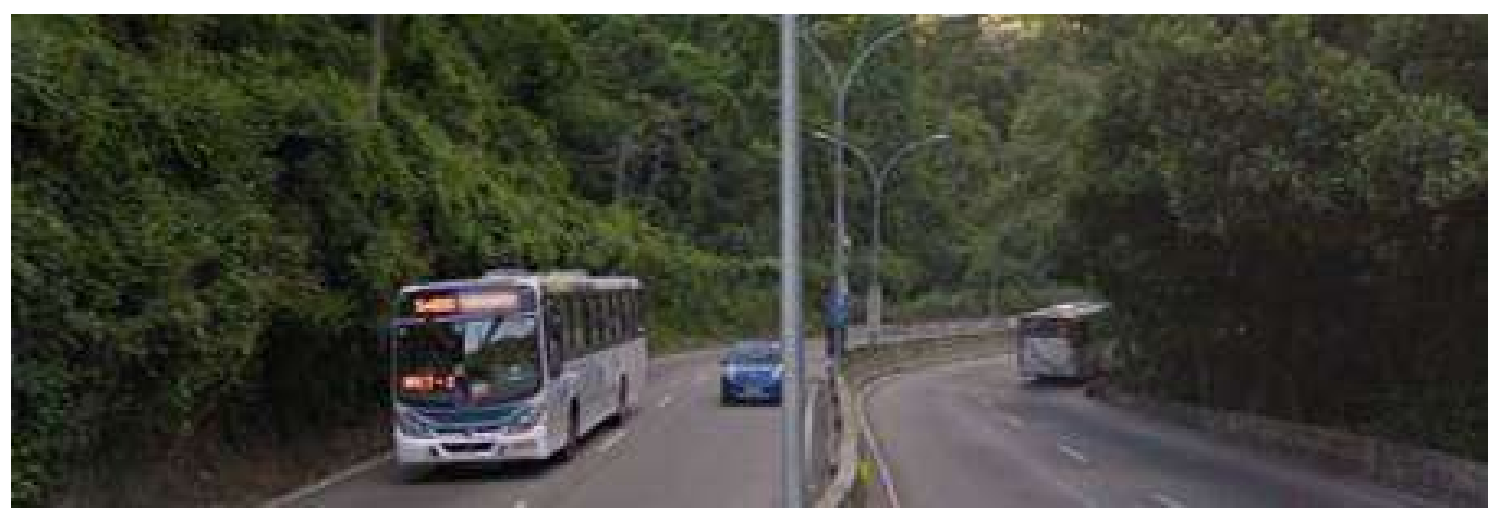

Figura 6.15: Seção transversal com barreira de contenção de concreto.

Passando principalmente por terreno ondulado/montanhoso, o traçado da via é caracterizado pela presença de curvas horizontais acentuadas e a presença de aclives e declives pronunciados. Dentro do trecho especificado, foram identificadas 50 curvas horizontais apresentadas na Tabela 6.4 e estas estão identificadas na Figura 6.16: 
Tabela 6.4: Tabela de curvas da Avenida Menezes Cortes

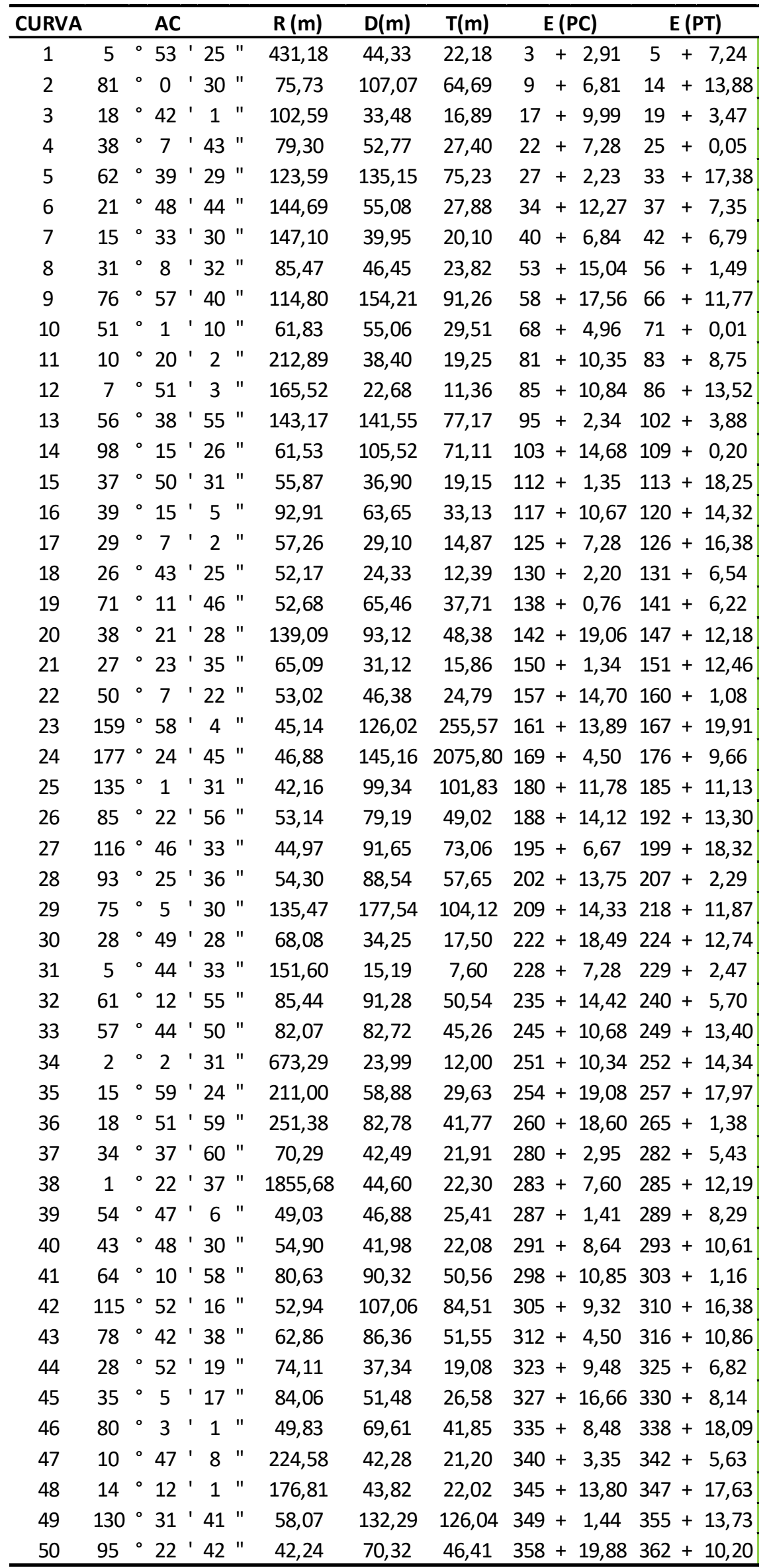



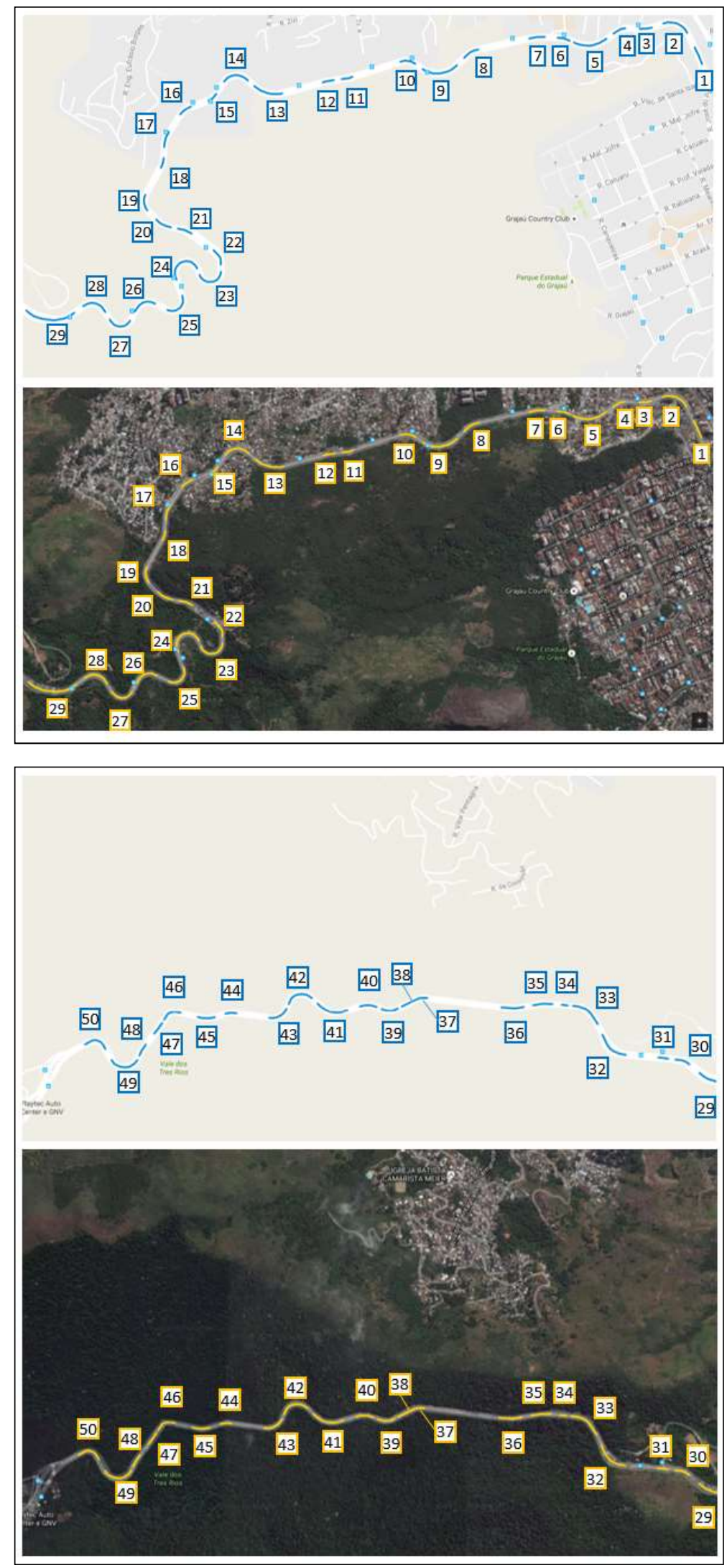

Figura 6.16: Mapa esquemático com as curvas da Avenida Menezes Cortes. 


\subsection{CONDIÇÕES DA INFRAESTRUTURA}

Durante uma inspeção preliminar realizada na Autoestrada Grajaú-Jacarepaguá foi possível verificar as condições gerais dos elementos mais importantes da infraestrutura viária. Foram constatados, sobretudo, aspectos associados à geometria da via, ao pavimento, à sinalização, às interseções e aos dispositivos de drenagem.

A via apresenta um traçado sinuoso, bem acidentado e com curvas fechadas, que junto a uma largura de faixas inadequada e a uma barreira de concreto central proporciona uma limitação de comodidade e segurança ao circular a velocidade regulamentada na via. Caracteriza-se também por possuir aclives bem acentuados, o que faz com que veículos mais pesados percam potência e, consequentemente, velocidade nas subidas.

Quanto ao pavimento, a via se caracteriza por ter dois trechos bem distintos: um trecho em más condições, com buracos, fissuras e desníveis (Figura 6.17) e outro com excelentes condições, revestimento constituído por uma mistura especial do tipo SMA (Stone Matrix Asphalt) com asfalto modificado por borracha, sem buracos, trincas ou desníveis notáveis (Figura 6.18).

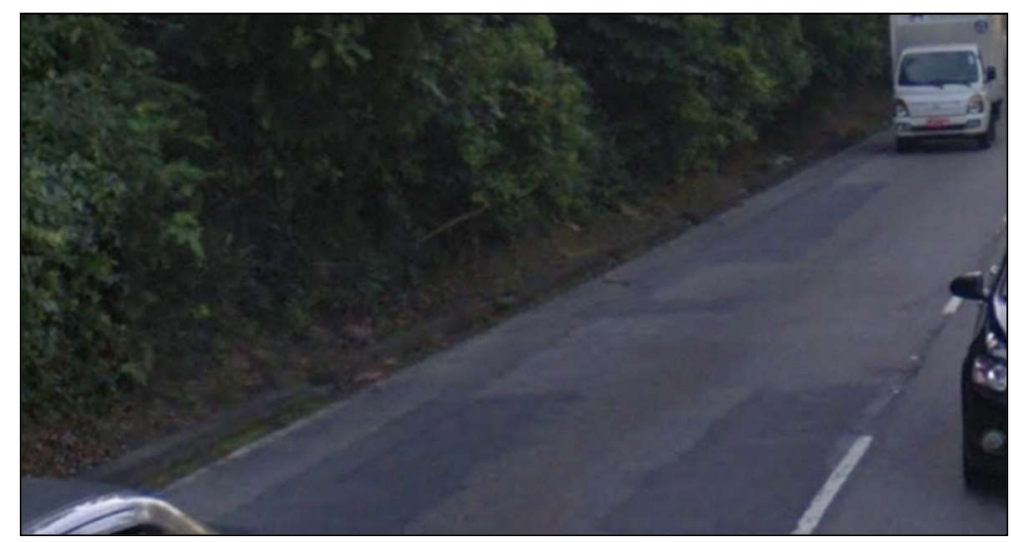

Figura 6.17: Trecho sem SMA (Stone Matrix Asphalt).

A sinalização da via também se apresenta bem aquém do desejado. Algumas sinalizações do pavimento e as placas apresentam condições distintas em alguns trechos da via. Determinadas placas exibem marcas de vandalismo e perderam sua principal função de advertência. 


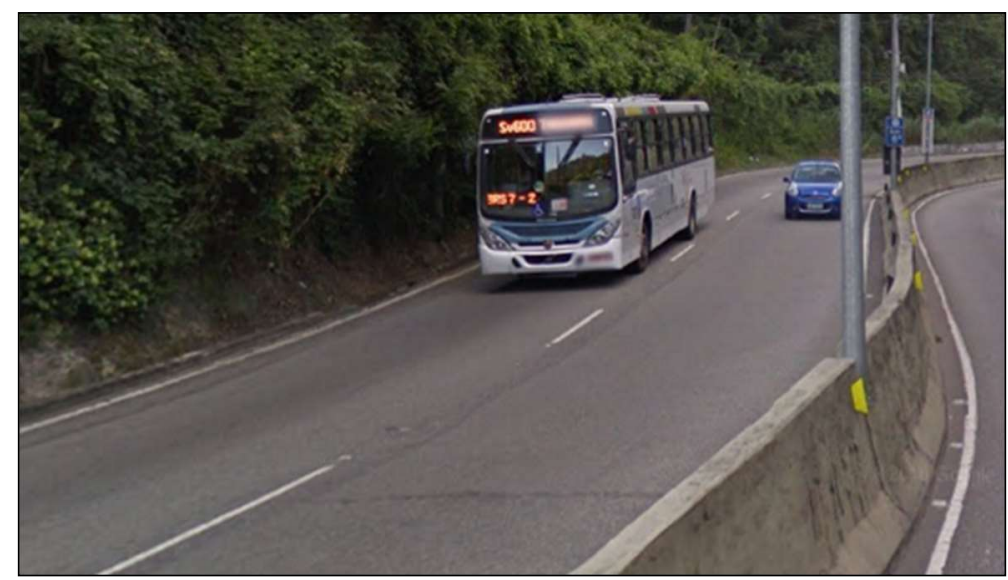

Figura 6.18: Trecho com SMA (Stone Matrix Asphalt).

Os acessos em nível apresentam-se bem sinalizados nos seus extremos, porém devido à grande densidade populacional na região do Grajaú, algumas ruas se apresentam escondidas e de difícil localização. Outro fator que foi analisado é a questão dos retornos da via, em específico o da imediação do Hospital Cardoso Fontes, que não apresenta qualquer indício de sinalização.

Quanto à drenagem, a via apresenta em alguns pontos a água pluvial coletada pelas sarjetas e valetas passando transversalmente à superfície do pavimento. Em um desses pontos, também se encontra um lava a jato que se utiliza de tais dispositivos para o despejo de água com sabão, contribuindo assim com o aumento no número de acidentes nesse ponto (Figura $6.19)$.

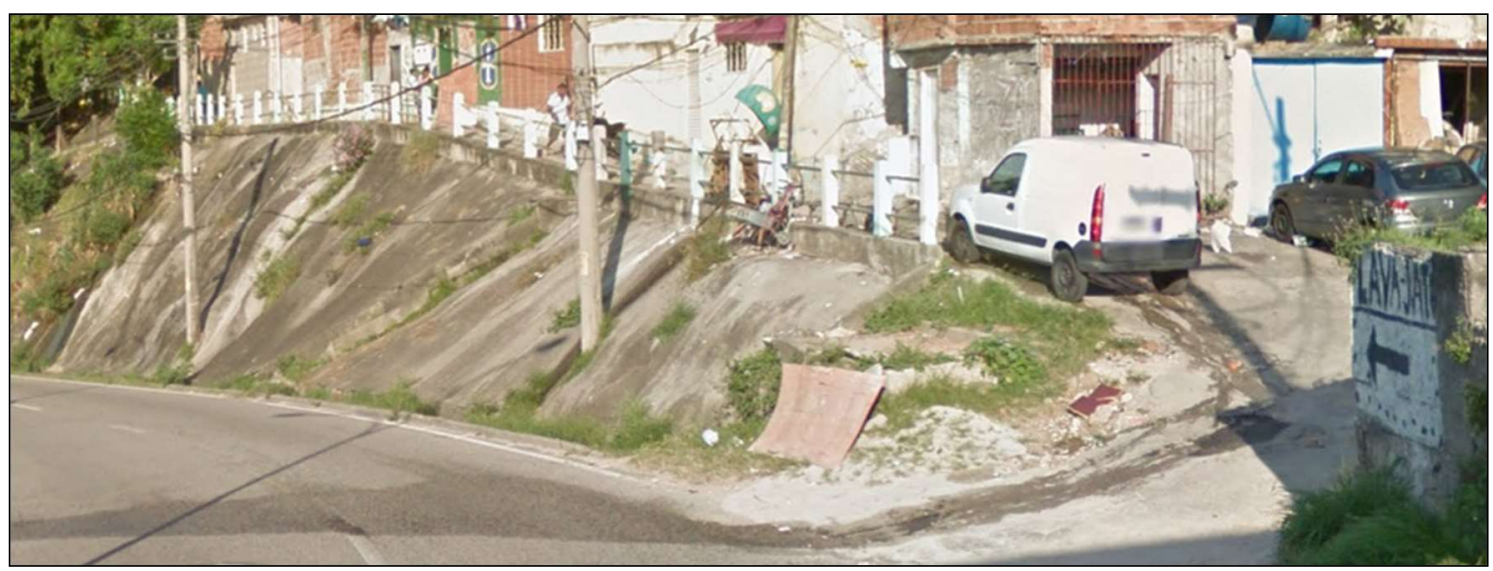

Figura 6.19: Lava a jato no entorno da Avenida Menezes Cortes. 
Não foi identificado na via um sistema de apoio a usuários. A Figura 6.20 mostra uma placa de alerta do que se pode esperar da via quanto a todos as suas características na previsão de futuros acidentes.

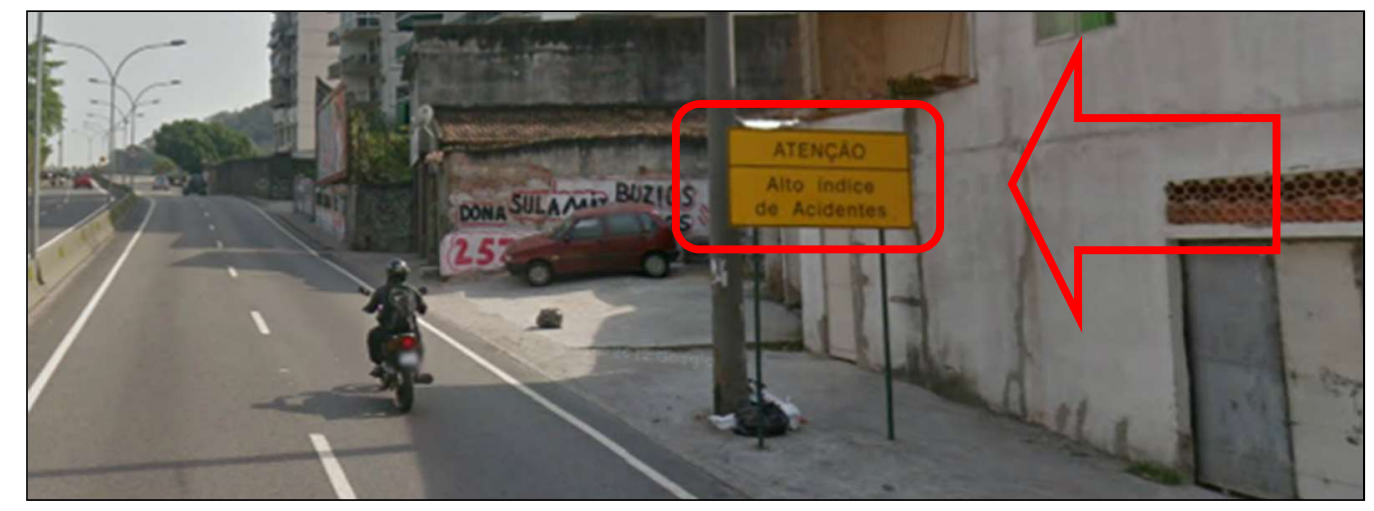

Figura 6.20: Placa de alerta no início da via no bairro do Grajaú.

Fonte: Google Maps (2015).

\subsection{VISITA AO GRUPAMENTO DE BOMBEIRO}

Foi realizada uma entrevista com os bombeiros do $2^{\circ}$ Destacamento do $11^{\circ}$ Grupamento de Bombeiro Militar (GBM) do Grajaú, que enfatizaram que, devido ao grande número de ônibus e caminhões que trafegam na via, há um frequente derramamento de diesel e óleo na pista, o que causa o deslizamento de veículos e, principalmente, de motos.

Foi unânime entre os profissionais de segurança que a via carece de dispositivos que contenham os veículos desgovernados nas ribanceiras, como por exemplos defensas metálicas ou muretas, e placas de sinalização, principalmente na descida no sentido Grajaú e nas regiões de retorno.

\subsection{ANÁLISE DA CONSISTÊNCIA GEOMÉTRICA}

\subsubsection{Determinação da Velocidade Operacional Potencial - V85p}

A $\mathrm{V}_{85 p}$ utiliza como dados de entrada os elementos planialtimétricos da via. O seu cálculo decorre da aplicação da fórmula 6, modelada e validada por Garcia (2008):

$$
V_{85}=93,1545-\frac{1666,1716}{R}-1,1872 \times L-0,4654 \times|I|-1,3426 \times A
$$


Como resultado tem-se a $\mathrm{V}_{85 \mathrm{p}}$ calculada por sentido da via e para cada estaca, visto que as curvas à direita e à esquerda, e declives e aclives tem contribuições diferentes na $\mathrm{V}_{85 \mathrm{p}}$. $\mathrm{O}$ processamento desta fórmula ocorreu integralmente no software Saepro.

\subsubsection{Determinação da Velocidade Operacional Efetiva - V85e}

A V85e utiliza como dados de entrada a velocidade operacional, potenciais taxas de aceleração e o fator de redução para desempenho em aclives. As velocidades inicial e final (medidas ou arbitradas) são também utilizadas como partida nos sentidos da via (a favor e contra o estaqueamento). A $\mathrm{V}_{85 \mathrm{e}}$ é calculada de forma a não ultrapassar a velocidade operacional da mesma, utilizando a $\mathrm{V}_{85 \mathrm{e}}$ da estaca anterior como referência e a taxa de aceleração como fator de redução em aclives, segundo as condicionantes geométricas da via. O processamento desta etapa ocorreu integralmente no software Saepro. O resultado final é uma planilha a ser utilizada para geração de relatórios.

\subsubsection{Critérios de classificação I, II e ICG}

Após o perfil de velocidades ter sido criado por sentido da via, ele é confrontado com a velocidade de projeto (critério de segurança I) e entre si, para elementos planimétricos distintos (critério de segurança 2). O ICG é obtido da composição dos critérios de segurança I e II. Todo o processamento desta etapa ocorre em planilha automatizada, desenvolvida em Excel, gerando o relatório de análise da consistência geométrica (Figura 6.21 e Figura 6.22):

A Figura 6.21 e a Figura 6.22 apresentam a classificação de acordo com os critérios de segurança I e II da Avenida Menezes Cortes, que foi desenvolvida de acordo com as recomendações apresentadas nos itens 4.2.1 e 4.2.2. As barras coloridas com a análise da consistência geométrica são dadas por uma classificação que envolve três cores: verde para a classificação "projeto bom" do segmento; amarela para "projeto regular"; vermelha para "projeto fraco". 


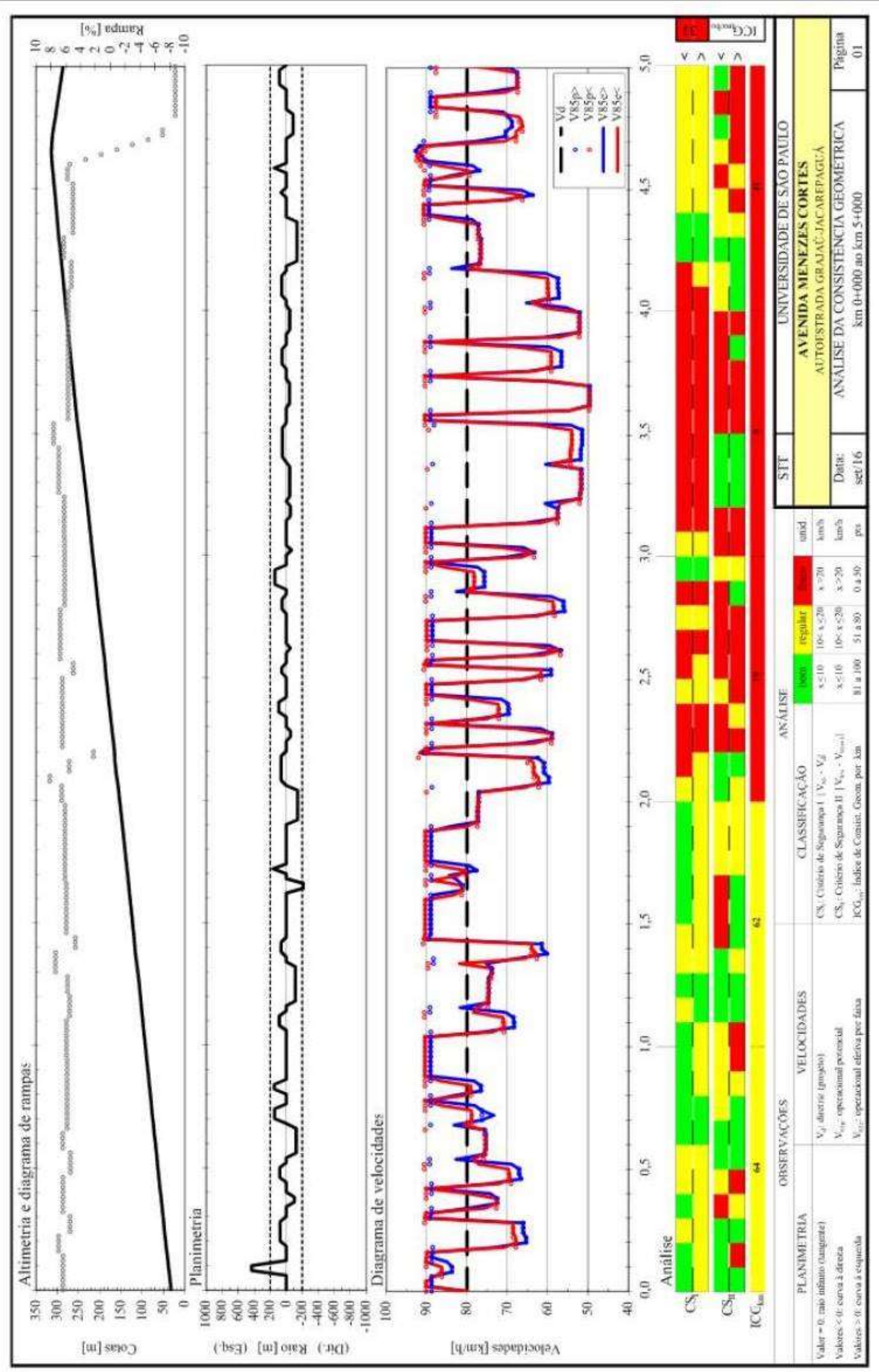

Figura 6.21: Primeira página do relatório de classificação pelo $\mathrm{CS}_{\mathrm{I}}, \mathrm{CS}_{\mathrm{II}}, \mathrm{ICG}_{\mathrm{km}}, \mathrm{ICG}_{\text {trecho. }}$ 


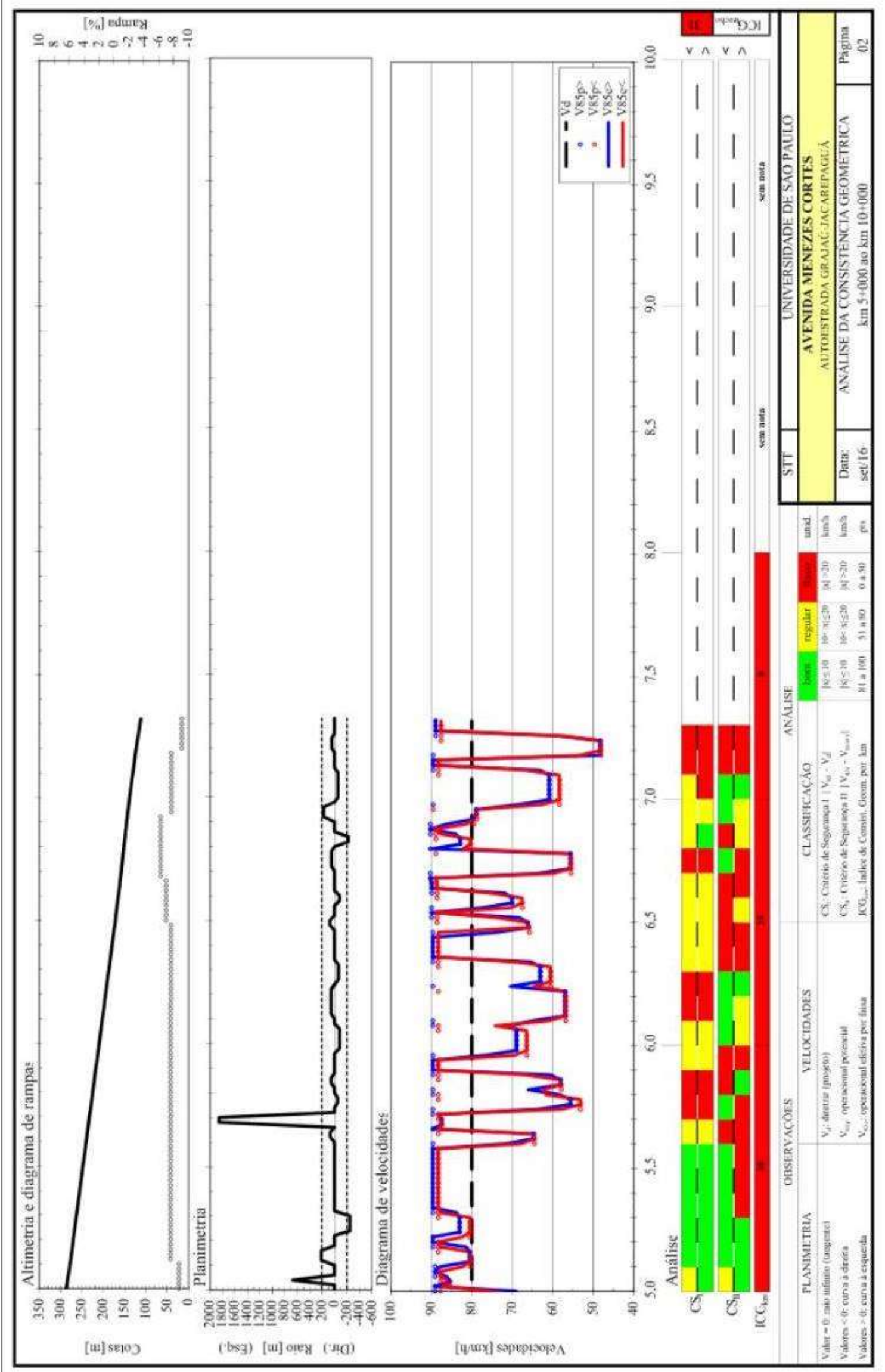

Figura 6.22: Segunda página do relatório de classificação pelo $\mathrm{CS}_{\mathrm{I}}, \mathrm{CS}_{\mathrm{II}}, \mathrm{ICG}_{\mathrm{km}}, \mathrm{ICG}_{\mathrm{trecho}}$. 
A análise pelo critério de segurança I foi realizada para cada sentido da via. A Tabela 6.5 apresenta a extensão da via classificada de acordo com a análise do $\mathrm{CS}_{\mathrm{I}}$. É possível observar que boa parte da rodovia se enquadrou nas classificações "projeto regular" e "projeto fraco". Esse dado é preocupante, uma vez que a via está sendo utilizada por condutores trafegando em velocidades que diferem em mais de $10 \mathrm{~km} / \mathrm{h}$ da velocidade de projeto. Recomenda-se que seja realizada uma reavaliação, principalmente nos quilômetros onde a via foi classificada como fraca.

Tabela 6.5: Classificação da Avenida Menezes Cortes pelo critério de segurança I

\begin{tabular}{|c|c|c|c|c|}
\hline \multirow{2}{*}{$\begin{array}{c}\text { Extensão } \\
\text { [km] }\end{array}$} & \multirow{2}{*}{$\begin{array}{c}V d \\
{[\mathrm{~km} / \mathrm{h}]}\end{array}$} & \multicolumn{3}{|c|}{$\begin{array}{c}\text { Critério de segurança I } \\
\text { [km] (2 sentidos) }\end{array}$} \\
\hline & & Fraco & Regular & Bom \\
\hline 14,8 & 80 & $\begin{array}{c}4,7 \\
(31,8 \%)\end{array}$ & $\begin{array}{c}6,5 \\
(43,9 \%)\end{array}$ & $\begin{array}{c}3,6 \\
(24,3 \%)\end{array}$ \\
\hline
\end{tabular}

A Tabela 6.6 apresenta a extensão da via classificada de acordo com a análise pelo critério de segurança II para cada sentido da via. A via apresentou mais trechos enquadrados nas classificações "projeto fraco" e "projeto regular" do que em "projeto bom". Ou seja, mais da metade da via apresentou variações de velocidades operacionais superiores a $10 \mathrm{~km} / \mathrm{h}$. Dado esse resultado, são recomendáveis as realizações de reavaliações, principalmente, nos quilômetros onde a via foi classificada como fraca.

Tabela 6.6: Classificação da Avenida Menezes Cortes pelo critério de segurança II

\begin{tabular}{c|cccc}
\hline \multirow{2}{*}{$\begin{array}{c}\text { Extensão } \\
{[\mathbf{k m}]}\end{array}$} & $\boldsymbol{V}_{\boldsymbol{d}}$ & \multicolumn{3}{c}{ Critério de segurança II } \\
{$[\mathbf{k m}]$ (2 sentidos) } \\
\hline $\mathbf{k m} / \mathbf{h}]$ & Fraco & Regular & Bom \\
\hline 14,64 & 80 & 6,4 & 3,0 & 5,4 \\
& & $(43,2 \%)$ & $(20,3 \%)$ & $(36,5 \%)$ \\
\hline
\end{tabular}

O índice de consistência geométrica por trecho - $\mathrm{ICG}_{\text {trecho }}$ calculado foi de 31 . É um índice considerado extremamente baixo, porém o índice tem uma função de comparação e classificação. A análise pelo índice de consistência geométrica por quilômetro - ICG $\mathrm{Im}_{\mathrm{km}}$ foi decorrente da composição dos critérios de segurança I e II, considerando ambos os sentidos da via. A Tabela 6.7 apresenta os quilômetros classificados de acordo com o ICGkm. É 
possível observar que toda a rodovia se enquadrou nas classificações "projeto fraco" e “projeto regular”, com preponderância na primeira.

Tabela 6.7: Classificação da Avenida Menezes Cortes pelo $\mathrm{ICG}_{\mathrm{km}}$

\begin{tabular}{c|cccc}
\hline $\begin{array}{c}\text { Extensão } \\
{[\mathbf{k m}]}\end{array}$ & $\begin{array}{c}\mathbf{V}_{\mathbf{d}} \\
{[\mathbf{k m} / \mathbf{h}]}\end{array}$ & Fraco & Regular & Bom \\
\hline 8 & 80 & 6 & 2 & 0 \\
& & $(75 \%)$ & $(25 \%)$ & $(-\%)$ \\
\hline
\end{tabular}

\subsection{ANÁLISE DOS BANCOS DE DADOS DE ACIDENTES}

\subsubsection{Os bancos de dados dos acidentes}

Os bancos de dados de acidentes de trânsito contemplaram 401 acidentes registrados na Avenida Menezes Cortes no Rio de Janeiro entre os anos de 2011 e 2015. Os dados de 2011 a 2014 são do Instituto de Segurança Pública (ISP), órgão da Secretaria de Estado de Segurança, e refletem as ocorrências atendidas no local do acidente, mediante solicitação de viatura da Polícia Militar pelo número 190. As coordenadas foram geradas pelo GPS da viatura e validadas na CET-Rio, devido ao erro inerente a eventual instabilidade no sinal do GPS quando da ida da viatura ao local. Os dados de 2014 e 2015 foram fornecidos pela Polícia Civil, a partir de ocorrências registradas nas delegacias legais do município (o que explica o menor número de registros, uma vez que nem sempre os envolvidos em acidentes se dispõem a ir a uma delegacia) e o georreferenciamento foi feito na CET-Rio, a partir das referências informadas.

A estrutura do banco de dados do ISP (2011 a 2014) inclui informações básicas de localização no tempo (data e hora) e no espaço (georreferenciamento) de cada acidente, informações verificadas no momento do acidente e que são fundamentais no estudo dos tipos de acidentes. Essa estrutura é descrita a seguir:

- "Data": Dia, mês e ano em que ocorreu o acidente.

- "Hora": Hora de ocorrência do acidente.

- "Dia da semana": Dia da semana em que ocorreu o acidente.

- "Faixa de horário": Faixa horária em que ocorreu o acidente. 
- "Logradouro": Nome da avenida onde foi registrado o acidente (Avenida Menezes Cortes).

- "Bairro": Bairro onde foi registrado o acidente.

- "Complement": Informações complementares do acidente.

- “Tipo": Classificação do acidente quanto à natureza ou maneira como ocorreu (atropelamento, capotamento com vítima, colisão com vítima tombamento com vítima).

- "X": Coordenada X da viatura no momento do preenchimento do Boletim de Ocorrência.

- "Y": Coordenada Y da viatura no momento do preenchimento do Boletim de Ocorrência.

- "Sentido": sentido que o motorista estava seguindo na rodovia.

A estrutura do banco de dados a Polícia Civil (2014-2015) é semelhante à do ISP e inclui informações básicas de localização no tempo (data) e no espaço (georreferenciamento) de cada acidente, informações verificadas no momento do acidente e que são fundamentais no estudo dos tipos de acidentes. Essa estrutura é descrita a seguir:

- "locf": Nome da avenida onde foi ocorreu o acidente (Avenida Menezes Cortes).

- "ftlo": Tipo do logradouro onde foi ocorreu o acidente (Avenida).

- "flog": Nome do logradouro onde ocorreu o acidente (Menezes Cortes).

- “fnum”: Numeração do logradouro próximo onde ocorreu o acidente.

- "km": Km em que ocorreu o acidente.

- "sent": Sentido da via em que ocorreu o acidente.

- "fref": Referência da proximidade onde ocorreu o acidente.

- "localidade": Localidade onde ocorreu o acidente.

- "fbai": Bairro onde ocorreu o acidente.

- "X": Coordenada X do acidente georreferenciado pela CET-Rio a partir das referências informadas.

- "Y": Coordenada Y do acidente georreferenciado pela CET-Rio a partir das referências informadas.

- "dscr": Descrição do acidente quanto à natureza ou maneira como ocorreu (homicídio culposo (outros) (Lei 9503/97); homicídio culposo provocado por atropelamento; lesão corporal culposa (outros) (Lei 9503/97); lesão corporal culposa provocada por 
atropelamento; lesão corporal culposa provocada por capotagem; lesão corporal culposa provocada por colisão com ponto fixo e lesão corporal culposa provocada por colisão de veículo).

- "datfdia": Dia em que ocorreu o acidente.

- "datfdmes": Mês em que ocorreu o acidente.

- "datfano": Ano em que ocorreu o acidente.

- "datf": Dia, mês e ano em que ocorreu o acidente.

\subsubsection{Distribuição das frequências dos acidentes}

Os bancos de dados dos registros dos acidentes foram estudados e analisados. A Tabela 6.8 mostra o número absoluto de acidentes por trecho e na totalidade da Avenida Menezes Cortes, num período de cinco anos. A tabela mostra que nos anos iniciais o KM 6 era o trecho com maior número de acidentes e com o passar dos anos o KM 1 passou a ser o segmento com mais acidentes. Apesar da abreviação de quilômetro ser km, utilizou-se o termo em maiúsculas para designar o trecho KM N entre as marcações do (N-1) km e do $\mathrm{N}$ $\mathrm{KM}$, como, por exemplo, o KM 1 corresponde o trecho entre as marcações de $0 \mathrm{~km}$ e de 1 $\mathrm{km}$.

Ao se compilar o número de acidentes em relação a toda a avenida, a Figura 6.23 destaca o primeiro quilômetro e o sexto. Tal fato pode ser observado devido a uma queda brusca no número dos acidentes dos outros trechos. Também foram colocados os registros de todos os acidentes em uma base do Google Maps para se obter uma melhor visualização dos dados (Figura 6.24 a Figura 6.26).

Tabela 6.8: Número de acidentes por km

\begin{tabular}{l|ccccc}
\hline Trecho & $\mathbf{5}$ & Ano \\
& $\mathbf{2 0 1 1}$ & $\mathbf{2 0 1 2}$ & $\mathbf{2 0 1 3}$ & $\mathbf{2 0 1 4}$ & $\mathbf{2 0 1 5}^{*}$ \\
\hline KM 1 & 29 & 17 & 12 & $\mathbf{3 1}$ & $\mathbf{1 2}$ \\
KM 2 & 11 & 8 & $\mathbf{1 7}$ & 9 & 4 \\
KM 3 & 8 & 8 & 5 & 17 & 1 \\
KM 4 & 9 & 10 & 0 & 1 & 2 \\
KM 5 & 17 & 8 & 0 & 5 & 1 \\
KM 6 & $\mathbf{5 3}$ & $\mathbf{2 5}$ & 0 & 3 & 4 \\
KM 7 & 30 & 21 & 3 & 5 & 0 \\
\hline
\end{tabular}




\begin{tabular}{c|ccccc}
\hline KM 8 & 10 & 3 & 1 & 1 & 0 \\
\hline $\begin{array}{c}\text { Avenida Menezes } \\
\text { Cortes }\end{array}$ & 167 & 100 & 38 & 72 & 24 \\
\hline
\end{tabular}

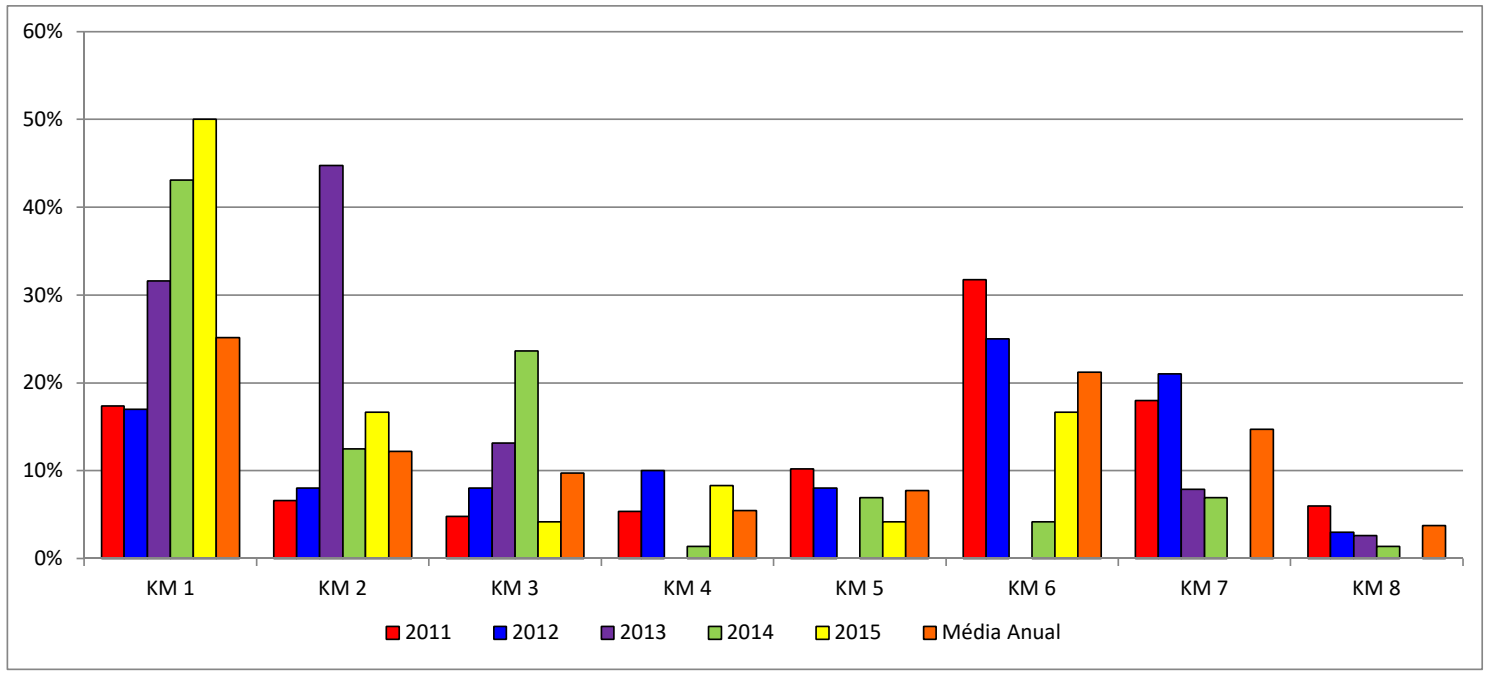

Figura 6.23: Porcentagens de acidentes por trecho.
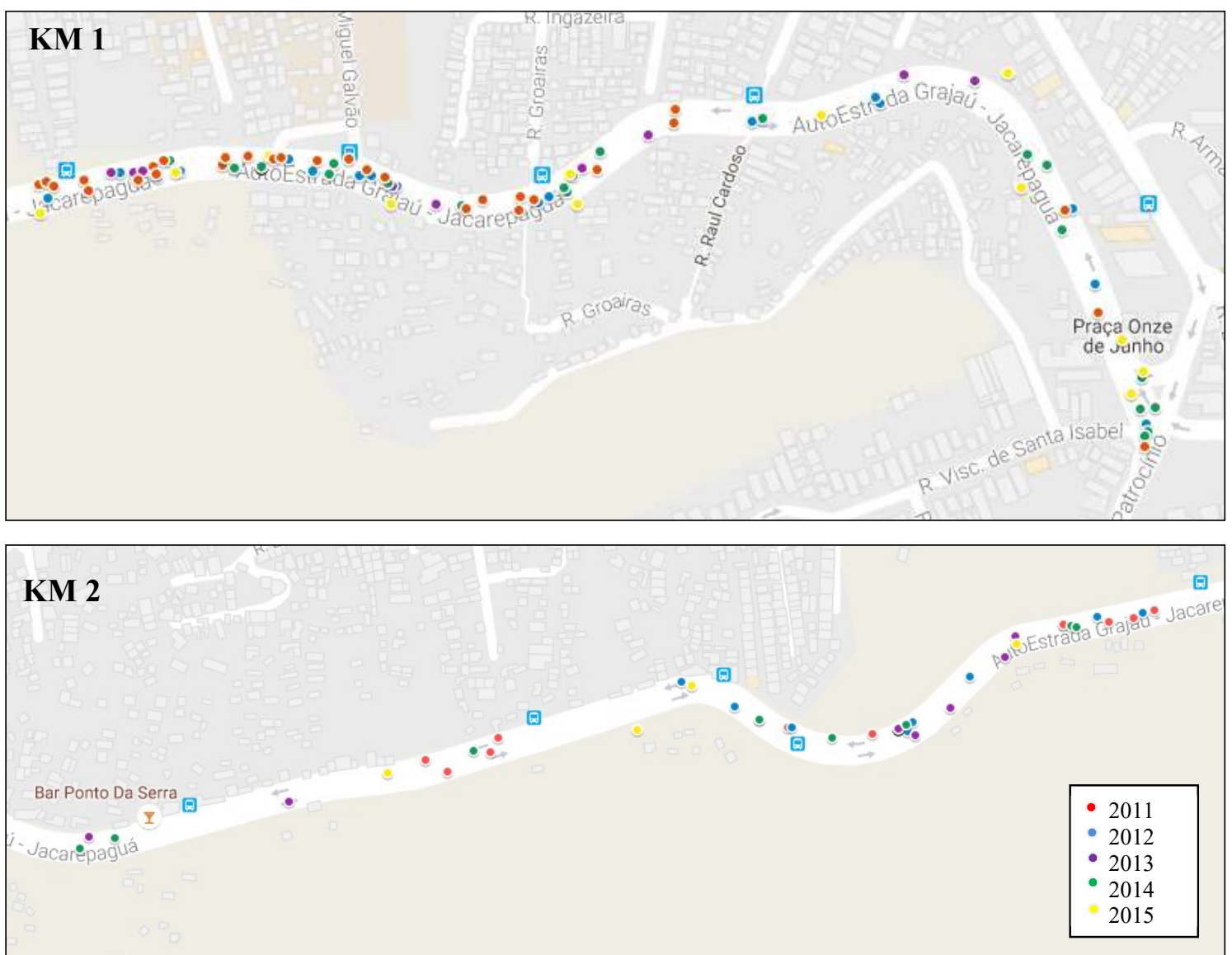

Figura 6.24: Localização dos acidentes de trânsito por ano nos trechos KM 1 e KM 2. 


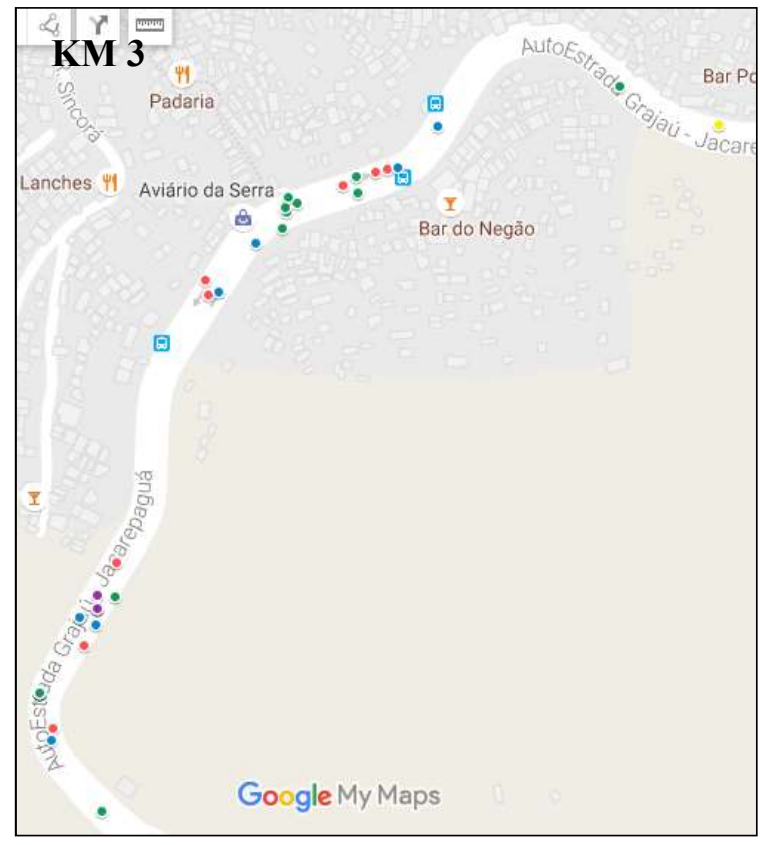

\section{KM 4}
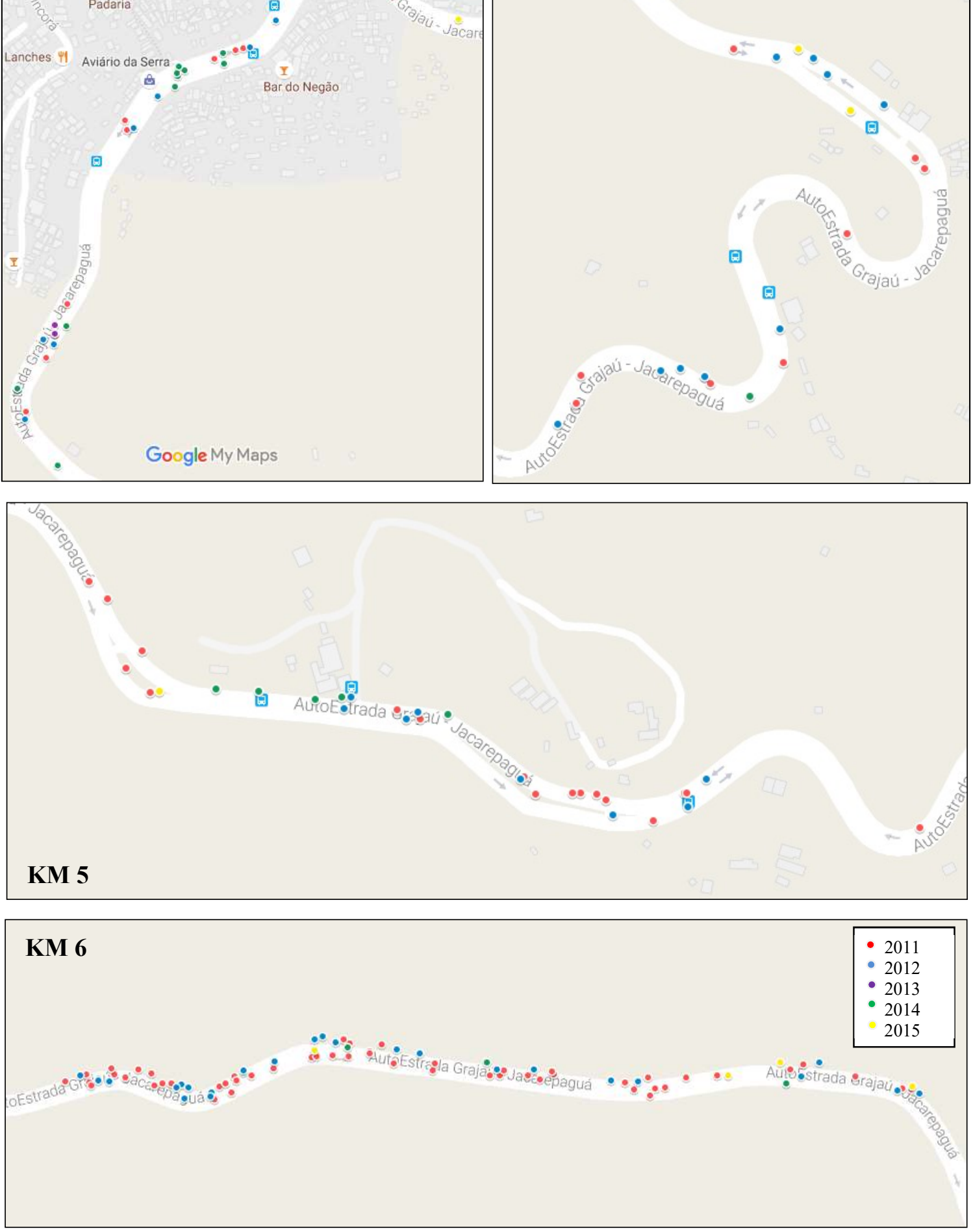

Figura 6.25: Localização dos acidentes de trânsito por ano nos trechos KM3, KM4, KM 5 e KM6. 

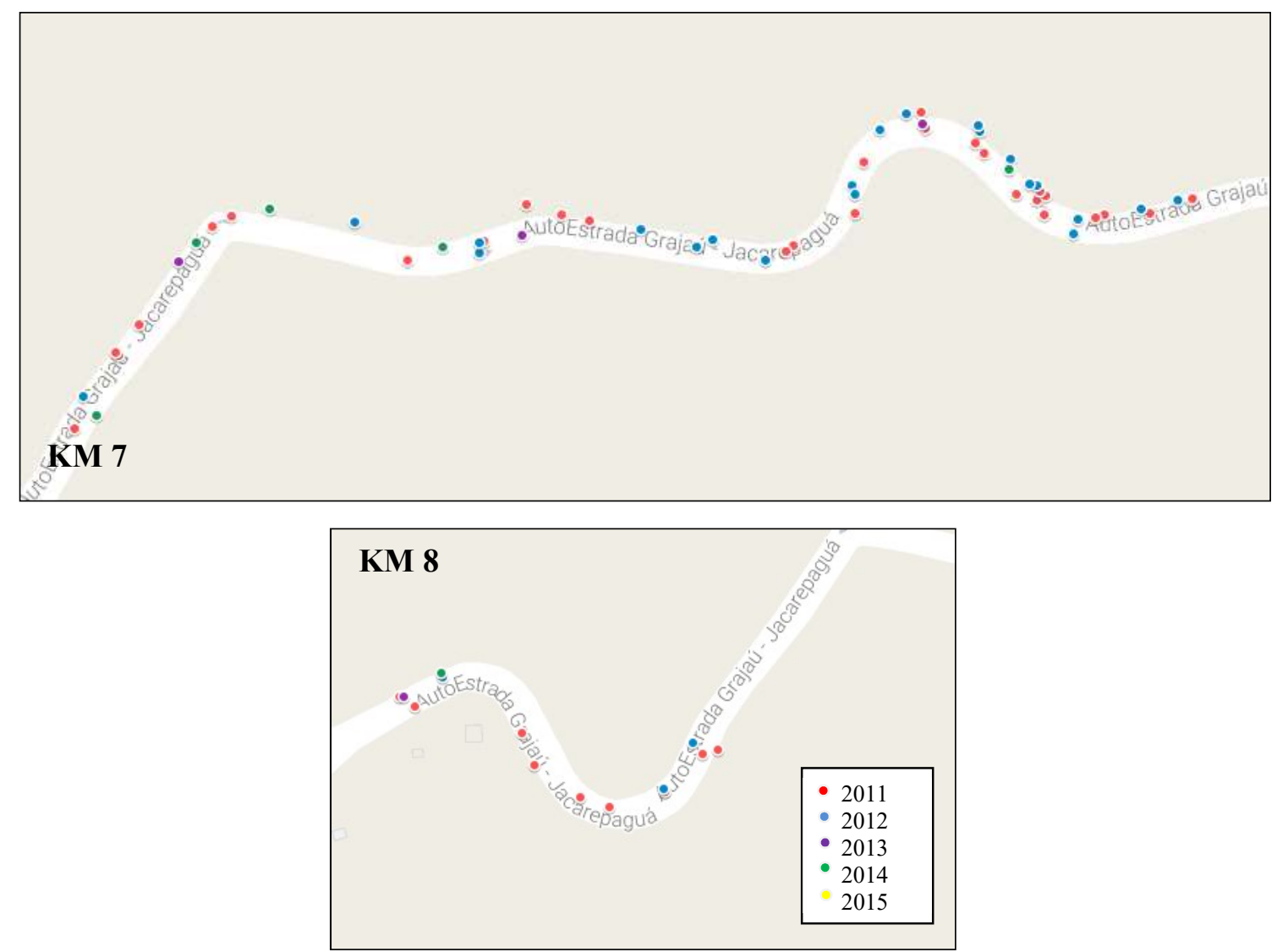

Figura 6.26: Localização dos acidentes de trânsito por ano nos trechos KM 7 e KM 8.

Foi utilizado apenas o banco de dados do ISP para analisar os tipos de acidentes, devido ao banco de dados da Polícia Militar não classificar os acidentes por tipo, mas por tipo de lesão corporal. Dessa forma, ao se analisar os 358 acidentes, a colisão foi o tipo mais frequente, seguido por capotamento e tombamento, que são altamente relacionados à perda de controle do carro decorrente da imprudência (Tabela 6.9 e Figura 6.27). Também foram colocados os registros de todos os acidentes por tipo em uma base do Google Maps para se obter uma melhor visualização dos dados (Figura 6.28 a Figura 6.29).

Tabela 6.9: Número de acidentes por tipo distribuídos por trecho

\begin{tabular}{c|ccccccccc}
\hline Tipo de Acidente & $\boldsymbol{K M}$ & $\boldsymbol{K M}$ & $\boldsymbol{K M}$ & $\boldsymbol{K M}$ & $\boldsymbol{K M}$ & $\boldsymbol{K M}$ & $\boldsymbol{K M}$ & $\boldsymbol{K M}$ & Total \\
\hline Atropelamento & $\mathbf{1}$ & $\mathbf{2}$ & $\mathbf{3}$ & $\mathbf{4}$ & $\mathbf{5}$ & $\mathbf{6}$ & 7 & $\boldsymbol{8}$ & Geral \\
\hline Capotamento com vítima & 9 & 4 & 2 & 1 & 4 & 2 & 3 & - & 25 \\
Colisão com vítima & 21 & 9 & 10 & 6 & 5 & 31 & 18 & 5 & 105 \\
Tombamento com vítima & 33 & 18 & 11 & 10 & 11 & 33 & 22 & 7 & 145 \\
\hline Total & 19 & 10 & 10 & 3 & 8 & 15 & 15 & 3 & 83 \\
\hline
\end{tabular}




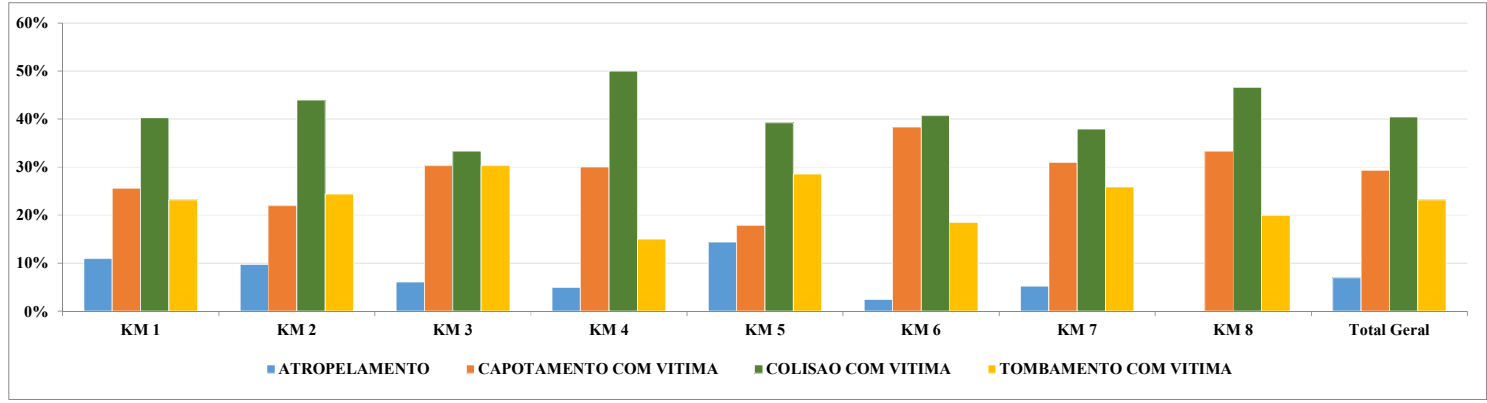

Figura 6.27: Porcentagem dos acidentes em função do tipo.
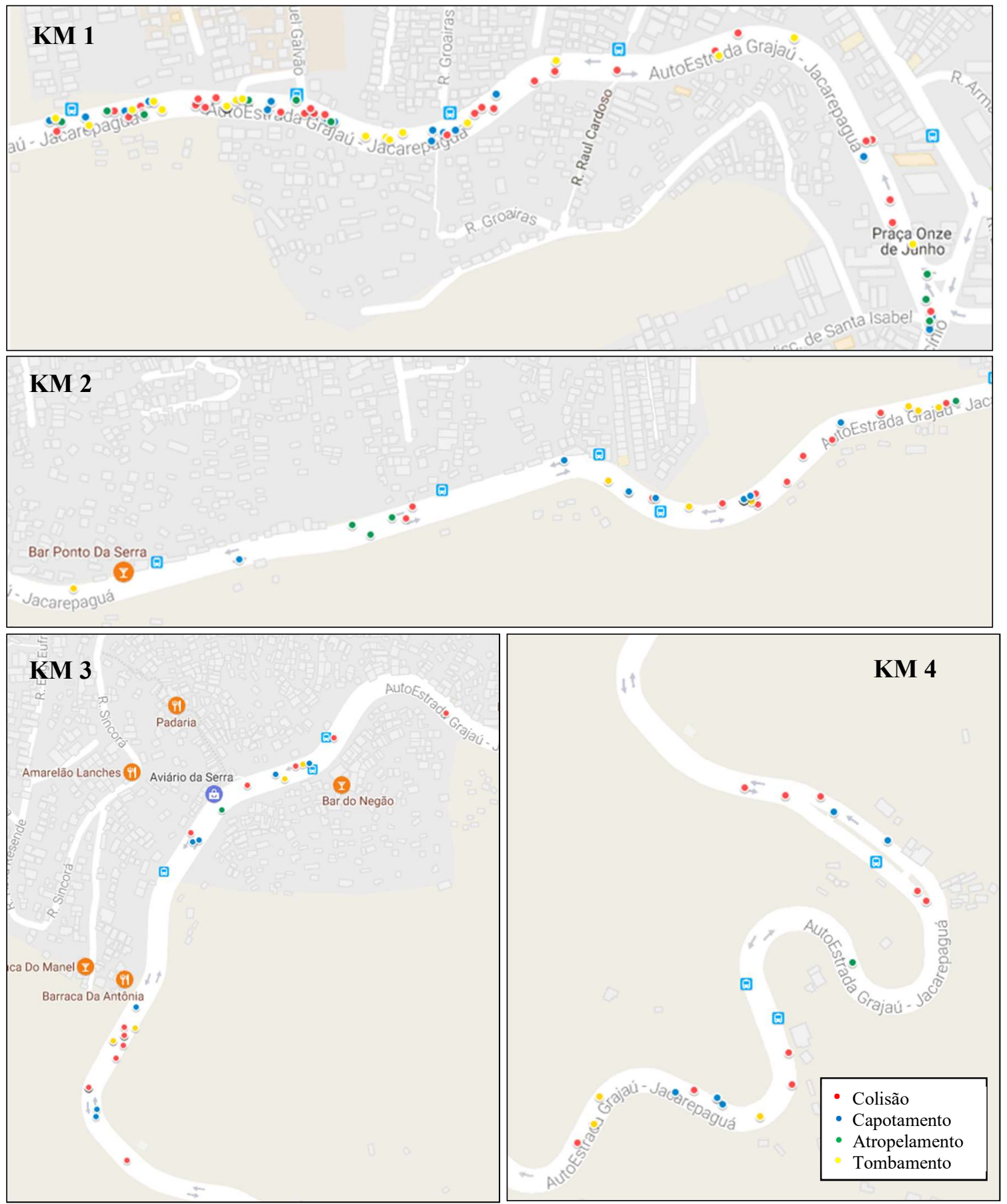

Figura 6.28: Localização dos acidentes de trânsito por tipo nos trechos KM 1, KM 2, KM3 e KM4. 

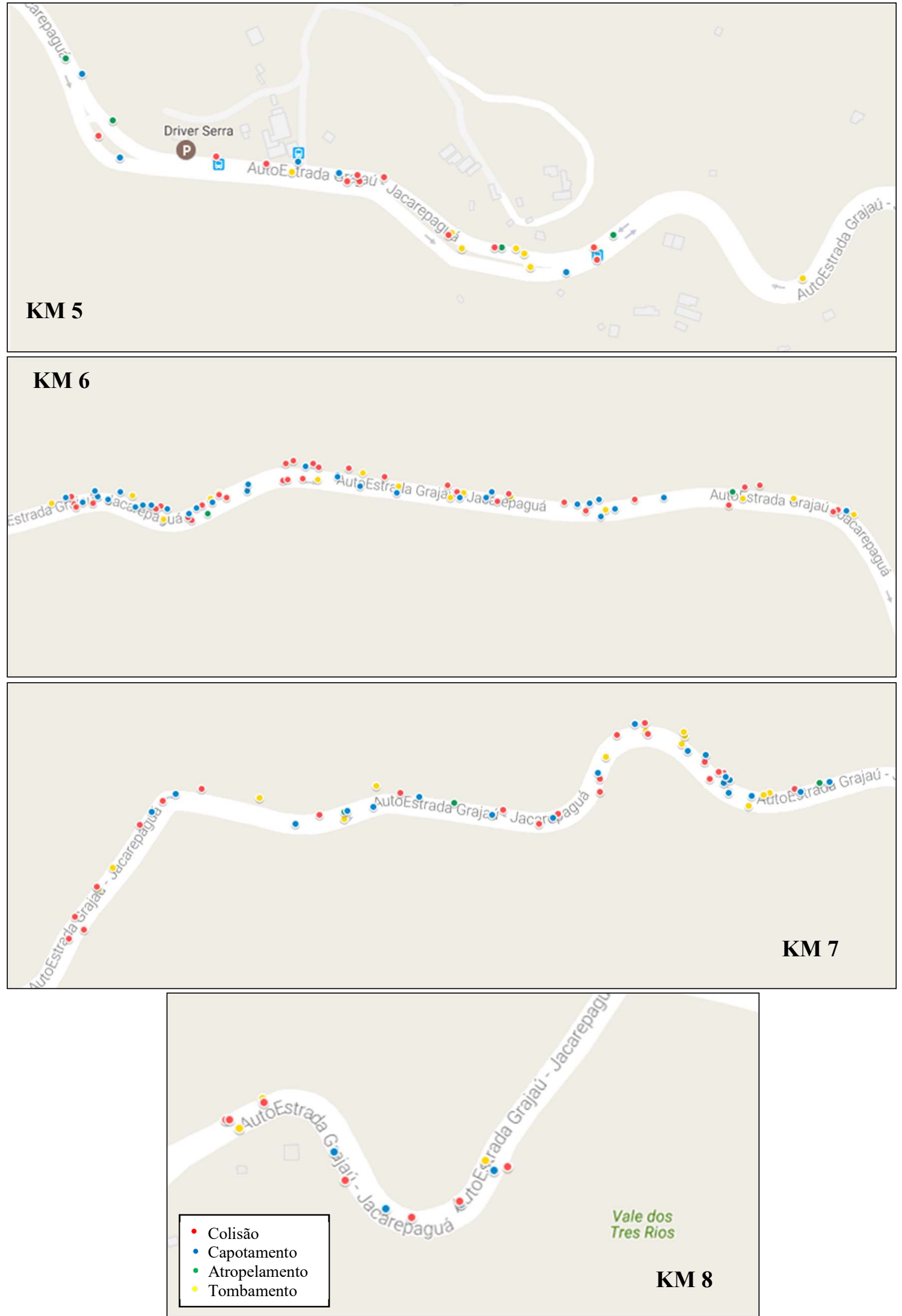

Figura 6.29: Localização dos acidentes de trânsito por tipo nos trechos KM5, KM6, KM 7 e KM 8. 
De forma a tentar entender o comportamento dos motoristas da Autoestrada GrajaúJacarepaguá, também foram estudadas as horas em que os acidentes ocorrem durante o dia (Figura 6.30), os dias da semana (Figura 6.31) e também os meses (Figura 6.32).

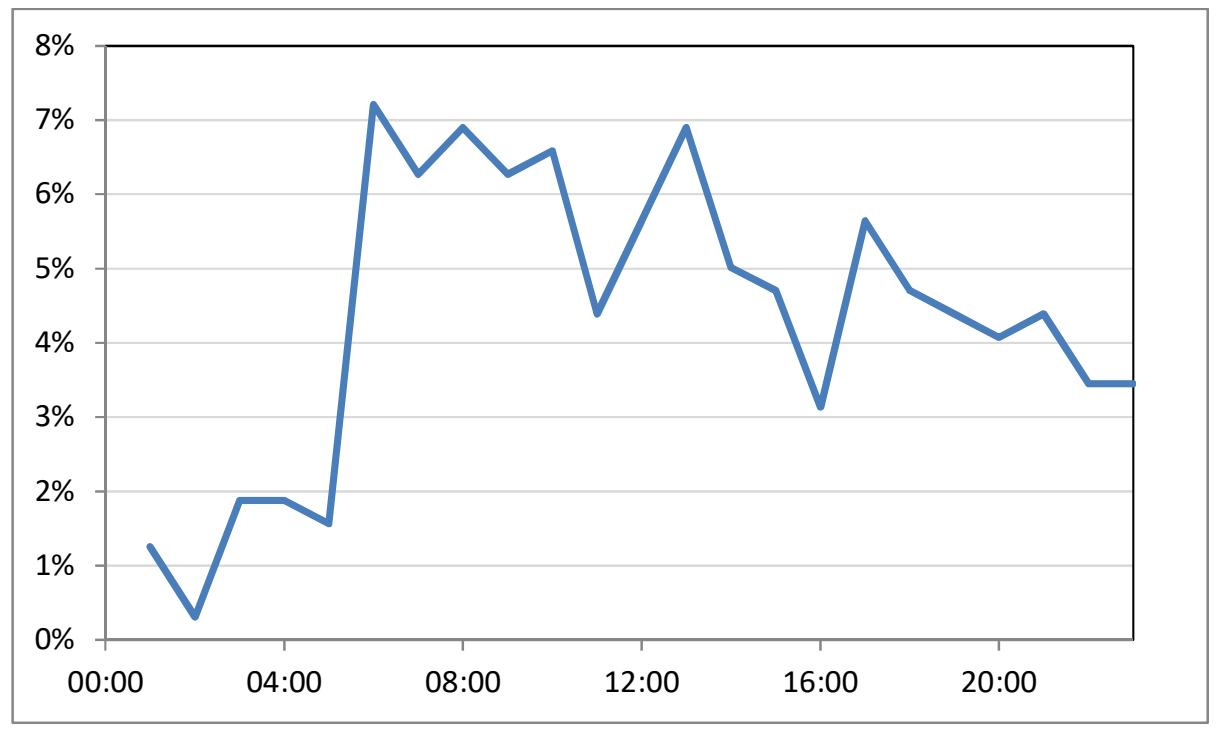

Figura 6.30: Porcentagem dos acidentes em função das horas do dia.

Ao se analisar os acidentes em função das horas em que eles ocorrem, pode-se perceber que a maioria acontece pela manhã, entre 6 e 10 horas da manhã, correspondendo a 33\% de todos os acidentes. Foram retirados dos estudos os 82 acidentes que ocorrem à 0 hora, pois eles se mostraram em um número bastante alto de observações (20\%). Tal fato pode ser relacionado com a forma com que os acidentes foram registrados e ao não se preencher a hora em que eles acontecem, o autopreenchimento marca à 0 hora.

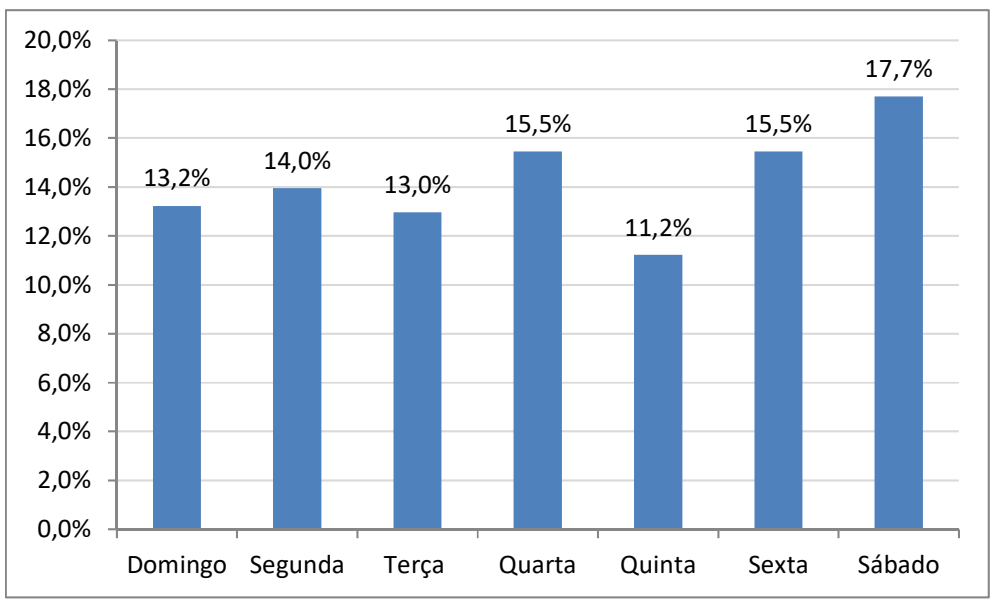

Figura 6.31: Porcentagem dos acidentes em função dos dias da semana. 
Com relação aos dias da semana, visualiza-se que os acidentes ocorrem com um pouco mais de frequência nas sextas e sábados e nas quartas-feiras.

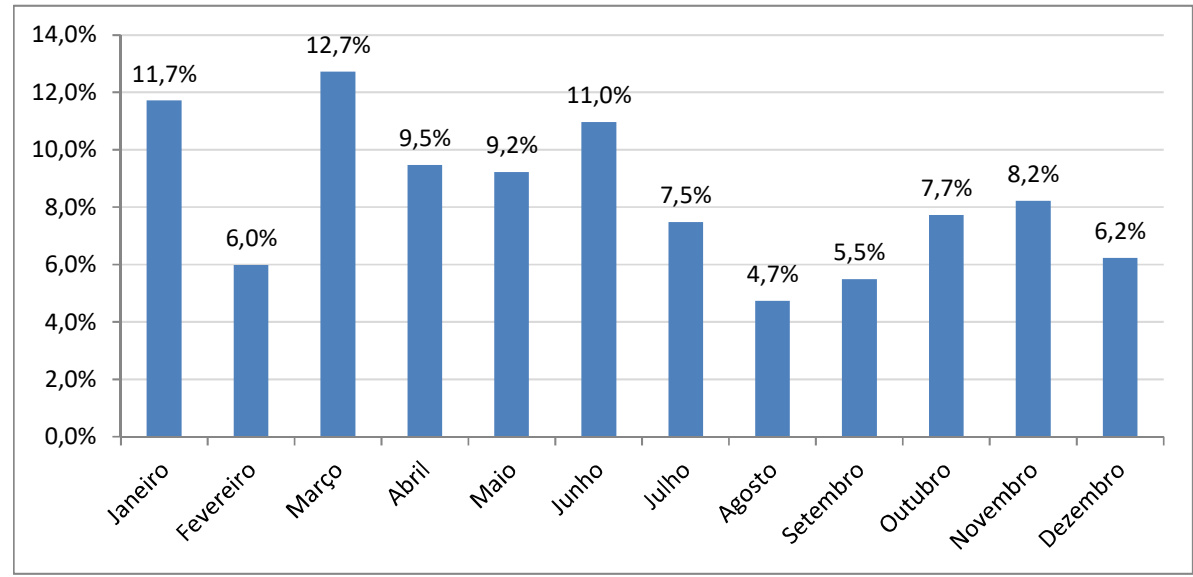

Figura 6.32: Porcentagem dos acidentes em função dos meses.

Com relação aos meses do ano, pode-se observar que há uma divisão entre janeiro e junho com maiores acidentes e de julho a dezembro sendo caracterizados como meses com menos acidentes.

\subsection{RELAÇÃO DOS ACIDENTES COM AS CARACTERÍSTICAS DA VIA}

\subsubsection{Traçado}

No estudo de caso, foram avaliados 8 quilômetros da Avenida Menezes Cortes. A classificação destes quilômetros, segundo sua consistência geométrica, é observada na Tabela 6.10.

Tabela 6.10: Classificação por quilômetro

\begin{tabular}{ccccc}
\hline \multicolumn{2}{c}{ Classificação ICG $\boldsymbol{G}_{\boldsymbol{k} \boldsymbol{m}}$} & $\boldsymbol{k m}$ & \multicolumn{2}{c}{ Acidentes/Ano } \\
Caso & Intervalo & & Média & $\boldsymbol{\sigma}$ \\
\hline Bom & 81 a 100 & - & - & - \\
Regular & 51 a 80 & 2 & 15,00 & 7,35 \\
Fraco & 0 a 50 & 6 & 8,37 & 5,21 \\
\hline
\end{tabular}

Observando os dados da Tabela 6.10, é possível observar que a via está classificada, basicamente em "projeto fraco" (75\%) e "projeto regular" (25\%) e que as médias de acidentes por ano foram maior na classificação "projeto regular", o que de certa forma é esperado, uma vez que a maioria das velocidades utilizadas para classificar os quilômetros em "projeto fraco" foi menor que a velocidade de projeto, dando um maior tempo de percepção e reação para os motoristas para o caso de algum incidente. 
A Figura 6.33 apresenta o gráfico com os dados de acidentes anuais em função dos $\mathrm{ICG}_{\mathrm{km}}$. A linha de tendência da figura apresenta coeficiente de determinação igual a 0,50 , indicando a 50\% variabilidade do número de acidentes anuais pode ser explicada pelo $\mathrm{ICG}_{\mathrm{km}}$.

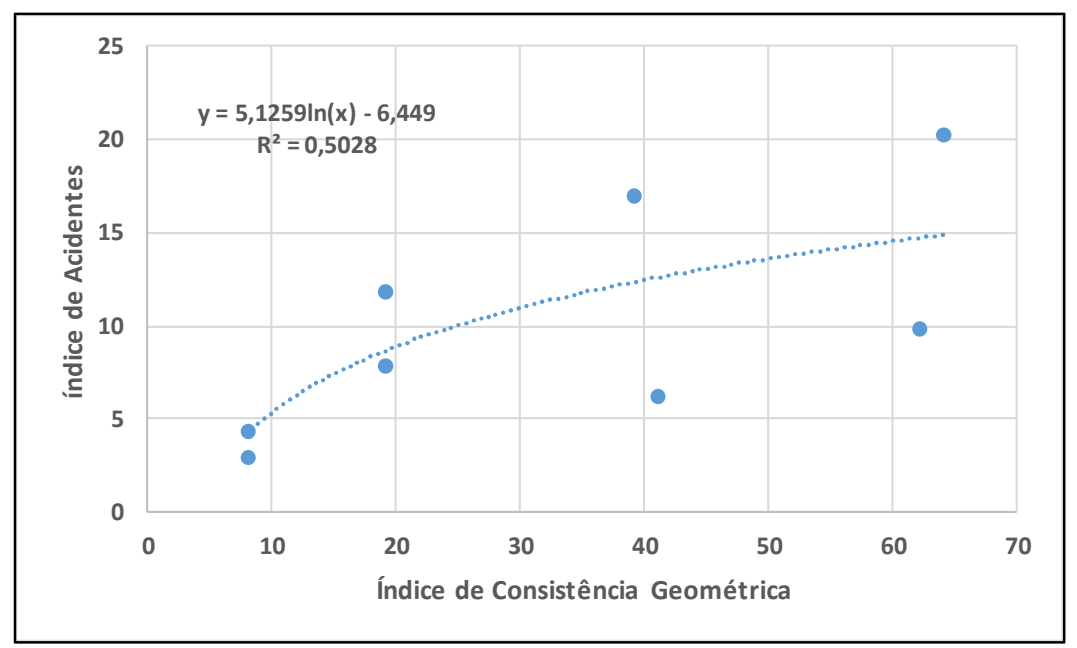

Figura 6.33: Acidentes anuais em função do $\mathrm{ICG}_{\mathrm{km}}$.

O estudo que Garcia (2008) realizou, em que indica que o número de acidentes diminui conforme o ICG aumenta, se mostra controverso ao do presente estudo, que mostra um aumento do número de acidentes conforme o aumento do ICG. Isso pode ser relacionado ao baixo número de trechos de classificação "projeto regular" do estudo de Garcia e a falta de trechos de "projeto bom" deste estudo, gerando uma lacuna intervalo do ICG. Como a função se mostra crescente para intervalos baixos de ICG e decrescente para os intervalos altos, a sugestão é de que há um número máximo de acidentes dado um valor de intervalo médio de ICG. Tal fato corrobora para que a análise da consistência geométrica forneça subsídios para a análise da segurança viária. No entanto, o desenvolvimento de um modelo de estimativa de acidentes não foi objeto do trabalho.

\subsubsection{Seção transversal}

A Avenida Menezes Cortes apresenta duas faixas por sentido, sem acostamentos, mas oferecendo uma condição de ultrapassagem aos motoristas. A via apresenta tráfego de veículos pesados, como ônibus e caminhões, que, nos greides de subida, apresentam velocidades reduzidas e algumas curvas apresentam problemas no que tange à superelevação e à superlargura. 
Ao realizar a aceleração para a manobra de ultrapassagem principalmente ao final das curvas, em que algumas não apresentam superelevação e superlargura, o motorista pode perder o controle e atingir a barreira de concreto, que, por ser rígida e não absorver o impacto, joga o motorista de volta, ainda com velocidade elevada, fazendo com que saia pela a lateral da via, que apresenta condições fracas de segurança para veículos desgovernados.

Em vistoria realizada, notou-se que as barreiras de concreto ao final das curvas apresentavam marcas devido às batidas com carros e que as barreiras longitudinais de contenção ou se apresentavam recentemente instaladas, ou danificadas, sendo uma delas danificada dias antes da vistoria, em decorrência de um acidente gravíssimo com duas mortes (Figura 6.34 e Figura 6.35).
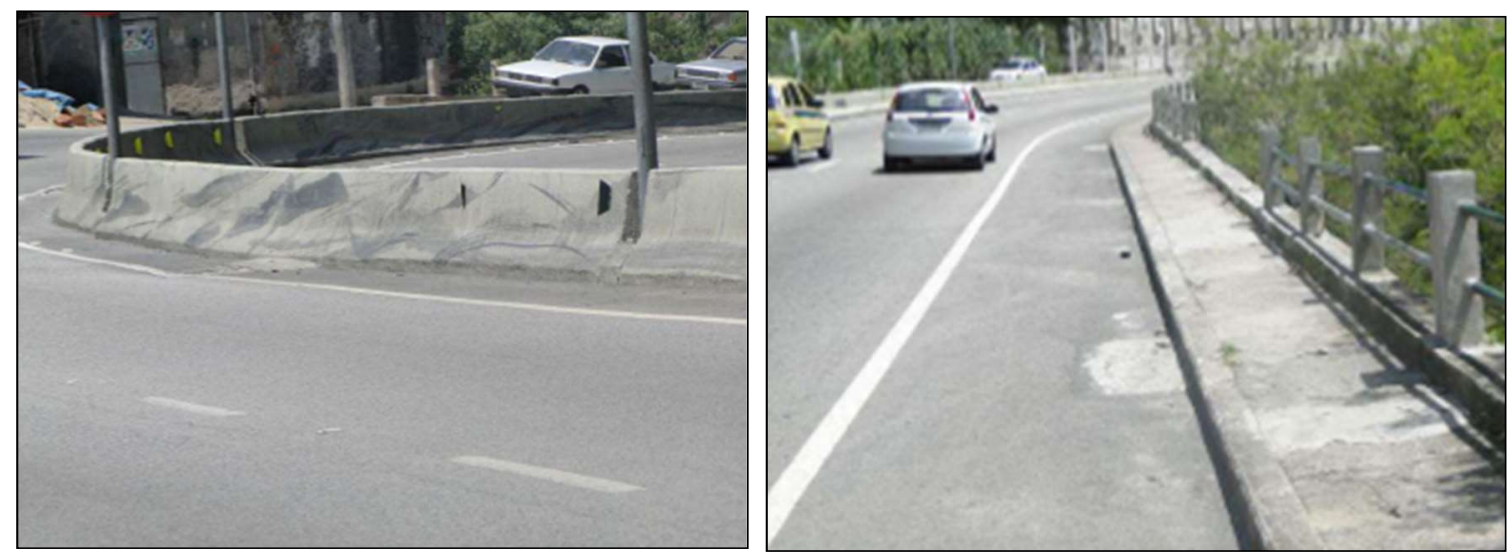

Figura 6.34: Marcas nas barreiras de concreto e danos nas barreiras longitudinais de contenção.
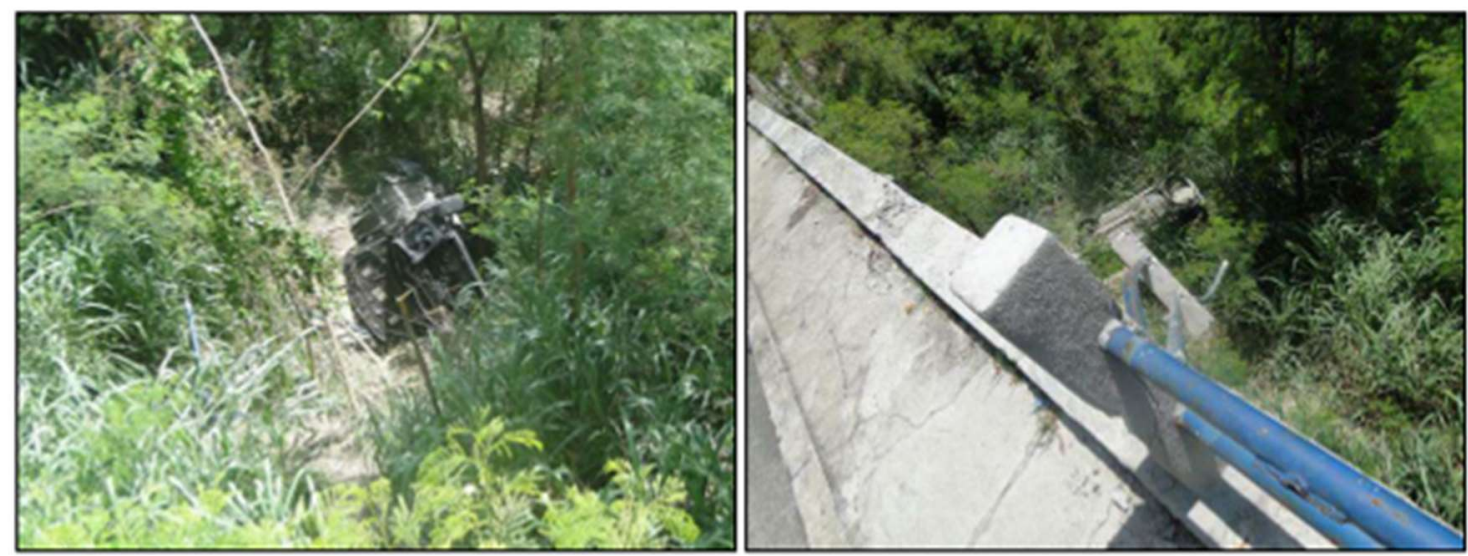

Figura 6.35: Carros envolvidos no mesmo acidente.

Algumas barreiras de contenção também se apresentavam mal-instaladas, em alguns casos com o topo delas no mesmo nível da pista, devido a obras sucessivas de recapeamento e recalques nas bordas laterais (Figura 6.36). 


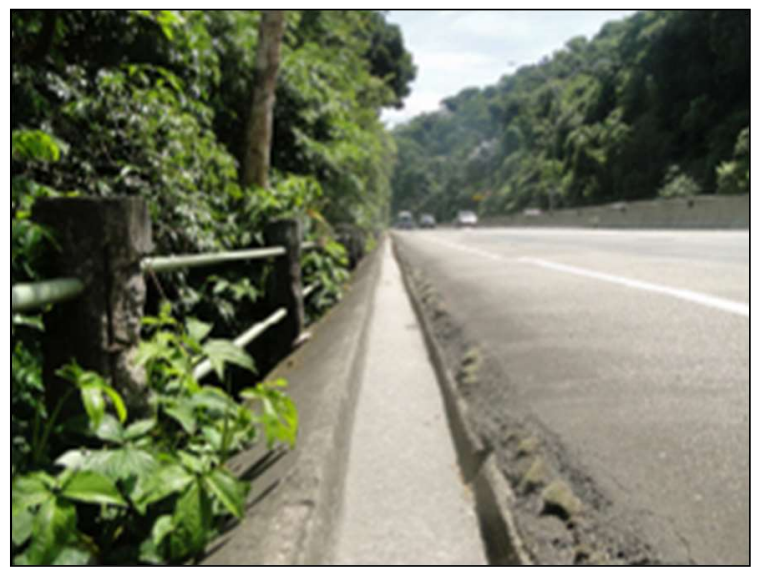

Figura 6.36: Problemas com as barreiras de contenção.

Devido a via não possuir acostamentos, qualquer veículo quebrado ou acidentado causa um congestionamento considerável, levando a uma onda de choque e potencializando outros acidentes.

\subsubsection{Pavimento}

A grande preocupação da CET-Rio, no dia da vistoria foi com relação ao pavimento da Avenida Menezes Cortes, uma vez que o trecho com SMA estava apresentando um aumento no índice de acidentes. Como o material para pavimentação neste trecho é o melhor da via, os motoristas se sentem confortáveis e seguros para acelerar e ao se deparar com as curvas da região acabam perdendo o controle da direção e saindo da pista. Porém o trecho apresenta alguns problemas de borda, o que causa desnível e potencial problema na retomada da direção pelo motorista (Figura 6.37).
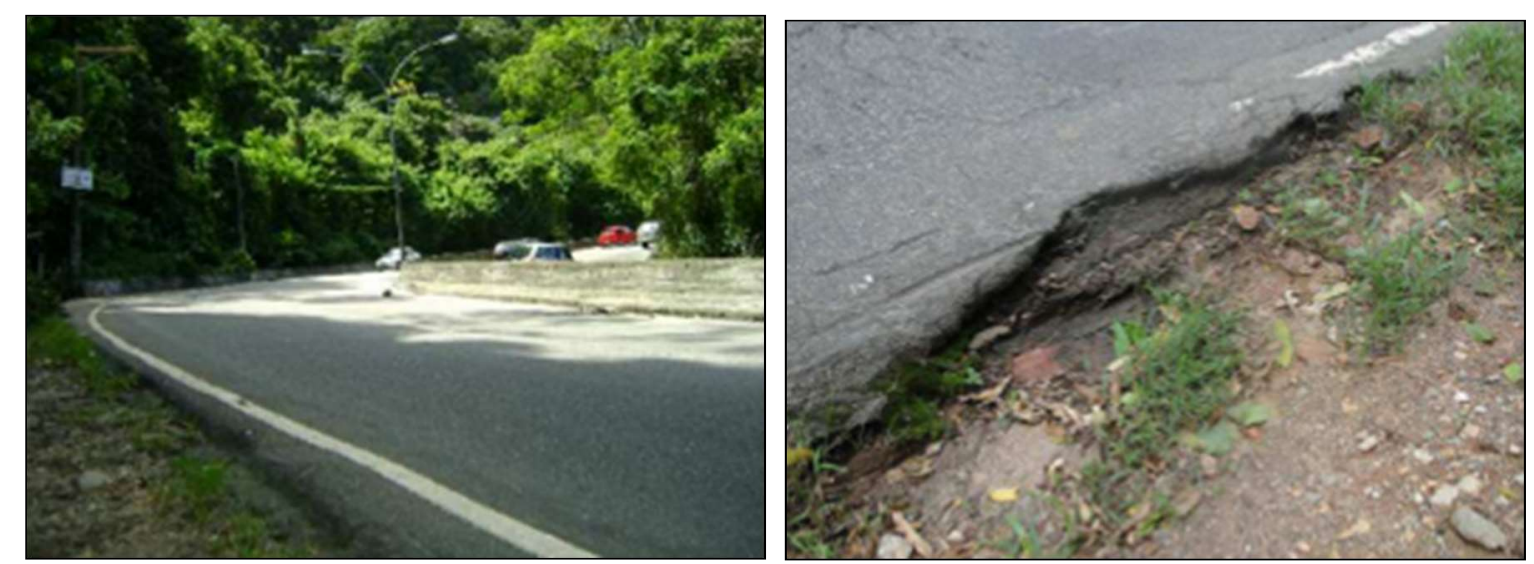

Figura 6.37: Problemas com a borda do pavimento. 
As condições de superfície do pavimento da via não são das melhores. A presença de tráfego de ônibus e caminhões, principalmente nos trechos de subida, faz com que muito diesel seja queimado e depositado em uma camada fina sobre o pavimento, que, em condições chuvosas, se torna altamente escorregadio, potencializando a perda de controle da direção. Também há um trecho com despejo de água e sabão proveniente de um lava a jato do entorno, o que deixa a via escorregadia até em dias secos e ensolarados.

\subsubsection{Sinalização}

Ressaltando que o uso incorreto ou a falta de sinalização pode levar os motoristas e pedestres a cometerem erros ou manter comportamentos incompatíveis com o que o ambiente viário pede, ocasionando acidentes de grande severidade.

A Avenida Menezes Cortes não apresenta sinalização apropriada para a indicação de curvas sinuosas. Poucas são as placas de indicativo de perigo na via salvo as placas instaladas no início das pistas, localizadas no Grajaú (Figura 6.38) e em Jacarepaguá (Figura 6.39).

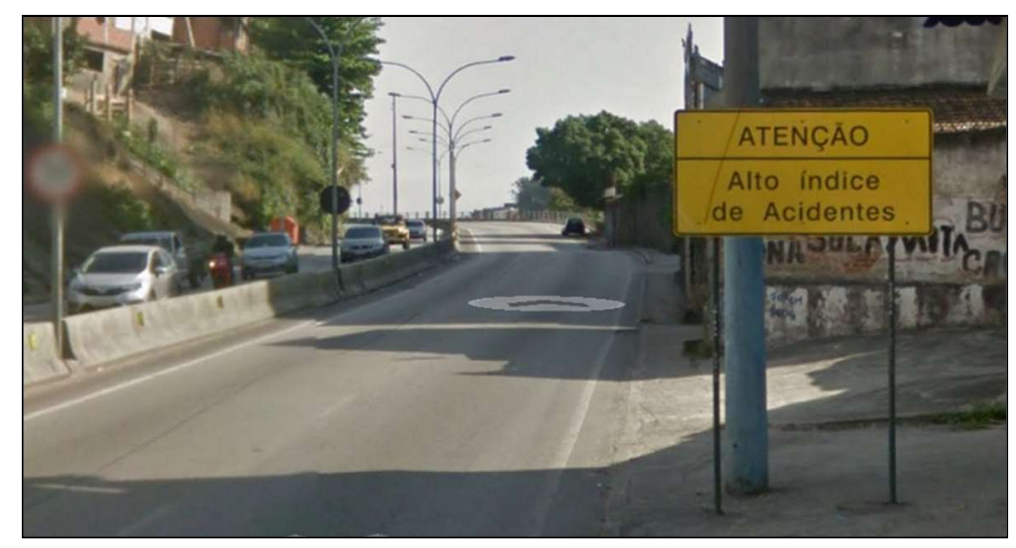

Figura 6.38: Placa de atenção localizada no bairro do Grajaú.

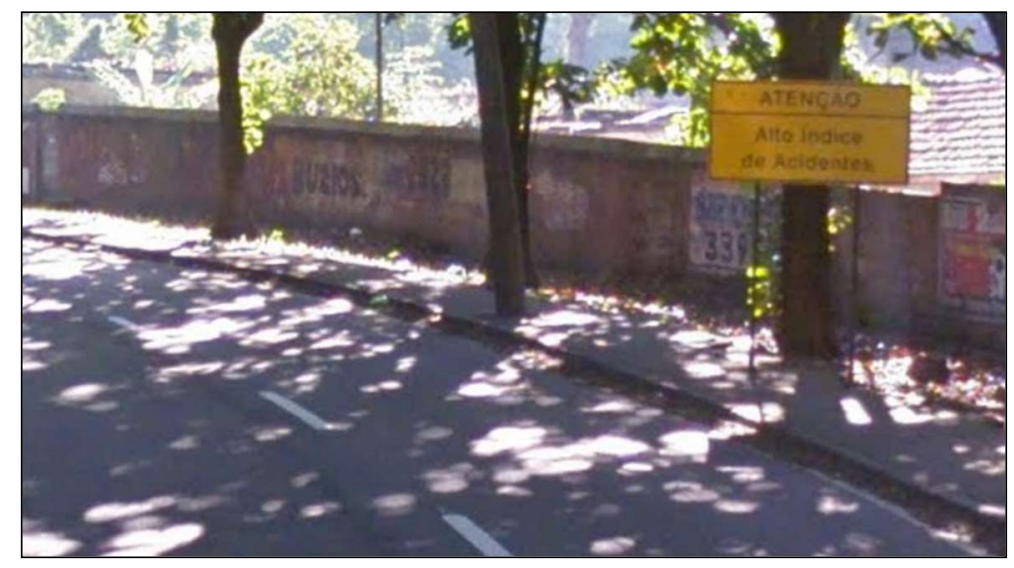

Figura 6.39: Placa de atenção localizada no bairro de Jacarepaguá. 
Com relação à sinalização horizontal, a via não apresenta pinturas diferenciadas nos trechos onde apresentam maiores índices de acidentes identificados pela CET-Rio, como a faixa contínua para proibição de mudança de faixa (LMS-1) (Figura 6.40).

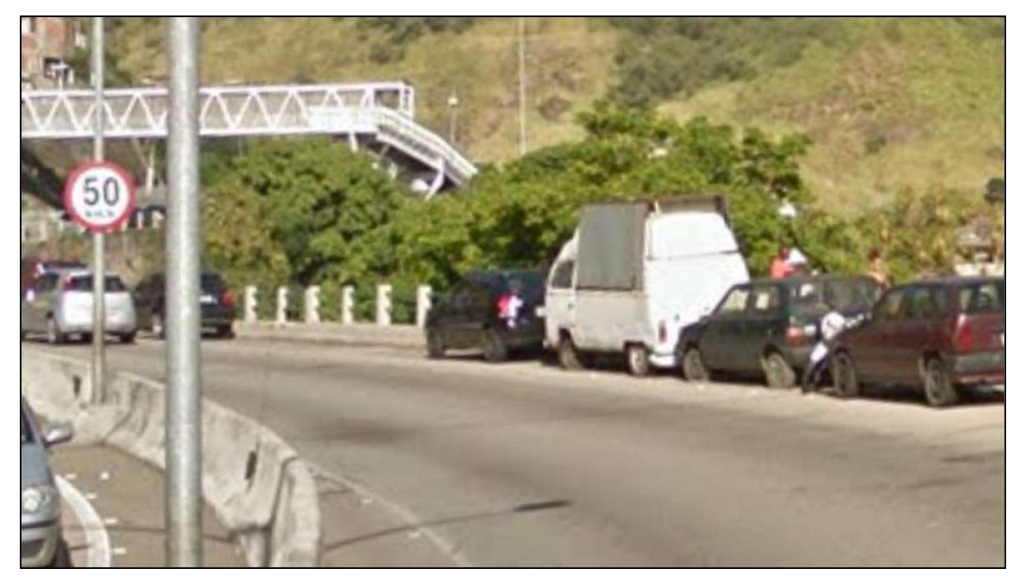

Figura 6.40: Pista da Avenida Menezes Cortes sem pintura de divisão de faixas.

\subsubsection{Interseções}

Não existe interseções no projeto da Avenida Grajaú-Jacarepaguá, porém há regiões de retornos físicos (destinados a automóveis de passeio comuns) e operacionais (destinados aos carros de socorro, ambulância e bombeiros), que também causam pontos de conflito (Figura 6.41):
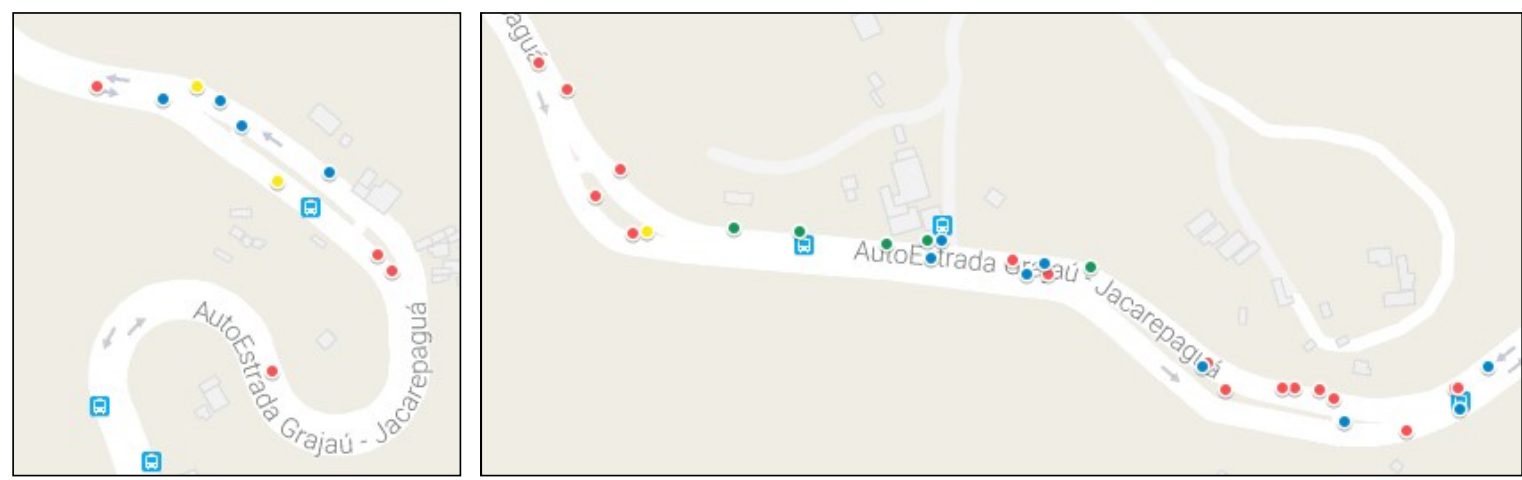

Figura 6.41: Acidentes próximos aos retornos físicos.

Muitos caminhões e carros de socorro utilizam as faixas de aceleração e desaceleração nas áreas de retorno como estacionamento, não permitindo o ganho ou perda necessária de velocidade para que os motoristas acessem a Avenida Menezes Cortes ou realizem o retorno com a velocidade desejada, fazendo com que o veículo que já trafega na via tenha de desacelerar bruscamente (Figura 6.42). 
O retorno localizado próximo ao Hospital Cardoso Fontes não apresenta boa visibilidade aos motoristas não apresenta sinalização. $\mathrm{O}$ motorista que está parado para realizar o retorno além de encontrar dificuldade na informação de como fazer o retorno, ele tem pouca distância de visibilidade para tomar a decisão de realizar ou não o retorno (Figura 6.43).
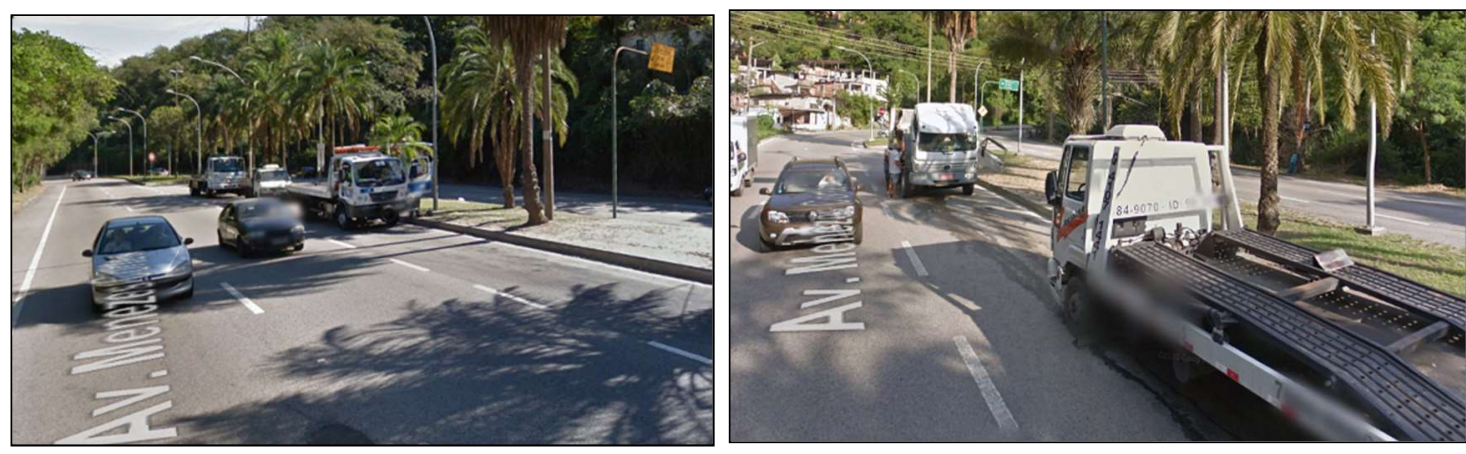

Figura 6.42: Automóveis que utilizam o retorno como estacionamento. Fonte: Google Maps (2015).
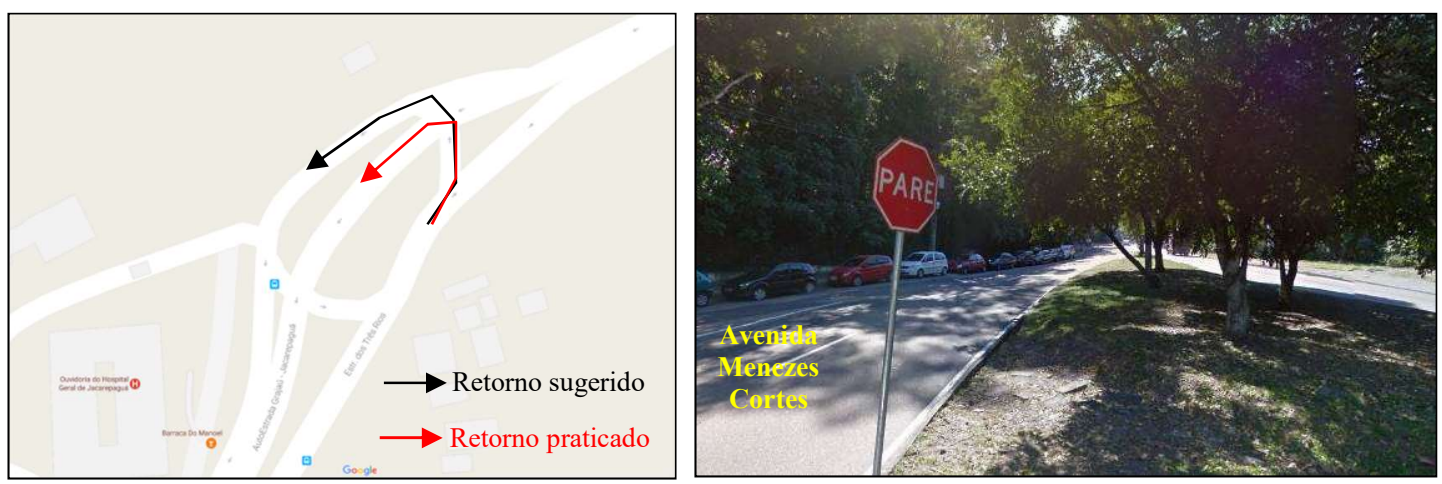

Figura 6.43: Localização e problemas de visibilidade no retorno próximo ao Hospital.

\subsubsection{Acessos e saídas}

Só existem dois acessos e duas saídas da via, uma para cada sentido, e foram estudados os acidentes em suas imediações.

$\mathrm{Na}$ entrada em Jacarepaguá, foram vizualizados inúmeros acidentes, que podem ser explicados uma vez que os motoristas saem de uma via com baixssima velocidade controlada por radar de $40 \mathrm{~km} / \mathrm{h}$, para acessar a Avenida Menezes Cortes, que não possui radar de controle de velocidade no sentido Grajaú. Essa aceleração é potencializada com o fato deste acesso ser em curva sem uma superelevação identificada pelo autor. Na saída deste bairro, 
não existem tantos acidentes obervados, pois existem dispositivos de controle de velocidade ao longo da via que sucede a Avenida (Figura 6.44):

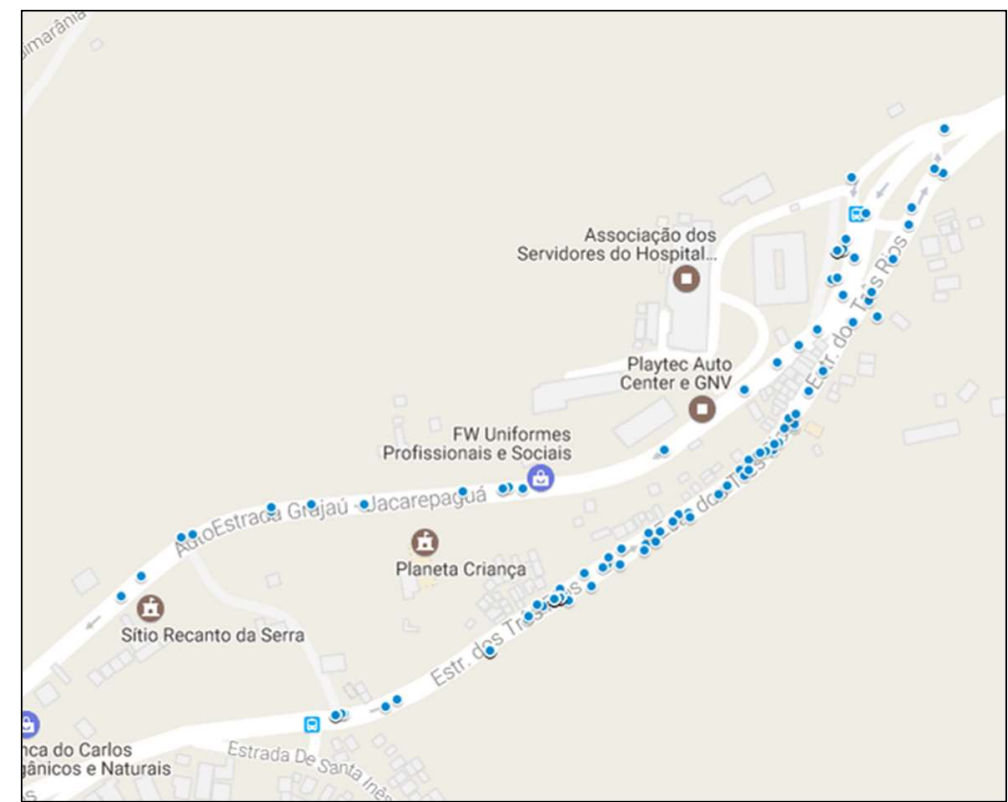

Figura 6.44: Acidentes no acesso da Avenida Menezes Cortes.

No Grajaú, o acesso se dá por meio de interseções semaforizadas, não sendo observados acidentes nesta região. Porém a saída é um fator que deve ser tomada em atenção pelas instituições, pois existe uma entrelaçamento de fluxo para veículos com a rua José do Patrocínio (Figura 6.45):

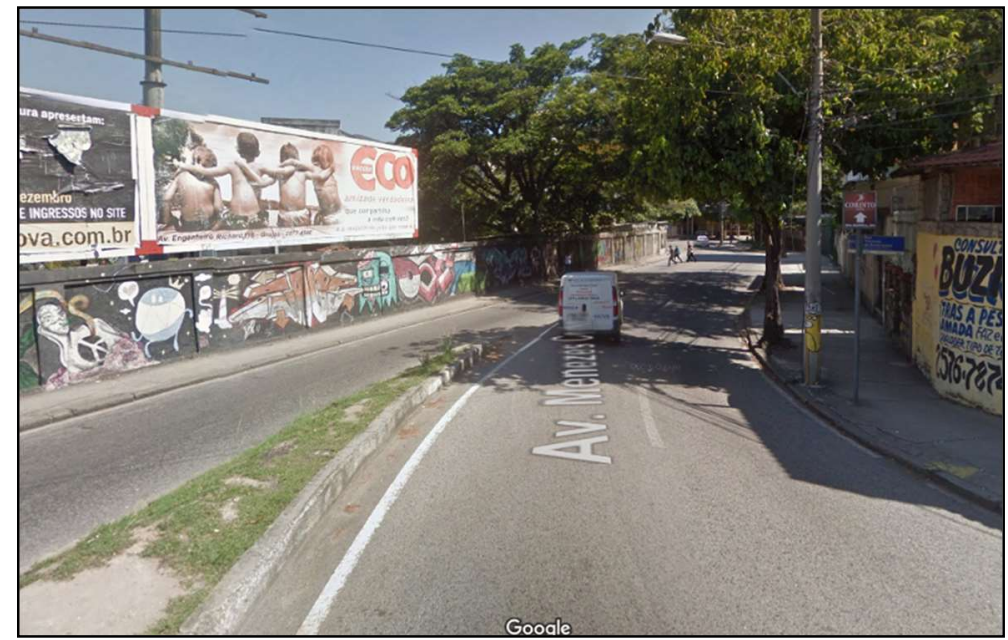

Figura 6.45: Entroncamento da Avenida Menezes Cortes com a rua José do Patrocínio. 


\subsubsection{Entorno}

A via apresenta moradias e comércios fixos próximos à pista, e acredita-se que frequentemente estes são vítimas de invasões de carros devido à perda de controle da direção dos condutores. No entanto, estas construções não apresentam dispositivos de seguranca para veículos desgovernados.

Além destes objetos fixos, também é frequente a passagem de pessoas e animais no corpo estradal, o que são elementos potenciais de perigo por que constituem eventos inesperados aos motoristas, especialmente no período noturno. São frequentes os casos de arrastões por parte na via quando há congestionamentos e os meliantes correm entre os carros em movimento como rota de fuga.

\subsubsection{Drenagem}

Para o estudo da drenagem foi analisado o relatório de 2015 do Alerta Rio como medida indireta do quanto que a chuva na via pode influenciear os acidentes. Foram utilizados os dados pluviométricos referentes à estação metereológica da Estação Estrada GrajaúJacarepaguá, localizada próximo ao Hospital Cardoso Fontes (Tabela 6.11) e os dados com os dias com precipitação maior que $1 \mathrm{~mm}$ da cidade do Rio de Janeiro e os dos bairros de Jacarepaguá e de Engenho de Dentro entre os anos de 1961 a 1990.

Tabela 6.11: Registros pluviométricos da estação Estrada Grajaú-Jacarepaguá para o período de $2010-2015$

\begin{tabular}{|c|c|c|c|c|c|c|c|c|c|c|c|c|c|c|}
\hline $\begin{array}{c}\text { Estação Pluviométrica Est. } \\
\text { Grajaú-Jacarepaguá }\end{array}$ & $J A N$ & FEV & MAR & $A B R$ & MAI & $J U N$ & $J U L$ & $A G O$ & SET & OUT & NOV & $D E Z$ & $\begin{array}{r}\text { TOTAL } \\
\text { ANUAL }\end{array}$ & $\begin{array}{l}\text { MÉDIA } \\
\text { ANUAL }\end{array}$ \\
\hline Média 2010-2014 & & 46,4 & 164,6 & 136,1 & 85,2 & & & 36,8 & 66,8 & 92,5 & 97,6 & 175 & 1256,9 & 104,7 \\
\hline 2015 & 62,2 & 134 & 138,4 & 71,2 & 47,6 & 107,4 & 26,6 & 7,2 & 90 & 27,4 & 121,8 & 61,4 & 895,2 & 74,6 \\
\hline Média 2010-2015 & 177,5 & 63,9 & 159,4 & 123,1 & 77,7 & 76,4 & 70,1 & 30,9 & 71,4 & 79,5 & 102,4 & 152,3 & 1184,6 & 98,7 \\
\hline
\end{tabular}

Fonte: adaptado de Alerta Rio (2016).

Tabela 6.12: Dias com precipitação maior que $1 \mathrm{~mm}$ em cada estação

\begin{tabular}{cccccccccccccc}
\hline Nome da Estação & $\boldsymbol{J A N}$ & $\boldsymbol{F E V}$ & $\boldsymbol{M A R}$ & $\boldsymbol{A B R}$ & $\boldsymbol{M A I}$ & $\boldsymbol{J U} \boldsymbol{N}$ & $\boldsymbol{J U L}$ & $\boldsymbol{A G O}$ & $\boldsymbol{S E T}$ & $\boldsymbol{O U} \boldsymbol{T}$ & $\boldsymbol{N O \boldsymbol { V }}$ & $\boldsymbol{D E Z}$ & $\boldsymbol{A N O}$ \\
\hline Rio de Janeiro & 11 & 7 & 8 & 9 & 6 & 6 & 4 & 5 & 7 & 9 & 10 & 11 & 93 \\
Jacarepaguá & 12 & 9 & 9 & 9 & 8 & 6 & 5 & 5 & 7 & 11 & 11 & 13 & 105 \\
Engenho de Dentro & 12 & 10 & 9 & 8 & 8 & 5 & 5 & 5 & 7 & 10 & 11 & 12 & 102 \\
\hline
\end{tabular}

Fonte: adaptado de INMET (2014).

Observando os dados da Tabela 6.11 e da Tabela 6.12, é possível visualizar que os meses de novembro a abril apresentam índices pluviométricos acima da média enquanto os meses de maio a setembro apresentam índices menores, o que de certa forma é esperado, já que o 
clima da cidade do Rio de Janeiro é caracterizado como tropical atlântico, com verões quentes e úmidos e invernos secos.

Tabela 6.13: Número de acidentes da Avenida Menezes Cortes por mês

\begin{tabular}{cccccccccccccc}
\hline Nome da Via & $\boldsymbol{J A N}$ & $\boldsymbol{F E V}$ & $\boldsymbol{M A R}$ & $\boldsymbol{A B R}$ & $\boldsymbol{M A I}$ & $\boldsymbol{J U N}$ & $\boldsymbol{J U L}$ & $\boldsymbol{A G O}$ & $\boldsymbol{S E T}$ & $\boldsymbol{O U U T}$ & $\boldsymbol{N O \boldsymbol { V }}$ & $\boldsymbol{D E Z}$ & $\boldsymbol{A N O}$ \\
\hline Av. Menezes Cortes & 47 & 24 & 51 & 38 & 37 & 44 & 30 & 19 & 22 & 31 & 33 & 25 & 401 \\
\hline
\end{tabular}

A Figura 6.46 apresenta gráficos relacionando os dados da Tabela 6.11 com o número de acidentes por mês da Tabela 6.13, é possível observar que o número de acidentes é altamente relacionado às média mensais de chuvas da estação Estrada Grajaú-Jacarepaguá, tendo coeficientes de correlação de 0,85. Quando os dados são comparados apenas ao ano de 2015, essa correspondência não é vista, pois 2015 foi um ano atípico com relação às chuvas devido ao fenômeno climático El Niño. Foram retirados os dados de dezembro e de junho da análise, pois eles são meses iniciais de férias escolares e apresentam grandes inconsistências no estudo de tráfego.

A Figura 6.47 correlaciona dados da Tabela 6.12 com os dados Tabela 6.13. Não existe uma correlação muito boa dos números de dias com o número de acidentes, os coeficientes de relação variam de 0,26 a 0,31 . Porém é possível observar que a maior correlação foi com a estação mais próxima ao da Estrada Grajaú Jacarepaguá, podendo mostrar algum indício da correlação das chuvas com o número de acidentes na via.

Outro fator a ser destacado no estudo da drenagem com o número de acidentes, são as questões pontuais. Em um ponto de declive da via, a caixa de coleta de água pluvial não se encontra no nível mais baixo da pista e, com isso, muita água passa pelo ponto sem ser coletada e, ao descer logo mais, encontra uma curva com superelevação e a água de toda a pista passa de um lado para o outro da via, potencializando derrapagens (Figura 6.48).

Além disso, alguns dispositivos de drenagem foram limpos dias antes da vistoria, porém o lixo não foi devidamente coletado podendo retornar ao sistema de drenagem na próxima chuva, podendo entupir e deixar vazar para a pista a água coletada, sendo um fator que pode aumentar o número de derrapagens no ponto (Figura 6.49): 

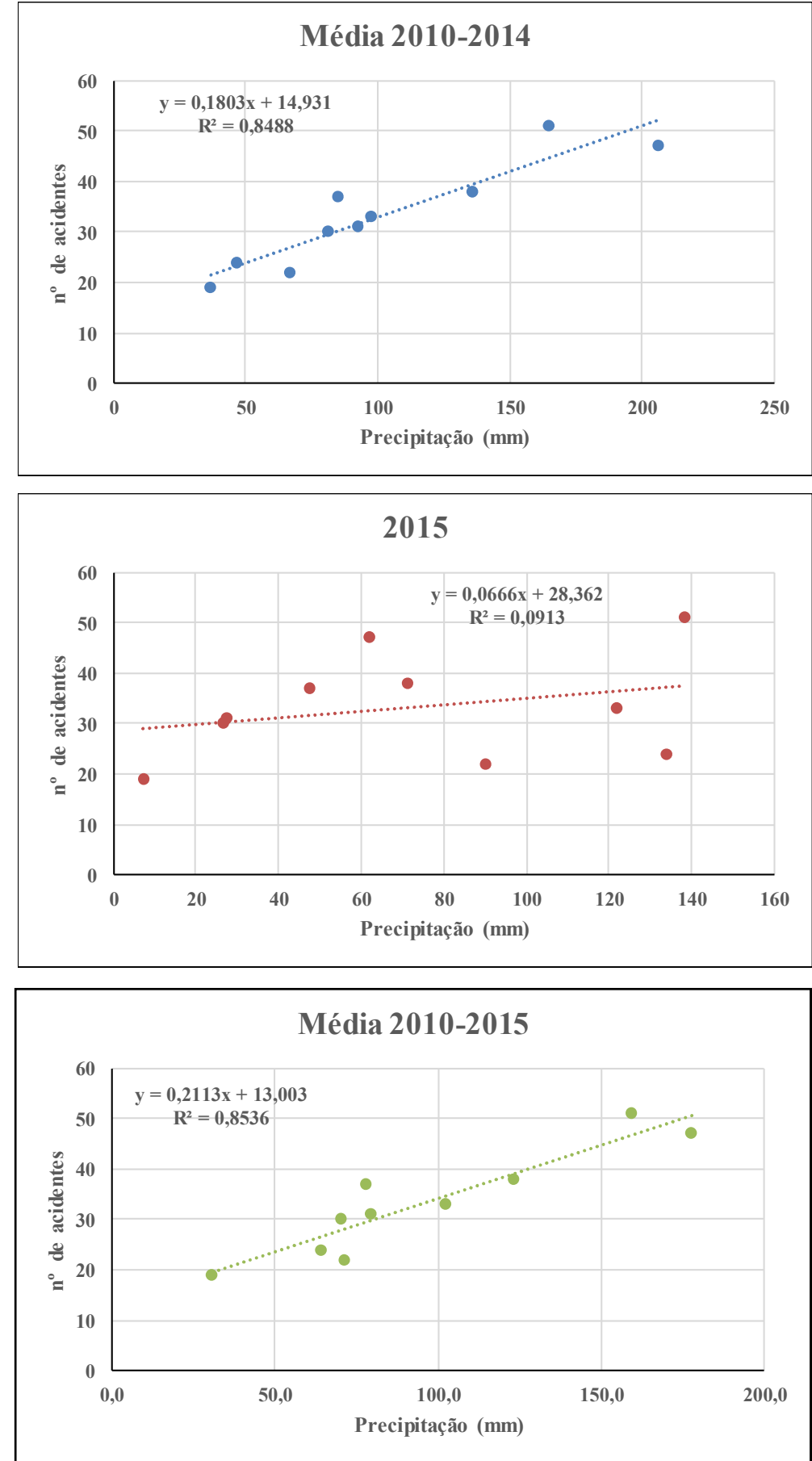

Figura 6.46: Relação da precipitação mensal com o número de acidentes. 

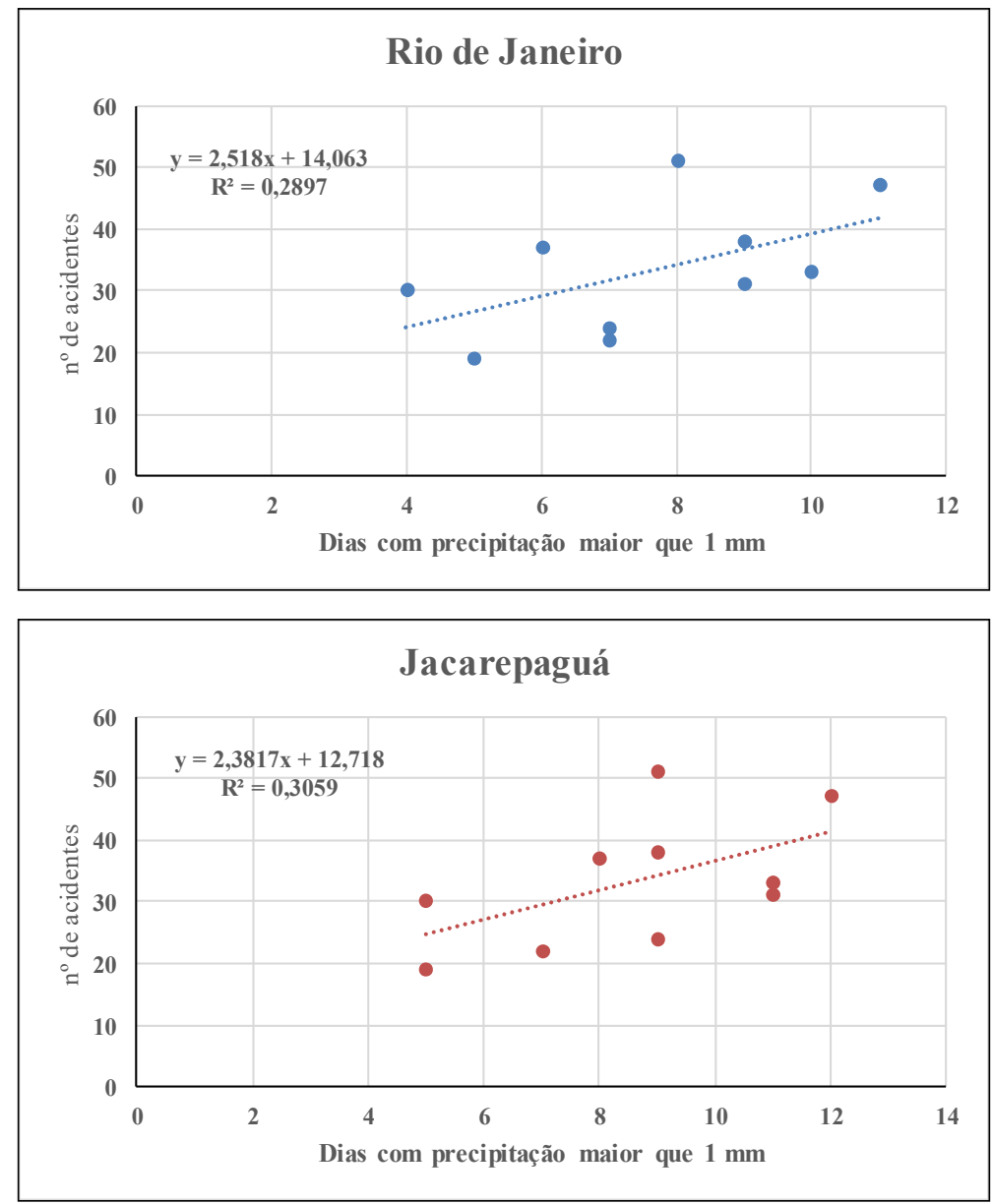

\section{Engenho de Dentro}

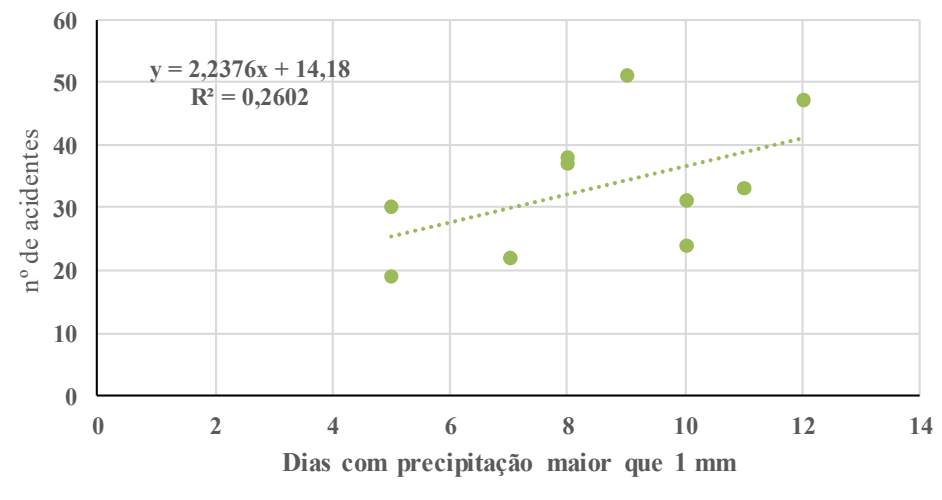

Figura 6.47: Relação do número de dias com precipitação maior que $1 \mathrm{~mm}$ com o número de acidentes. 

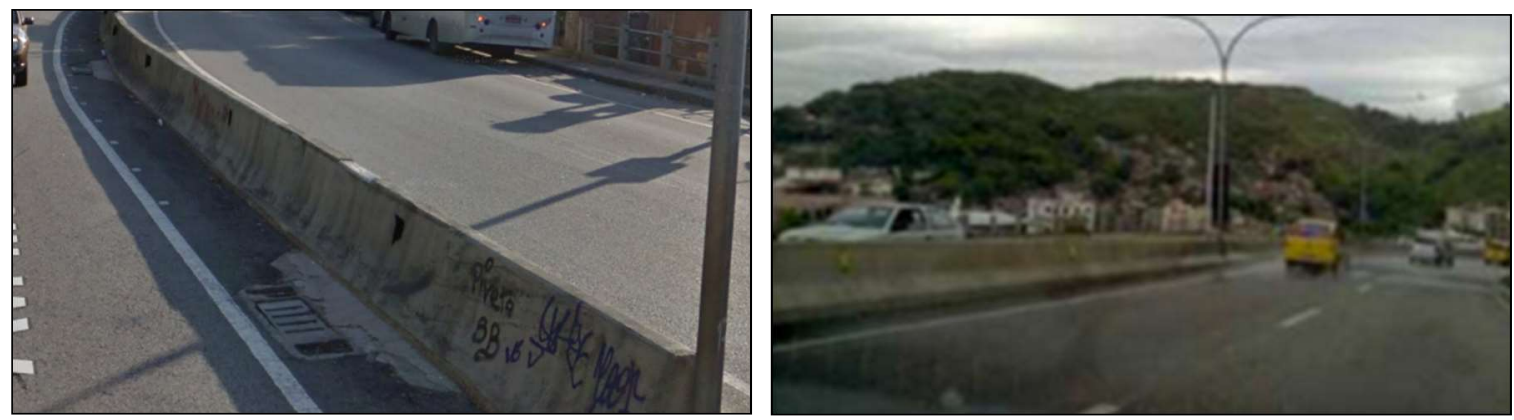

Figura 6.48: Problemas de projeto com dispositivos de drenagem.
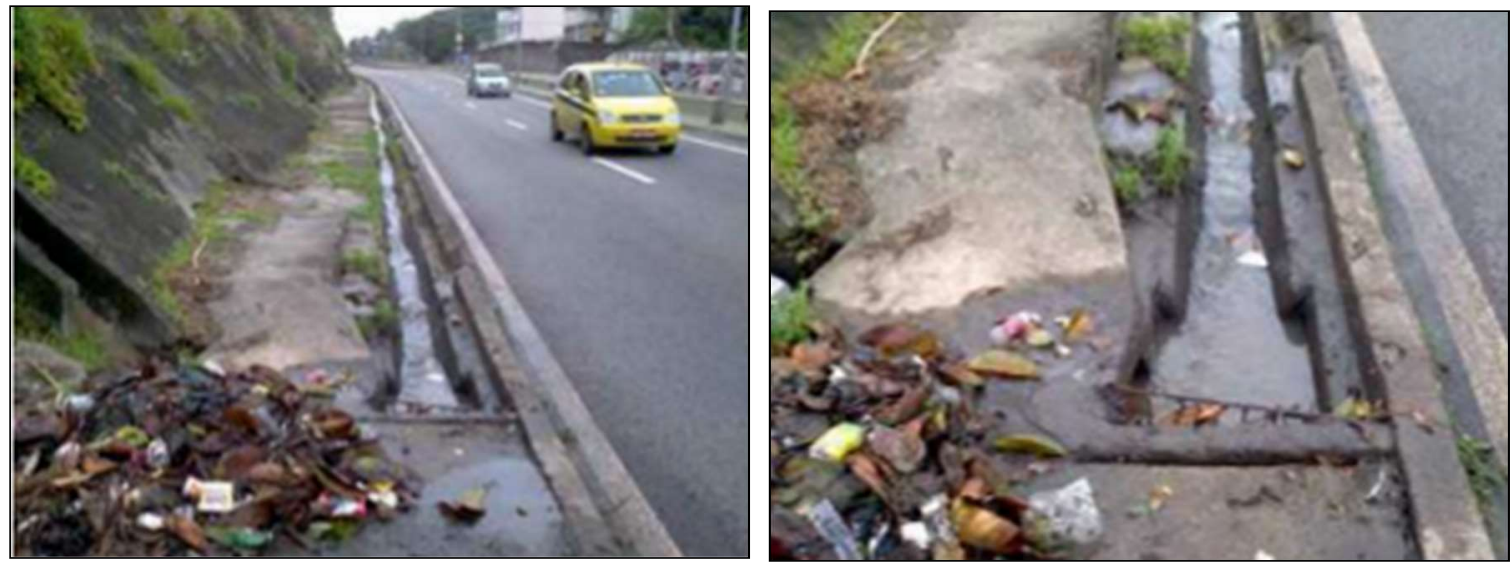

Figura 6.49: Lixo espalhado que não foi coletado próximo ao dispositivo de drenagem.

\subsubsection{Iluminação}

A via se apresenta bem iluminada no período noturno. Porém não é descartado o fator iluminação na ocorrência dos acidentes, pois não existe um histórico dos acidentes sobre as condições da via, para elaboração de um relatório que possa eliminar a influência da iluminacao da via nos acidentes.

\subsubsection{Travessias para pedestres}

Apesar de existirem três travessias em desnível, consideradas as mais efetivas sob o ponto de vista da segurança, na Avenida Menezes Cortes, os moradores locais não as utilizam e atravessam pela pista, e não são raros os casos de atropelamento nas proximidades das passarelas (Figura 6.50). 


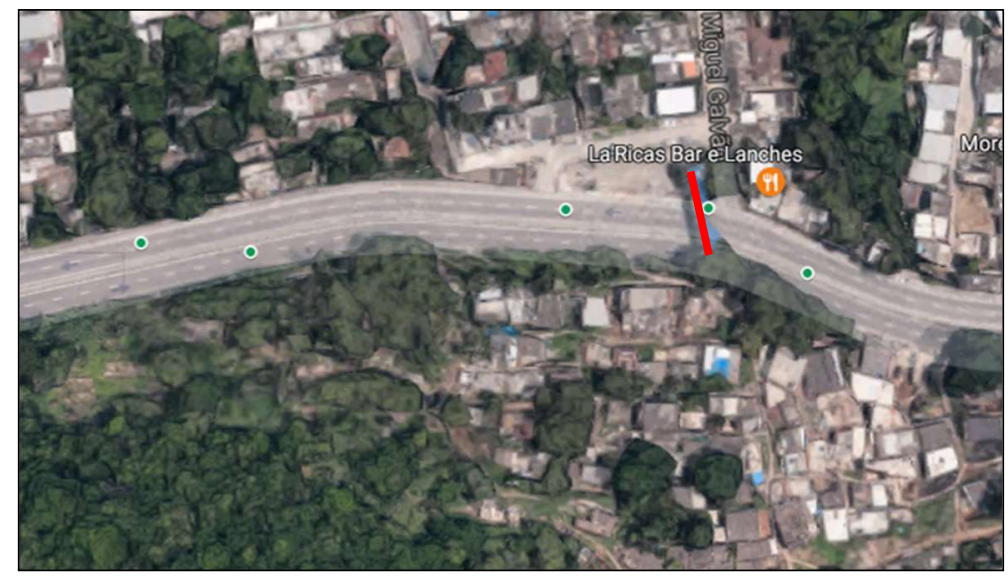

Figura 6.50: Casos de atropelamento (pontos verdes) próximos à passarela (traço vermelho) na Avenida Menezes Cortes.

\subsubsection{Dispositivos de controle de tráfego}

Foram instalados quatro dispositivos de controle de velocidade, todos no sentido Jacarepaguá, após o início deste estudo e já se observam reduções consideráveis de número de acidentes nesses pontos. Porém não existem ainda as estatísticas dos acidentes após a instalação destes radares.

\subsubsection{Publicidade}

A Avenida Menezes Cortes é uma via que possui muitas curvas, o que exige muita concentração por parte do motorista e a presença de outdoors (Figura 6.51) e de letreiros dos comércios do entorno (Figura 6.52) retiram a concentração do condutor, especialmente na área de concentração demográfica.

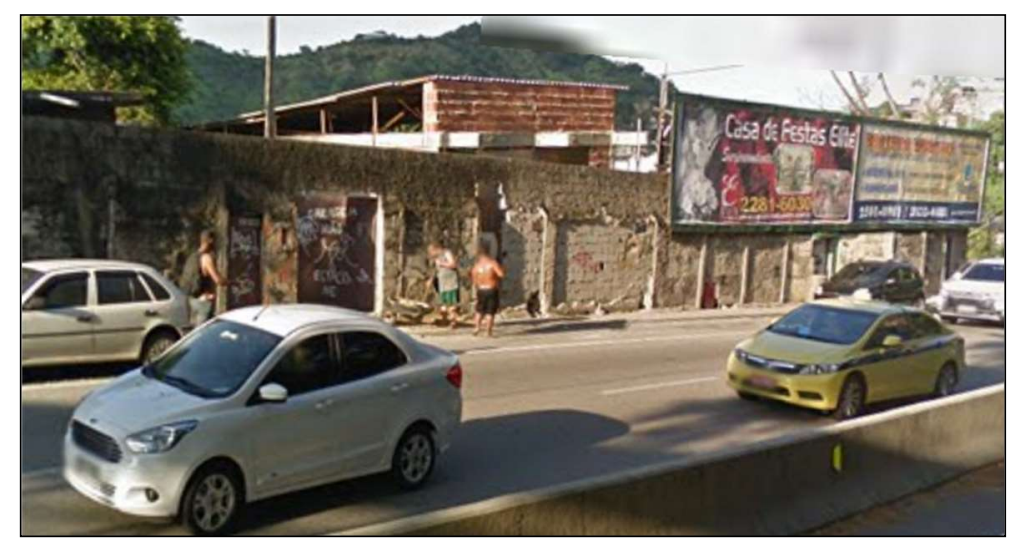

Figura 6.51: Outdoors na Avenida Menezes Cortes. 


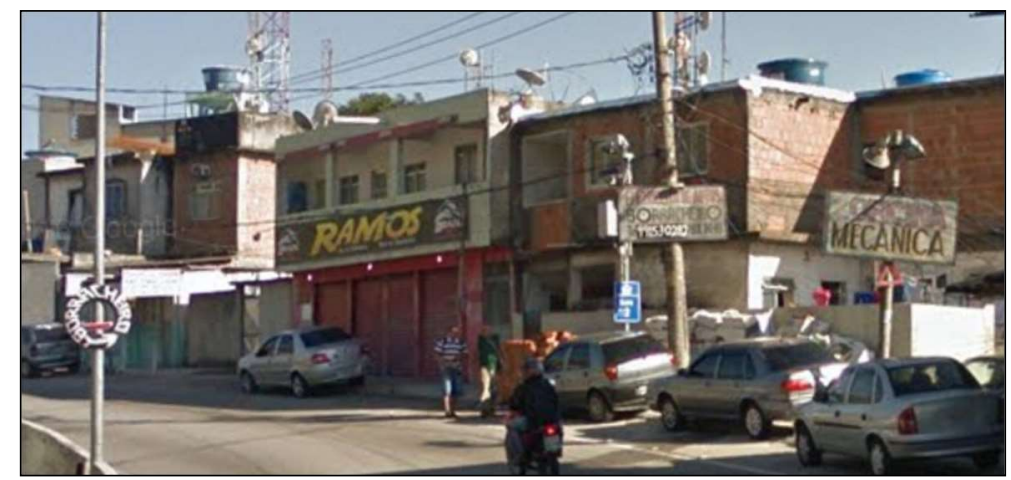

Figura 6.52: Letreiros de comércios próximos à Avenida Menezes Cortes.

\subsubsection{Estacionamento}

A lateral da via é utilizada como estacionamento pelos moradores e para quem quer utlilizar o comércio local no trecho de ida para Jacarepaguá. Porém, o motorista que realiza tal ato, primeiramente, reduz a velocidade para conseguir atenção em conseguir uma vaga, causando um diferencial de velocidade que é sentido pelo motorista que o sucede e dá início a uma manobra de ultrapassagem. Além de causar esse imbóglio, o carro ocupa um espaço emergencial que deveria ser ocupado por um veículo fora de operações.

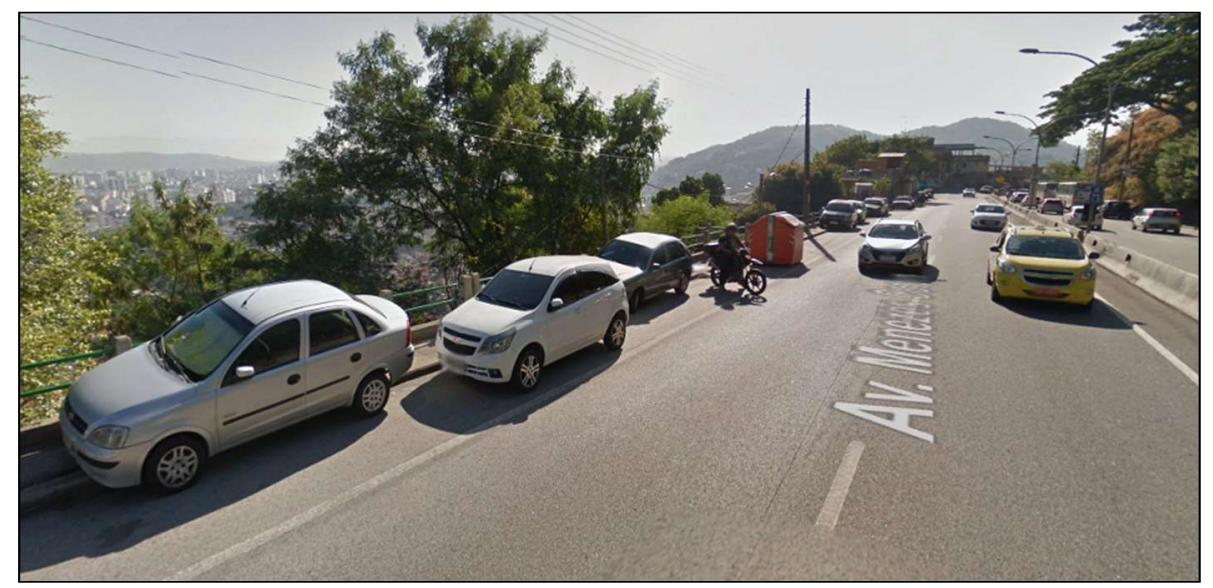

Figura 6.53: Estacionamento irregular ao longo da Avenida Menezes Cortes.

Vale lembrar que veículos também estacionam nas faixas de aceleração e desaceleração dos retornos como já comentado no item 6.9.5.

\subsubsection{Congestionamento}

A Figura 6.54 apresenta o gráfico com acidentes ao longo das horas do dia. As demarcações vermelhas são as horas-pico da manhã e da tarde. Pode-se ver que a hora-pico da manhã apresenta um maior número de acidentes do que a tarde, uma vez que pela manhã o movimento de pessoas é bem mais concentrado devido a hora de compromisso de trabalho 
ou escola. Já pela tarde a concentração de pessoas voltando para casa é mais distribuída, uma vez que as pessoas realizam outros compromissos ao longo do trabalho, o que ajuda a diminuir o fluxo de veículos na via nessa faixa de horarío.

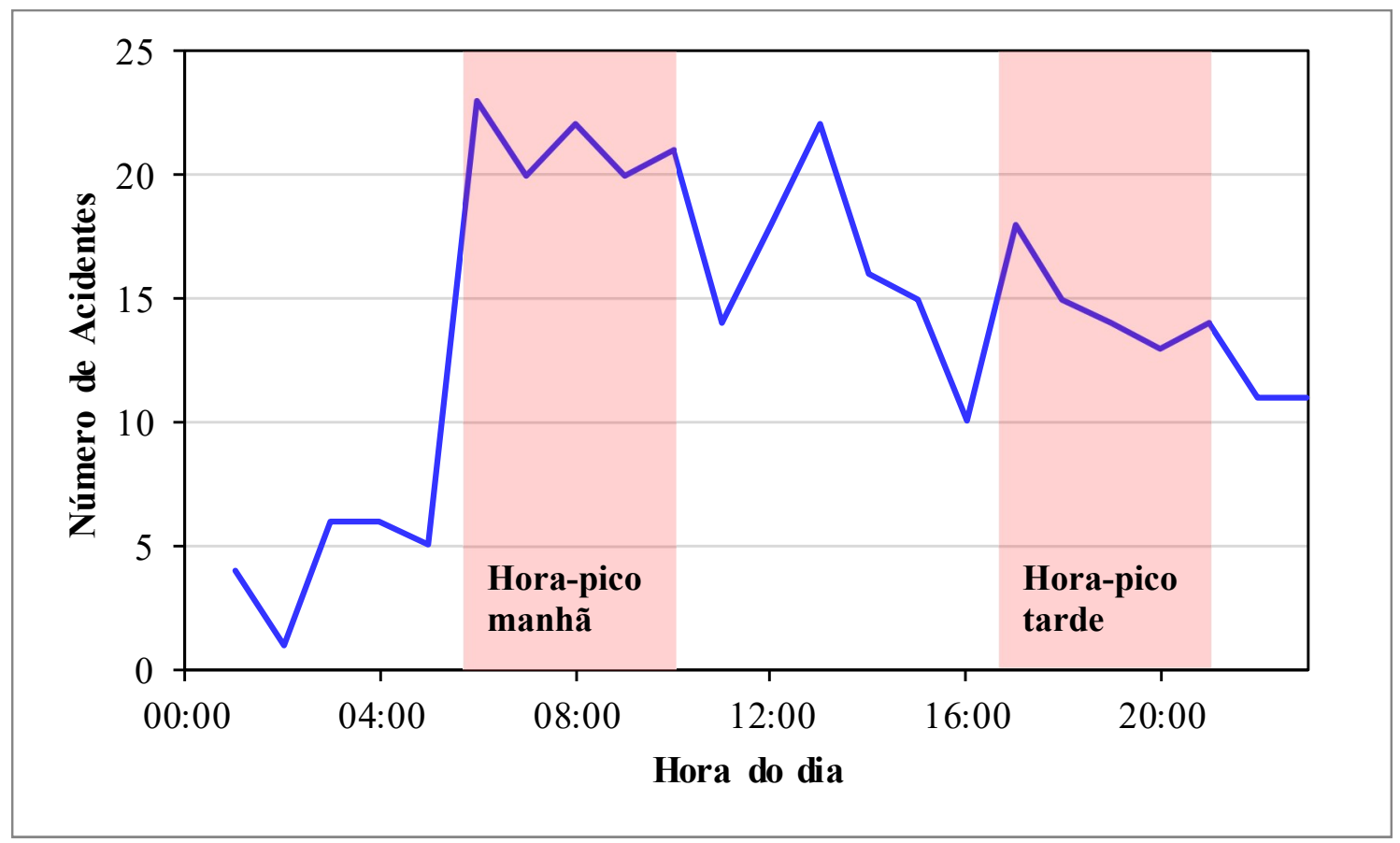

Figura 6.54: Número de acidentes ao longo das horas do dia e marcação das horas-pico.

\subsubsection{Velocidade}

O estudo de velocidade tabém foi incluído no cálculo do ICG e foi abordado no item 6.9.1. É importante salientar que mudanças bruscas de velocidade, seja em módulo, direção, ou sentido, podem ocasionar acidentes sérios. Tais alterações acontecem na via nas curvas fechadas, em locais onde o entorno se encontra com bastante movimento de pedestres, nas imediações dos retornos e em tudo o que foi descrito nos itens até aqui.

\subsubsection{Vegetação}

A lista de procedimentos discriminada no item 3.16, que FHWA (2008a) sugere para controle de vegetação não vem sendo realizada no entorno na Avenida Menezes Cortes. A vegetação marginal é de Mata Atlântica e têm crescimento rápido, o que, muitas vezes, dificulta a passagem de pedestres e a visibilidade dos motoristas, principalmente nas áreas das curvas, fazendo com que a necessidade de manutenção seja frequente. A Figura 6.55, a Figura 6.56, a Figura 6.57, e a Figura 6.58 mostram alguns problemas da via no que se refere a vegetação. 
Vale ressaltar que quase metade da via passa por um parque nacional. Por essa razão, o corte de árvores e poda da vegetação pode esbarrar em questões ambientais, tema que o presente estudo não aborda.

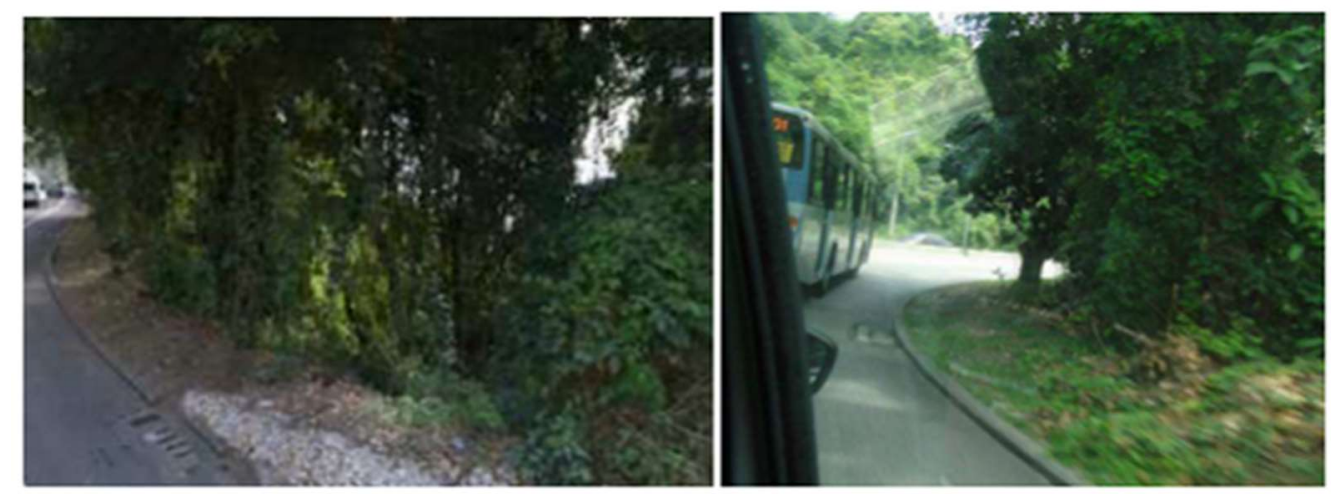

Figura 6.55: Visibilidade da via comprometida pela vegetação.
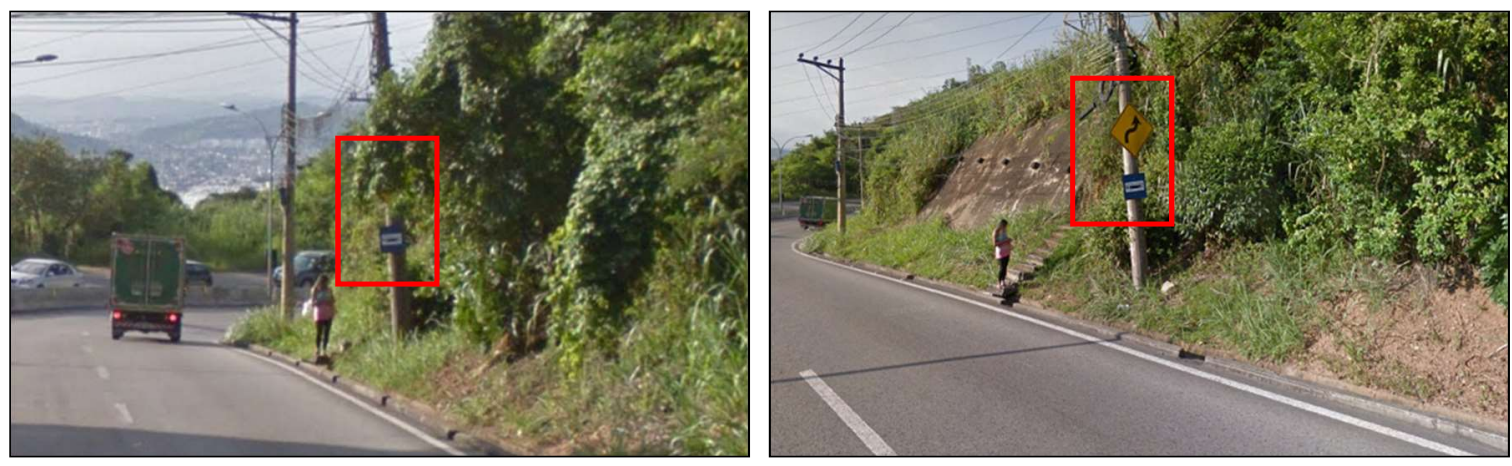

Figura 6.56: Placa escondida pela vegetação na Avenida Menezes Cortes.

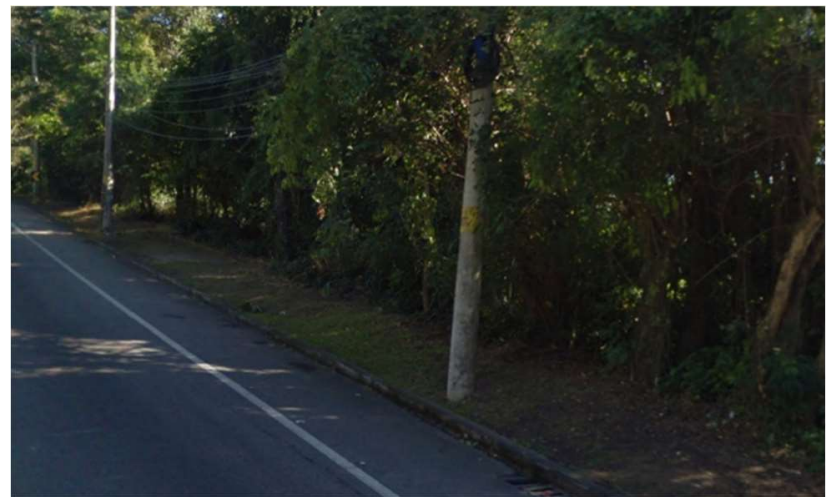

Figura 6.57: Calçada tomada por vegetação. 


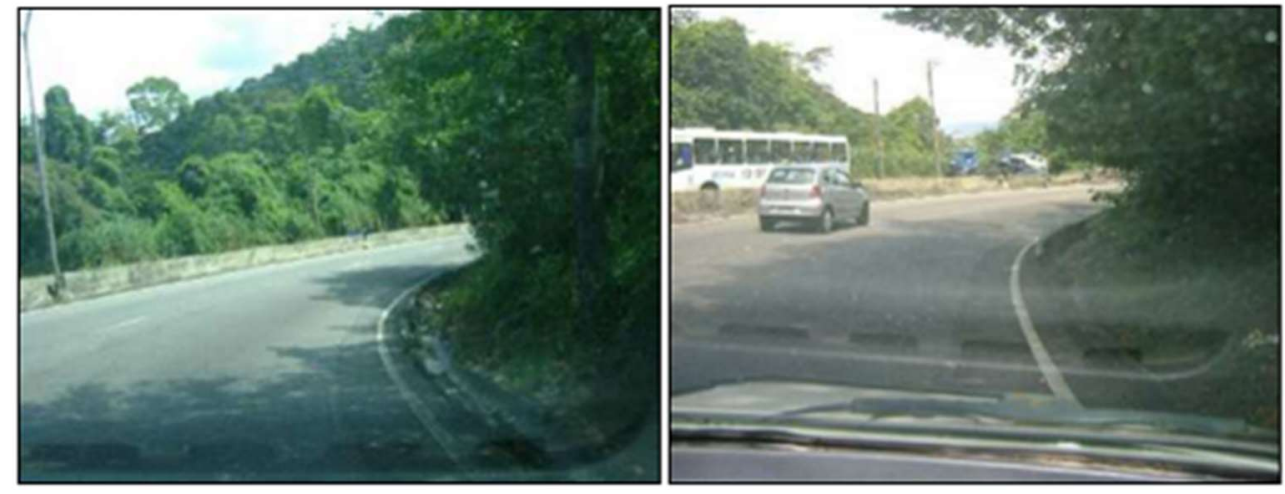

Figura 6.58: Visibilidade e drenagem da via comprometidas pela vegetação. 


\section{CONCLUSÕES E SUGESTÕES PARA TRABALHOS FUTUROS}

Os acidentes de trânsito são um grande desafio aos governos e autoridades de segurança, pois, em muitos casos, podem gerar mortes e lesões irreversíveis e, assim, causar um grande impacto sobre a economia dos países. A motivação e os benefícios potenciais para eliminar ou mitigar os acidentes de trânsito estão relacionados à intervenção viária. Contudo, muitos acidentes encontram-se associados ao fator humano.

Inicialmente, neste trabalho, são apresentadas as vantagens decorrentes da adoção de ações baseadas no gerenciamento de riscos e no tratamento preventivo da segurança viária. Essas medidas priorizam atuações sobre veículos e, em especial, sobre o esquema viário como alternativa viável para reduzir o peso do fator humano nos acidentes.

Para responder à questão 1 deste trabalho: "Como as características físicas e operacionais das rodovias e vias urbanas se relacionam com a segurança de tráfego?", foram reunidas pesquisas desenvolvidas e publicadas por vários pesquisadores, que mostram que acidentes são eventos de natureza complexa, para os quais podem contribuir de maneira simultânea diversos fatores associados aos componentes humano, viário-ambiental e veicular. Ainda que diferentes estudos tenham como foco principal o comportamento humano, ressalta-se a importância de avaliar e de tratar aspectos relacionados ao veículo e à via, para conseguir análises e soluções mais eficazes na melhoria das condições de segurança. Foram identificadas e correlacionadas, em uma ordem de importância estabelecida pelo autor, com os acidentes de trânsito, as seguintes características viárias:

- Consistência do traçado da via: O projeto geométrico da via, se mal desenvolvido, pode levar a momentos de aceleração e desaceleração dos motoristas, gerando momentos de confusão e indecisão, que podem levar a conflitos;

- Drenagem: $\mathrm{O}$ acúmulo de água nas vias pode gerar transtornos, pois contribui para a formação de uma película d'água, causando o efeito de aquaplanagem, com perda da aderência necessária à segurança. A água também possui a capacidade de infiltrar e enfraquecer a estrutura, resultando desde o colapso do pavimento até a formação de trincas e buracos;

- Pavimento: o tipo de pavimento e, principalmente, as condições de sua superfície são essenciais na garantia da segurança e do conforto dos usuários do sistema de trânsito; 
- Seção transversal: As características da seção transversal, (número de faixas, canteiro central, barreiras de contenção, acostamentos, calçadas e faixas auxiliares), estão relacionadas à fluidez do tráfego e, por conseguinte, às questões de diferenciais de velocidade que influenciam a formação de acidentes;

- Situação do entorno: As condições das áreas adjacentes à via influenciam tanto a quantidade, quanto a gravidade dos acidentes. Sendo assim, destaca-se a importância de se oferecer uma maior segurança aos possíveis veículos desgovernados por meio de ações que visam uma segregação das áreas adjacentes e ao gerenciamento dos obstáculos perigosos;

- Manutenção da vegetação: Outra potencial causa para os acidentes é a vegetação, pois o crescimento rápido de arbustos e galhos de árvores podem limitar ou dificultar a visão, pelos motoristas, dos dispositivos de sinalização e controle de tráfego;

- Travessias para pedestres: Representam os locais onde ocorrem os maiores riscos de acidentes decorrentes da interação de forma mais direta entre pedestre e veículos;

- Presença de interseções: Um grande número de conflitos e de acidentes ocorre nas interseções, principalmente nas áreas urbanas, sendo que nos cruzamentos considerados como pontos de maior periculosidade na rede viária, acidentes mais comuns são os abalroamentos transversais e os atropelamentos, tanto de pedestres, como de ciclistas;

- Acessos e saídas: Existe uma estreita relação entre as taxas de acidentes e os níveis de controle de acesso de rodovias, sendo que a eliminação da variedade e do tipo de espaçamento dos acessos constitui uma das medidas de influência no número de acidentes de trânsito, pois reduz os eventos inesperados e os pontos de decisão;

- Sinalização: Deve ser projetada e localizada a fim de conquistar a atenção do motorista, permitindo-lhe um tempo de reação adequado, auxiliando na compreensão, não só das mensagens transmitidas como também de sua importância para a segurança das viagens;

- Iluminação: Em vias ou locais onde há falta de postes de iluminação, a visibilidade e a capacidade dos motoristas de identificação precisa de obstáculos como por exemplo a presença de pedestres, acarretando na vulnerabilidade dos andarilhos. A iluminação reduz acidentes como atropelamentos e colisões, tanto em número como a severidade; 
- Dispositivos de controle de tráfego: A programação do tempo de ciclo e a sincronização dos semáforos afetam a fluidez no trânsito, além de fazer com que os motoristas adotem comportamento de risco ou até mesmo ignorem a indicação estabelecida, já que ao buscarem conforto e economia do tempo, eles possibilitam comprometer a segurança dos usuários. $\mathrm{O}$ uso de radares e de lombadas eletrônicas tem demonstrado efeito positivo no aumento da segurança de motoristas e pedestres, por meio do controle e da redução da velocidade na circulação dos veículos;

- Publicidade: Os elementos de publicidade podem provocar a distração dos motoristas e dos pedestres. Num ambiente onde há excesso de elementos publicitários, há, também, o conflito entre a atenção do motorista na via e a distração com a publicidade. No entanto, também se acredita que a publicidade estimule o condutor sob condições que não solicitam um grande desempenho do motorista, como, por exemplo, quando há uniformidade do pavimento e da geometria, baixo volume de veículos e poucas interseções;

- Velocidade da via: A relação entre velocidade e segurança deve ser abordada em três aspectos: uma primeira abordagem, considerando que a capacidade do indivíduo na percepção e processamento de informações sobre situações perigosas diminui ao se aumentar a velocidade de circulação; a segunda assume que a probabilidade de um motorista se envolver em um acidente é função da diferença entre sua velocidade individual e a velocidade dos outros motoristas; a terceira está a associada à percepção do risco do motorista e considera que, ao elevarem as velocidades, os motoristas não necessariamente aumentam o risco de se envolver em acidentes.

A consistência do alinhamento vertical e horizontal e a drenagem são as características que mais influenciam o número e a severidade de acidentes, uma vez que eles influenciam diretamente a perda de controle do automóvel pelo motorista. Apesar da velocidade não possuir uma relação menor com os acidentes do que em relação às outras características, foi colocada em último, pois ela é uma consequência da relação do condutor com as outras características.

Deve ser considerada a existência de limitações no conhecimento sobre a influência das características da via nos acidentes de trânsito. Não obstante, neste trabalho foram abordadas tecnicamente informações recentes sobre a maneira em que o ambiente viário afeta a segurança da circulação. 
Os dados e informações analisados têm importância tanto para a área acadêmica, quanto para a área profissional, por envolver características das vias expressas que mais influenciam a segurança e oferecer resposta à questão 2 do trabalho: "Quais são as características físicas e operacionais ideais das rodovias e vias urbanas brasileiras?". São fundamentais a avaliação e o gerenciamento dos riscos associados aos diferentes elementos da via, pois eles podem influenciar de forma significativa as atitudes e o comportamento dos usuários e, consequentemente, a frequência e a severidade dos acidentes.

Houve limitações, tanto em questões planimétricas (curvas de transição), como em altimétricas (concordância vertical), para a obtenção dos dados da via. Apesar do método não validar o projeto geométrico da via, não permitindo identificar curvas de transição e fazendo um ajuste de todas como sendo circulares, ele não prejudica o estudo sobre estimativas das velocidades operacionais. Sendo assim, este procedimento simplificado adotando apenas tangentes e elementos circulares foi considerado como válido. As cotas da rodovia foram difíceis de serem levantadas devido à baixa precisão dos dados. Para realizar a concordância vertical, foram consideradas declividades por segmentos de alinhamentos verticais e a estimativa da flecha. Desta maneira, foi possível determinar a declividade, definida como variável independente do modelo, para cada estaca da via.

Para a análise da consistência geométrica foi utilizado o programa Saepro na previsão das velocidades operacionais. Além de ser em português, o que facilita bastante a compreensão do usuário, existem dicas e tutoriais desenvolvidos pelo próprio desenvolvedor, que auxiliam muito a sua utilização.

Não existe, ainda, um modelo proposto para previsão de acidentes a partir da análise da consistência geométrica. No entanto, os resultados deste trabalho ajudam a entender que existe uma forte relação entre o traçado da via e o índice de acidentes, uma vez que o motorista, ao perceber que vai entrar em uma curva, desacelera e, ao sair da curva, acelera, causando momentos diferenciais de velocidade. Essas percepções e reações são distintas para cada condutor, o que possibilita a formação de potenciais pontos de acidentes. Sendo assim, seria necessário um estudo com um número bem maior de estradas, avenidas e rodovias a fim de compreender o modelo de previsão de acidentes baseado no índice de consistência geométrica. 
Uma questão crucial do trabalho, que quase o inviabilizou, foi a falta de uniformidade dos bancos de dados de acidentes ocorridos nas estradas e vias urbanas na cidade do Rio de Janeiro. O modelo de preenchimento dos boletins de registros de acidentes de trânsito (BRATs) foca bastante em características de fator humano e não ajuda muito a distinção de características básicas para estudos mais complexos como, o viário e até mesmo o de entorno. Não há, nos bancos de dados, informações sobre as condições meteorológicas no momento do acidente, fundamental em estudos de drenagem ou de visibilidade.

De forma geral, todas as atividades de reconstrução e manutenção da via também são primordiais para manter o número de acidentes em níveis aceitáveis e, de preferência, nulo. Vale ressaltar que a sinalização também é um dos fatores que pode minimizar a ocorrência de acidentes e também deve ser considerada dentro das atividades de manutenção.

O estudo de caso da Autoestrada Grajaú-Jacarepaguá pode ajudar a mostrar que, a partir das análises realizadas, a infraestrutura viária é responsável pela potencialização das falhas humanas. A consistência do projeto geométrico e a questão da drenagem podem ser consideradas como as importantes características do projeto da via para se evitar a ocorrência de acidentes. Acredita-se que um projeto bem feito, que siga minuciosamente as especificações estabelecidas em normas, dificilmente irá apresentar altos índices de acidentes, como o constatado na Autoestrada Grajaú-Jacarepaguá.

São sugeridos os seguintes trabalhos para contribuir com os estudos de segurança viária:

- Análise da eficiência das intervenções viárias na redução de acidentes;

- Estudo de um modelo que relacione o índice de consistência geométrica com o número de acidentes;

- Estudo com um número maior de estradas, avenidas e rodovias, a fim de estender o banco de dados de estudos sobre as características;

- Estudo para se criar um padrão do projeto de rodovias focado na eliminação ou redução drástica do número de acidentes;

- Padronização dos bancos de dados nacionais ou, criação de um banco de dados nacional unificado, que pode ajudar na pesquisa das causas dos acidentes;

- Amplo estudo sobre as influências das características dos veículos sobre os acidentes. 


\section{REFERÊNCIAS BIBLIOGRÁFICAS}

AASHTO - American Association of State Highway and Transportation Officials. Highway safety design and operations guide. Washington D.C., EUA, 1997.

. A policy on geometric design of highways and streets. Washington D.C., EUA, 2001. p. 247-259.

ALE, B. Risk assessment practices in The Netherlands. In: Safety Science. vol. 40, n. 1-4, 2002.p.105-126.

ALERTA RIO, 2016. Relatório anual de chuva para a cidade do Rio de Janeiro no ano de 2015. Relatório GEO-RIO/DEP/GPE - N. ${ }^{\circ}$ 001/2016. Disponível em: $<$ http://alertario.rio.rj.gov.br/wp-content/uploads/2016/08/rel2015.pdf $>$. Acesso em: Dezembro de 2016.

ARBAIZA, A. e LUCAS, A. Cuestiones Actuales sobre Mensajería Variable: una Propuesta de Desarrollo. In: VI Congreso de Ingeniería del Transporte. Zaragoza, Espanha, 2004.

ARCOWEB; JBMC. Arquitetura e urbanismo: Passarela e estação, Rio de Janeiro. Disponível em: <https://arcoweb.com.br/projetodesign/arquitetura/jbmc-arquiteturaurbanismo-passarela-estacao-14-12-2011>. Acesso em: Novembro de 2016.

ASF - Automotive Safety Foundation. Traffic control and roadway elements. Their relationship to highway safety. Technical Report, EUA, 1963. Disponível em: $<$ https://trid.trb.org/view.aspx?id=112840>. Acesso em: Janeiro de 2015.

A TRIBUNA. Desnível no asfalto prejudica munícipes de Santos. Disponível em: $<$ http://blogs.atribuna.com.br/quemresolve/2014/09/desnivel-no-asfalto-prejudicamunicipes-de-santos/>. Acesso em: Novembro de 2016.

BAKER, R. Handbook of Highway Engineering. EUA: Van Nostrand Reinhold Company, 1975.

BERNUCCI, L. B; MOTTA, L. M. G.; CERATTI, J. A. P.; SOARES, J. B. Pavimentação asfáltica: Formação básica para engenheiros. $1^{\text {a }}$ Edição. Rio de Janeiro: Petrobras/Abeda, 2007. 
BRAGA, M; RIBEIRO, S. e FERREIRA, M. Envolvimento em acidentes e exposição ao tráfego: Estudo de caso para a cidade do Rio de Janeiro. Rio de Janeiro: III Rio de Transportes, 2005.

BRIGIDO, M. R. A Estrada Grajaú-Jacarepaguá. In: Revista Municipal de Engenharia. vol. XVII, 1950. p. 86.

CARLSON, D. e STOUT, D. Stack emissions with asphalt rubber a synthesis of studies. Brasília: Asphalt Rubber, 2003.

CET-Rio - Companhia de Engenharia de Tráfego da cidade do Rio de Janeiro. Análise dos pontos de acidentes - Avenida Menezes Cortes - Grajaú Jacarepaguá. Rio de Janeiro, 2012.

CETRA - Centro de Investigación y Desarrollo del Transporte. Seguridad en vías de interés nacional. Incidencia de la infraestructura viaria. Ministerio del Transporte. Havana, Cuba, 2003.

CEPIS - Centro Panamericano de Ingeniería Sanitária y Ciencias del Ambiente. Risk perception. Organização Panamericana da Saúde. Disponível em: $<$ http://www.cepis.ops-oms.org/tutorial6/i/pdf/topic_04.pdf $>$._ Acesso em: Setembro de 2015.

CFIA - Canadian Food Inspection Agency. Communication and Government; Theory and Application for the Canadian Food Inspection Agency (CFIA). Disponível em: $<$ http://www.inspection.gc.ca/english/corpaffr/publications/riscomm/riscomme.shtml $>$. Acesso em: Setembro de 2015.

CHU, X. Measuring the risk of walking. Canadá: XVII Entretiens du Centre Jacque Cartier. Transports en commun et Transports routiers urbains: qui doit payer?, 2004.

CNT - Confederação Nacional do Transporte. Relatório Gerencial - Pesquisa Rodoviária. Brasília, 2016. Disponível em: < http://pesquisarodovias.cnt.org.br/Paginas/relatoriogerencial>. Acesso em: Dezembro de 2016.

COMISSÃO EUROPEIA. Programa de Ação Europeu: Reduzir para metade o número de vítimas da estrada na União Européia até 2010, uma responsabilidade de todos. 
Bruxelas, Bélgica, 2003. Disponível em: <http://europa.eu.int/comm/transport/ road/ library/rsap/com_2003_0311_pt.pdf $>$. Acesso em: Setembro de 2015.

CONTRAN - Conselho Nacional de Trânsito. Manual brasileiro de sinalização de trânsito: Volume IV - Sinalização Horizontal. 1ª Edição. Brasília: CONTRAN, 2007.

COWELL, S., FAIRMAN, R. e LOFSTEDT, K. Use of risk assessment and life cycle assessment in decision making: A common policy research agenda. In: Risk Analysis. vol. 22, n. 5, 2002. p. 879-894.

DENATRAN. Departamento Nacional de Trânsito. Disponível em: $<$ http://www.denatran.gov.br>. Acesso em: abril de 2015.

DIÓGENES, M. Método para avaliar o risco potencial de atropelamentos em travessias urbanas em meio de quadra. Tese (Doutorado). Porto Alegre: Universidade Federal do Rio Grande do Sul, 2008.

DNER - Departamento Nacional de Estradas de Rodagem. Manual inter-americano de sinalização rodoviária e urbana. Rio de Janeiro: Instituto de Pesquisas Rodoviárias Ministério dos Transportes, 1971.

. Manual de projeto geométrico de rodovias rurais. Rio de Janeiro: Instituto de Pesquisas Rodoviárias, Ministério dos Transportes, 1999.

DNIT - Departamento Nacional de Infraestrutura de Transportes. Manual de projeto de interseções. Rio de Janeiro: Publicação IPR - 718, Ministério dos Transportes, 2005. . Manual de vegetação rodoviária: Implantação e recuperação de revestimentos vegetais rodoviários. Rio de Janeiro: Publicação IPR - 734, Ministério dos Transportes, 2009.

- Manual de projeto geométrico de travessias urbanas. Rio de Janeiro: Publicação IPR - 740, Ministério dos Transportes, 2010a.

. Manual de sinalização rodoviária. Rio de Janeiro: Publicação IPR - 743, Ministério dos Transportes, 2010b. 
ETSC - European Transport Safety Council. German Autobahn: The Speed Limit Debate, Speed Fact Speed 1. Disponível em: <http://www.etsc.eu/documents /copy_of_Speed\%20Fact\%20Sheet\%201.pdf>. Acesso em: Setembro de 2015.

EWING, R. e DUMBAUGH, E. The Built Environment and Traffic Safety: Review of Empirical Evidence. In: Journal of Planning Literature. vol. 23, n. 4. p. 47-367.

FARIA, E. e BRAGA, M. Condições necessárias e objetivos da educação para o trânsito desde o ponto de vista dos profissionais brasileiros. Nova Iorque: XIII Congresso Panamericano de Engenharia de Trânsito e Transporte. Disponível em: $<$ http://www.transitocomvida.ufrj.br/download/Condi\%C3\%A7\%C3\%B5es\%20necess\%C3 \%A1rias\%20e\%20objetivos\%20da\%20educ.pdf>. Acesso em: Setembro de 2015.

FHWA - Federal Highway Administration. Safety effectiveness of highway design features - volume III: Cross sections. In: Publication No. FH WA-RD-91-046, 1992.

. Prediction of the Expected Safety Performance of Rural Two-Lane Highways. In: Publication No. FHWA-RD-99-207, 2000. Disponível em: <http://www.fhwa.dot.gov/ publications/research/safety/99207/99207.pdf>. Acesso em: Junho de 2015.

. Evaluation of Design Consistency Methods for Two-Lane Rural Highways, Executive Summary. In: Publication FHWA-RD-99- 173(25):1-25, 2000.

. National Review of the Highway Safety Improvement Program. U.S. Department of Transportation, 2001. Disponível em: <http://safety.fhwa.dot.gov/state_program/ hsip/hsip_final.html>. Acesso em: Setembro de 2015.

. Freeway Management and Operations Handbook. In: Publication No. FHWA-OP04-003, 2003. Disponível em: <http://ops.fhwa.dot.gov/freewaymgmt/publications/ frwy_mgmt_handbook/fmoh_complete_all.pdf>. Acesso em: Julho de 2015.

. Vegetation control for safety, a guide for local highway and street maintenance personnel. In: Publication No. FHWA-SA-07-018, 2008a. Disponível em: $<$ http://safety.fhwa.dot.gov/local_rural/training/fhwasa07018/>. Acesso em: Setembro de 2015. 
. Effect of increases in speed limits on severities of injuries in accidents. In: Publication No. FHWA-AS-09-028, 2008b. Disponível em: $<$ http://safety.fhwa.dot.gov/speedmgt/ref_mats/fhwasa09028/resources/Effect\%20of\%20Incr eases\%20in\%20Speed\%20Limit.pdf>. Acesso em: Setembro de 2015.

FOI UM RIO QUE PASSOU. Grajaú-Jacarepaguá I. 2005. Disponível em: $<\mathrm{http}: / / w w w . r i o q u e p a s s o u . c o m . b r / 2005 / 11 / 16 /$ grajau-jacarepagua-i/>. Acesso em: Novembro de 2016.

FRAMARIM, C. Procedimento para monitorar medidas voltadas à redução dos acidentes no sistema viário. Dissertação (Mestrado). Porto Alegre: Universidade Federal do Rio Grande do Sul, 2003.

G1. Carro pega fogo e interdita Grajaú-Jacarepaguá, sentido Zona Oeste. 2012. Disponível em: <http://g1.globo.com/rio-de-janeiro/noticia/2012/12/carro-pega-fogo-e-interditagrajau-jacarepagua-sentido-zona-oeste.html>. Acesso em: Setembro de 2015.

GAO - General Accounting Office. Research Continues on the Variety of Factors That Contribute to Motor Vehicle Crashes. In: Report to Congressional Requesters No. GAO-03-436, 2003. Disponível em: <http://www.gao.gov/new.items/d03436.pdf>. Acesso em: Junho de 2015.

GARCIA, D. S. P. Método para análise da consistência geométrica de rodovias brasileiras de pista simples. Tese (Doutorado). Porto Alegre: Universidade Federal do Rio Grande do Sul, 2008.

. Diretrizes para o desenvolvimento de um sistema avançado para estudos e projetos viários: o conceito BIM no projeto de obras de infraestrutura. Espanha: Congresso Panamericano de Inginiería de Tránsito, Transporte y Logística. Santander, 2014.

GOLD, P. A. Segurança de trânsito: Aplicações de engenharia para reduzir acidentes. EUA: BID - Banco Interamericano de Desenvolvimento, 1998.

GOOGLE MAPS. Imagens. Disponível em: <https://www.google.com.br/maps>. Acesso em: Novembro de 2015. 
GRSP - Global Road Safety Partnership. Speed management: a road safety manual for decision-makers and practitioners. Geneva, Switzerland, 2008.

HOJE EM DIA. Aquaplanagem: a única prevenção é rodar em baixa velocidade na pista molhada, 2015. Disponível em: <http://hoje.vc/e55j>. Acesso em: Novembro de 2016.

IHSDM - Interactive Highway Safety Design Model. IHSDM Documents e IHSDM Tutorial, 2006.

IMT - Instituto Mexicano del Transporte. Algunas consideraciones de segurida para el proyecto geométrico de carreteras. In: Publicación Técnica No. 217, Secretaría de Comunicaciones y Transportes, Sanfandila, México, 2002. Disponível em: $<$ http://www.imt.mx/archivos/Publicaciones/PublicacionTecnica/pt217.pdf.>. Acesso em: Setembro de 2015.

INMET - Instituto Nacional de Metereologia. Número de dias com precipitação maior ou igual a $1 \mathrm{~mm}$ (dias), 2014. Disponível em: <http://www.webcitation.org/ 6PKYY8S3U>. Acesso em: Dezembro de 2016.

JC ONLINE. Motociclistas ficam feridos após derrapagem em pista com óleo, em Olinda, 2015. Disponível em: <http://jconline.ne10.uol.com.br/canal/cidades/jc-transito/ noticia/2015/10/15/motociclistas-ficam-feridos-apos-derrapagem-em-pista-comoleo-em-olinda-203698.php>.. Acesso em: Novembro de 2016.

KHISTY, J. e LALL, K. Transportation engineering an introduction. Nova Jersey: PrenticeHall Inc, 1998.

KOLISETTY, V. G. B.; IRYO, T; ASAKURA, Y. Effect of variable message signs on driver speed behavior under fog conditions. In: Journal of Advanced Transportation, 2006. p. $47-74$.

LAMM, R.; CHOUEIRI, E. M.; HAYWARD, J. C.; PALURI, A. Possible design procedure to promote design consistency in highway geometric design on two-lane rural roads. In: Transportation research record 1195. Washington: National Research Council, 1988. p. 111-122. 
; CHOUEIRI, E. M.; MAILAENDER, T. Comparison of operating speed on dry and wet pavement of two lane rural highways. In: Transportation Research Record 1280, 1990. p. 199-207.

; GUENTHER, A. K. . Safety module for highway geometric design. In: Transportation Research Record 1512, 1995, p. 7-15.

; PSARIANOS, B.; MAILAENDER, T. Highway design and traffic safety engineering handbook. McGraw-Hill, 1999. p. 9.1-9.76.

MAGNOLI, D. e ARAÚJO, R. Geografia - A construção do mundo, geografia geral e do Brasil. São Paulo: Editora Moderna, 2005.

MAIA, J. Uma análise sistêmica dos acidentes de trânsito no Brasil. Dissertação (Mestrado). João Pessoa: Universidade Federal da Paraíba, 1995.

MT - Ministério dos Transportes. Programa de redução de acidentes no trânsito, 2013. Disponível em: <http://www.transportes.gov.br/>. Acesso em: Abril em 2015.

NCHRP - National Cooperative Highway Research Program. Recommended procedures for the safety performance evaluation of highway features. In: NCHRP Report 350. Transportation Research Board of the National Academies. 1993. EUA. Disponível em: <http://gulliver.trb.org/publications/nchrp/nchrp_rpt_350-a.pdf>. Acesso em: Agosto de 2015.

- Strategies for improving roadside safety. In: Research Results Digest 220. Transportation Research Board of the National Academies, 1997.

. Performance of Roadside Barriers. In: NCHRP Project 22-13. Transportation Research Board of the National Academies, 1999. Disponível em: $<$ http://apps.trb.org/cmsfeed/

TRBNetProjectDisplay.asp?ProjectID=684>. Acesso em: Outubro de 2015.

. Methodology to predict the safety performance of urban and suburban arterials. In: NCHRP Project 17-26. Transportation Research Board of the National Academies, 2007. 
NODARI, C. Método de avaliação da segurança potencial de segmentos rodoviários rurais de pista simples. Tese (Doutorado). Porto Alegre: Universidade Federal do Rio Grande do Sul, 2003, RS.

. e LINDAU, L. Auditorias de segurança viária. In: Transportes. vol. 9, n. 2, 2001.p 48-66.

. e . Método de avaliação da segurança potencial de segmentos rodoviários rurais de pista simples. Nova Iorque: XIII Congresso Panamericano de Engenharia de Trânsito e Transporte, 2004.

NOLAND, R. B. Traffic fatalities and injuries: the effect of changes in infrastructure and other trends. In: Accident Analysis and Prevention. vol. 35, n. 4, 2003. p. 599-611.

NORMA, N. Luz para salvar vidas. In: Tráfico. n. 168, 2004. p. 29-32.

O GLOBO. Internautas registram carro da polícia estacionado irregularmente na Tijuca, Zona Norte do Rio, 2009. Disponível em: <http://oglobo.globo.com/participe/mat/ 2009/12/19/internautas-registram-carro-da-policia-estacionado-irregularmente-natijuca-zona-norte-do-rio-915290449.asp.>. _Acesso em: Setembro de 2014.

OGDEN, K. W. Safer roads: a guide to road safety engineering. Ashgate Publishing limited, Cambridge: University Press, Cambridge, 1996.

. The effects of paved shoulders on accident on rural highwyas. In: Accident Analysis and prevention. vol. 9, n. 3, 1997. p. 353-362.

OWERS, R. e WILSON, E. Safety analysis without the legal paralysis: The Road Safety Audit. Wyoming: University of Wyoming, 2001. Disponível em: $<$ http://www.mountain-plains.org/pubs/pdf/MPC02-129.pdf $>$. Acesso em: Outubro de 2015.

PARK, B., FITZPATRICK, K. e LORD, D. Evaluating the Effects of Freeway Design Elements on Safety. Washington DC: 89th Transportation Research Board (TRB) Annual Meeting, 2010. 
PARKIN, R. e BALBUS, J. Variations in concepts of “susceptibility in risk assessment”. In: Risk Analysis. vol. 20, n. 5, 2000. p. 603-612.

PARQUE NACIONAL DA TIJUCA. Mapa turístico. Rio de Janeiro, 2011.

PDTU 2011- Plano Diretor de Transporte Urbano do Rio de Janeiro. Atualização do Plano Diretor de Transporte Urbano da Região Metropolitana do Rio de Janeiro. Relatório 4. Atividade 6.4 - Pesquisas de origem e destino - Parte 2. Aspectos da realização das pesquisas de campo domiciliar e interceptação, 2013. Disponível em: $<$ http://download.rj.gov.br/documentos/10112/1694464/DLFE-62312.pdf/Resultados dasPesquisasDomiciliaresedeInterceptacao.pdf $>$. Acesso em: Setembro de 2015.

PEÑA, E. Las Carreteras y la Noche. Ver y Ser Visto. Espanha: VI Congreso de Ingeniería del Transporte, 2004.

PEREIRA, L. Um procedimento de apoio à decisão para escolha de sistemas de controle de tráfego considerando a coleta automatizada de dados. Dissertação (Mestrado). Rio de Janeiro: Instituto Militar de Engenharia, 2005.

PICADO, J. La Ingeniería de Tránsito y la Gestión de Seguridad Vial. Manual. San José, Costa Rica, 2005.

RENN, O. The role of risk perception for risk management. In: Reliability Engineering and System Safety. n. 59, 1998. p. 49-62.

RIO. CET-Rio monitora Estrada Grajaú-Jacarepaguá. Disponível em: $<$ http://www.rio.rj.gov.br/web/guest/exibeconteudo?article-id=1842079>. Acesso em: novembro de 2016.

RBS - Real Brás Sinalização Viária. Sinalização Vertical. Disponível em: $<$ http://www.rbs.eng.br/sinalizacao-vertical>. Acesso em novembro de 2016.

RODRIGUE, J; COMTOIS, C. e SLACK, B. The geography of transport systems. New York: Hofstra University. Disponível em: <http:/geonas.at.ua/_ld/0/ 34_The_Geography_o.pdf $>$. Acesso em setembro de 2015. 
SAMPEDRO, A. e FOGLIATTI, C. Estratégias atuais visando a segurança viária. In: Revista Militar de Ciência e Tecnologia. vol. XXIII, 2005. p. 77-83.

- Procedimento para avaliação da segurança de tráfego em vias urbanas. Dissertação (Mestrado). Rio de Janeiro: Instituto Militar de Engenharia, Rio de Janeiro, 2006.

. Procedimento para avaliação e análise da segurança de tráfego em vias expressas urbanas. Tese (Doutorado). Rio de Janeiro: UFRJ/COPPE, 2010.

SÁNCHEZ, J. El riesgo de correr. In: Tráfico. n. 150, 2001. p. 25-26.

SCHELB. 70's - Spray. Disponível em: <https://rafaelschelb.wordpress.com/2012/08/ 30/70s-spray/>. Acesso em: Novembro de 2016.

SCHLECHTER, W. Process risk assessment - Using science to "do it right". In: International Journal of Pressure Vessels and Piping. n. 61, 1995. p. 479-494.

SENÇO, W. Manual de técnicas de projetos rodoviários. São Paulo: Escola Politécnica da USP, 1997.

SHANKAR, V.; MANNERING, F.; BARFIELD, W. Effect of roadway geometric and enviromental factors on rural freeway accident frequencies. In: Accident Analysis and Prevention. vol. 27, n. 3, 1995. p. 371-389.

SMTR - Secretaria Municipal de Transportes. Apresentação GIT: Gerência de Informações de Tráfego. Rio de Janeiro: Seminário Acidentes de Trânsito no Município do Rio de Janeiro. Rio de Janeiro, 2012.

TEDESCO, T. Avaliação do uso de guias sonoras como medida de redução de acidentes nas rodovias de Rio Grande do Sul. Dissertação (Mestrado). Porto Alegre: Universidade Federal do Rio Grande do Sul, 2004.

TRAFFIX DEVICES. Scorpion ${ }^{\circledR}$ Trailer Attenuator. Disponível em: $<$ https://www.traffixdevices.com/products/attenuators/scorpion-trailer $>$. Acesso em: Novembro de 2016. 
TRÂNSITO EM FOCO. Rotatórias - Parte I (Conceito e vantagens). Disponível em: $<$ https://transitoemfoco.wordpress.com/2011/04/04/rotatorias-parte-i-conceitos-evantagens/>. Acesso em: Novembro de 2016.

. Entendendo as placas de proibição de estacionamento composta (Início e término). Disponível em: <https://transitoemfoco.wordpress.com/2009/12/10/entendendo-as-placasde-regulamentacao-de-estacionamento/>. Acesso em: Novembro de 2016.

TRB - Transportation Research Board of the National Academies. Designing safer roads: practices for resurfacing, restoration and rehabilitation. In: Special Report. n. 214, 1987.

.Managing Speed. Review of Current Practice for Setting and Enforcing Speed Limits. In: Special Report. n. 254, 1998.

. Strategic plan for improving roadside safety. In: NCHRP web document 33. n. G17-

13. Washington D.C.: National Research Council, 2001.

. Development of the Highway Safety Manual. In: NCHRP Web Document 62 (Project 17-18[4]): Contractor's Final Report. EUA: National Cooperative Highway Research Program, 2004.

TREEHUGHER. Solar Powered LEDs Light Up Highways. Disponível em: $<$ http://www.treehugger.com/solar-technology/solar-powered-leds-light-up-highways .html>. Acesso em: Novembro de 2016

TXDOT - Texas Department of Transportation. Access Management Manual. Texas, EUA, 2004. Disponível em: <http://www.accessmanagement.info/pdf/Texas_acm .pdf>. Acesso em: Agosto de 2015.

VADEONIBUS. Artigo. Disponível em: <http://www.vadeonibus.com.br/Vdo/index.php.>. Acesso em: Novembro de 2016.

VEJA-SP. Lei Cidade Limpa perde força em São Paulo. Disponível em: $<$ http://vejasp.abril.com.br/materia/lei-cidade-limpa-perde-forca-em-sao-paulo $>$. Acesso em: Novembro de 2016. 
WAISELFISZ, J. Mapa da violência 2014 - Os jovens do Brasil: Acidentes de trânsito. Rio de Janeiro: Flacso Brasil, 2014

WALTHER, E. S. Ruralization of Risk Management: A Handbook for Small Transit Operators, U. S. Department of Transportation, 1992.

WETTON, M.; HORSWILL, M.; HATHERLY, C.; WOOD, J.; PACHANA, N. e ANSTEY, $\mathrm{K}$. The development and validation of two complementary measures of drivers "hazard perception ability". In: Accident Analysis and Prevention. vol. 42, n. 4, 2010. p. 12321239 .

WHO - World Health Organization. Global status report on road safety: Time for action. Suiça: Organização das Nações Unidas, 2009.

. Global status report on road safety: Time for action, Suiça: Organização das Nações Unidas, 2013. 